\author{
UNIVERSIDADE DE SÃO PAULO \\ INSTITUTO DE FÍSICA \\ INSTITUTO DE QUÍMICA \\ INSTITUTO DE BIOCIÊNCIAS \\ FACULDADE DE EDUCAÇÃO
}

ESDRAS VIGgIANO DE SOUZA

\title{
UMA PROPOSTA DE LEVANTAMENTO DE PERFIS \\ CONCEITUAIS DE ENSINAR E APRENDER
}

SÃo PaUlo

2008 


\author{
ESDRAS VIGgIANO DE SOUZA
}

\title{
UMA PROPOSTA DE LEVANTAMENTO DE PERFIS CONCEITUAIS DE ENSINAR E APRENDER
}

\author{
Dissertação de Mestrado apresentada à Comissão do \\ Programa de Pós-Graduação Interunidades em Ensino \\ de Ciências da Universidade de São Paulo, como \\ requisito para obtenção do título de Mestre em Ensino \\ de Ciências.
}

Área de concentração: Ensino de Física.

Orientador: Prof. Dr. Cristiano Rodrigues de Mattos

Banca Examinadora:

Prof. Dr. Cristiano Rodrigues de Mattos (IF-USP - Orientador / Presidente)

Prof. Dr. Alberto Villani (IF-USP - Membro interno)

Prof. Dr. Orlando Gomes de Aguiar Jr. (UFMG - Membro externo)

\section{SÃo PaUlo}


AUTORIZO A REPRODUÇÃO PARCIAL DESTE TRABALHO, PARA FINS DE ESTUDO E PESQUISA, DESDE QUE CITADA A FONTE. A REPRODUÇÃO COMERCIAL, EM TODO OU EM PARTE, POR QUALQUER MEIO, SOMENTE É PERMITIDA COM EXPRESSA AUTORIZAÇÃO ESCRITA DO AUTOR.

FICHA CATALOGRÁFICA
Preparada pelo Serviço de Biblioteca e Informação
do Instituto de Física da Universidade de São Paulo
\begin{tabular}{|l} 
Souza, Esdras Viggiano de \\
"Uma proposta de levantamento de perfis conceituais de \\
ensinar e aprender" - São Paulo - 2008 \\
Dissertação (Mestrado) - Universidade de São Paulo. \\
Instituto de Física. Departamento de Física Experimental \\
Orientador: Prof. Dr. Cristiano Rodrigues de Mattos \\
Área de Concentração: Ensino de Ciências \\
Unitermos: 1. Ensino e aprendizagem; 2. Associações \\
contextuais; 3. Formação de professores; 4. Ensino de física, 5. \\
Perfil conceitual \\
USP/IF/SBI-058/2008
\end{tabular}


Dedico este trabalho a minha mãe, à minha irmãzinha Gaia, à $\mathrm{Lu}$ e àqueles que compartilharam o aprendizado do caminho. 


\section{AGRADECIMENTOS}

Agradecer é necessário, indispensável. Isto porque, a aprender somente é possível se as condições culturais e sociais o possibilitam, se a intersubjetividade cotidiana permite o aprendizado. Agradeço o aprendizado que tive com cada uma das pessoas que passaram em meu caminho, sei que é, sem dúvida, impossível nominalizar todos que contribuíram, por isso destacarei apenas algumas pessoas, mas meu coração não deixa as outras serem esquecidas. Portanto agradeço:

À banca de defesa pelo trabalho de leitura e crítica.

À banca da qualificação, Prof. Alberto Villani e Prof. Marcelo Giordan, pela discussão produtiva e crítica, que sem dúvida levou à evolução do trabalho.

Ao Cristiano, com quem aprendi coisas que pouco orientadores são capazes de ensinar, e também pela torcida no estabelecimento em São Paulo. Pelo aprendido em reuniões, viagens, cafés, almoços etc. Ensinou-me que uma pergunta vital é indispensável para se levar uma pesquisa e mesmo a vida e que é possível ser feliz, sempre que nos empenhamos em algo que gostamos. Por vezes, entramos em discussões longuíssimas, que não terminaram, e provavelmente, nunca terminarão, o que acabou culminando na atual versão do texto. Realmente, muito obrigado Cristiano.

Ao Prof. José Guilherme Moreira, que me permitiu desenvolver as atividades de iniciação científicas, fornecendo-me subsídios de pesquisa e que era possível realizar pesquisa em Ensino de Física no Brasil, mesmo que em contextos por demais hostis. 
Aos professores Silvania Nascimento, Orlando Aguiar e Maria Emília que incentivaram a realização do mestrado em Ensino de Física, contribuindo para meu conhecimento na área.

À professora Maria Regina, mãe dos alunos da pós, pelo incentivo, socorros oportunos, ajudas nos conteúdos de Física e de Educação, pelo exemplo de garra, determinação e motivação, sempre presente com um ombro amigo, nunca me deixando desanimar.

Agradeço aos colegas e amigos do grupo ECCo, que por diversas vezes criticaram o trabalho, se envolveram em discussões, tanto nas reuniões quanto nos cafés acadêmicos.

Aos funcionários Camila, Leonardo, Ellen, Francislaine e Thomas pelo atencioso atendimento. Ao Ailton e a Darci pela colaboração constante.

À Adrilayne, tanto pela amizade quanto pela ajuda estatística.

Às amigas Luciana e Marcília pelas parcerias. Aos amigos Renatinha, Cristina, Ivã, Anne, Fábio, Lígia e Soninha, pelo bom incentivo

Aos meus amigos especiais Glauco, Thaís Alencar, Soraya, Francisco, Jacke e Giselle que por vezes não me deixaram desanimar e me deram força para seguir o caminho firmemente, sempre com palavras de apoio e profundo respeito.

À Sylvia pelo bom ânimo, infinitos conselhos, ponderações, por ser uma comparsa nas coisas que transcendem a vida. À Thaís Forato pelo grande coração e exemplo de pessoa dedicada. À Rose, pessoa importante principalmente na reta final, sempre escutando a angústia e tranqüilizando o coração, lembrando que dias melhores virão. 
Ao Fred pela forte amizade, nos grandes e nos pequenos momentos, nos rápidos e intensos e nos lentos e delicados como na escrita deste trabalho. $\mathrm{E}$ também pelo companheirismo e força na concretização de um sonho de infância, o GP Brasil de Fórmula 1.

Ao Breno, que apesar de não ter o mesmo sangue, faz parte de minha família espiritual. Acompanhou praticamente cada palavra deste texto, cada momento de felicidade e tristeza, apoiou minhas decisões, aconselhou o coração, contribuindo de forma inestimável para este trabalho e para eu ser quem sou.

Ao meu pai e à Mônica pela torcida e colaboração. Às minhas tias Vânia, Lãnia e Sânia e minha vó Cacilda, que me ensinaram que a "vida é bonita, é bonita e é bonita". Ao meu tio Roque, aos meus primos Léo e Rominho e primas Branca, Pretinha e Camila pelo carinho e incentivo. À Lara pelo amor, simplicidade e pela felicidade que me trás sempre.

Agradeço aos meus irmãos Eros e Deimos pela torcida e incentivo permanente, por estarem sempre presentes, quando precisei ou não e também pelos excelentes momentos que passamos juntos.

Agradeço a minha manzinha Gaia pela palavra amiga, por ter sido minha comparsa e confidente essencial, por ser força motriz de meu coração.

À Aparecida, Antônio e Tati por terem me acolhido tão bem na família, acompanhando e incentivando o trabalho.

À $\mathrm{Lu}$, que me incentivou a tentar o mestrado. Que é o verdadeiro anjo encarnado, pelo carinho, pelo amor incondicional, por ser o ar que respiro. E por ser, sem dúvida, pessoa indispensável à minha felicidade. 
Ao meu beija-flor, meu maior exemplo, minha mãe. Que mostrou que tudo é superável, mesmo as maiores perdas, mesmo as mais intensas saudades, desde que tenhamos amor incondicional pelo outro. Ensinou-me que a Educação é o maior bem que temos depois do amor. Foi meu exemplo de trabalho, dedicação, determinação...

À CAPES pela bolsa fornecida.

E principalmente aos alunos da licenciatura em Física, que forneceram tão importantes dados para a realização desta pesquisa.

A todos aqueles que teceram relações na minha malha de conhecimentos, muito obrigado! 
"Se a transparência da inteligibilidade estivesse garantida, destruiria o texto, mostraria que não tem porvir, que não transborda o presente, que se consuma imediatamente; portanto, uma certa zona de desconhecimento e de incompreensão é também uma reserva e uma possibilidade excessiva - uma possibilidade para o excesso de se ter um futuro e de, por conseguinte, se gerarem novos contextos. Se todos podem entender imediatamente o que quero dizer, não criei contexto algum, respondi mecanicamente à expectativa, e está tudo onde está, ainda que as pessoas aplaudam e leiam até com prazer. Depois fecham o livro, e acabou-se"

Jacques Derrida 


\section{RESUMO}

SOUZA, Esdras Viggiano Uma proposta de Levantamento de perfis conceituais de ensinar e aprender. 2008. 250 f. Dissertação (Mestrado em Ensino de Ciências Ensino de Física) - Instituto de Física, Faculdade de Educação, Universidade de São Paulo, São Paulo, 2008.

A noção de perfil conceitual nos permite conceber que um conceito pode ser representado de diversas maneiras, as quais são chamadas de zonas do perfil conceitual. Cada conceito é utilizado a partir dos contextos estabelecidos na interação humana. Nesta direção, nos propomos realizar o levantamento dos perfis conceituais de ensinar e de aprender de licenciandos em Física, procurando estabelecer a relação entre estes perfis. Para tanto, construímos um questionário com questões que fornecessem marcas de delineamento de contextos, de forma a procurar identificar o uso das zonas de perfil conceitual em cada um desses. O Referencial Teórico foi constituído a partir ampliação da noção de perfil conceitual proposta por Mortimer (1995), nas idéias de Bernstein (1996) sobre contexto e significado, nos estudos sobre conceitos na psicologia da aprendizagem e de algumas considerações baseadas na psicologia histórico-cultural. Estabelecemos categorias, relacionadas a ensinar e a aprender, que foram utilizadas na construção e análise do questionário. Estabelecemos relações entre as respostas referentes ao questionário com ênfase na categoria Concepções de Educação para investigar a constituição dos perfis conceituais de ensinar e de aprender e a relação destas, que hipoteticamente ocorre em um perfil conceitual de ensinar-aprender.

Palavras-chave: Perfil conceitual, contextos, ensinar, aprender, ensinar-aprender. 


\section{ABSTRACT}

SOUZA, Esdras Viggiano A proposal of conceptual profiles assessment of 'to learn' and 'to teach'. 2008. $250 \mathrm{f}$. Dissertation (Master in Science Education - Physics Education) - Physics Institute, Education Faculty, University of São Paulo, São Paulo, 2008.

The notion of conceptual profile allows us to conceive that a concept could be represented in several different ways, which are called zones of the conceptual profile. Each concept is used in contexts established in human interactions. Then, we propose to assess the conceptual profile of "to teach" and "to learn" of the pre-service Physics teachers, trying to relate those conceptual profiles. To achieve this target we build a questionnaire with questions that address contexts of concept's use, trying to identify which conceptual profile zone is used in the specific situation. The theoretical referential was weaved with the amplified notion of Mortimer's original proposal of conceptual profile (1995), with Bernstein's ideas about meaning and context, with studies about concept of the Psychology of learning and with some considerations based on the cultural-historic psychology. We proposed categories related with the two concepts "to teach" and "to learn" that were used to built and to analyze data. Data were related through the category of Concepts of Education to research the existence of those conceptual profiles and if there is a more complex conceptual profile of "teachinglearning".

Keywords: Conceptual profile, contexts, to learn, to teach, teaching-learning, training teachers. 


\section{SUMÁRIO}

RESUMO

ABSTRACT

INTRODUÇÃO

CAPÍTULO 1:REFERENCIAL TEÓRICO.

1.1. Concepções alternativas e mudança conceitual .....................................................................................26

1.2. $\quad$ A Noção de Perfil Conceitual ..............................................................................................................32

1.2.1. A noção de perfil conceitual proposta por Mortimer.......................................................................32

1.2.2. Trabalhos utilizando perfil conceitual ...................................................................................................34

1.3. Um Perfil Conceitual Complexo …………............................................................................................38

1.3.1. Conceitos .........................................................................................................................................40

1.3.2. Perfil Conceitual Complexo ....................................................................................................................44

1.3.3. Significados, Contextos e Educação......................................................................................................46

1.3.4. Relação do Perfil Conceitual e Contexto ..................................................................................................55

1.3.5. Algumas considerações: Perfis conceituais e teoria histórico-cultural ..............................................59

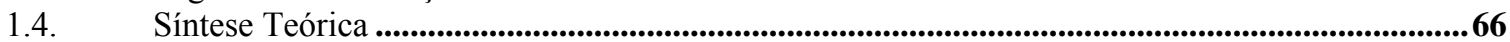

CAPÍTULO 2:PROBLEMA DE PESQUISA.............................................................................69

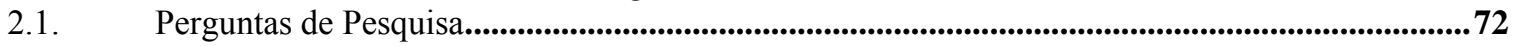

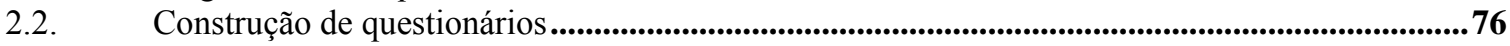

2.3. Questionários para medição de perfis conceituais ........................................................................79

CAPÍTULO 3: ENSINAR E APRENDER................................................................................ 83

3.1. Concepções de Educação....................................................................................................................84

3.1.1. Algumas visões de Educação na literatura de Ensino de Ciências .....................................................85

3.1.2. Algumas visões de interação entre pares ...........................................................................................100

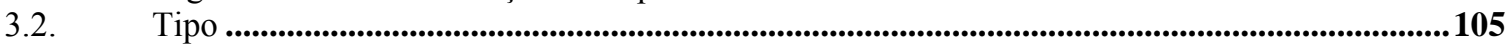

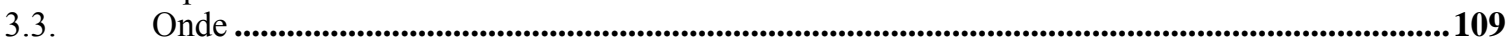

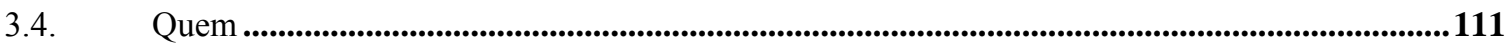

3.5. Supervisão .................................................................................................................112

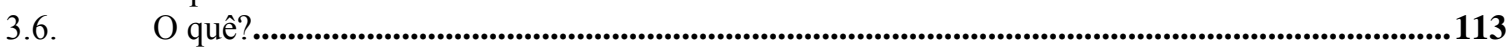

3.7. Por quê / Para quê? .........................................................................................................................114

3.8. Considerações.........................................................................................................................114

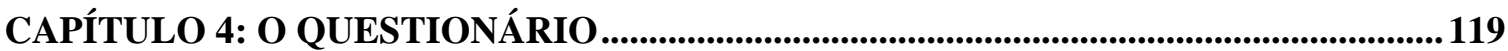

4.1. A construção........................................................................................................................................120

4.1.1. Tabulação e Categorização dos Dados ..................................................................................................125

4.1.2. Caracterização da Amostra e Aplicação do questionário ...................................................................129

4.2. Análise dos dados ...........................................................................................................................137

4.2.1. Comparação dos modelo de questionários.............................................................................................142

4.2.2. Correlações entre as categorias......................................................................................144

4.2.3. Análise das questões Q01A (O que é aprender?) e Q04A (Como se aprende fora da escola?)..146

4.2.4. Análise das questões "Como se aprende fora da escola?" (Q04A) e "De que forma se colocar na posição do outro ajuda a aprender?" (Q09A) .................................................................................................152

4.2.5. Análise das questões "Como se aprende?" (Q03A) e "Como se aprende com a televisão na

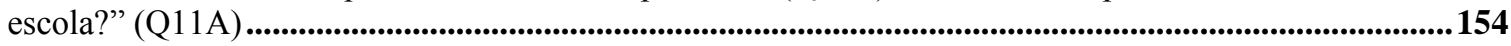

4.2.6. Análise das questões "De quais formas podemos aprender com um colega na escola?" (Q07A)

e "Como se aprende com a televisão na escola?" (Q11A) ..............................................................................158

4.2.7. Análise das questões "O que é aprender?" (Q01A) e "Como se ensina física mal?" (Q19E) ....161

4.2.8. Análise das questões "Como se aprende fora da escola?" (Q04A) e "Como se ensina física

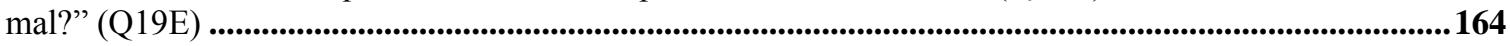

4.2.9. Análise dos pares de questões Q04A-Q05A e Q04E-Q05E .............................................................166

4.2.10. Análise dos pares de questões “O que é aprender"-“O que é aprender física?" (Q01A-Q16A) e

"O que é ensinar?"-"O que é ensinar física?" (Q01E-Q16E).........................................................................173

4.2.11. Análise das freqüências observadas das categorizações das respostas na dimensão a

Concepções de Educação .........................................................................................................................................177 


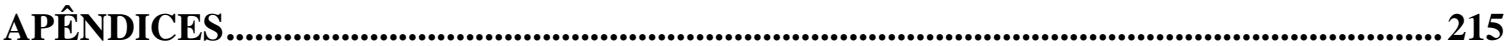

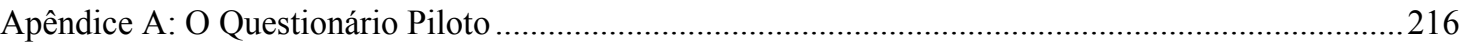

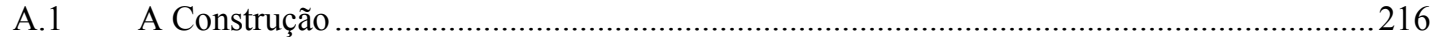

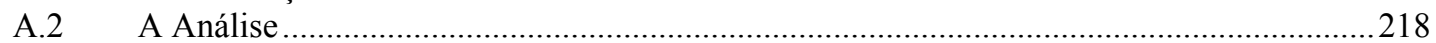

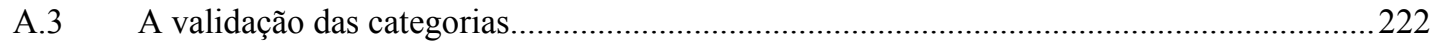

A.3.1. Dimensão Concepções de Educação ………………………………………………....222

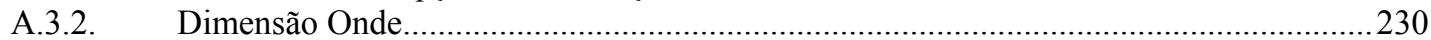

Apêndice B: Ementa da disciplina Elementos e Estratégias para o Ensino de Física...............................23

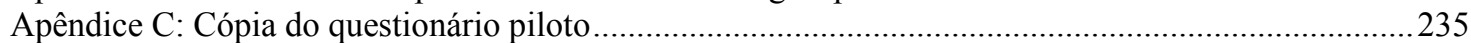

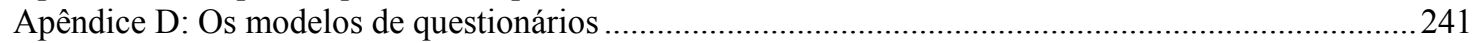

\section{ÍNDICE DE FIGURAS}

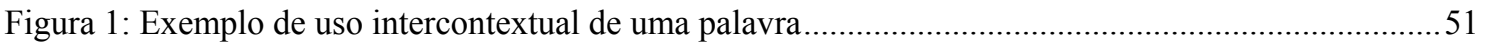

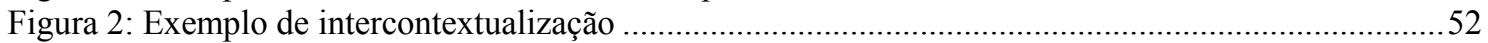

Figura 3: Esquema com as categorias utilizadas para construção das questões do questionário....................116

Figura 4: Distribuição das questões nos questionários. Na coluna "Aprender" estão as questões sobre aprender e na coluna "Ensinar" as questões sobre ensinar. As cores representam as duas metades das questões relacionadas à aprender e à ensinar........................................................................ 121

Figura 5: Exemplo de bloco de questão do questionário piloto ...............................................................217

\section{ÍNDICE DE TABELAS}

Tabela 1: Métodos, amostras, conceitos e zonas do perfil conceitual em trabalhos baseados na modelo de

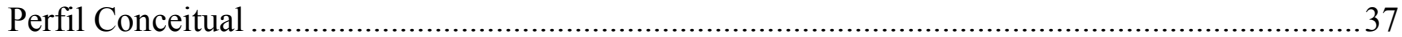

Tabela 2: Síntese das categorias de Concepções de Aprendizagem/Aprender e Ensino/Ensinar .............104

Tabela 3: Síntese da dimensão situação ........................................................................................ 113

Tabela 4: Questões e categorias do questionário ............................................................................ 124

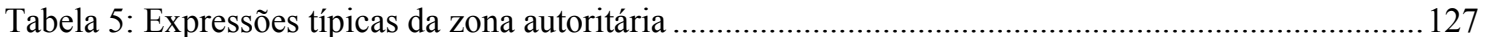

Tabela 6: Expressões típicas da categoria dialógica ......................................................................... 127

Tabela 7: Situação quanto ao ato de lecionar ou não dos estudantes - julho/2006 .............................. 131

Tabela 8: Onde lecionavam os estudantes - julho/2006 .................................................................... 131

Tabela 9: Há quanto tempo lecionavam os estudantes - julho/2006 .................................................. 132

Tabela 10: Onde lecionavam e carga horária semanal de prática docente dos estudantes - julho/2006 .. 132

Tabela 11: Turno que freqüentavam os estudantes - julho/2006 ...................................................... 133

Tabela 12: Outro curso superior que os estudantes freqüentavam(ram) - julho/2006......................... 133

Tabela 13: Forma pela qual os estudantes ingressaram na licenciatura................................................ 133

Tabela 14: Forma de ingresso, instituição e curso de origem dos estudantes....................................... 134

Tabela 15: Ano e forma de ingresso dos estudantes na Licenciatura ...................................................... 135

Tabela 16: Semestre que cursam e número de créditos dos estudantes - julho/2006 ........................... 135

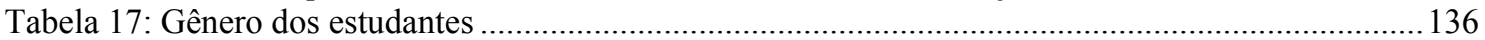

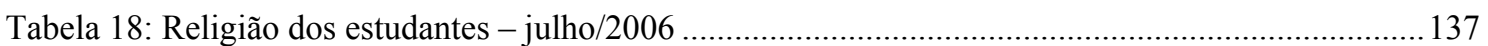

Tabela 19: Exemplo de tabela de dupla entrada: Relação entre cabelo e gênero (amostra fictícia) ..........139

Tabela 20: Correlação entre as categorizações das respostas coincidentes nos questionários na Dimensão

Concepções de Educação

Tabela 21: Correlação entre as categorizações das respostas coincidentes nos questionários na Dimensão Onde......

Tabela 22: Questões com nível descritivo do teste qui-quadrado menor que 5\%................................146

Tabela 23: Contagem da categorização das respostas das perguntas Q01A e Q04A em Concepções de Educação.

Tabela 24: Seleção de respostas e categorização em Concepções de Educação de Q01A e Q04A.......... 147 
Tabela 25: Contagem da categorização das respostas das perguntas Q04A e Q09A em Concepções de Educação.

Tabela 26: Seleção de respostas e categorização em Concepções de Educação de Q04A e Q09A..........153

Tabela 27: Contagem das respostas categorizadas às perguntas Q03A e Q11A em Concepções de Educação.

Tabela 28: Seleção de respostas e categorização em Concepções de Educação de Q03A e Q11A..........155

Tabela 29: Contagem da categorização das respostas das perguntas Q07A e Q11A em Concepções de Educação.

Tabela 30: Categorização das respostas de Q07A e Q11A quanto a Concepções de Educação do Questionário Final.

Tabela 31: Contagem da categorização das respostas das perguntas Q01A e Q19E em Concepções de Educação nas questões coincidentes

Tabela 32: Categorização das respostas de Q01A e Q19E quanto a Concepções de Educação ................ 162

Tabela 33: Contagem da categorização das respostas das perguntas Q04A e Q19E em Concepções de Educação.

Tabela 34: Categorização das respostas de Q04A e Q19E quanto a Concepções de Educação ................ 165

Tabela 35: Contagem da categorização das respostas das perguntas Q04A e Q05A em Concepções de Educação.

Tabela 36: Contagem da categorização das respostas das perguntas Q01A e Q19E em Concepções de Educação

Tabela 37: Exemplos de categorização dos pares de respostas Q04A e Q05A em Concepções de Educação.

Tabela 38: Exemplos de categorização dos pares de respostas Q04E e Q05E em Concepções de Educação.

Tabela 39: Contagem da categorização das respostas das perguntas “O que é aprender?" (Q01A) e "O que é aprender física?" (Q16A) em Concepções de Educação.

Tabela 40: Contagem da categorização das respostas das perguntas “O que é ensinar?" (Q01E) e "O que é ensinar física?" (Q16E) em Concepções de Educação.

Tabela 41: Exemplos de categorização dos pares de respostas Q01A e Q16A em Concepções de Educação.

Tabela 42: Exemplos de categorização dos pares de respostas Q01E e Q16E em Concepções de Educação.

Tabela 43: Categorias utilizadas para construção do questionário piloto.

Tabela 44: Expressões que geraram dúvida para a resposta dos estudantes, o sentido que se esperado e obtido e expressões ideais

Tabela 45: Expressões típicas utilizadas da categoria autoritária ......................................................224

Tabela 46: Seleção de respostas dadas a Q1 e Q2 no questionário piloto. .............................................224

Tabela 47: Seleção de respostas de estudantes na categoria duvidosa ...............................................225

Tabela 48: Respostas com dupla categorização..........................................................................227

Tabela 49: Relação entre a categorização das respostas em Q1 e Q2 .................................................228

Tabela 50: Seleção de respostas dadas às perguntas 11 e 40 categorizadas na categoria Onde?.............231 
INTRODUÇÃO 
Educar intencionalmente é uma atividade humana. O ser social constitui-se dialeticamente com a cultura. Esta por sua vez, é fruto do conhecimento histórico-cultural que foi construído pelos homens e selecionado pela cultura ao longo das sucessivas gerações (TOMASELLO, 2003). Isto é, o indivíduo (ou uma geração de indivíduos) é constituído a partir da cultura existente através do aprendizado. Após aprender, o indivíduo aperfeiçoa o conhecimento e o devolve através do ensino aos seus pares, que podem aceitar o conhecimento como ensinado, modificá-lo, ou simplesmente ignorá-lo. Tal conhecimento, caso tenha aceitação cultural dos pares, torna-se parte da cultura vigente e será ensinado às futuras gerações até que deixe de ser importante para seus pares, que eliminarão (ou esquecerão) tal conhecimento da "nova" cultura então vigente.

A cultura, portanto é o início, é o meio e é o fim de um processo dialético e cíclico ${ }^{1}$ de ensino/aprendizagem. Isto é, a "evolução" da cultura é proveniente dos desenvolvimentos individuais (ou de pequenos grupos) que têm sua origem no desenvolvimento cultural, o qual, por sua vez é fruto dos sucessivos desenvolvimentos individuais (LEONTIEV, 1978). Portanto, não é possível separar os indivíduos da cultura e a cultura dos indivíduos.

A Educação, da mesma forma que é indissociável do indivíduo, é indissociável dos conceitos ensinar ${ }^{2}$ e aprender. Não é possível se pensar o processo de (re)construção de conhecimento sem se pensar em ensino e em aprendizagem. Isso porque, o desenvolvimento da cultura e do indivíduo estão, necessariamente, atrelados à aprendizagem e ao ensino de práticas sociais.

\footnotetext{
${ }^{1}$ Denominado "efeito catraca" segundo Tomasello (2003).

2 Utilizaremos itálico para destacar as categorias utilizadas neste trabalho, o negrito para destacar conceitos-chaves e o sublinhado para destacar algo importante.
} 
A pesquisa em Educação tem se dedicado ao estudo dos conceitos ensinar e aprender, sobretudo, no desenvolvimento de metodologias para ensinar e procedimentos para avaliar o aprender. Contudo, nos cursos de formação de professores de ciências, raramente ocorrem discussões explícitas sobre "O que é ensinar?" e "O que é aprender?". Talvez alguma discussão seja realizada nas disciplinas de psicologia da educação sobre o "Como se aprende?" e nas disciplinas de metodologia e prática de ensino, o "Como ensinar?". Mas dificilmente se realiza uma discussão sistemática simultânea sobre estes conceitos, suas relações e a visão de educação que está por trás das opções metodológicas de ensino-aprendizagem. Neste sentido, nos propomos neste trabalho investigar os conceitos ensinar e aprender. Para tanto, realizaremos no Capítulo 3 um levantamento sobre as visões de ensinar e de aprender discutidas na bibliografia específica.

Uma das questões que poderiam ser discutidas, e que provavelmente influenciam no planejamento e avaliação do processo didático, é que os termos ensino e aprendizagem ora são usados como processo, ora como fim ou produto. Isto é, há o processo ensino que objetiva se chegar ao produto ensino (ou ensinado) e o processo aprendizagem que tem como fim a aprendizagem (ou aprendizado). Exemplos:

"O ensino [processo] da termodinâmica ocorreu nos meses de maio e junho.”; "O curso de formação de professores proporcionou uma melhoria no ensino [produto] de física moderna.”; “A aprendizagem [processo] de conceitos científicos ocorre em fases de exploração, introdução e aplicação do conceito a ser aprendido [produto]." e "Os estudantes demonstraram a aprendizagem [produto] no teste realizado sexta-feira".

Outra questão por trás do ensino e da aprendizagem, é que por vezes, espera-se que o processo de ensino seja integrado ao processo de aprendizagem 
(PASSMORE, 1980). Portanto, se espera também que o produto ensino se reflita no produto aprendizagem. Entretanto, quem ensina pode auxiliar àquele que aprende, porém não pode fazer a aprendizagem por este. O que pode ocorrer e influenciar na aprendizagem, é o compartilhamento de significados entre quem ensina e quem aprende (aprendiz). Quando os indivíduos compartilham significados, compreendem ao menos parcialmente - o que o outro pretende comunicar, e podem se apropriar do conhecimento, aprendendo.

Entretanto, não podemos restringir a aprendizagem aos casos que possuem uma pessoa que ensina diretamente. É possível também aprender por meio dos diversos artefatos culturais - livros, televisão, música etc. - impregnados de valores culturais e muitas vezes, construídos com fim educativo. Ainda é possível aprender por meio da observação e interação com o objeto a ser aprendido. A interação com o objeto não é isenta de valores a priori, pois toda a observação do indivíduo está baseada na cultura na qual o sujeito é co-participante desde seu nascimento. Portanto, pode ocorrer aprendizagem intencional sem quem ensine explicitamente, mas não ocorre aprendizagem sem cultura.

Ainda refletindo sobre ensinar e aprender, propomos que seja possível utilizar um conceito complexo de ensinar-aprender que contenha os conceitos ensinar e aprender.

Outra questão que se relaciona com ensinar e aprender são as visões de educação que estão por trás do processo educativo. Podemos dizer que existem duas formas básicas de se conceber a educação na relação entre quem ensina e quem aprende: uma educação dialógica e uma autoritária. Na educação autoritária, quem aprende restringe-se a receber e acumular o conhecimento - da mesma forma que ocorre o acúmulo de capital em um banco - tendo o aprendiz papel passivo no processo 
de ensino-aprendizagem. Enquanto que na educação dialógica, os indivíduos que ensinam e aprendem mudam de papel constantemente, pois o aprendizado é bidirecional, é tecido junto e nenhum dos indivíduos tem papel privilegiado no processo educativo.

Retomando a questão da formação de professores e tendo em vista que o professor possui papel determinante nos processos de ensino-aprendizagem formais, é relevante desenvolver pesquisas que estejam voltadas a conhecer as concepções de ciência, de educação, de ensino e de aprendizagem de professores e de professores em formação. Destes últimos, esperamos que na formação inicial passem a saber quais visões possuem e como as utilizam.

Ao se falar em levantamento de concepções, somos levados a pensar no desenvolvimento do ensino de ciências ocorrido nas últimas décadas. Isto porque, significativa parcela dos pesquisadores desta área, durante as décadas de 1970 e 1980, ocupou-se em pesquisar as dificuldades de estudantes e professores em aprender e usar concepções científicas e cotidianas. Identificaram concepções que os sujeitos envolvidos no ensinar-aprender utilizavam e que não correspondiam às concepções científicas vigentes. Tais concepções foram chamadas de concepções alternativas.

As concepções alternativas são aprendidas ao longo do desenvolvimento socio-histórico-cultural dos indivíduos e são importantes para o aprendizado de novos conhecimentos, inclusive os científicos. Várias estratégias com o objetivo de substituir as concepções alternativas pelas científicas foram criadas, aplicadas e avaliadas. Essas estratégias ficaram conhecidas dentro do movimento chamado de mudança conceitual ${ }^{3}$. Tais estratégias, por fim, não conseguiam realizar a substituição das concepções alternativas pelas científicas por completo. Por isso, desde

\footnotetext{
${ }^{3} \mathrm{O}$ trabalho que provavelmente teve maior impacto foi o de Posner et al. (1982).
} 
o final da década de 1980, a mudança conceitual passou a contar com novas metodologias e deixou de ser vista como a pura substituição conceitual. Passou-se então a considerar-se que a mudança é lenta e gradual - exigindo um maior tempo para o aprendizado do que era costumeiramente utilizado - ou na direção de considerar-se que os indivíduos pudessem possuir múltiplas concepções simultaneamente.

A segunda consideração foi proposta por alguns pesquisadores que consideravam os sujeitos possuem várias representações de um mesmo conceito, e que estas são utilizadas de acordo com o contexto. É o caso da noção de perfil conceitual (MORTIMER, $1995^{4}$ e 2000), na qual se considera que cada uma das diferentes concepções estabelece uma zona de perfil conceitual. Cada uma das zonas de perfil conceitual é utilizada dependendo do contexto.

Ao se verificar a utilização das zonas em contextos é possível verificar se os estudantes, além da adquirir as novas zonas de perfil, são capazes de utilizar estas nos contextos adequados. Isto é, não basta ter adquirido uma zona de perfil, é necessário que o ensino formal balize os estudantes a utilizarem as diversas zonas de perfil nos contextos adequados.

Apesar da relação entre perfil conceitual e contextos, verifica-se que a maior parte dos trabalhos em que se propõe medir perfis conceituais, durante a elaboração de instrumentos de coleta de dados, desconsidera a questão da utilização das zonas de perfil conceitual em contexto. Além disso, ao se realizar a medição de perfis conceituais é importante se considerar, simultaneamente, as dimensões ontológicas e epistemológicas propostas por Mortimer (1995, 2000), uma vez que cada zona de perfil pode ser menos ou mais influenciada por cada uma das dimensões. Portanto, não se atinge completamente a potencialidade que a noção de perfil conceitual oferece ao

\footnotetext{
${ }^{4}$ Todos os textos em língua diferente da portuguesa foram traduzidos pelo autor dessa dissertação.
} 
ensino de ciências ao se desconsiderar os contextos de uso das zonas de perfil e/ou as dimensões do mesmo. Consideramos ainda ser importante a inclusão de uma nova dimensão de cunho axiológico para se analisar perfis conceituais (VIGGIANO \& MATTOS, 2006a; 2006b, 2007; MATTOS \& RODRIGUES, 2006).

Tendo em vista a valoração que damos ao contexto, julgamos necessário que o mesmo seja devidamente estudado sob um ponto de vista teórico, e não como tem sido realizado na Educação em Ciências, na qual se utiliza o termo sem uma explicitação do que se concebe como contexto. Neste sentido, procuramos investigar de que forma os contextos são regidos por regras e princípios comunicativos que implicam atribuição de um ou outro significado.

Ao se assumir uma relação mais forte entre perfil conceitual e contexto, torna-se necessário que o instrumento de medida de perfis conceituais leve em conta o estabelecimento destes contextos, de forma a identificar o uso das zonas de perfil conceitual nestes. Assumimos também que é necessário fazer uma reflexão sobre o que é um conceito a partir de uma teoria psicológica e discutir a construção e a utilização das zonas de perfil conceitual em contextos.

No cenário em que se elegem conhecimentos e representações importantes para a prática pedagógica e a importância da formação de professores, nos propusemos a realizar o levantamento dos perfis conceituais de ensinar e de aprender de professores em formação inicial. ${ }^{5}$ Para tanto, optamos por construir um questionário com a finalidade de relacionar o uso das zonas de perfil conceitual em contextos

Ao se realizar o levantamento de perfis conceituais de ensinar e aprender - considerando os contextos de uso das zonas - esperamos contribuir para a

\footnotetext{
5 Estudantes da disciplina "Elementos e Estratégias para o Ensino de Física" oferecida pelo Instituto de Física da USP. A disciplina pertence ao terceiro ano da grade curricular da licenciatura em física.
} 
elaboração de recortes explícitos de conhecimento, de metodologias e enfoques que balizem discussões sobre cursos de formação de professores. Ao se considerar a importância dos contextos, percebe-se não somente a aquisição de novas zonas de perfil conceitual, mas também, como e quando são utilizadas as zonas de perfil.

Devido às relações existentes entre os processos e os produtos de ensinar e aprender, cremos que seja possível inferir sobre a existência de um perfil conceitual de ensinar-aprender. Isto porque, se existe uma relação sócio-cultural entre os conceitos ensinar e aprender provavelmente existe uma relação entre os respectivos perfis conceituais. Portanto, é relevante verificar se há uma relação entre o uso das zonas destes conceitos em contextos similares.

Antes de entrarmos na apresentação da seqüência do trabalho e na discussão teórica, é importante destacar que concebemos diversas formas de aprender e ensinar. Mas seria ingênuo dizer que não temos uma visão preferencial ou que somos neutros acerca do ensinar-aprender. Nos identificamos, principalmente, com a teoria sócio-histórico-cultural da psicologia do desenvolvimento e da aprendizagem, sobretudo aquela com base nos trabalhos de Vygotsky, Luria, Leontiev e Bakhtin.

Para atingir os nossos objetivos - levantar os perfis conceituais de ensinar e aprender, bem como a relação entre estes perfis e alguns contextos de uso das zonas - apresentaremos no Capítulo 1 o "Referencial Teórico". Nesse capítulo, realizamos uma breve discussão sobre concepções alternativas e mudança conceitual, chegando à noção de perfil conceitual proposta por Mortimer e aos trabalhos que a utilizam. Em seguida, para balizar as a relação entre uso de zonas e contextos, discutiremos o que é um conceito segundo a psicologia e a relação entre significados e contextos segundo a noção de contexto de Bernstein (1996). Encerramos o capítulo com a síntese do que assumiremos como perfil conceitual complexo. 
No Capítulo 2, discutiremos o "Problema de Pesquisa", apresentando as perguntas e hipóteses de trabalho, metodologias relativas à construção de questionários e à tabulação de dados e o que esperamos de um instrumento para elaboração de perfis conceituais.

Em complemento ao referencial teórico, apresentamos no Capítulo 3, entitulado "Ensinar e Aprender", um levantamento de categorias relacionadas a ensinar e aprender para identificar aquelas utilizadas para a identificação das zonas de perfil, bem como aquelas relacionadas com o estabelecimento de contextos de ensinar e aprender.

Consolidado o referencial teórico, o problema de pesquisa e as categorias, discutiremos no Capítulo 3, a construção, aplicação e análise do "Questionário", bem como alguns dos métodos de pesquisa utilizados. Em complemento a esse capítulo apresentamos no Apêndice A a elaboração e análise do "Questionário Piloto" que contribuiu para o desenvolvimento do questionário final.

No Capítulo 4, caracterizamos a amostra da pesquisa e analisamos os dados do questionário que teve como fim delimitar contextos que evocassem a utilização das zonas dos perfis conceituais de ensinar e de aprender.

No Capítulo 5, sintetizamos a análise, apresentamos os "Resultados" obtidos. E, por fim, apresentamos no Capítulo 6 as "Considerações Finais" do trabalho, devendo ser entendidas como reflexões finais e não como conclusões. 


\section{CAPÍTULO 1:}

\section{REFERENCIAL TEÓRICO}


Utilizamos como base o referencial teórico os trabalhos de Mortimer (1995, 1996 e 2000) e ressaltamos a noção de perfil conceitual como conceito central desta pesquisa. Apesar disso, retomamos aspectos dessa noção - as dimensões do perfil e os contextos de uso das zonas do perfil. Esta última, mesmo tendo sido proposta originalmente, não vem sendo considerada na maior parte dos trabalhos relativos à medida de perfil conceitual.

O principal aspecto que queremos ressaltar é a relação entre zonas dos perfis conceituais e sua utilização em determinados contextos. Além disso, propomos uma ampliação na noção de perfil conceitual, considerando-o como um objeto complexo, i.e., um perfil conceitual pode ter vários níveis hierárquicos em retroalimentação representando perfis conceituais de perfis conceituais (MATTOS \& VIGGIANO, 2007).

Para contextualizar a estas contribuições, apresentamos neste capítulo, um breve levantamento da pesquisa em Ensino de Ciências sobre o modelo de mudança conceitual (POSNER, STRIKE, HEWSON \& GERTZOG, 1982), a noção de perfil conceitual originalmente proposta por Mortimer $(1995,1996,2000)$ e a forma como essa noção vem sendo assumida por outros autores.

\subsection{Concepções alternativas e mudança conceitual}

Vários trabalhados desenvolvidos na área de pesquisa em Ensino de Ciências referem-se aos problemas ligados às dificuldades de ensinar e aprender conceitos científicos. Desde o final da década de 1970, um bem sucedido ramo de pesquisa nessa área tem se dedicado ao estudo das chamadas concepções alternativas. Tais concepções alternativas são utilizadas pelos estudantes (e mesmo por professores) 
em situações em que, usualmente, esperava-se o uso de uma concepção científica apropriada (DREYFUS et al., 1990, PACCA, 1983; PEDUZZI et al., 1992; PERRENOUD, 2000; DUIT \& TREAGUST, 2003b).

Nesta direção, o aprendizado de novos conceitos é influenciado pelo conhecimento prévio (ZYLBERSTAJN, 1983, DUIT, 1999; CHINN \& BREWER, 2003). As concepções alternativas podem ser consideradas conhecimento prévio uma vez que as mesmas fazem parte do arcabouço conceitual dos indivíduos antes do ensino formal $^{6}$ de um determinado conceito. Portanto, o Ensino de Ciências, que geralmente foca-se no ensino de conceitos, é diretamente influenciado pelas concepções alternativas, portanto sendo estas importantes para a educação científica (DRIVER \& EASLEY, 1978; GILBERT et al., 1982; POSNER et al., 1982; MORTIMER, 2000, DUIT \& TREAGUST, 2003a e 2003b).

Na literatura há uma longa discussão sobre os termos mais adequados acerca das idéias não científicas, como por exemplo: concepções alternativas, concepções prévias, conceitos prévios, idéias infantis, conceitos intuitivos, misconceptions, misunderstandings, modelos intuitivos etc. Neste trabalho, assumimos como concepções alternativas todas aquelas que não refletem diretamente às explicações científicas vigentes ou cujo uso fosse esperado em um contexto escolar.

Em alguns trabalhos desenvolvidos nas últimas décadas (e.g. VIENNOT, 1979), considerou-se que as concepções alternativas são exclusivamente provenientes do senso comum, num aprendizado informal. Porém, algumas destas podem ser provenientes do ensino formal, inclusive porque, alguns dos assuntos escolares não são amplamente discutidos no cotidiano não-formal dos estudantes.

\footnotetext{
${ }^{6}$ Assumimos como formal tudo aquilo que ocorre em instituições de ensino e não-formal o que ocorre fora de tais instituições.
} 
Citamos dois exemplos de aprendizagem formal das concepções alternativas: O primeiro se refere à explicação dada para a causa das estações do ano terrestre. Langhi (2004) constatou que para vários estudantes as estações do ano seriam causadas pela mudança da distância entre a Terra e o Sol, em função da excentricidade da trajetória elíptica de translação da Terra. Os termos "excentricidade" e "elíptica" não parecem ser do vocabulário cotidiano não-formal dos estudantes, portanto devem ser provenientes de um artefato formal de aprendizagem, seja livro didático, contato com professor, etc. O segundo caso se refere ao conceito de impenetrabilidade, presente em vários livros didáticos e que é assumido por vários professores como verdade científica, porém sua origem é filosófica (GASPAR \& MATTOS, 2002).

Em prosseguimento às pesquisas sobre concepções alternativas, desenvolveu-se um ramo de pesquisa que se dedicou aos problemas de aprendizado de conhecimentos científicos. Este ramo tinha como ponto de partida a substituição das concepções alternativas pelas científicas, e foi chamado de movimento de mudança conceitual. Os trabalhos mais significativos integrantes deste movimento surgiram no início da década de 1980 (HEWSON, 1981; POSNER et al., 1982; STRIKE \& POSNER, 1985) e propunham metodologias para se concretizar a substituição das idéias alternativas pelas científicas. O movimento de mudança conceitual tem este nome, pois o processo de substituição conceitual foi chamado de mudança conceitual. $\mathrm{O}$ termo mudança possibilita se pensar o processo de outras formas que não a substituição conceitual. Este poderia, por exemplo, considerar uma alteração em como o indivíduo trabalha com o conceito sem ter substituído a idéia prévia pela científica, passando a utilizar cada idéia de forma diferente (MORTIMER, 2000).

As idéias sobre a mudança conceitual adquiriram grande importância a ponto de alguns pesquisadores envolvidos na Educação em Ciências passarem a 
considerar o aprendizado de ciências como sendo a própria substituição conceitual (DUIT, 1999; MORTIMER, 2000; DUIT e TREAGUST, 2003b).

Várias metodologias para substituir as concepções alternativas pelas científicas foram propostas e aplicadas. Essas metodologias baseavam principalmente nas noções piagetianas de assimilação e acomodação (cf. VOSNIADOU, 1999; DUIT \& TREAGUST, 2003a) e na revolução científica proposta por Kuhn (1970). Abordaremos rapidamente as principais metodologias para proporcionar uma visão mais geral da mudança conceitual.

A primeira metodologia de mudança conceitual, e a que talvez tenha ganhado mais destaque, consistia na criação do conflito cognitivo. A maior parte dos trabalhos que se basearam nesta estratégia consistia basicamente na explicitação do equívoco das concepções alternativas dos estudantes através de uma contradição da concepção destes com relação ao resultado de uma experiência (conflito cognitivo). Portanto, ocorreria a apresentação do conceito científico como sendo mais abrangente e adequado que as concepções alternativas para explicar o fenômeno em questão. Dessa forma, com o "choque" do erro, os estudantes substituiriam as concepções alternativas pelas científicas.

Outra metodologia proposta para a mudança conceitual é o uso de analogias e metáforas. Esse uso, ao contrário do conflito cognitivo, não se foca na explicitação das concepções alternativas e parte do conhecimento prévio correto do estudante (MORTIMER, 2000, p.55). A generalização das analogias e metáforas refere-se ao conceito que se deseja ensinar. Esta metodologia minimiza o problema de perda de autoconfiança pelo estudante, pois não tem suas idéias conflitadas com as científicas, logo não insiste em usar as concepções alternativas (MORTIMER, 2000, 
p.54). Portanto, o processo se dá mais suavemente e com menos conflitos para o estudante.

Constatou-se que, nas duas metodologias apresentadas, a substituição conceitual é limitada, pois os estudantes continuam a possuir e utilizar as concepções alternativas (DUIT et al., 2003b). É possível que os estudantes tenham aprendido os conceitos e modelos científicos com as metodologias de mudança conceitual, mas não os utilizam nas situações cotidianas (DUIT, 1999).

Uma explicação possível para o fracasso das metodologias de mudança conceitual é que as concepções alternativas são complexas e capazes de explicar vários fenômenos cotidianos, mesmo que cientificamente a explicação não seja válida (GARCÍA, 1998). A complexidade de tais concepções deve-se ao fato destas serem aquisições sócio-histórico-culturais do indivíduo. Por esse motivo, as concepções alternativas são muito estáveis e as concepções científicas, apesar de mais bem definidas, dificilmente entram como ferramenta de resolução dos problemas cotidianos do estudante. Isto porque, quando um indivíduo é colocado a resolver um problema (mesmo que em um espaço formal de ensino) busca a forma que lhe é mais familiar para resolver o problema em questão e usa, em boa parte dos casos, a concepção alternativa.

Pelos resultados limitados obtidos com as metodologias apresentadas, alguns pesquisadores defendem outras formas de ver a mudança conceitual. Eles consideram que não ocorre uma troca rápida de concepções prévias por outras mais "potentes" ensinadas formalmente, mas ocorre um "enriquecimento conceitual" (DUIT, 1999; VOSNIADOU, 1999). Este processo de enriquecimento conceitual, diferentemente da visão clássica de mudança conceitual, considera que a mudança faz 
parte de um processo lento e gradual (VILLANI, 1992; VOSNIADOU, 1999, p.11; ENTWISTLE \& PETERSON, 2004).

Outra visão acerca da mudança conceitual, que também difere dos trabalhos da década de 1980, é conhecida como "teaching for conceptual change" (HEWSON et al. 2003, p. 200). Nessa visão, as metodologias devem explicitar os objetivos dos professores e concepções alternativas aos estudantes ao longo do processo educativo (HEWSON et al., 2003, p.203) para ajudá-los no processo de mudança conceitual. Outra alteração significativa nessa visão, é que, por meio dela, passa a conceber-se que além da aprendizagem por meio da mudança conceitual, seja possível que a aprendizagem ocorra de outras maneiras.

Ainda na linha de mudança conceitual, algumas propostas defendem que os indivíduos não substituem um conceito por outro, mas passam a lidar com cada um de forma diferente (DUIT, 1999). Logo, a mudança conceitual não ocorreria como uma revolução científica como é explorada por Posner et al. (1982), mas como a coexistência de múltiplas representações em um mesmo indivíduo (VOSNIADOU, 1999). Alguns autores (e.g. SPADA, 1994 apud VOSNIADOU, 1999; MORTIMER, 1995; DUIT, 1999; OLIVA MARTÍNEZ, 1999; MORTIMER, 2000; DUIT \& TREAGUST, 2003a; ENTWISTLE \& PETERSON, 2004) defendem que as múltiplas representações são utilizadas em contextos específicos. A coexistência e o uso contextual das idéias entram em choque com uma das idéias basilares da mudança conceitual fundada no conflito cognitivo e defendida por Hewson e Thorley (1989, p.543): "concepções conflitantes não podem ser simultaneamente plausíveis para uma pessoa".

Uma crítica que pode ser feita a boa parte das pesquisas desenvolvidas na linha das concepções alternativas e de mudança conceitual refere-se à 
indistinção entre concepções científicas e escolares. Vemos que esta indistinção leva a uma visão de escola com a função de ensinar o conhecimento científico vigente. No entanto, no desenvolvimento do trabalho científico, os cientistas utilizam modelos mais convenientes e não necessariamente os mais modernos para resolver cada um dos problemas pesquisados (BACHELARD, 1991). A escola ensina da mesma maneira, apresentando uma idéia escolar que pode diferir da idéia científica mais moderna. Portanto, grosso modo, podemos dizer que a escola não ensina o conhecimento científico mais moderno, mas uma aproximação deste. Podemos utilizar como exemplo a análise de livros didáticos para identificar a relação de escola e conhecimento científico na educação de Física no Ensino Médio. Da mesma forma, analisando os materiais direcionados aos professores, podemos identificar exemplos do uso de conceitos científicos que não são os mais modernos a serem adotados pelos professores. Um exemplo é o trecho transcrito abaixo do projeto de física GREF (1993):

Atualmente, a teoria aceita para descrever o comportamento de partículas elementares é o da Mecânica Quântica. Entretanto, nos restringiremos a outro modelo mais simples, baseado na Mecânica Clássica, elaborado pelo físico alemão Paul Drudde, em 1900, e desenvolvido pelo físico austríaco Anton Lorentz, em 1909 [...] (p.44)

\subsection{A Noção de Perfil Conceitual}

\subsubsection{A noção de perfil conceitual proposta por Mortimer}

Com o desenrolar do movimento de mudança conceitual, brevemente apresentado na seção anterior, começaram a aparecer sinais de sua limitação como modelo para se conceber o ensino-aprendizado de ciências. Em contrapondo, surgiu como alternativa substancial o modelo de perfil conceitual (MORTIMER, 1995). 
Assim, com base nas discussões que ocorreram na área de pesquisa em Ensino de Ciências nas últimas três décadas, elegemos neste trabalho a noção de perfil conceitual (MORTIMER, 1995), para fundamentar nossas discussões e propostas acerca da educação em ciências.

\section{A noção de perfil conceitual (MORTIMER, 1995 e 2000;} MORTIMER \& MACHADO, 1997) é baseada na noção bachelardiana de perfil epistemológico. Segundo Bachelard, os cientistas utilizam as visões epistemológicas ou zonas mais convenientes e não necessariamente as mais modernas para fazer Ciência. Cada uma destas visões é usada em diferentes freqüências e domínios. A diferença epistemológica define a hierarquia ${ }^{7}$ entre as zonas do perfil epistemológico, podendo variar para cada indivíduo. Isto é, quanto mais utilizada é a zona de perfil, maior é sua posição na hierarquia. Os domínios, por sua vez, se relacionam com o problema a ser resolvido. Bachelard (1991) acrescenta ainda que, nem todas as pessoas conhecem todas as visões filosóficas daquele conceito, portanto é possível que, ao se medir os perfis epistemológicos de indivíduos diferentes, não se identifique as mesmas zonas epistemológicas de um mesmo conceito.

Apropriando-se da noção de perfil epistemológico, Mortimer (1995, 1996 e 2000) propõe que cada indivíduo possui um perfil conceitual, o qual é composto por várias zonas de perfil conceitual que são várias representações de um mesmo conceito. A diferença mais significativa desta proposta teórica para a bachelardiana é a constituição das zonas de perfil conceitual não ser essencialmente epistemológica, mas também ontológica. Além disto, Mortimer (1995 e 2000) atribuiu uma dimensão didática e utiliza o termo contexto no lugar dos domínios de Bachelard.

\footnotetext{
${ }^{7}$ O termo "hierarquia" ora utilizado refere-se à freqüência de utilização das zonas. Nas demais utilizaçõs neste trabalho utilizamos este termo para nos referirmos à propriedade de sistemas complexos, que será posteriormente discutida.
} 
Além disso, há transferência da teoria filosófica Bachelardiana - que se refere à Ciência - para uma teoria Psicológica e Didática- referente à Educação em Ciências. Mortimer utiliza alguns elementos do interacionismo de Piaget e da psicologia sóciohistórica de Vigotski para justificar a utilização da teoria filosófica no campo psicológico.

Para Mortimer (1995 e 2000), a dinâmica considerada como mudança conceitual - antes entendida como substituição de uma concepção alternativa por uma científica (HEWSON, 1981; POSNER et al., 1982; HEWSON \& THORLEY, 1989; SCOTT, ASOKO \& DRIVER, 1991) - não ocorre essencialmente. O que ocorre é o processo de evolução do perfil conceitual, no qual o indivíduo, em um processo de ensino, aprende e passa a contar com novas zonas de perfil.

Mortimer (1996) argumenta que as experiências pessoais e sociais e a consciência sobre o próprio perfil conceitual influenciam na composição do mesmo. Logo, "ao tomar consciência de seu perfil, o estudante teria mais chances de privilegiar determinados mediadores e linguagens sociais, como aqueles mais adequados a determinados contextos" (MORTIMER, 1996, p.22). Pelo exposto, uma das formas de se contribuir para o aprendizado seria promover a conscientização dos estudantes sobre os seus próprios perfis conceituais (MORTIMER, 2000).

É nossa opinião que um dos pontos fundamentais da noção de perfil conceitual é a relevância da sua relação com os contextos os quais, de uma forma ou de outra, determinam como as zonas serão utilizadas pelo indivíduo.

\subsubsection{Trabalhos utilizando perfil conceitual}

As pesquisas que se propõem a realizar medidas de perfil conceitual utilizam-se, principalmente, três tipos de instrumentos de medida: 
i) Vídeo-gravações das atividades discursivas dos alunos durante o processo educativo (MORTIMER, 2000; AMARAL \& MORTIMER, 2004; KARAM et al., 2005);

ii) Entrevistas (COUTINHO et al., 2005) e

iii) Questionários (CUNHA, 2003; SANTOS \& CARBÓ, 2004; COUTINHO, 2005; KARAM et al., 2005; KARAM et al., 2006; RADÉ \& SANTOS, 2005; SILVA, 2006).

Em alguns casos, são utilizados, simultaneamente, os dois primeiros instrumentos de coleta de dados (e.g. MORTIMER, 2000 e 2003). As pesquisas que utilizam questionários (CUNHA, 2003; COUTINHO, 2005; SANTOS \& CARBÓ, 2004; KARAM et al., 2005; KARAM et al., 2006; RADÉ \& SANTOS, 2005; SILVA, 2006) atingem amostras maiores de estudantes que as demais metodologias.

Não ficam claras, no momento da elaboração das metodologias de $\underline{\text { levantamento de perfis conceituais, }}$ preocupações efetivas relacionadas às relações entre a utilização das zonas de perfil e contextos de uso. Além disso, não identificamos claramente em alguns trabalhos (e.g. CUNHA, 2003; AMARAL \& MORTIMER, 2004; SANTOS \& CARBÓ 2004) a consideração explícita e simultânea das duas dimensões de composição do perfil conceitual - ontológica e epistemológica - como propostas por Mortimer (1995).

Alguns trabalhos de levantamento de perfil conceitual foram realizados, como o de Mortimer (2000) e o de Santos e Carbó (2004), abordando o conceito de massa. Amaral e Mortimer (2004) utilizaram o tema entropia e privilegiaram, no levantamento dos respectivos perfis conceituais, a dimensão epistemológica. Já Coutinho (2005), realizou o levantamento do perfil conceitual de 
vida enfatizando a dimensão ontológica. O trabalho de Silva (2006), partindo do questionário de Coutinho (2005), delimita mais sistematicamente a diferença das dimensões ontológicas e epistemológicas. Karam et al., 2005 e 2006, apesar de destacarem que o conceito de tempo tem diferenças ontológicas e epistemológicas, não deixam claro quais as diferenças entre perfil conceitual e epistemológico e, apesar de utilizarem o termo perfil conceitual, não discorrem sobre a vantagem de se utilizar o perfil conceitual no trabalho.

Outra questão de ordem teórico-metodológica ligada à construção de instrumentos para o levantamento de perfil conceitual é ligada à hierarquia entre as zonas de perfil conceitual. Santos e Carbó (2004), por exemplo, procuram estabelecer uma hierarquia entre as zonas de perfil utilizando um questionário de 15 questões sobre massa. Porém, da forma como foi construído, este instrumento privilegiava algumas das zonas, pois continha um número maior de questões nas quais certas zonas eram mais apropriadas a serem utilizadas ${ }^{8}$. Isto é, por que um estudante utilizaria uma zona do perfil conceitual de massa segundo a visão quântica em um problema puramente clássico? É pertinente que um instrumento não possua o mesmo espaço para a manifestação das diversas zonas. Contudo, ao considerar a hierarquia entre as zonas, deve-se, necessariamente, construir um instrumento que propicie o estabelecimento de contextos em que seriam adequados os usos de uma e não de outras zonas de perfil conceitual.

Mortimer (2000) considera e discute brevemente a noção de contexto - em seu trabalho sobre atomismo - seu desenvolvimento parece ficar em segundo plano. Provavelmente, isso se deve ao enfoque adotado, que se volta para a análise da evolução dos perfis conceituais em sala de aula e para o aprofundamento teórico,

\footnotetext{
${ }^{8} \mathrm{O}$ autor não nomeia as zonas, apenas numera. Consideramos que o questionário privilegiava as zonas I, II e III.
} 
sobretudo ao que diz respeito à relação entre a noção de perfil conceitual e a psicologia da aprendizagem em espaços escolares. Verificamos que outros trabalhos (e.g. AMARAL \& MORTIMER, 2004; SANTOS \& CARBÓ, 2004 e COUTINHO, 2005;) que utilizam a noção de perfil conceitual, também não aprofundam a discussão sobre contextos.

Identificamos preocupações com a delimitação contextual nos trabalhos de Zaïne (2003) e Silva (2006). O primeiro trabalho refere-se ao conceito de energia em duas classes de níveis de ensino diferentes. Não fica explicito para nós, nestes trabalhos, qual é o marco teórico referente a contextos assumido. Os trabalhos parecem assumir que cada uma das turmas estabelece um contexto diferente.

Silva (2006) refere-se ao contexto na direção comunicativa, procurando analisar cada uma das perguntas, a partir do trabalho de Coutinho (2005), de forma a identificar quais contextos são "melhores" ou que privilegiam cada uma das zonas de perfil conceitual de vida. Apesar da amplitude do trabalho e da preocupação explícita do autor em conceitualizar contexto, sentimos dificuldades em identificar os critérios a priori delimitadores de contexto, isto é, não identificamos como a construção das questões foi focada na delimitação contextual. Fica claro no trabalho que alguns contextos são definidos e possibilitam relações entre as zonas de perfil e os contextos.

Tabela 1: Métodos, amostras, conceitos e zonas do perfil conceitual em trabalhos baseados na modelo de Perfil Conceitual

\begin{tabular}{lll}
\hline Trabalho & Métodos (amostra) & \multicolumn{1}{c}{ Conceitos / Zonas } \\
\hline Mortimer, 2000 & $\begin{array}{l}\text { Testes (24) } \\
\text { Video-gravações (5) }\end{array}$ & $\begin{array}{l}\text { Atomismo/estados físicos da } \\
\text { matéria: realista e sensorialista; } \\
\text { empírica; atomista clássica; }\end{array}$ \\
\hline $\begin{array}{l}\text { Amaral \& Mortimer, } \\
2004\end{array}$ & Video-gravações (?) & $\begin{array}{l}\text { Entropia e Espontaneidade: } \\
\text { perceptiva / intuitiva; empírica; } \\
\text { formalista; racionalista. }\end{array}$ \\
\hline
\end{tabular}




\begin{tabular}{|c|c|c|}
\hline Trabalho & Métodos (amostra) & Conceitos / Zonas \\
\hline $\begin{array}{l}\text { Santos \& Carbó, } \\
2004\end{array}$ & Questionários (28) & $\begin{array}{l}\text { Massa: sensorial; realista/empírica; } \\
\text { relacionada a peso; relativística; } \\
\text { relacionada à curvatura espaço- } \\
\text { tempo }\end{array}$ \\
\hline $\begin{array}{l}\text { Radé \& Santos, } \\
2005\end{array}$ & Questionários (?) & $\begin{array}{l}\text { Força: percepção a partir do esforço } \\
\text { físico; inerente à matéria ou } \\
\text { manifestação divina; atração dos } \\
\text { semelhantes; força imaterial; inércia; } \\
\text { quântica; relatividade restrita; } \\
\text { relatividade geral.9 }\end{array}$ \\
\hline Coutinho, 2005 & $\begin{array}{l}\text { Questionários (119) } \\
\text { Entrevistas (8) }\end{array}$ & $\begin{array}{l}\text { Vida: agente; artificialismo; } \\
\text { essencialismo macro; essencialismo } \\
\text { micro; finalismo; mecanismo; } \\
\text { relacional. }\end{array}$ \\
\hline $\begin{array}{l}\text { Karam et al., } 2005 \text { / } \\
2006\end{array}$ & $\begin{array}{l}\text { Questionários (21), } \\
\text { vídeo-gravações }\end{array}$ & $\begin{array}{l}\text { Tempo: psicológico; cronológico; } \\
\text { absoluto de Newton; Discreto; } \\
\text { Determinístico; Tempo e } \\
\text { Probabilidade; Tempo relativístico }\end{array}$ \\
\hline Cunha, 2003 & Testes $(47)^{10}$ & $\begin{array}{l}\text { Atomismo: As mesmas de Mortimer } \\
(2000)\end{array}$ \\
\hline Solsona et al., 2003 & Ensaios (51) & $\begin{array}{l}\text { Mudança química: interativo; } \\
\text { mecânico; da cozinha; incoerente. }\end{array}$ \\
\hline Silva, 2006 & Questionários (237) & As mesmas de Coutinho, 2005. \\
\hline Zaïne, 2003 & Questionários (40) & $\begin{array}{l}\text { Energia: familiar; energia clássica; } \\
\text { fotométrica; energia quântica. }\end{array}$ \\
\hline
\end{tabular}

\subsection{Um Perfil Conceitual Complexo}

Assumimos a noção de perfil conceitual proposta por Mortimer (1995, 1996 e 2000) com alguns destaques e modificações. Privilegiamos o perfil conceitual com base nas teorias sobre conceitos da psicologia cognitiva. Nessa direção, realizamos uma breve exposição sobre conceitos, elegendo a visão de rede e de perfil conceitual como norteadora desta pesquisa.

Por outro lado, a noção de contexto que assumimos se apóia nas idéias de Bernstein (1996). Propomos a analogia entre atribuição de significados em virtude do contexto - discutido por Bernstein (1996) - e o uso das zonas de perfil em

\footnotetext{
${ }^{9}$ As zonas de perfil definidas pelos autores é bastante confusa e questionável devido à mistura entre aspectos ontológicos e epistemológicos diferentes.

${ }^{10}$ Esta autora, como os anteriormente atribuídos como teste, denominam seu instrumento de teste. Para nós seria mais adequado utilizar a expressão questionário.
} 
contexto. Para realizar integração entre conceitos, perfil conceitual e contextos, realizamos algumas considerações com base na teoria sócio-histórico-cultural partindo do pressuposto que: a linguagem faz a mediação entre os sujeitos e o mundo (VIGOTSKI, 2001). Deste ponto de vista, ao identificarmos os significados atribuídos em um determinado contexto é possível inferir sobre a constituição e a dinâmica dos perfis conceituais dos indivíduos.

Mortimer (1995 e 2000) considera os contextos como sendo importantes para os perfis conceituais. Neste trabalho, acentuamos a função dos contextos, considerando que estes são essenciais para a utilização e para a evolução de novas zonas do perfil conceitual. Porém, diferimos ao propor que além dos elementos (ou dimensões) ontológicos e epistemológicos, existe uma dimensão axiológica na constituição das zonas de perfil conceitual. O pressuposto de que partimos é de que o conhecimento humano também tem essas três dimensões (FIEDLER-FERRARA \& MATTOS, 2002). Assim, todos os contextos de vivência humana são constituídos com essas mesmas dimensões. Portanto, consideramos que o uso das zonas de perfil conceitual ocorre a partir da composição de cada uma dessas no contexto, privilegiando uma ou outra zona do perfil conceitual (VIGGIANO \& MATTOS, 2006c).

Outra diferença que assumimos se refere à noção de evolução do perfil conceitual - a aprendizagem -, que passa a ser entendida tanto como a inclusão de novas zonas do perfil conceitual - como proposto por Mortimer (1995, 2000) como também a modificação das zonas prévias do perfil (VIGGIANO \& MATTOS, 2006b, 2006c; RODRIGUES \& MATTOS, 2007). A qualidade se relaciona com as diferentes intensidades das dimensões do perfil conceitual. Quando uma dimensão tem maior valor ou prioridade sobre as outras consideramos que essa prevalece, e seus 
aspectos serão os predominantes e responsáveis pela eleição das zonas de perfil conceitual a serem utilizadas naquele contexto.

Sabendo-se que os contextos têm papéis importantes na aprendizagem (PURDIE \& HATTIE, 2002), assumimos também que a evolução do perfil conceitual, como a inclusão de novas zonas, pode também ser entendida - devido à importância dada aos contextos na noção de perfil conceitual ora assumida - como a modificação temporal do uso das zonas em contextos semelhantes ${ }^{11}$ (VIGGIANO \& MATTOS, 2006c). Assim para fundamentarmos a discussão passamos, na próxima seção, a discutir o "conceito de conceito".

\subsubsection{Conceitos}

Até o momento utilizamos os termos concepções, visões, idéias e conceitos praticamente no mesmo sentido. Faremos uma distinção mais clara entre o último termo e os demais, a princípio, os primeiros termos são mais amplos e abertos, enquanto os conceitos são uma representação mais sistematizada.

Os conceitos são amplamente discutidos, constituindo-se objeto de diversas áreas de pesquisa ${ }^{12}$. Apresentamos brevemente parte da discussão realizada nas últimas décadas sobre conceitos. Apesar de nosso interesse acerca deste ramo de pesquisa da psicologia, faremos apenas uma explicitação dos pontos mais relevantes, deixando para trabalhos futuros o aprofundamento no tema.

\footnotetext{
${ }^{11}$ Viggiano e Mattos (2006c) apresentam indicativos da ocorrência de modificação do uso de zonas em contextos semelhantes.

${ }^{12}$ Ver o volume da revista Mind \& Language 19(1), pp. 1-112 de fev. de 2004,
} 
$\mathrm{Na}$ psicologia há basicamente quatro visões ${ }^{13}$ sobre conceitos: a clássica, a prototípica, a dos exemplares e a de rede (HEIT, 1997; LOMÔNACO et al., 2004).

A visão clássica (SMITH \& MEDIN, 1981) procura definir um conceito a partir das similaridades de atributos dos elementos, sendo desconsiderados os atributos diferentes. Esta definição é limitada, sobretudo, porque modificar os atributos de um elemento sem descaracterizá-lo completamente, implica uma dificuldade de identificação e classificação de um exemplar naquele mesmo conceito, como pode ser verificado no exemplo a seguir:

“[...] Quais são os atributos definidores de cão? Ser um animal doméstico de quatro patas, que late e tem pêlos? Suponhamos, então, que nosso hipotético cão perca uma pata em acidente e/ou seus pêlos em virtude de alguma doença de pele. Ou que em função de alguma doença na garganta, perca a capacidade de latir." (LOMỔNACO et al., 2004, pp.24-25)

Por outro lado, na visão prototípica, os conceitos são considerados os atributos mais comuns de um exemplar, o qual, mesmo com um ou outro atributo modificado, não deixa de ser categorizado no conceito original. Dessa forma, elegemse alguns - os mais importantes e não necessariamente todos - atributos que sejam, em sua maioria, comuns para se caracterizar determinado conceito. A partir desta seleção, define-se um protótipo ou alguns protótipos que serão utilizados como base para identificar - a partir da similaridade - quais elementos fazem ou não parte daquele conceito (HAHN \& CHATER, 1997). Desta forma, ao modificar-se uma característica do objeto - mesmo que uma principal -, não há problemas mais sérios - como na visão clássica - para se realizar a categorização em determinado conceito, pois a maioria dos

\footnotetext{
${ }^{13}$ Identificamos que alguns autores (HAHN \& CARTER, 1997; LOMONACO et al., 2004 etc.) utilizam os termos teoria, visões ou concepções para falar das diferentes perspectivas teóricas acerca de conceito.
} 
atributos se preserva, sendo categorizado no mesmo conceito. Nesta visão, os protótipos são suficientes no ato da comparação.

O principal problema ou limitação da visão prototípica é que, como não há um critério delimitador objetivo para a escolha dos atributos, o limite dos conceitos torna-se muito amplo, estendendo o conceito de tal forma, que este passa a representar algo pouco significativo (LOMÔNACO et al., 2004). Ou seja, como há liberdade acentuada na escolha dos atributos que caracterizam um conceito, é possível identificar características semelhantes entre uma casa e um carro convencional, como por exemplo: os dois comportam pessoas em seu interior, têm um revestimento que abriga da chuva, têm portas, vidros, etc. Com isso se criaria um conceito que não teria muito sentido no cotidiano, desconsiderando o que de melhor representaria o carro (ser um meio de transporte) e a casa (lugar para habitar). É possível que alguém more em um carro, mas dificilmente alguém utilizaria uma casa convencional como meio de transporte.

Há ainda críticas à visão prototípica relacionadas à construção de conceitos compostos, como por exemplo, "mulher branca, obesa, pobre e feliz", pois a cada característica incluída no conceito se criaria outro conceito, levando à proliferação exagerada destes. Além disso, quando há conceitos que estão na limitação entre dois outros ocorrem dificuldades de categorização, por exemplo, trailers e casas-barco, seria necessária a criação de dois novos conceitos expressos por exemplares, levando a um significativo aumento do número de protótipos.

A terceira visão referente a conceitos é chamada de visão dos exemplares. Pressupõe-se que ao longo do tempo, o indivíduo constrói um conjunto de exemplares, os quais são tratados como sendo o próprio exemplo do conceito. Esta visão se baseia na idéia de coesão conceitual, que se refere a quais características 
podem ou não ser utilizadas para agrupar e relacionar os exemplares (LOMÔNACO et al., 2001). Portanto, por similaridade com os exemplares de conceito, um elemento é classificado ou não em um conceito. Como na visão prototípica, a proliferação desnecessária de conceitos e protótipos, ocorre o aumento expressivo dos exemplos para exprimir os conceitos compostos. Este aumento é ainda mais grave que no caso anterior, pois mesmo um conceito compostos poderia ser aproximado aos protótipos de conceitos mais simples, enquanto que os exemplos são identificados teriam que ter todas as características, tendo necessariamente que se identificar outro exemplar. Além disso, um conceito pode possuir vários exemplares. Outra questão que fica em aberto é sobre os conceitos abstratos, que dificilmente terão um exemplar simples de se caracterizar e identificar.

As três visões sobre conceitos apresentadas até o momento baseiamse na noção de similaridade (HAHN \& CHATER, 1997). A similaridade ocorre quando é possível agrupar objetos (ou entidades ou elementos) de acordo com suas características similares. Ao relacionar similaridade e conceitos, há duas alternativas possíveis:

a) Os conceitos podem ser utilizados para explicar as similaridades.

b) As similaridades podem ser utilizadas para explicar os conceitos.

Ao se apoiar na similaridade, essas visões ficam fragilizadas, uma vez que a mesma torna a caracterização do conceito muito flexível. Isto porque a caracterização é afetada pela escolha dos atributos similares, i.e., definir conceitos a partir do que é similar faz com que a mudança dos atributos eleitos (ou a perda de um dos atributos) descaracterize o conceito, causando dificuldades na categorização de um elemento em determinado conceito (LOMÔNACO et al., 2004). Além disso, a 
similaridade esbarra na subjetividade do que é similar ou não. Portanto, esta não se mostra plenamente adequada para caracterização dos conceitos.

Como alternativa às visões cujo pressuposto é a similaridade, surgiu a visão de rede ${ }^{14}$. Nesta se assume que o conceito não é um elemento isolado, mas parte de uma rede de conceitos interligados. A rede de conceitos constitui uma teoria ${ }^{15}$. Portanto, segundo a noção de rede os

"conceitos são construídos como tipos de coisas intrinsecamente relacionais. Eles não são entidades isoladas, conectadas apenas a serviço de proposições. Nenhum conceito individual pode ser compreendido sem algum entendimento de como ele se relaciona com os outros conceitos" (KEIL, 1989, apud LOMÔNACO et al., 2004, p.28),

além disso

"os conceitos constituem um determinado tipo de agrupamento cognitivo - uma representação mental - que possibilita ao organismo reduzir drasticamente a complexidade do ambiente" (LOMÔNACO et al., 2001, p.161).

Neste trabalho entendemos que um dos aspectos fundamentais que deve ser incluído no modelo de perfil conceitual é a noção de rede.

\subsubsection{Perfil Conceitual Complexo}

Neste sentido, partimos do pressuposto teórico de que o perfil conceitual é um objeto complexo que pertence a uma rede de perfis conceituais de perfis conceituais, composta por diversos níveis hierárquicos ${ }^{16}$ que se retrointeragem.

\footnotetext{
${ }^{14}$ Há autores (e.g. LOMÔNACO et al., 2004) que utilizam a expressão visão teórica, porém, achamos mais conveniente utilizar visão de rede por ser mais próxima da representação que assumimos e por ser mais simples o entendimento do que é uma rede que uma teoria.

${ }^{15}$ Teoria neste sentido não se restringe à teoria científica, mas a um conjunto de objetos e argumentações interligadas para explicar algo.

${ }^{16} \mathrm{O}$ termo "hierarquia" e correlatos, a partir deste ponto, diferem do conceito de hierarquia de zonas de
} 
Em particular, propomos que os conceitos ensinar e aprender podem ser entendidos como perfis conceituais individuais e, ao mesmo tempo, pertencentes a um perfil conceitual hierarquicamente superior que englobaria esses dois perfis conceituais. Nessa perspectiva, podemos conceber um perfil conceitual complexo, que corresponde ao perfil conceitual de ensinar-aprender.

Nesta representação geométrica, podemos definir um espaço conceitual, no qual os conceitos são representados como os nós da rede, cujas interações podem ser modeladas de diversas formas. Por exemplo, podem ser modeladas usando-se o critério da similaridade, o que definiria grupos de proximidade entre os nós.

Partindo do modelo de rede destacamos a a arquitetura de rede, assumindo que ao invés de pontos, os nós da rede têm estrutura, e são os perfís conceituais compostos por suas zonas. Nessa representação, cada zona de um perfil conceitual pode estar ligada às diversas zonas de outros perfis conceituais. Isto significa um aumento de complexidade na representação do perfil conceitual. Os agrupamentos podem ser representados, nesse espaço mais complexo, como um perfil conceitual composto de perfis conceituais.

A representação do uso de certos subgrupos dessa rede complexa pode ser descrita pela hipótese da ressonância (MATTOS \& RODRIGUES, 2007, MATTOS et al., 2008), na qual certas interações entre zonas de perfil conceitual são privilegiadas frente a contextos específicos de uso. Aqui, não temos mais conceitos representados como nós, nem sua relação como fios, mas sim, perfis conceituais como 
volumes cujas partes (zonas) se relacionam com outros volumes (outros perfis conceituais).

Dada essa representação geométrica, precisamos agora dar corpo aos fundamentos do significado de contexto que pretendemos usar para dar conta desse modelo de perfil conceitual complexo, o que faremos na próxima seção.

\subsubsection{Significados, Contextos e Educação}

Ao privilegiar a função do contexto na utilização das zonas de perfil conceitual, torna-se importante definir contexto. Utilizamos algumas das idéias de Bernstein (1996) sobre contexto e significado que atrelam o estabelecimento de contextos à interação social e têm como idéias chaves: o princípio comunicativo interativo; o princípio comunicativo localizacional; regras de reconhecimento, regras de realização e regras de enquadramento.

O princípio comunicativo localizacional refere-se aos meios que permeiam a interação e ao local onde ocorre a interação, dando sentido espacial à interação. $\mathrm{O}$ princípio comunicativo interativo refere-se às vestimentas, à formalidade entre os interagentes e também atribui sentido temporal à interação, bem como se relaciona à posição dos indivíduos na interação (transmissor/receptor). Portanto, tal princípio regula o seqüenciamento e a seleção dos elementos comunicativos a serem utilizados na interação, sendo a característica dominante nos contextos uma vez que regula e inter-relaciona os dois princípios.

As regras de reconhecimento são responsáveis pela delimitação e identificação do contexto e são obtidas a partir de elementos externos a este. Elementos internos são aqueles que só fazem sentido naquele contexto, externos não se enquadram especificamente e não influenciam na interação imediatamente 
estabelecida $^{17}$. Neste sentido, existem múltiplos contextos, indo de contextos dos mais amplos e menos definidos (macro-contextos) aos mais específicos (micro-contextos) e estritamente relacionados com a dinâmica da interação que está ocorrendo.

Um exemplo para a pluralidade ${ }^{18}$ de contextos é que em uma escola há certo padrão de interação, normas, vestimentas adequadas e espaços onde podem ocorrer as interações, podendo ser definido como um macro-contexto. Uma sala de aula da mesma escola, apesar de possuir e de seguir mais ou menos as normas da escola, desenvolve regras um pouco diferenciadas e relacionadas pela atividade central da sala de aula, seja o ensino-aprendizagem de certo conceito, seja o desenvolvimento de uma atividade. Apesar de inserida em um macro-contexto, a sala de aula conta com suas próprias regras de reconhecimento que estabelecem seu micro-contexto.

Determinar se um contexto é um macro-contexto ou um microcontexto depende da referência escolhida na hierarquia de contextos. Por exemplo, a escola frente ao sistema educacional é micro-contexto, a sala de aula frente às interações dos pequenos grupos é macro-contexto.

As regras de reconhecimento referem-se às fronteiras do contexto, que são por sua vez demarcadas pelo entorno. Portanto, as regras de reconhecimento são delimitadas por fatores externos aos contextos. Isto é, um contexto está estabelecido até o momento que as características externas mudem e o modifiquem.

Além disso, as regras de reconhecimento são intimamente relacionadas aos vínculos existentes entre os princípios comunicativos. Segundo Bernstein (1996), as regras de reconhecimento relacionam significado com contexto,

\footnotetext{
${ }_{17}^{17}$ Salvo os casos de intercontextualidade, como será brevemente discutido.

${ }^{18}$ Também chamamos de hierarquização dos múltiplos contextos.
} 
As regras de reconhecimento regulam o que vai com o quê: que significados podem ser legitimamente reunidos, que relações referenciais são privilegiadas/privilegiantes. (p.50)

Já as regras de realização referem-se ao que ocorre no contexto, sendo constituídas a partir dos elementos internos e são definidas a partir das regras de enquadramento.

As regras de enquadramento relacionam-se ao modo como a comunicação ocorre entre transmissores e adquirentes ${ }^{19}$. Um enquadramento forte implica uma interação baseada em um transmissor mais ativo e um receptor mais passivo, enquanto que um enquadramento fraco implica uma relação onde os indivíduos mudam constantemente de posição, ora assumindo-se como transmissores e ora como receptores, indicando uma interação com elementos dialógicos mais presentes. Por este motivo, as regras de enquadramento influenciam diretamente o princípio comunicativo interativo, uma vez que regula os papéis dos indivíduos na interação. Um enquadramento forte valoriza a assimetria do conhecimento, supervaloriza o papel de um detentor do saber, por exemplo, o professor na sala de aula. Nesse caso, o professor assume a função de transmissor mais efetivo quando o enquadramento forte prevalece, enquanto que troca de conhecimentos é mais viável e presente nos contextos com enquadramento é fraco.

Sob o ponto de vista da teoria socio-histórica, Edwards e Mercer (1987) propõem características semelhantes aos princípios e regras propostas por Bernstein. De forma superficial, podemos relacionar o princípio comunicativo interativo ao contexto mental, o princípio comunicativo localizacional ao contexto físico. Contudo, optamos por utilizar as idéias de Bernstein, pois esse oferece subsídios

\footnotetext{
${ }^{19}$ Bernstein (1996) parece assumir a noção clássica de comunicação. Na perspectiva deste trabalho podemos pensar em "sujeitos que interagem". O transmissor pode ser entendido como "o principal responsável pelo ensino" e o adquirente como "aprendiz".
} 
para se pensar em múltipos contextos e hierarquia de contextos, o que permite realizar uma relação mais explícita com a noção de perfil conceitual complexo.

Para Bernstein, os significados assumem papel importante na comunicação e estes são atribuídos de acordo com o contexto. Eles são identificados ${ }^{20}$ por meio dos elementos discursivos, que refletem os princípios comunicativos, as regras de reconhecimento, de realização e de enquadramento do contexto estabelecido.

Apesar das idéias de Bernstein parecerem indicar um contexto estático, consideramos, neste trabalho, que o contexto tem uma dinâmica, que em alguns momentos não modifica tão rapidamente, isto é, tem certa linearidade e estabilidade, e em outros momentos, ocorrem modificações mais rápidas e turbulentas. Assim, com o desenrolar da interação, as regras de reconhecimento, enquadramento podem ser modificadas, levando à modificação do contexto. Portanto, o contexto é dinâmico e é modificado ao longo do processo interativo de acordo com o desenrolar das formas de comunicação.

A dinâmica do contexto relaciona-se diretamente com o enquadramento e este permite ou não a mudança. Isto é, um enquadramento muito forte restringe a evolução do contexto uma vez que um indivíduo é o principal responsável pelos elementos lingüísticos que permitem a identificação e definição do contexto. Em um contexto com enquadramento mais fraco, a ação mais ativa dos diversos interagentes permite que mais indivíduos gerenciem efetivamente as regras de reconhecimento, reconstruindo o contexto.

Um professor "autoritário", por exemplo, define quais significados deverão ser privilegiados para aquele contexto, sem levar em consideração a opinião

\footnotetext{
${ }^{20}$ Usamos os termos identificar, definir, estabelecer e fechar contextos no sentido de delimitação contextual, isto é, estabelecimento de regras que demarquem os contextos.
} 
dos alunos. Assim, delimita o contexto com base na realização de suas próprias regras de reconhecimento. Já em um enquadramento mais fraco, o professor permite que os estudantes introduzam, com perguntas e comentários, novos elementos marcadores de regras de reconhecimento. Na primeira situação, as frases ou exemplos escolhidos pelo professor provocam a dinâmica contextual, enquanto que na segunda situação os alunos podem propor elementos a serem incluídos na discussão levando à redefinição do contexto.

Como argumentamos anteriormente, para Vigotski (2001) a linguagem faz a mediação entre o sujeito e o mundo, definindo as formas de interação entre os sujeitos. Da mesma forma, para Bernstein (1996), os sentidos são atribuídos de acordo com o contexto, definindo a interação do sujeito com seu entorno.

Nesta direção, o sentido atribuído a uma situação assume papel fundamental para se entender a relação entre perfil conceitual e contexto, pois indica qual o recorte o sujeito faz na situação, o que define o contexto no qual se percebe inserido.

Quando há o compartilhamento de sentidos, surge o significado, se estabelece a intersubjetividade $^{21}$ (VILA, 1998), e o papel comunicativo (mediacional) da linguagem é cumprido. Quando os elementos textuais (dêixis) não são suficientes, pode ocorrer falta de compreensão e clareza dos enunciados, levando a uma comunicação limitada. Na comunicação os interagentes procuram fornecer elementos lingüísticos para estabelecer o contexto no qual possam estabelecer o melhor compartilhamento possível de significados.

\footnotetext{
${ }^{21}$ Entendida como "o conhecimento comum que dois interlocutores possuem em relação com o tema compartilhado" (VILA, 1998, p. 67, tradução livre)
} 
Ao longo da interação, os indivíduos evocam outros contextos, de forma a trazer novas perspectivas e facilitar a comunicação. Para tanto utilizam, por exemplo, analogias, metáforas ou ironias. O discurso, nesta situação, é constantemente permeado de elementos intercontextuais, como, por exemplo, as situações apresentadas na Figura 1 e na Figura 2

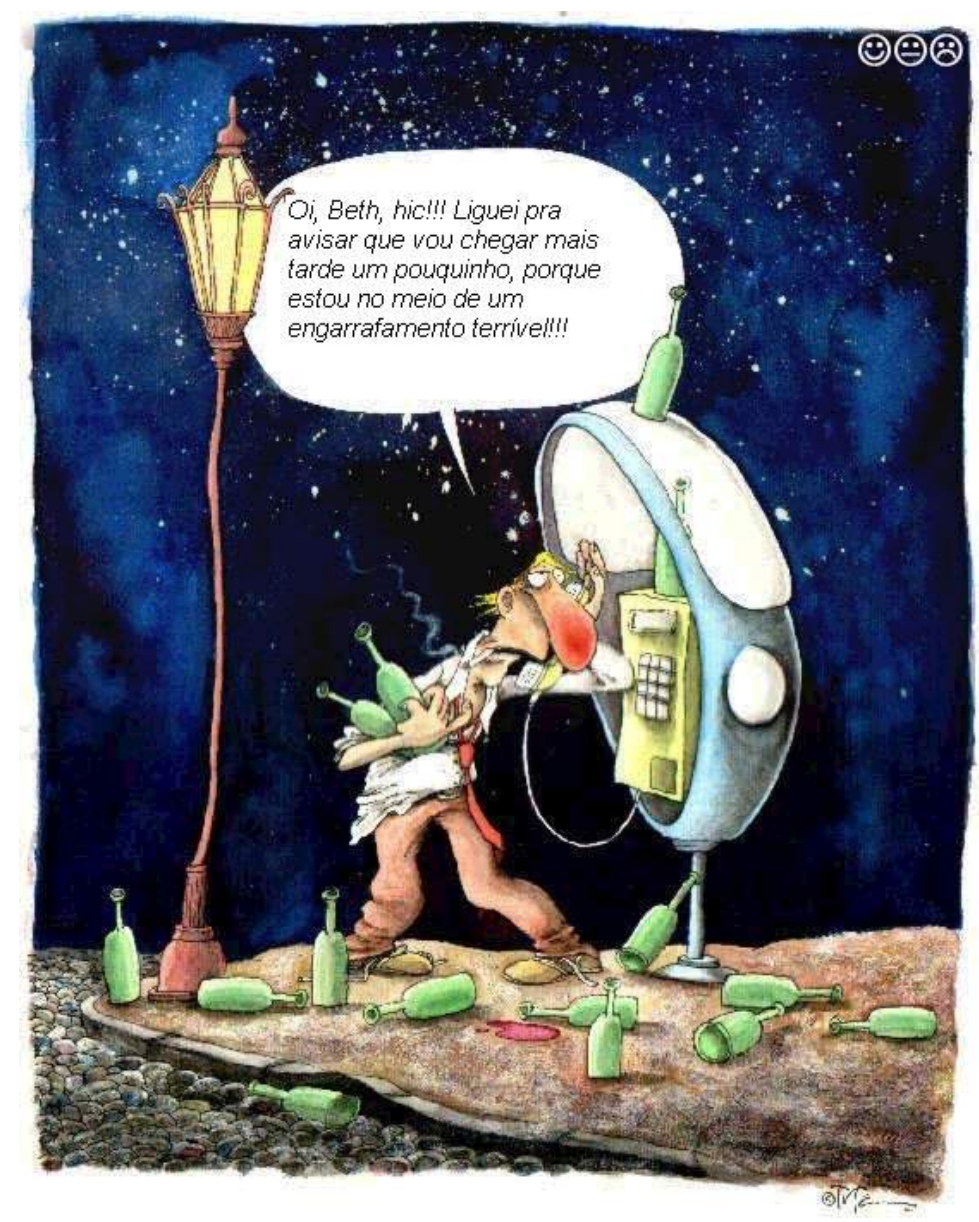

Referência: Autor não identificado

Figura 1: Exemplo de uso intercontextual de uma palavra 


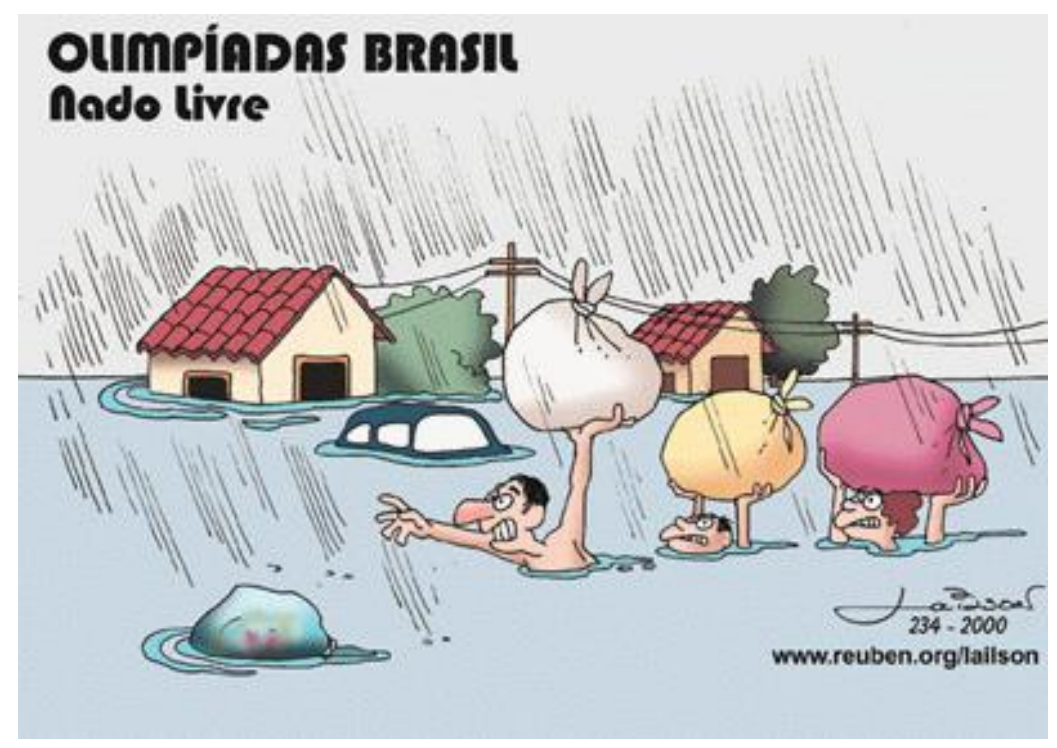

Referência: Copyright 1999-2004 - Lailson de Holanda Cavalcanti/LHC Associados

Figura 2: Exemplo de intercontextualização

Nestes exemplos, a ironia é utilizada para expressar algo que se queira fazer de forma não habitual, normalmente para ser trágico ou cômico. Para tanto o significado de uma palavra é evocado em outro contexto. A palavra “engarrafamento" tem dois significados mais comuns na língua portuguesa (HOUAISS, 2001): "colocação ou acondicionamento em garrafa" e "impossibilidade de circulação". No caso, o falante do exemplo (Figura 1) refere-se ao significado figurado (já que está "em meio a garrafas" e não "acondicionado em”) e adequado, contudo diferente do comumente atribuído em contextos relacionados a atrasos. A interlocutora "Beth" provavelmente entendeu engarrafamento como congestionamento, por ser o significado mais habitual quando se fala em dificuldade de deslocamento. Portanto, os interagentes encontram-se em contextos diferentes, e se referem a significados diferentes. Se a referência contextual exofórica foi usada propositalmente (ou não) para gerar comunicação, é uma questão para ser discutida levando-se em conta a inclusão da dimensão axiológica do perfil conceitual. 
No exemplo (Figura 2) é feita alusão à modalidade de natação "nado livre", que geralmente ocorre nas olimpíadas. $O$ autor explicita que faz intercontextualidade ao escrever "Olimpíadas no Brasil”. Naquele período aconteciam os jogos olímpicos de Sidney, o autor critica a preocupação excessiva que era dada ao evento e a conseqüente falta de atenção aos problemas sociais que ocorriam no mesmo período. Logo, há uma sobreposição de contextos, o primeiro é o estabelecido entre autor e leitor (macro-contexto), e os outros dois se referem à situação política e os jogos olímpicos (micro-contextos), que são trazidos para o macro-contexto autor-leitor.

Outro caso que caracteriza a superposição de contextos é a escola tradicional, espaço cultural que privilegia certos tipos de interação, sobretudo as relacionadas ao ensinar-aprender conhecimentos científicos e tecnológicos. A escola privilegia o princípio comunicativo interativo em relação ao princípio localizacional (BERNSTEIN, 1996), pois define uma assimetria no ensinar-aprender independente de onde ocorre a interação em seu espaço. Neste sentido, o enquadramento forte é valorizado e dominante no ambiente escolar uma vez que o professor assume função ativa no processo de ensino e aprendizado, enquanto que os estudantes têm função passiva.

Há movimentos educacionais que privilegiam o papel do estudante colocando-o como foco do ensinar-aprender. A assimetria de conhecimento entre professor e aluno continua a existir, porém uma nova configuração se estabelece. $\mathrm{O}$ estudante passa a colaborar com a definição das regras de reconhecimento e auxilia a definir os contextos. Contudo, por vezes, o excesso de ênfase na posição ativa do estudante pode provocar uma atenuação da função do professor. Isso porque a educação centrada nos estudantes, quando feita em seu extremo, minimiza o papel do professor que deixa de desempenhar seu papel constituído historicamente, passando a 
ser um mero organizador do material e do espaço. Não há problemas maiores em considerar o aluno como foco. Porém, este não pode ser o único foco provocando o esquecimento e atenuação do papel do professor no ensinar-aprender. Essa atenuação gerou o "fracasso de todas as propostas educacionais em ensino de ciências" (GASPAR, 2005, p.9) focadas exclusivamente no aluno.

Uma leitura possível deste fenômeno, a partir da noção de contexto ora utilizada, é dizer que o enquadramento forte na escola tradicional passou a ser fraco na escola construtivista radical, em intensidade tal que o sistema educacional perdeu seus princípios de regulação e deixou de exercer sua função de ensinar conteúdos científicos e tecnológicos entre outras atribuições.

Uma direção possível para se pensar a educação é não tirar o aluno do foco do ensinar-aprender, mas (re)valorizar o papel do professor, atribuindo papel ativo tanto para o docente quanto para o discente. Desse ponto de vista, ensinar-aprender pode ser pensado como uma construção conjunta de conhecimento e o foco torna-se múltiplo (alunos-professor-aluno). Nesse caso, o professor - enquanto parceiro mais capaz nas práticas escolares - auxilia e aprende com o aluno, que por sua vez, também aprende com seus colegas, implicando regras de enquadramento - intermediárias, não muito fortes nem fracas - atribuindo igual importância aos sujeitos que interagem. Por conseqüência, com a interação mais efetiva dos estudantes, as regras de reconhecimento são definidas por estudantes e professor, propiciando o estabelecimento de contexto nos quais a intersubjetividade pode ocorrer com maior facilidade (uma zona de desenvolvimento proximal mútua).

Para se pensar no estabelecimento de contextos educacionais (sobretudo os formais), além de se referir aos papéis de professor e alunos é importante qualificar quais conhecimentos são ensinados-aprendidos nessas conjunturas. A escola 
privilegia os conhecimentos científicos e tecnológicos, porém o contexto escolar não é constituído puramente pelo ensino formal. O que ocorre é uma mescla do ensino formal e informal. Isso porque há uma aprendizagem mútua na instituição escolar. Além do conhecimento científico, professores e alunos levam os conhecimentos que utilizam no seu dia-a-dia para a escola. Portanto, segundo Bernstein (1996):

[...] as crianças fazem mais do que aprender o que formalmente se espera delas e os professores fazem mais do que ensinar o que formalmente se espera deles. Algumas crianças não aprendem o que é formalmente esperado delas $\mathrm{e}$ alguns professores não ensinam o que é formalmente esperado deles. (p. 20)

Não é o objetivo desta seção discutir o que é educação formal e nãoformal, discutiremos brevemente este assunto na Seção 3.3. Para o momento, assumimos como ensino formal todo aquele que ocorre (ou esperava-se que ocorresse) em uma instituição de ensino regular e ensino não-formal aquele que ocorre fora de tais instituições.

\subsubsection{Relação do Perfil Conceitual e Contexto}

Com a noção de contexto apresentada, podemos fazer a analogia entre significado e zona de perfil conceitual, assumindo que cada zona, como cada significado, será regulada e utilizada de acordo com os mesmos princípios e regras que regulam os significados nos contextos.

Uma visão possível para se pensar o ensino formal é assumir como função desse a conscientização dos aprendizes (e mesmo dos educadores), de quais zonas de perfil conceitual são mais adequadas a serem utilizadas nos diversos contextos estabelecidos no seu dia-a-dia (VIGGIANO \& MATTOS, 2006c). Tal conscientização não deve se restringir aos espaços formais de educação, uma vez que a escola está 
inserida apenas em certo período na vida do indivíduo e, mesmo assim, não estabelece todos os contextos possíveis de serem estabelecidos na vida do estudante.

A construção e aquisição de novas zonas de perfil conceitual ocorrer de forma contextual. Um exemplo de aprendizado contextual é o caso hipotético a seguir. Um brasileiro, que não tem conhecimento da língua alemã, chega à Alemanha e procura conversar em português sobre assuntos da vida cotidiana com um transeunte. Se nenhum dos dois conhecer um pouco da língua do outro, dificilmente estabelecerão uma comunicação plenamente eficiente. São poucas dêixis contextuais disponíveis, o que implica o estabelecimento de um contexto com limitada intersubjetividade. Em outra ocasião, o brasileiro entra em uma padaria e tenta comprar pão, provavelmente este e o atendente alemão chegarão a um entendimento, pois há mais dêixis contextuais disponíveis permitindo, por usa vez,o estabelecimento de um contexto compartilhado com um maior aprofundamento da intersubjetividade.

Como dissemos, Mortimer (1995 e 2000) considera que o contexto influencia na utilização das zonas de perfil conceitual:
A noção de perfil conceitual é, portanto, dependente do contexto, uma vez que é fortemente influenciada pelas experiências distintas de cada indivíduo; e dependendo do conteúdo, já que, para cada conceito em particular, tem-se um perfil diferente. Mas as categorias que caracterizam o perfil são independentes do contexto, uma vez que, dentro de uma mesma cultura, têm-se as mesmas categorias pelas quais são determinadas as diferentes zonas do perfil. (MORTIMER, 2000, p. 80)

Neste trabalho, como já dissemos, consideramos que os contextos são construídos na interação e que essa dinâmica tem escalas diferentes das constituições das zonas de perfil conceitual. Assim, a escala de tempo de aprendizado pode não ser a mesma da mudança dos contextos de vivência dos sujeitos. Em parte isso se deve ao 
fato de que o aprendizado - surgimento de novas zonas ou modificação das préexistentes - ocorre em contextos específicos de aprendizagem, que implicam informação nova e repetição de padrões de estruturas dêiticas.

Do ponto de vista ora assumido, a utilização das zonas não é independente do contexto. Porém, se o indivíduo aprender a usar as zonas somente em alguns contextos similares (e.g. escolares), provavelmente não conseguirá utilizá-las em contextos mais distantes dos contextos formais.

A relação entre zonas do perfil conceitual e seus contextos de uso, exige que, ao realizarmos um levantamento do perfil conceitual, devemos estabelecer o máximo de contextos possíveis para identificar com qual regularidade se utiliza determinadas zonas do perfil estudado.

Por outro lado, além da inclusão do contexto deveríamos também incluir, além da epistemológica e ontológica, a dimensão axiológica. Esta inclusão implicaria em uma dada complexificação do instrumento de medida que não nos atreveremos neste trabalho. Apesar dessa delimitação, sabemos que as dimensões são inseparáveis e mutuamente influenciáveis.

A partir da importância atribuída aos contextos e referindo-se à gênese desses, assumimos que as dimensões estão ligadas às regras de reconhecimento e realização e, portanto, definem o uso de zonas de perfil nos contextos. Logo, a zona eleita para o uso representa a ressonância entre as dimensões do contexto e das zonas de perfil conceitual.

Para exemplificar como uma dimensão está relacionada com a ressonância de uma zona do perfil, tomemos como exemplo o tema da origem das espécies: um grupo de pessoas, ao discutir sobre o tema, pode escolher a idéia 
criacionista ou a evolucionista, entre outras. Apesar de se conceber que existe certa "universalidade" das zonas do perfil conceitual, como proposto por Mortimer (2000), seu acesso dependeria do contexto e das dimensões ontológica, epistemológica e axiológica que cada pessoa atribui a cada zona.

Em um contexto em que a ciência tem um valor mais acentuado que a religião, o indivíduo utiliza a zona evolucionista. Já em um contexto com predominância religiosa (e.g. cristã ortodoxa) sobre a científica, a zona utilizada pode ser a criacionista, dependendo da valoração que o indivíduo atribuiu a cada um dos contextos.

Contudo, um sujeito pode se recusar a utilizar uma determinada zona em função do macro-contexto em que está inserido. Isto é, apesar de estar em um macro-contexto (e.g. universidade), no qual habitualmente outros indivíduos valorizam mais uma determinada zona do perfil (e.g. evolucionista), o sujeito pode não estar enquadrado nesse contexto, usa outros marcas de contexto, assim, utiliza outra zona (e.g. criacionista) que não assumida pela maioria em contexto similares.

De certa forma, o sujeito estabeleceu outro contexto, o qual, caso tenha consciência, estabelece outra valoração para cada uma das zonas. Assim, a zona eleita pode ser diversa da comumente esperada.

Em síntese, com a clareza do contexto, isto é, com as regras de reconhecimento mais bem definidas - como ocorreu no caso do brasileiro na padaria alemã - é possível estabelecer mais facilmente o compartilhamento de significados e logo há entendimento entre os indivíduos.

As regras de realização - que regulam a atribuição de significado juntamente com as regras de enquadramento podem ser interpretadas como 
responsáveis pela definição da prevalência das dimensões, e conseqüentemente pela utilização de uma ou outra zona do perfil conceitual em cada contexto.

Relacionado as regras de reconhecimento e realização com o processo formal de ensinar-aprender, o indivíduo pode perceber que existem zonas de perfil que valorizam o conhecimento científico, sem necessariamente possuí-las. Isto se deve ao fato de que o conhecimento das regras de reconhecimento, apesar de implicar identificação contextual, não implica necessariamente o indivíduo saber qual conhecimento deve utilizar (BERNSTEIN, 1996). Por vezes, isto pode acarretar na dificuldade de resolução do problema, já que o indivíduo sabe que o conhecimento que tem não é suficiente para resolver o problema e deve aprender para poder fazê-lo. Nesse sentido, ele pode perceber que existe outra zona do perfil que ainda não possui que seria mais adequada para aquele contexto.

Logo, tomando a noção de perfil conceitual e olhando na direção do delineamento de contextos, podemos dizer que o contexto é identificado pelo sujeito, mas o indivíduo não sabe qual zona do perfil conceitual utilizar por não possuir a que o próprio considera a mais adequada. Assim, geralmente acaba utilizando a zona mais conhecida, ou seja, uma das zonas prévias do perfil - que foram consolidadas ao longo do desenvolvimento ontogenético do indivíduo - mesmo achando que não é a mais conveniente.

\subsubsection{Algumas considerações: Perfis conceituais e teoria histórico-cultural}

Para estabelecer a relação entre a noção de perfil conceitual e contexto apoiamo-nos na teoria histórico-cultural e na relação entre significado e contexto proposta por Bernstein (1996). Uma idéia central na teoria, e que justifica esta relação, é a de que o "significado da palavra essa unidade [o significado] que reflete da 
forma mais simples a unidade do pensamento e da linguagem" (VIGOTSKI, 2001, p. 398). Assumimos a relação entre significado e contexto proposta por Bernstein (1996) e as noções de significado para Vigotski ${ }^{22}$. É possível relacionar o pensamento do indivíduo e contextos no domínio das funções psicológicas superiores já que a linguagem refere-se a essas. Assim, as palavras - enquanto signos - passam a ter significações determinadas pelo contexto da interação. Nessa direção, Vigotski considera que a variação de contexto acarreta uma variação de sentido (VIGOTSKI, 2001).

Assim como Bernstein (1996), Vygotsky e Luria (1996) qualificam o contexto a partir da interação social e estabelecem a generalizaçã ${ }^{23}$ como sendo o uso de um signo em contexto diverso daquele no qual foi aprendido (VYGOTSKY \& LURIA, 1996).

Entendemos ser possível - por meio de elementos do discurso do indivíduo - caracterizar o perfil conceitual ao identificar a atribuição dos significados das palavras em contextos referentes às zonas do perfil conceitual. Isto é, identificar o uso de uma palavra em diversos contextos, permite extrair informações sobre o perfil conceitual representado por esta palavra. Além disso, o levantamento do uso de outras palavras relacionadas ao perfil conceitual pode auxiliar na identificação de contextos e na definição de zonas do perfil.

Segundo Vigotski (2001, p. 400), há uma generalização inferior e uma superior. A diferença da primeira para a segunda, é que nesta ocorre a expressão dos conceitos abstratos e a mudança do conteúdo concreto da palavra. Associamos a

\footnotetext{
${ }^{22}$ Devido à tradução do russo é possível encontrar diversas grafias para o nome. Optamos por Vigotski (com i) ao longo do texto. Enquanto que nas referências e citações preservamos a grafia presente na obra consultada.

${ }^{23}$ A idéia de generalização nos diversos trabalhos de Vigotski parece ser diferente. Por isto, focamos na obra citada.
} 
forma inferior predominantemente à generalização do homem primitivo, e a superior predominantemente do cultural. Vigotski defende ainda que a palavra é "a generalização nela contida como modo absolutamente original de representação da realidade na consciência" (VIGOTSKI, 2001, p. 407). Ele defende ainda que o significado da palavra é dinâmico, isto é, modifica-se ao longo do desenvolvimento infantil, contudo não podendo ser desvinculado da generalização.

É possível fazermos uma analogia entre perfil conceitual e sentido da forma como proposta por Vigotski (2001)

[Paulham] Mostrou que o sentido de uma palavra é a soma de todos os fatos psicológicos que ela desperta em nossa consciência. Assim, o sentido é sempre uma formação dinâmica, fluida, complexa, que tem várias zonas de estabilidade variada. O significado é apenas uma dessas zonas do sentido que a palavra adquire no contexto de algum discurso e, ademais, uma zona mais estável, uniforme e exata. Como se sabe, em contextos diferentes a palavra muda facilmente de sentido. $\mathrm{O}$ significado, ao contrário, é um ponto imóvel e imutável que permanece estável em todas as mudanças de sentido da palavra em diferentes contextos. (p.465, destaques nossos)

A coleção de sentidos, como expressos na obra de Vigotski (2001), assemelha-se com a noção de perfil conceitual. Um conceito parece possuir vários sentidos possíveis e cada sentido com seu respectivo significado. O sentido relacionase com o contexto e ao significado a ser atribuído naquele contexto, isto é, assemelhase à zona de perfil conceitual. Nesta perspectiva, o significado pode se referir à constituição da zona de perfil conceitual e somente poderá ser identificado em contexto, mesmo que não utilizado. Já o sentido é atribuído de acordo com o contexto, implicando a utilização de seu respectivo significado ou zona estável, como ocorre com a zona de perfil conceitual. 
Até então falamos de significado e generalização segundo Vigotski (2001), cabe destacar que para esse autor

Generalização e significado da palavra são sinônimos. Toda generalização, toda formação de conceitos é o ato mais específico, mais autêntico e mais indiscutível do pensamento. Conseqüentemente, estamos autorizados a considerar o significado da palavra como um fenômeno de pensamento. [...] O significado da palavra só é um fenômeno de pensamento na medida em que o pensamento está relacionado à palavra e nela materializado, e vice-versa: é um fenômeno de discurso apenas na medida em que o discurso está vinculado ao pensamento e focalizado por sua luz. (p. 398)

Neste sentido, Vigotski assume, nesta parte da obra citada, generalização e significado como sinônimos. A partir da relação entre sentido e significado que discutirmos anteriormente, e a noção de perfil conceitual por ora assumida, é possível interpretar a citação de Vigotski, na direção que o significado ou a expressão da zona de perfil conceitual passa a existir independentemente do contexto, contudo, este significado somente pode ser identificado no contexto. Isto é, apesar de existir no pensamento dos indivíduos, os significados assumem função apenas quando são utilizados em contexto. Sem contextos que impliquem a atribuição de um sentido, e seu respectivo significado, não é possível identificar a existência deste.

Realizando um paralelo entre a generalização e as visões de conceitos, percebe-se que as visões clássica, prototípica e por exemplares, por serem baseadas na similaridade, referem-se a um processo mais próximo à linguagem do homem primitivo que do cultural. Isto porque, para expressar qualquer conceito composto é necessário que se faça referência a diversas características de outros elementos, formando um novo conceito. Em contraponto, na visão de perfil conceitual (conceito complexo) pode-se pensar que a partir dos conceitos é possível utilizar 
conceitos mais abstratos e que não precisem explicitamente de um exemplar ou protótipo.

Nesta perspectiva, associamos a atribuição de significado do homem primitivo à limitação de trabalhar com os contextos mais delimitados, enquanto que o homem cultural é capaz de atribuir significados a partir de contextos menos específicos. Refletindo nessa direção, e realizando um paralelo com o trabalho de Bernstein (1996), dependendo da condição social do indivíduo, esse é capaz de utilizar elementos provenientes de contextos mais ou menos específicos.

Apoiamos-nos ainda na teoria histórico-cultural, pois nessa, a linguagem é vista como mediadora e constituidora do indivíduo e da cultura. Além de mediadora na interação, assume também a função de atribuição de significados (VYGOTSKY \& LURIA, 1994). A aprendizagem ocorre com o estabelecimento de uma zona de desenvolvimento proximal (ZDP). Segundo essa idéia, os indivíduos possuem um nível de desenvolvimento real (NDR) - que se refere aos problemas que conseguem resolver sozinhos - e um nível de desenvolvimento potencial (NDP) - que se refere aos problemas que conseguem resolver com o auxílio de outra pessoa. A diferença entre NDR e NDP é chamada de zona de desenvolvimento proximal (VYGOTSKII, 1988; VIGOTSKI, 2001). Após a interação com o parceiro mais capaz, o NDR de cada sujeito se modifica, passando o parceiro menos capaz a conseguir resolver problemas que não conseguia resolver sozinho. É possível, que na interação, professor e aluno estabelecem suas próprias zonas de desenvolvimento proximal, podendo ocorrer uma mudança no nível de desenvolvimento real de ambos, após a interação. Isto é, tanto professor quanto aluno podem aprender a resolver problemas com o outro. Normalmente o professor assume a função de parceiro mais capaz, 
contudo, o aluno também pode assumir esta função em atividades que conhece mais (MENDES \& MATTOS, 2005).

Do nosso ponto de vista, para o estabelecimento da ZDP é necessário que os interagentes se coloquem num mesmo contexto, compartilhando os significados. Logo, ensinar-aprender é necessariamente vinculado à prática sociocultural e a escolha das zonas de perfil conceitual a serem utilizadas ocorre de acordo o conhecimento dos sujeitos, a constituição das zonas de perfil conceitual e o compartilhamento de significados na interação dos indivíduos.

Cabe destacar que a constituição das zonas de perfil conceitual foi realizada pelo indivíduo ao longo do seu desenvolvimento ontogenético. Durante este processo, o indivíduo toma contato com os valores e a ideologia social dominante em sua cultura, aprendendo aspectos ontológicos, epistemológicos e axiológicos (MATTOS et al., 2008). Os contextos, por serem estabelecidos na interação social, também estão impregnados pelos valores culturais, e possuem da mesma forma, cada uma das dimensões. Portanto, a utilização das zonas de perfil depende dos contextos nos quais ocorreram os aprendizados das zonas. A relação entre as dimensões das zonas variam com o contexto, cada uma assumindo maior ou menor importância de acordo com o contexto.

Neste sentido, estratégias de ensinar-aprender com base na noção de Zona de Desenvolvimento Proximal permitem que os indivíduos que interagem, compartilhem seus próprios contextos e significados, possibilitando a modificação na relação de cada uma das dimensões do perfil conceitual. A modificação será realizada de acordo com a relação de cada uma das dimensões dos contextos em que ocorreu a aprendizagem. Em uma situação ideal, quando o sujeito compreende a extensão de suas zonas, consegue perceber a relação das dimensões presentes em cada um dos contextos. 
Isto é, ele aprende quais são as zonas mais adequadas para cada contexto ao verificar quais dimensões prevalecem naquele contexto.

Como dissemos anteriormente, neste trabalho, assumimos como pressuposto que a evolução do perfil conceitual ocorre quando o indivíduo adquire novas zonas ou modifica as pré-existentes e mesmo ou quando modifica o uso das zonas de forma diferente da anteriormente realizada (VIGGIANO \& MATTOS, 2006b, 2006c).

Um exemplo de evolução do perfil conceitual não-intencional é o aprendizado com automatismo de atividades, é o caso de um motorista, que após anos de experiência, não precisa voltar sua atenção completamente para a atividade de dirigir como fazia quando tirou carteira (MATTOS et al., 2008).

Uma possibilidade para a educação formal baseada nas noções de zona de desenvolvimento proximal e perfil conceitual, é a que o professor procure explicitar a utilização das diversas zonas de perfil nos mais variados contextos, auxiliando seus estudantes na escolha das zonas mais apropriadas.

Esta idéia baseia-se na relação entre a generalização e a utilização implícita dos conceitos em contextos, sem necessariamente prender-se à consciência da utilização dos conceitos. Deste ponto de vista, o ensino de ciências pode voltar-se para o compartilhamento de contextos e conceitos e além da conscientização do perfil conceitual proposta por Mortimer (2000).

O professor, enquanto parceiro mais capaz tem na escola o papel de compartilhar conhecimento, trabalhando para que os estudantes - na interação compreendam a utilização das zonas de perfil conceitual em cada um dos contextos. 
Em outras palavras, se pensarmos na Educação em Ciências voltada para ensinar-aprender os conceitos científicos privilegiando a noção de perfil conceitual - na qual conceitos e contextos são indissociáveis - enquanto elemento integrador dos conhecimentos escolares e cotidianos.

Como as zonas de perfil conceitual e os contextos são constituídos a partir das dimensões ontológica, axiológica e epistemológica, o Ensino de Ciências deve se focar nestas dimensões, considerando não só concepções prévias, mas também, valorações prévias de professores e estudantes.

\subsection{Síntese Teórica}

Em síntese, concebemos uma noção de perfil conceitual complexo diferenciada da proposta por Mortimer (1995). Ela baseia-se na visão de conceitos como sistemas complexos, nas idéias de contexto e significado propostas por Bernstein (1996), em idéias de da teoria da psicologia histórico-cultural, sobretudo as presentes nas obras de Vigotski (VIGOTSKII, 1988; VYGOTSKY \& LURIA, 1996; VIGOTSKI, 2001).

No recorte realizado as zonas de perfil conceitual são usadas dependendo do contexto. Este, por sua vez, é estabelecido na interação social. Tanto as zonas de perfil conceitual quanto os contextos, têm dimensões ontológica, axiológica e epistemológica. A predominância das dimensões nos contextos está relacionada com quais zonas de perfil são utilizadas pelo indivíduo. A predominância das dimensões tem origem nos valores culturais do indivíduo, uma vez que este é parte integrante da cultura ou ideologia a qual teve acesso, assim como ocorre a utilização dos signos lingüísticos. Nesta direção, as regras de reconhecimento são estabelecidas a partir dos 
mesmos valores, assim como as regras de realização - que definem qual significado é assumido em determinado contexto.

Portanto, com a noção de perfil conceitual complexo, a noção de evolução do perfil também se modifica. Deixa de ser apenas a inclusão de novas zonas de perfil como propôs Mortimer (2000) e na direção de modificação das zonas préexistentes e da criação de novas (RODRIGUES \& MATTOS, 2007), passando a ser entendida também como da mudança do uso as zonas de perfil em contexto similares.

Concebemos que a Educação em Ciências pode se voltar para o ensinar-aprender focado nas dimensões dos contextos e nas dimensões das zonas de perfil conceitual subsidiando as escolhas das zonas, por parte do sujeito, a serem utilizadas nos contextos de seu cotidiano.

Dada a noção de perfil conceitual complexo - que parte do pressuposto que perfis conceituais se influenciam e que estes são compostos por outros perfis em diversas escalas hierárquicas - e das possíveis formas de ocorrência da evolução do perfil conceitual, torna-se importante o desenvolvimento de métodos para a medição dos perfis conceituais e mesmo da evolução destes. Neste sentido, é relevante o desenvolvimento de pesquisas que valorizem o contexto e a relação entre perfis conceituais relacionados à Educação em Ciências quando focamos a formação de professores. A identificação da relação entre os perfis conceituais podem contribuir para reflexões a serem estabelecidas em cursos de formação de professores e também trazer elementos teóricos e metodológicos pertinentes à medição da relação entre a influência de vários perfis conceituais. 


\section{CAPÍTULO 2:}

\section{PROBLEMA DE PESQUISA}


Partindo do pressuposto de que a forma como professores, ou futuros professores, representam os conceitos relacionados à Educação em Ciências reflete na forma em como trabalham (ou trabalharão) em sala de aula, nos propomos, no presente trabalho, desenvolver uma pesquisa exploratória de conceitos relativos à educação. Neste sentido, assumimos que os indivíduos aprendem/ensinam de diversas formas dependendo do contexto estabelecido. Para isso, optamos utilizar a noção de perfil conceitual, conforme apresentada na Seção 1.4. Essa noção serve como ponto de partida para entendermos como os conceitos de ensinar e aprender são utilizados pelos professores de Física em formação em diferentes contextos.

Um pressuposto que assuimos nesta pesquisaé que os licenciandos em Física possuem perfis conceituais de ensinar e de aprender, e que de alguma forma pode ser medido.

Dessa forma, na presente pesquisa, temos como objetivo a construção de um instrumento para o levantamento dos perfis conceituais de licenciandos em Física acerca dos conceitos ensinar e aprender.

Esperamos que o desenvolvimento de instrumentos de medição de perfis conceituais de conceitos relacionados à Educação possa contribuir futuramente com o planejamento e desenvolvimento de cursos de formação de professores, seja no planejamento curricular, seja na problematização do conteúdo de Física e de Educação em Física. Esperamos, também, que o conhecimento dos perfis conceituais relacionados com a Educação Científica auxilie na percepção da prática docente como atividade interdisciplinar, constituída a partir de diversos saberes (e.g. psicologia, filosofia, epistemologia, didática) e não somente do conteúdo específico. 
Acreditamos que ao sair do âmbito de pesquisa para a formação de professores, a noção de perfil conceitual pode contribuir para a reflexão dos indivíduos sobre como e o que pensam e, também, como utilizam o conhecimento no seu cotidiano. Estamos certos de que não basta o indivíduo/educador saber que possui um perfil conceitual sobre um determinado conceito, mas que seja capaz de utilizar criticamente cada uma de suas zonas nos diferentes contextos.

Assim, concebemos uma formação que privilegie o conhecimento, por parte do indivíduo, sobre seu perfil conceitual. Portando, ao realizar uma pesquisa diagnóstica, com instrumentos adequados para o levantamento dos perfis conceituais, esperamos poder subsidiar futuras intervenções ou planejamentos que procurem contribuir para a Educação em Ciências.

Considerando-se as limitações dos métodos (Seção 1.2.2) existentes para o levantamento de perfil conceitual, verificamos a necessidade de se conceber um instrumento que considere, simultaneamente, zonas dos perfis de ensinar e de aprender e seus contextos de uso.

Para tanto, escolhemos construir um questionário auto-administrável, que possibilita a aplicação sem a presença do pesquisador (BABBIE, 2003), como instrumento de medida dos perfis conceituais de ensinar e de aprender. Além disso, o questionário permite que, depois de definido o método de análise para uma determinada amostra, a pesquisa seja replicada com outras amostras de forma mais simples.

A presente pesquisa tem por foco específico, o desenvolvimento e a validação do questionário, não tendo por objetivo esgotar todas as características dos perfis conceituais de ensinar e de aprender ou de conceitos relacionados à Educação Científica. 


\subsection{Perguntas de Pesquisa}

Construímos algumas perguntas de pesquisa que apresentamos a seguir. Estas perguntas são de caráter qualitativo, e tangem questões relativas à constituição dos perfis conceituais de ensinar e de aprender, os contextos de uso das zonas de perfil e a relação entre os perfis conceituais de ensinar, aprender, ensinar física e aprender física.

Apresentaremos a seguir as perguntas de pesquisas acompanhadas de um breve comentário para deixar claros os objetivos que levaram a sua proposição.

\section{Pergunta 1: Os enunciados das questões, em um questionário, são capazes de delimitar determinados contextos?}

Como dissemos no Capítulo 1 a delimitação de um contexto ocorre na interação, através de elementos presentes na comunicação. Por este motivo, pode-se procurar avaliar se o enunciado de uma questão é delimitador de certos contextos controlados. Isto é, tentamos verificar se o enunciado consegue estabelecer as regras de reconhecimento, enquadramento e realização que implicam o uso de uma ou outra zona de perfil conceitual.

Em trabalhos anteriores (VIGGIANO \& MATTOS, 2007) identificamos que duas questões com enunciados muito parecidos, isto é, com apenas uma palavra de diferença levou a respostas muito diferentes. Logo, a categorização das respostas de cada uma das questões foi muito diferente. Isso indica que a mudança de apenas uma palavra é suficiente para modificar as regras de realização, reconhecimento e enquadramento.

A partir desse indício, procuramos propor questões semelhantes para tentar identificar/controlar o estabelecimento de contextos distintos. 


\section{Pergunta 2: Há uma relação entre as zonas dos perfis conceituais de ensinar e aprender?}

Esta pergunta foi proposta baseada no modelo de perfil conceitual complexo, pois acreditarmos na existência um perfil conceitual hierarquicamente superior aos perfis de ensinar e de aprender que englobe estes. Apesar de inexistir, muitas vezes no discurso cotidiano, a vinculação entre os conceitos de ensinar e aprender, existem alternativas teóricas que concebem a educação na perspectiva da relação entre esses dois conceitos, como discutido no próximo capítulo.

Deste ponto de vista, é possível identificar alguns estudantes da amostra que concebem uma relação entre os perfis conceituais de ensinar e de aprender, mesmo que isso se restrinja a apenas a alguns contextos. Isto é esperado tento em vista que, ao assumirmos a noção de perfil conceitual, não concebemos que exista apenas uma representação de ensinar e aprender, mas sim uma pluralidade de representações, que são utilizadas contextualmente.

Posteriormente discutiremos como algumas das categorias assumidas neste trabalho podem influenciar no estabelecimento das zonas de perfil e como outras podem definir o contexto. É relevante destacar que em alguns momentos, as zonas de perfil e os contextos de usos se identificam de tal forma que chegam a ser indissociáveis. Isso ocorre, pois as constituições de zonas de perfil, em contextos específicos, são realizadas a partir da predominância das dimensões ontológica, epistemológica e axiológica. Os vínculos entre os conceitos e os contextos podem ser redundantes, principalmente porque todo aprendizado ocorre contextualmente, e somente em casos específicos é possível medir se um sujeito é capaz de identificar a zona de perfil que possui e os contextos nos quais a utiliza.

Apesar da hipótese de trabalho da Pergunta de Pesquisa 1, não esperamos que todas as questões delimitem um contexto identificável, mas que permitam ao respondente do 
questionário estabelecer contextos específicos, manifestando-o em sua reposta. Neste sentido, podemos fornecer mais ou menos elementos para que os licenciandos ora assumam um contexto mais próximo do que idealizamos, ora assumam os que lhe pareçam mais razoáveis ou adequados. Acreditamos que um questionário que nos permita analisar as relações entre os perfis deve definir contextos semelhantes para que possamos avaliar a relação entre os perfis conceituais e os contextos de uso das zonas dos perfis.

Ao explorarmos diversos contextos é possível verificar como as zonas de perfis conceituais são utilizadas em contextos semelhantes. Assim, se assumirmos a hipótese que as zonas de dois perfis relacionam-se, é possível avaliar como se dá a relação entre os perfis.

Caso exista alguma relação entre as zonas dos perfis de ensinar e de aprender, obteremos indícios da existência de um perfil conceitual - de ensinar-aprender - mais amplo e hierarquicamente superior que englobaria tais perfis conceituais.

\section{Pergunta 3: Qual é a relação entre os perfis conceituais de ensinar, de aprender e de ensinar-aprender?}

Nesta pergunta partimos do pressuposto de que existe um perfil conceitual hierarquicamente superior que se refere a macro-contextos, também hierarquicamente superiores, que englobam os contextos específicos de uso de cada um dos perfis que compõem perfil mais amplo e complexo. O principal objetivo desta pergunta é verificar como ocorre a utilização das zonas de cada um dos perfis conceituais - de ensinar, de aprender e de ensinaraprender - em contextos específicos, verificando suas relações.

Para responder a esta pergunta, comparamos as respostas obtidas com o instrumento e as categorizações de questões. 
Para tanto, utilizamos análise estatística para identificar padrões e correlações entre as categorizações das respostas de cada uma das questões do questionário. Os métodos estatísticos possibilitam aferir até que ponto as categorizações de cada uma das perguntas estão correlacionadas. No caso de não conseguirmos verificar uma correlação entre questões que julgamos estabelecer contextos semelhantes, podemos verificar a ausência ou a fraca ligação entre os perfis conceituais em tais contextos.

Os indícios da relação entre zona de perfil conceitual e contexto podem ser representados como um espaço complexo, no qual diversos elementos (perfis conceituais) estão conectados com vários outros. Por isto, utilizamos uma ampliação da visão de conceitos como rede - a noção de perfil conceitual complexo discutida na Seção 1.3. Cada conceito possui sua própria rede de conceitos relacionados e, em particular, os perfis conceituais de ensinar e de aprender possuem conexões nessa rede de representação. Tais conexões somente podem ser identificadas em certos contextos.

\section{Pergunta 4: É possível verificar se os licenciandos alternam suas posições de professor e aluno conforme a questão?}

Essa pergunta se sustenta na hipótese de que os professores em formação olham para o sistema educacional através de duas perspectivas diferentes. Quando estão na condição de alunos, assumem zonas de ensinar e aprender diferentes de quando estão na posição de professor.

A verificação dessa mudança de posição implica a inclusão de questões sobre ensinar e aprender que remetam os estudantes à contextos semelhantes, porém com posições distintas, ou seja, de professor ou aluno. Com isso, caso manifestem (ou não) diferentes zonas do perfil, poderemos obter os indícios procurados. 
Na verdade, a expectativa da mudança de posição baseia-se na proposta de um curso de licenciatura, i.e., esperamos que os estudantes, ao longo do curso, possam sair da posição de alunos para a posição de professores.

Em trabalhos anteriores (VIGGIANO \& MATTOS, 2006b), identificamos que as repostas desse tipo de amostra, mudam de categoria, em particular em duas questões, cujos enunciados diferiam apenas pela substituição da palavra ensinar pela palavra aprender. Nestas respostas, observamos que ao se referirem a ensinar, os respondentes não eram coerentes ao se referirem ao aprender, e vice-versa. Uma interpretação possível é que conforme a questão, os indivíduos poderiam se colocarar em uma das duas posições, seja de professor ou aluno.

\subsection{Construção de questionários}

Com a finalidade de identificar as idéias dos estudantes há vários testes de diagnóstico conceitual (e.g. HESTENES \& WELLS, 1992; HESTENES et al., 1992; LIGHTMAN \& SADLER, 1993; RUSSELL, 1994; ODOM \& BARROW, 1995; WANDERSEE et al., 1994; TREAGUST, 1988; ZEILIK et al., 1997; BISARD \& ZEILIK, 1998; HAKE, 1998; ZEILIK et al., 1998). Porém, estes são construídos com a finalidade de identificar as concepções alternativas ou científicas dos indivíduos e não seu perfil conceitual.

Apesar da revisão e avaliação dos testes para levantamento das concepções alternativas, esses não se mostraram convenientes para o levantamento dos perfis conceituais. Isso porque, quando muito, seriam convenientes apenas para realizar o levantamento das zonas de perfil desconsiderando os contextos. Além disso, como vários desses testes são baseados em questões fechadas de múltipla escolha, não há possibilidade de identificação de outras zonas de perfil não identificadas previamente. Daí a escolha por uma pesquisa exploratória, pois a análise 
de alguns elementos discursivos dos estudantes se faz relevante, afinal é nele que se manifestam explicitamente as relações entre zonas de perfil conceitual e contexto.

Para a construção dos questionários, tanto para o questionário piloto quanto o final, optamos por construir questões abertas curtas simples (BABBIE, 2003). Segundo Babbie (2003), uma questão simples possui apenas uma pergunta por enunciado, diminuindo a chance de confusão do respondente ao ler o enunciado. Para ficar claro o que é uma questão simples, apresentamos para contraste um exemplo de uma questão composta, a qual pode facilmente levar o indivíduo à dúvida: "Você concorda que o governo brasileiro invista mais em educação e que use o dinheiro da Saúde para isso?". Fica claro que o respondente pode considerar que é importante investir mais em educação, porém pode discordar da utilização da verba da Saúde para tal fim. Portanto o enunciado conta, efetivamente, com mais de uma pergunta. Para evitar a criação de questões complexas procuramos evitar a utilização da conjunção "e" (ZEILIK, 2005).

Além disso, nos focamos na construção de questões curtas de modo que "o respondente deve poder ler um item rapidamente, entender sua intenção, e escolher ou dar uma resposta sem dificuldades" (BABBIE, 2003, p.193). Ao utilizar esses tipos de questões, percebemos três aspectos positivos, o primeiro é a diminuição do tempo de resposta dos questionários, o segundo aspecto é conseqüência do primeiro e relaciona-se ao aumento do número de questões completamente respondidas. O terceiro aspecto é uma maior facilidade na categorização, uma vez que enunciados sintéticos geram menos diversidade de categorias simultâneas em uma mesma resposta. Uma desvantagem causada por respostas curtas, é que essas podem não revelar completamente a intenção do sujeito naquele contexto.

Utilizamos procedimentos sugeridos por Babbie (2003) para realizar a formatação do questionário. O primeiro deles é o de colocar apenas uma pergunta por linha, com 
o objetivo de evitar que o estudante deixe de responder alguma pergunta. Delimitamos o espaço de resposta aplicando margens para evitar que os estudantes dediquem muito tempo a poucos itens e deixem de responder outros, além de impedir que a resposta torne-se muito longa e que acabe por levar o respondente a sair do contexto proposto na questão.

É relevante destacar que apesar de podermos identificar várias zonas de um perfil conceitual em um grupo de indivíduos, nem todos os indivíduos possuem todas as zonas do perfil conceitual.

É importante, ao se construir um questionário para o levantamento de perfil conceitual, não utilizar ordem aleatória para as questões. Esse cuidado deve ser tomado para evitar indução nas respostas, uma vez que se apresentarmos um contexto mais específico, e depois realizarmos uma pergunta que o remeta a um contexto mais geral, podemos induzí-lo a responder de acordo com o contexto mais delimitado. Por isso, é recomendável, sempre que possível, partir de questões com contextos menos específicos para as questões de contexto mais definido. Como, por exemplo, usarmos as questões na seguinte ordem: “Como se aprende?"; “Como se aprende a jogar futebol?”. Os respondentes provavelmente procurarão responder à pergunta mais geral, estabelecendo um contexto que lhe é mais significativo e, quando perguntados sobre como se aprende a jogar futebol, procurarão responder de acordo com o contexto da atividade. Porém, se fizermos o inverso, ao responder sobre como se aprende em um contexto menos definido logo após a questão mais específica, os respondentes podem responder à questão mais geral tendo presente a forma como responderam ao contexto mais específico, como é o caso de como se aprende a jogar futebol, sendo menos provável o estabelecimento de outros contextos. Outra opção seria aumentar o número de contextos mais específicos. Esta opção implicaria o aumento da extensão do questionário, dificultando a coleta e a análise de dados. 


\subsection{Questionários para medição de perfis conceituais}

O questionário, que propusemos para o levantamento dos perfis conceituais, foi construído no sentido de minimizar o tempo de coleta de dados por indivíduo. Além disso, deve ser suficientemente amplo e profundo para expressar o perfil conceitual dos estudantes e sua relação com os contextos de utilização. Como discutimos no CAPÍTULO 1:, os trabalhos que propõem metodologias para medição de perfil conceitual, em sua grande maioria, não levam, em conta os contextos de utilização das zonas de perfil, durante a elaboração das $\underline{\text { mesmas. }}$ Destacamos ainda, que apenas o levantamento das zonas limita os aportes trazidos pela noção de perfil conceitual, o que os torna os instrumentos muito próximos daqueles utilizados em certos trabalhos de identificação de concepções alternativas.

Assim, a metodologia de coleta de dados via questionário auto-administrável (BABBIE, 2003), se mostra mais adequada aos moldes desta pesquisa. Principalmente pelo fato de que pretendíamos trabalhar com uma amostra final de uma turma da licenciatura em física da USP, que geralmente possui entre 30 e 60 estudantes. Se realizássemos entrevistas, o volume de dados seria excessivamente complexo para as pretensões do tema de um mestrado.

Neste trabalho, como já dissemos, assumimos que o ponto fundamental para a construção de instrumentos de medição de perfil conceitual é a consideração da estreita relação entre contexto e perfil conceitual. Portanto, o instrumento proposto deve ser capaz de delimitar alguns contextos, e ao mesmo tempo, permitir que se revelem outros não considerados a priori.

Esperamos que, através de elementos textuais presentes em cada questão, o indivíduo identifique as regras de reconhecimento, de realização, de enquadramento, princípios comunicativos etc., de forma a ser remetido aos contextos que desejamos (Pergunta de Pesquisa 1). Portanto, pretendemos fornecer elementos dêiticos que possibilitem o delineamento 
de alguns contextos semelhantes aos que pretendíamos estudar. É dessa forma que pretendemos incitar os estudantes a utilizarem diferentes zonas de perfil conceitual.

Nesse sentido, algumas questões são mais abertas, isto é, possuem contexto menos delimitado, permitindo ao respondente utilizar a zona do perfil conceitual que tenha maior intensidade de representação na situação apresentada, o que pode nos remeter a contextos não categorizados a priori.

Para a coleta de dados optamos por construir dois questionários, um piloto, aplicado em 2005 e um final, aplicado em 2006, fruto da análise do questionário piloto e dos aportes teóricos obtidos com o levantamento bibliográfico (em síntese no CAPÍTULO 3:). A análise do questionário piloto, inclusive a validação de algumas das categorias de construção das perguntas encontra-se no Apêndice A. A discussão sobre o questionário final (simplesmente chamado de questionário) e sua análise será feita no CAPÍTULO 4:. Aqui nos ativemos apenas à discussão sobre pressupostos que utilizamos para sua construção.

A ausência de referências sobre a construção de questões delimitadoras de contexto fez com que propuséssemos algumas categorias a priori para sua construção. Criamos questões contextualizadas, as quais representassem uma ou mais das categorias escolhidas.

Para permitir o surgimento de indícios das zonas de perfil, ou seja, de seus contextos, além de contar com categorias a priori, é necessário que o instrumento seja suficientemente flexível. Assim, o instrumento dever oferecer referentes mais específicos de contextos, realizando a delimitação dos mesmos e apresentando, também, referentes mais gerais de modo a permitir que o próprio indivíduo delimite ou escolha o contexto que lhe convém. Procuramos desenvolver um instrumento com o qual se captasse a complexidade da relação entre zonas de perfil conceitual e contexto. 
As categorias de construção do questionário piloto diferem das categorias do questionário final. Isto se deu devido ao aprofundamento teórico realizado com o levantamento bibliográfico sobre os conceitos de ensinar e aprender e à análise do questionário piloto. Assim, se mostrou mais proveitoso modificar algumas categorias iniciais. Discutiremos as categorias no próximo capítulo. 


\section{CAPÍTULO 3:}

\section{ENSINAR E APRENDER}


Neste capítulo, desenvolveremos um breve apanhado sobre os conceitos ensinar e aprender. Optamos, portanto, por fazer um levantamento bibliográfico sobre tais conceitos, procurando estabelecer relações entre as visões, como uma primeira aproximação da dimensão ontogenética destes conceitos. A revisão tem por objetivo a identificação e caracterização de categorias que possibilitem o estabelecimento das zonas de perfil e alguns contextos de utilização destas. Neste sentido, cada uma das seções deste capítulo refere-se à respectiva dimensão esquema representado na Figura 3. Este esquema serve para auxiliar a criação de questões delimitadoras de contexto a serem utilizadas no questionário final. A dimensão concepções de educação caracterizou as zonas de perfil que assumimos neste trabalho, enquanto que as outras dimensões referem-se, principalmente, ao estabelecimento dos contextos de uso das zonas.

\subsection{Concepções de Educação}

Nesta seção discutiremos algumas visões sobre os conceitos de ensinar e aprender existentes na pesquisa em Ensino de Ciências e em Educação. Não nos focamos em uma análise histórica dos conceitos. Isto porque acreditamos que os principais modelos de ensinar e aprender, difundidos na cultura contemporânea, se referem aos modelos consolidados no Século XX. Por vezes, as visões de ensinar e aprender, e mesmo de educação, são caracterizadas com base na argumentação a favor ou contra alguns de seus procedimentos e métodos. Isto porque, alguns autores criticam mais as formas de ensinar/aprender, propondo sua manutenção ou alternativas. Em alguns casos os autores deixam claros seus os pontos de partida na psicologia e na filosofia. Em outros, apesar de assumirem uma base nesses ramos do conhecimento, não o explicitam. Como pôde ser entendido segundo a noção de perfil conceitual (CAPÍTULO 1:), algumas visões de ensinar e aprender, não são necessariamente excludentes, e podem ser até identificadas como 
complementares, sobretudo quando há modificação das propostas educacionais ao longo do tempo.

Dependendo do conjunto de autores, há dificuldades na tradução de alguns termos do inglês. Por exemplo, ora os termos "learning" e "teaching" são utilizados para se referir à "aprendizagem/aprendizado" e ao "ensino" e ora para se referir ao "ensinar" e "aprender". Para reduzir as incertezas das traduções e caracterizar ensinar e aprender procuramos inferir, no contexto do texto, qual sentido utilizado pelo autor, e qual a respectiva tradução que parecia ser a mais adequada.

A relação entre ensinar e aprender conhecimento vem sendo explorada em vários trabalhos, em ambientes de aprendizagem - por vezes chamados de contextos de aprendizagem -, em metodologias de ensino e em abordagens de ensino-aprendizagem.

\subsubsection{Algumas visões de Educação na literatura de Ensino de Ciências}

Lemke (2006) propõe algumas metas para a Educação Científica, sobretudo na direção da mudança de como os estudantes interagem com o objeto educativo. Aqui destacamos aspectos das duas visões de ensinar apontadas no trabalho.

O primeiro se refere a uma Educação Científica claramente segmentada de acordo com a idade dos estudantes, pouco contextualizada com seu cotidiano, implicando conhecimentos abstratos e desvinculados das questões tecnológicas e históricas, além do tratamento superficial do conteúdo e da utilização de problemas artificiais. Além disso, os aspectos emocionais e afetivos são desconsiderados.

O segundo aspecto, em contraponto, se refere a uma Educação Científica sem divisão rígida de idade, contextualizada nas questões sociais cotidianas dos estudantes, com a valorização dos conhecimentos relacionados ao sujeito, às injustiças sociais e questões 
ambientais. Tal modelo busca reorientar os valores da Educação, da Ciência e da Tecnologia para a resolução de problemas ligados à cidadania. Ainda, nesse segundo modelo, o autor se refere a uma Educação na qual os estudantes podem ter uma atuação mais colaborativa e igualitária com os professores, devendo ser incentivados a desenvolverem habilidades de juízo e aprendizagem independente.

Outros autores que procuram tecer algumas reflexões sobre os processos educacionais são Campanario e col. (1999). Os autores criticam uma das visões de Educação Científica amplamente difundida, na qual o "processo de ensino-aprendizagem se reduz a uma simples transmissão e recepção de conhecimento elaborado" (Campanario et al. 1999, p.2), o que é chamado de aprendizagem receptiva e repetitiva. Em contrapondo propõem visões alternativas. A primeira, baseada na teoria de Piaget, é a aprendizagem por descobrimento, na qual os estudantes são levados a atuar ativamente, tendo por base os métodos da Ciência. Tal modalidade de aprendizagem implica um ensino baseado na proposição de questões abertas, que permitam aos alunos construírem os princípios e leis científicas a partir da própria prática, o que, segundo os autores, seria mais motivante. Ainda segundo os autores, no modelo baseado na descoberta o estudante é considerado como o responsável por sua própria aprendizagem.

Para Campanario et al. (1999), o ensino por problemas é outro modelo de educação difundido na Educação em Ciências. Os problemas nesta proposta podem ser experimentos simples, tarefas de classificação, conjuntos de observações, questões abertas entre outros. Os problemas são utilizados na atividade didática para orientar e propiciar que o estudante aprenda os conteúdos e conceitos presentes no currículo escolar a partir de várias fontes. Apesar da importância da prática de resolução de problemas para a compreensão dos conceitos a serem ensinados-aprendidos, esta não tem o papel de levar os estudantes ao descobrimento dos conceitos científicos, mas sim de levá-los a destacarem os elementos importantes dos conteúdos curriculares. 
Campanario et al. (1999) defendem ainda que o ensino por problemas, assim como o modelo de aprendizagem por descobrimento, atribui ao estudante grande parte da responsabilidade da aprendizagem. Contudo, o professor assume papel importante, sendo o responsável pela seleção dos problemas adequados, da organização e ordenação do processo educacional e dos objetivos a serem atingidos. É o professor quem deve procurar avaliar a motivação e as atitudes dos estudantes.

Uma dificuldade encontrada no ensino por descobrimento e aprendizagem por resolução de problemas, é a resistência do estudante em deixar a função passiva de receptor de conhecimento e assumir uma posição ativa.

O modelo cognitivo explorado pelos autores é o da mudança conceitual, o qual é considerado basilar para propostas construtivistas de ensino-aprendizagem (CAMPANÁRIO et al., 1999). Apesar da importância desse modelo, nos limitamos a destacar, nesta seção, que durante o processo de ensino-aprendizagem, os estudantes devem ser levados a substituírem suas concepções alternativas por concepções científicas. Discutimos mais expressivamente sobre as propostas que constituem o movimento de mudança conceitual na Seção 1.1

Os exemplos de visões de ensino e aprendizagem apresentados até o momento pressupõem que as propostas educacionais nem sempre são excludentes, sendo algumas complementares a outras, com veremos a seguir.

Um exemplo de utilização simultânea dos aspectos apresentados anteriormente, é o ensino por investigação dirigida, que utiliza situações problematizadoras como ocorre no ensino por problemas - com o objetivo de promover uma mudança conceitual. Nesta modalidade de Educação, o desenvolvimento dos estudantes ocorre, basicamente, com o enfrentamento de uma situação problematizadora que é motivadora, a qual é resolvida com trabalhos em grupo com base em referências bibliográficas 
(CAMPANÁRIO et al., 1999). Os estudantes devem seguir o que os autores chamam de uma “orientação científica". Nela os estudantes devem resolver os problemas "com proposição de hipóteses (e emissão as idéias prévias), elaboração de estratégias possíveis de resolução e análises e comparação com os resultados obtidos por outros grupos de alunos" (CAMPANÁRIO et al., 1999, p. 186).

Os autores propõem, também, que deve haver um momento no qual sejam apresentadas novas situações para se deixar mais claras as relações entre Ciência, Tecnologia e Sociedade. Um elemento marcante desta proposta de ensino é a necessidade de atividades de síntese, que gerem um produto final de aprendizagem. Da mesma forma que o ensino por problemas e a aprendizagem por descobrimento, o ensino por investigação minimiza a pura recepção de conhecimento, propondo uma postura mais crítica e ativa dos estudantes no processo de ensino-aprendizagem.

Um destaque histórico acerca das visões de ensinar e de aprender é o modelo difundido nas décadas de 1960, 1970 e 1980 que, segundo Kubo e Botamé (2001), se caracterizou como o ensino personalizado, individualizado ou programado, o qual se baseava nas idéias de Skinner e Pavlov. Neste modelo o ensinar está vinculado ao aprender, assim como à verificação da aprendizagem. Além disso, ensinar se relaciona com o comportamento do professor e aprender com o do aluno, deixando claro que o inverso não está contemplado, ou seja, o aluno não ensina e o professor não aprende. O preenchimento de lacunas em frases e a repetição massiva de exercícios semelhantes são predominantes. O professor assume papel de organizador do processo educativo, tendo a função de distribuir materiais e aplicar a avaliação (GASPAR, 2005) 
Nessa época, alguns autores procuravam construir modelos de ensino e aprendizado que pudessem ser caracterizados por critérios mais gerais, como aponta o trabalho de Säljö (1979). Neste trabalho o autor propõe cinco formas básicas de conceber a aprendizagem:

a) aumentar conhecimento;

b) memorizar ou reproduzir;

c) aplicar;

d) entender;

e) procurar/olhar algo em uma perspectiva diferente.

Marton et al. (1993 e 1997), em complemento a essas formas, incluem ainda uma sexta:

f) mudar enquanto pessoa.

Marton et al. (1997, p. 29) identificaram outras possibilidades de categorização, a partir de categorias prévias de aprender, entre elas:

a) memorizar (palavras);

b) memorizar (significado);

c) entender (significado);

d) entender (fenômeno).

O aprendiz "pode ser ensinado" ou "aprender por algo feito por si mesmo", gerando uma incerteza sobre quem é o agente principal do processo (professor ou aluno). A partir das diversas visões identificadas de aprender, os autores propõem três fases de aprendizado que ocorrem seqüencialmente: 
1ª Fase: fase de aquisição de conhecimento: memorizar (ou reproduzir) e entender ou procurar algo numa perspectiva diferente;

$2^{\text {a }}$ Fase: fase de conhecimento: é aumentar conhecimento ou mudar enquanto pessoa;

$3^{\text {a }}$ Fase: fase de utilização: aplicar ou aplicar e procurar algo numa perspectiva diferente.

Para Marton et al. (1993 e 1997), a aprendizagem é um processo que ocorre em certa seqüência. Contudo, não ocorre sempre da mesma ordem.

Segundo Marton et al. (1997), é possível realizar dois agrupamentos destas formas:

i) Abordagem superficial: (a) por aumentar o conhecimento, (b) memorizar e (c) aplicar

ii) Abordagem profunda: b(d) entender, (e) procurar algo em outra perspectiva e (f) modificar-se enquanto pessoa.

A superficialidade e profundidade, relativa aos agrupamentos, referem-se a como é estabelecida a relação entre os aprendizes com o que aprendem e com quem ensina. Considera-se que o indivíduo quando assume papel mais ativo é uma abordagem profunda e, por outro lado, é superficial quando o indivíduo atua passivamente.

Duarte (2007) relata que alguns autores relacionam a abordagem superficial com uma visão quantitativa e relacionam a abordagem profunda com uma visão qualitativa. Além disso, este autor relata que é possível que haja alternância do uso das abordagens em função do contexto.

Partindo dos trabalhos de Marton et al. (1997) e Säljö (1979), Entwistle e Peterson (2004) apresentam, além das visão e abordagem profunda e superficial, a 
abordagem estratégica. Enquanto a abordagem profunda foca-se na busca pelo significado e a superficial na transmissão do conhecimento, na estratégica procura-se promover um estudo organizado do conteúdo a ser estudado. A intenção, neste caso, é atingir os objetivos pessoais do estudante e do curso, valorizando a auto-regulação por parte do sujeito, o qual aprende ao organizar completamente autonomamente seu estudo, gerenciar e cumprir prazos procurando se concentrar no trabalho. Além disso, em tal abordagem presume-se ser necessário ter consciência de que a aprendizagem ocorre em contextos. Nesse sentido, o indivíduo deve ser capaz de avaliar os critérios e necessidades, distinguir as formas efetivas para estudo, reconhecer sua própria responsabilidade e as dos outros. Entwistle e Peterson (2004) defendem que os extremos das abordagens de aprender/aprendizagem - ainda que o caminho ou o processo para se atingir esse produto não seja o mesmo - acabam levando aos mesmos níveis de entendimento, isto é, independentemente do processo o produto é o mesmo.

Para Entwistle e Peterson (2004), o conceito de ensino se relaciona às visões de aprendizagem e de conhecimento dos indivíduos evolvidos no processo educativo e às abordagens de ensinar e aprender. Estes autores defendem que as experiências prévias dos indivíduos influenciam como estes processos de ensinar e aprender ocorrem. Neste sentido, qualificam dois tipos de ensino:

a) abordagens orientadas para o aprendiz e sua na aprendizagem;

b) e outra orientada para o ensino e que se refere à transmissão de conhecimento.

Purdie e Hattie (2000), também ampliando os trabalhos de Marton et al. (1997) e Säljö (1979), distinguem duas concepções de aprendizagem com base em uma dimensão social. A aprendizagem pode ser vista como "obrigação moral" e como “desenvolvimento de competência social". Os autores propõem nove visões de aprendizagem que se referem ao indivíduo: 
a) ter um aumento de conhecimento;

b) memorizar ou reproduzir uma informação;

c) utilizar a informação com um fim;

d) ter entendimento;

e) ver algo de forma diferente;

f) ter realização pessoal;

g) ter uma obrigação;

h) ter um processo não limitado por tempo ou contexto;

i) desenvolver uma competência social.

As diferenças deste trabalho para os anteriores podem ser identificados nas letras c, e, f, g, h, e i. e relaciona-se à inclusão de questões subjetivas atreladas à motivação.

Da mesma forma, a partir do trabalho de Marton et al. (1999), Bunker e Katitjin (1999) propõem outras visões de aprendizagem, como Purdie e Hattie (2000), incluindo aspectos motivacionais e ainda aspectos de desenvolvimento psicológico e culturais. Nesta perspectiva aprendizagem pode ser categorizada como:

a) aprendizagem por obrigação;

b) aprendizagem é aprender ${ }^{24}$;

c) aprender fazendo;

d) aprendizagem é conseguir saber coisas difíceis;

e) aprendizagem é compreender.

\footnotetext{
${ }^{24}$ Fica evidente a questão lingüística na expressão original: “learning is to learn” (BUNKER \& KATITJIN, 1999, p. 2).
} 
Uma categorização que foi amplamente difundida e gerou um testeinventário para levantamento das visões de ensinar foi proposta por Meyer e Boulton-Lewis (1997). Para estes autores, as concepções ligadas à aprendizagem podem ser sintetizadas em:
a) acumulação de fatos;
b) ver coisas diferentes;
c) obrigação;
d) coleção de fatos;
e) crescimento de conhecimento.

Passmore (1980) discute que o ensino pode ser concebido de duas maneiras diferentes, a primeira, apenas ocorre ensino se o estudante aprendeu efetivamente. A outra é desvincular ensino e aprendizagem. Logo, alguém pode ensinar, mesmo que ninguém aprenda. Isto significa que o objetivo do ensino é promover a aprendizagem, independentemente de que ocorra aprendizado (PASSMORE, 1980; HIRST, 1971). Para Passmore (1980), dependendo do contexto pode-se assumir uma das duas visões de ensinar. Um exemplo que evidencia as duas possibilidades de uso pode ser identificado ao verificarse a ironia presente na frase "ele ensinou-me a nadar e, por isso, naturalmente, não sei nadar" (PASSMORE, 1980, p.20). O autor caracteriza ainda que o ensino pode ser autoritário ou pode "respeitar a integridade do aluno" (PASSMORE, 1980, p.19). O conceito educação, segundo o autor, por vezes se confunde com o de ensino. Percebe-se que isto complica ainda mais a compreensão do que é o ensino já que o termo "educação" pode ser utilizado em vários sentidos, como por exemplo: uma pessoa escolarizada, uma pessoa que tem princípios morais claros ou como uma pessoa culta.

A tese central do trabalho de Passmore (1980) consiste numa relação triádica entre, alguém que ensina algo a outro alguém. Assim, não faz sentido se falar em 
ensino se não há alguém que ensina, se não há um objeto a ser ensinado e também uma pessoa para aprender. Com a exaltação deste ponto de vista o autor valoriza o ensino focado na aprendizagem efetiva, já que tentar ensinar não implica, necessariamente, consideração do aprendiz. E o que é ensinado pode não ser necessariamente o aprendido. Apesar disso, é possível se referir ao ensino enquanto atividade profissional de um indivíduo: "ele ensina aritmética” (PASSMORE, 1980, p.22). Para Passmore (1980), o ensino é uma atividade universal e não exclusiva dos professores, podendo ser exercida por qualquer pessoa. Contudo, somente é possível ensinar o que se conhece. Enquanto que aprender somente é possível se houver base anterior para aprender e condições físicas adequadas - ausência de doenças ou limitação fisiológica. Além disso, aprender pode ocorrer mesmo que alguém não ensine explicitamente. As formas de ensino apresentadas pelo autor são:
a) transmitir fatos;
b) cultivar hábitos;
c) treinar habilidades;
d) desenvolver capacidades;
e) despertar interesse e mostrar.

Hirst (1971) defende tese semelhante à de Passmore (1980) quanto à relação triádica. Contudo, caracteriza o ensinar apenas se este for uma atividade intencional, mesmo que o produto final não seja a aprendizagem efetiva.

Pino (2006) argumenta que ensinar pode ser entendido em três direções:
a) como um mero ato de transmissão;
b) como efeito do treinamento;
c) e como um processo de descoberta sob a orientação do outro. 
A primeira forma aponta para a transmissão de um conceito e a simples recepção pelo que aprende, o segundo sentido refere-se a uma aprendizagem que ocorre em um processo de repetição de certos conhecimentos. A terceira visão de ensino pressupõe a atuação na procura ativa de descobrir o conhecimento, por parte de quem aprende.

Pouco antes, Lowyck et al. (2004) propõem uma visão similar à de Pino (2006), na qual existem duas formas para conceber ensinar:

a) didático/reprodutivo: ensinar (atividade do professor) é a transmissão de conhecimento e garante a aprendizagem. Neste modelo, o estudante é passivo no processo.

b) facilitador/transformativo: o professor facilita o processo de aprendizagem do aluno, que é por sua vez autônomo e responsável pelo processo. Neste caso o aluno é ativo e co-responsável pelo processo.

Porlán et al. (1997) destacam alguns possíveis grupos de classificação de aprendizagem e ensino. O primeiro grupo se refere ao ensino de ciências, e possui três categorias:

a) orientação de desenvolvimento conceitual, a qual se foca na interação entre as idéias dos estudantes e explicações dos professores;

b) orientação de compreensão do conteúdo, a qual se refere à aquisição de novas idéias ou substituição das pré-existentes por idéias presentes nas explicações do professor;

c) orientação de aquisição factual refere-se à consideração dos interesses e necessidades dos estudantes, apesar de trabalhar com a aquisição de conceitos, não se foca na discussão e explicação desses. Destaca a importância de se saber fazer ciências e saber sobre ciências. 
Outra classificação de concepções de ensino sintetizada por Porlán et al. (1997) é:

a) ensino como transmissão de conhecimento, estudante recebe o conhecimento que o professor transmite;

b) ensino como conteúdo organizado, ocorre quando a organização é o principal fator para a aprendizagem;

c) ensino como conjunto de atividades manipulativas, o professor organiza as atividades de ensino para os estudantes atribuírem o significado de cada conceito;

d) ensino como ciclo de aprendizagem, ocorre por meio de fases de exploração, explicação e aplicação dos conceitos aprendidos;

e) ensino como mudança conceitual, parte do pressuposto que os estudantes devem compreender que têm concepções prévias e devem substituí-las por científicas;

f) ensino como guia para aprendizagem (que é vista como construção), neste sentido, o professor deve desenvolver atividades que permitam aos estudantes atribuir sentido às idéias que os primeiros querem que sejam aprendidas, além de realizar a conexão entre tais idéias e explicar seu próprio conhecimento.

Porlán et al. (1998) referem-se ainda, ao modelo Didático Pessoal, o qual possui quatro formas de conceber a aprendizagem e o ensino:

a) tradicional: o professor deve ter bom conhecimento do conteúdo, isto basta para um bom ensino, quando ocorre falha no processo, pode ser porque o professor não tem os conhecimentos adequados ou porque os estudantes possuem capacidade intelectual limitada; 
b) tecnológico: o ensino deve ser focado no desenvolvimento de técnicas, prescrevendo regras e procedimentos, que por sua vez garantem o funcionamento do sistema educacional;

c) espontaneísta: coloca o estudante no centro do processo para que este se expresse, participe e aprenda espontaneamente a partir dos seus interesses pessoais;

d) alternativo (outros): outras formas de ensinar ou aprender que não estão completamente consolidadas e não podem ser sintetizadas.

Outra categorização proposta por Porlán et al. (1998) é o modelo Didático da Teoria Subjetiva da Aprendizagem, que possui três formas de conceber a aprendizagem:

a) apropriação formal: valoriza a existência de algo correto que deve ser transmitido (pelo emissor) e recebido perfeitamente (pelo aluno), uma analogia comum para se referir a tal modelo é a "tábula rasa";

b) assimilação: consiste na apropriação dos conhecimentos disponibilizados pelo professor com a devida utilização nas situações adequadas;

c) construção: o aprendiz é ativo no processo de aprendizagem, não apenas um receptor ou assimilador de conhecimento, o desenvolvimento ocorre de forma gradual, tanto para o grupo quanto para o indivíduo. A aprendizagem não é uma estrutura rígida e ocorre de acordo com cada indivíduo e cada grupo.

Após o levantamento de diversas categorizações acerca de ensinar e aprender, Porlán et al. (1998) destacam uma relação de aprendizagem na qual os estudantes são mais passivos, e recebem as informações através das atividades planejadas pelos professores, e em outra os estudantes são sujeitos ativos, compartilhando conhecimento com quem tem a função de ensinar. 
Isto é, na primeira forma de interação, a relação é unidirecional, o conhecimento ou os conceitos saem de uma fonte para um receptor, e na segunda maneira, a relação é bidirecional e os conhecimentos são compartilhados, co-construídos.

Um trabalho que se destaca acerca de concepções ou visões de educação no Brasil é o de Paulo Freire $\left(1987^{25}\right)$. O autor direcionou suas idéias no âmbito do ensino básico, sobretudo de jovens e adultos. Os princípios de sua filosofia foram constituídos em grande parte no período da ditadura militar brasileira. Por este motivo, a questão social, sobretudo a crítica política fica evidente em algumas partes de sua obra. Freire (1987) propõe que a educação deve ser voltada para a autonomia do educando, valorizando uma visão libertadora, a qual se fundamenta na atuação política crítica dos indivíduos na sociedade. Freire (1987) caracteriza, grosso modo, dois tipos de educação:

a) bancária;

b) problematizadora e libertadora.

Segundo Freire (1987) a Educação Bancária é concebida como:

um ato de depositar, de transmitir valores e conhecimentos [...] a) o educador é o que educa; os educandos, os que são educados; b) o educador é o que sabe; os educandos, os que não sabem; c) o educador é o que pensa; os educandos, os pensados; d) o educador é o que diz a palavra; os educandos, os que a escutam docilmente;

e) o educador é o que disciplina; os educandos, os disciplinados; f) o educador é o que opta e prescreve sua opção; os educandos, os que seguem a prescrição;

g) o educador é o que atua; os educandos, os que têm a ilusão de que atuam, na atuação do educador;

h) o educador escolhe o conteúdo programático; os educandos, jamais ouvidos nesta escolha, se acomodam a ele;

i) o educador identifica a autoridade do saber com sua autoridade funcional, que opõe antagonicamente à liberdade dos educandos; estes devem adaptar-se às determinações daquele

j) o educador, finalmente, é o sujeito do processo: os educandos, meros objetos. (p. 59)

\footnotetext{
${ }^{25}$ A primeira edição data de 1970.
} 
A atribuição do nome da categoria bancária deve-se à analogia na qual o processo educacional é visto como uma dinâmica bancária, na qual o professor - detentor do saber - deposita conhecimentos no estudante, tábula rasa. Segundo tal analogia, os estudantes assumem papéis passivos e recebem sem questionar o conhecimento dos professores que são os sujeitos ativos. Portanto, valoriza-se a assimetria na relação, o professor é responsável pela condução do processo sem levar em conta as questões subjetivas e cotidianas dos aprendizes.

A Educação Problematizadora é vista no sentido da consideração do outro na interação educativa, tanto quem aprende quanto quem ensina, o processo deixa de ser passivo por parte do aprendiz, que passa a ter uma função crítica e ativa no processo de educativo. A função da educação passa a ser o educar para a liberdade, na qual se valoriza os valores de cada envolvido no processo educativo, que é realizado de forma dialógica, por isso Freire (1987) utiliza o termo "educador-educando" para se referir à relação pedagógica. Assim,

a educação libertadora, problematizadora, já não pode ser o ato de depositar, ou de narrar, ou de transferir, ou de transmitir "conhecimentos" e valores aos educandos, meros pacientes, à maneira da educação "bancária", mas um ato cognoscente. Como situação gnosiológica, em que o objeto cognoscível, em lugar de ser o término do ato cognoscente de um sujeito, é o mediatizador de sujeitos cognoscentes, educador, de um lado, educandos, de outro, a educação problematizadora coloca, desde logo, a exigência da superação da contradição educador-educandos. (p.68)

Segundo a visão de educação problematizadora, ambos os indivíduos podem aprender no processo educativo. E não somente o educando pode "receber conhecimentos". É mais adequado falar em um processo de compartilhamento de conhecimento, uma vez que os sujeitos aprendem mutuamente uns com os outros.

Nesta seção nos propomos a identificar características comuns que pudessem contribuir para a caracterização das zonas dos perfis conceituais de ensinar e 
aprender. Nos vários levantamentos apresentados até o momento, identificamos duas as categorias de ensinar e aprender que parecem ser mais recorrentes:

a) Os interagentes, quem ensina e quem aprende, nos processos educativos são ativos, e há troca ou construção conjunta de conhecimento.

b) Um interagente no processo educativo, geralmente quem ensina, é ativo e o outro - normalmente o aprendiz - é passivo. Estabelece-se uma relação de transmissão/recepção de conhecimento.

Procurando caracterizar mais adequadamente as zonas dos perfis conceituais de ensinar e aprender, além da discussão acerca das concepções de ensinar/aprender até o momento apresentado, consideramos ser necessário investigar a relação entre quem ensina e quem aprende, desenvolvemos na próxima seção uma breve discussão de alguns trabalhos referentes à temática.

\subsubsection{Algumas visões de interação entre pares}

Uma das perspectivas nas quais nos baseamos para a construção de categorias que permitam relacionar as zonas do perfil conceitual com os contextos de uso, é dos tipos de interação entre pares. Em particular nos apoiamos nas pesquisas que foram desenvolvidas acerca dos estilos parentais (BAUMRIND, 1966, 1997 e 2005). Os estilos, que se referem à como ocorrem as relações entre pais e filhos, são quatro:
a) autoritativo;
b) autoritário;
c) indulgente (ou não-diretivo ou permissivo);
d) negligente. 
No estilo autoritativo os pais "são capazes de estabelecer regras consistentes para o comportamento do filho, além de monitorar sua conduta, corrigir atitudes negativas e encorajar atitudes positivas" (VASCONCELOS \& SOUZA, 2006, p.17). A relação autoritária é baseada na imposição autocrática de limites, regras estritas, sem dialogia com a criança e freqüentemente regida pela punição física dos filhos. Os pais indulgentes procuram suprir todas as demandas dos filhos, sendo demasiadamente tolerantes. A categoria negligente refere-se às relações nas quais os pais interagem à distância fornecendo o estritamente necessário aos filhos.

Os estilos parentais têm sua gênese no âmbito familiar, se restringindo a relações de pais com filhos. Apesar da diferença entre a relação educativa familiar e as relações entre professor e aluno, é possível fazer um paralelo para o uso de tais categorias no sistema escolar.

Ao procurar identificar as diferenças entre as categorias, nos deparamos com a questão da independência do filho. Esta pode ser grande, tanto no estilo negligente, quanto no indulgente, e praticamente ausente no estilo autoritário. No estilo autoritativo há negociação - permitida pelo adulto - sobre o que o filho pode fazer autonomamente. Neste sentido, é possível fazer dois agrupamentos.

O primeiro grupo abrange as relações monológicas, os filhos são os "organizadores" da atividade educativa (indulgente e negligente) ou os pais desconsideram a opinião dos filhos detendo todo o "poder" de organizar a atividade (autoritário). Neste primeiro grupo, os filhos quando têm total independência, pouco se importam com a opinião dos pais, e estes últimos, quando adotam o estilo autoritário, praticamente desconsideram a opinião dos filhos; 
O segundo grupo se refere a um meio termo, os pais não deixam de exercer o papel de adultos e organizadores do processo educativo (autoritativo), mas permitem e mesmo incentivam a participação ativa nas decisões.

Recontextualizando as categorias para o sistema formal de ensino, podemos dizer que, na primeira categoria a relação encontra-se em dos extremos, isto é, o professor pode ser autoritário mantendo o "controle total" da organização da sala ou negligente e permissivo deixando para os alunos toda a responsabilidade do processo (laissez-faire), restringindo papel do professor como simples executor do sistema de ensino. Já no segundo agrupamento, a analogia é a de que o professor, autoritativo, atua dialogando com os estudantes, mas não deixa que estes organizem ou ordenem inteiramente o processo educativo.

Neste sentido, propormos duas categorias de interação entre professor e aluno: uma categoria monológica e outra dialógica. É claro que esta nomenclatura não indica situações binárias, mas um contínuo entre dois extremos. Nesta direção, tomamos a decisão de utilizar, nesta recontextualização para a sala de aula, os termos Dialógico e Autoritário como referência a estes dois grupos de modos de relação.

Mortimer \& Scott (2003), baseados em Lotman (1988), propõem a noção de abordagem comunicativa para representar as formas de interação entre professor e estudantes em sala de aula ${ }^{26}$. Os autores propõem duas dimensões para descrever as interações em sala de aula. A primeira é composta pelas categorias "de autoridade" e “dialógico" e a segunda "interativo" e "não-interativo". Apesar dos termos utilizados para os estilos parentais serem semelhantes às categorias da primeira dimensão da abordagem comunicativa (MORTIMER \& SCOTT, 2003), estas são nitidamente diferentes. A tradução para “authoritative” realizada pelos autores (MORTIMER \& SCOTT, 2002; AGUIAR JR \&

\footnotetext{
${ }^{26}$ Cabe destacar que se referem ao desenrolar da atividade interativa em sala de aula e não à forma de relação contínua entre os indivíduos. Há exemplos no trabalho de mudança de abordagem comunicativa no processo.
} 
MORTIMER, 2005; SCOTT, et al., 2006) é “de autoridade”, e equivale ao autoritário nos estilos parentais. Enquanto que o autoritativo dos estilos parentais é próximo ao dialógico na abordagem comunicativa.

Ao se verificar nos dicionários Cambridge (2008), Longman (2008) e Chambers (2008), o termo "authoritarian" indica uma relação de poder mais intensa e, de algum modo, restringe a liberdade do outro, assim a traduzimos como autoritário. No caso da palavra "authoritative",- o sentido atribuído é a de uma pessoa importante ou que possui saber diferenciado sobre determinado assunto ${ }^{27}$, assim pode-se traduzir como autoritativo ou autoridade, contudo se referem a contextos diferentes. Autoritativo relaciona-se com uma forma de relação e autoridade como conhecimento de uma pessoa sobre certo assunto. Acreditamos que em português os significados mais comuns para autoritativo e autoritário estão mais próximos aos apresentados nos estilos parentais. Cabe destacar que nem todos os dicionários em português definem diretamente o significado de autoritativo, contudo é possível identificar a palavra indiretamente. Um exemplo para a referência indireta é o prefixo “aug” - que se refere a autoria - no dicionário Houaiss (2007).

Pelo levantamento das concepções realizadas nesta seção e dos estilos parentais, identificamos algumas coincidências entre várias das vertentes de concepções de educação, ensino/ensinar e aprendizagem/aprender. As diversas propostas referem-se a metodologias, a objetivos e espaços de ensino/aprendizagem. Contudo, a característica que parece permear a maior parte dos trabalhos refere-se a como os indivíduos envolvidos no processo de ensino-aprendizagem se portam. Identificamos duas concepções básicas neste sentido:

\footnotetext{
${ }^{27}$ Um exemplo de frase nesta direção seria "A autoridade ensinou como resolver os problemas enfrentados".
} 
a) Autoritária: há um transmissor de conhecimento (que pode ser o professor) com papel ativo e um receptor com função passiva de recepção ou depósito de conhecimento.

b) Dialógica: todos os indivíduos são ativos no processo, podendo ambos (aprender com)/(ensinar) o outro, se colocando na posição de mútuo entendimento.

Na concepção autoritária o processo é focado no transmissor, que não leva em conta as características próprias do indivíduo que recebe / aprende. Os aprendizes não questionam os valores ou conceitos transmitidos pelos transmissores, assim é valorizada uma assimetria entre quem detém o conhecimento e que informa e quem não detém o conhecimento, o receptor.

$\mathrm{Na}$ concepção dialógica o processo não tem foco específico já que os indivíduos envolvidos no processo consideram-se mutuamente, levam em conta as necessidades particulares, e ambos compartilham conhecimento, habilidades, conceitos, contextos e significados, e mesmo constroem cada um destes em cooperação. Ambos ensinam e aprendem no processo educativo. Apesar da assimetria do conhecimento estar presente, é minimizada uma vez que as questões individuais e do grupo são valorizadas. Neste sentido, o indivíduo que detém conhecimento diferenciado passa a ser uma referência e não uma fonte de conhecimento. Apresentamos a síntese das categorias propostas após esse levantamento na Tabela 2.

Tabela 2: Síntese das categorias de Concepções de Aprendizagem/Aprender e Ensino/Ensinar

\begin{tabular}{c|c|c|c|c}
\hline \hline Categoria & Característica & Quem ensina & Aprendiz & Ensinar-aprender \\
\hline \hline \multirow{2}{*}{ Autoritária } & Ação & $\begin{array}{c}\text { Transmite } \\
\text { conhecimento } \\
\text { ativamente }\end{array}$ & $\begin{array}{c}\text { Recebe } \\
\text { conhecimento } \\
\text { passivamente }\end{array}$ & $\begin{array}{c}\text { Processo unidirecional } \\
\text { de transmissão } / \\
\text { recepção de } \\
\text { conhecimento }\end{array}$ \\
\cline { 2 - 5 } & Relação & Ativa e Autoritária & Passiva e não-crítica & $\begin{array}{c}\text { Caracterizado pela } \\
\text { ausência de diálogo }\end{array}$ \\
\hline
\end{tabular}




\begin{tabular}{c|c|c|c|c}
\hline \hline Categoria & Característica & Quem ensina & Aprendiz & Ensinar-aprender \\
\hline \hline Dialógica & Ação & $\begin{array}{c}\text { Aprende/ensina, } \\
\text { compartilha } \\
\text { conhecimento, } \\
\text { habilidades, } \\
\text { conceitos, contextos } \\
\text { e significados } \\
\text { posição crítica. }\end{array}$ & $\begin{array}{c}\text { Aprende/ensina, } \\
\text { compartilha } \\
\text { conhecimento, } \\
\text { habilidades, } \\
\text { conceitos, contextos } \\
\text { e significados } \\
\text { posição crítica. }\end{array}$ & $\begin{array}{c}\text { Visto como o } \\
\text { compartilhamento e } \\
\text { co-construção de } \\
\text { conceitos, contextos, } \\
\text { significados e } \\
\text { conhecimento. }\end{array}$ \\
\cline { 2 - 6 } & Relação & $\begin{array}{c}\text { Ativa e Dialógica } \\
\text { Ativa e Dialógica }\end{array}$ & $\begin{array}{c}\text { Caracterizado pela de } \\
\text { diálogo e } \\
\text { consideração do outro }\end{array}$ \\
\hline \hline
\end{tabular}

Apesar de identificarmos estes dois extremos, é esperado que por vezes as concepções se misturem e sejam de difícil diferenciação, assim propomos uma terceira categoria Amalgamada/Duvidosa, a qual compreende características das duas outras categorias.

\subsection{Tipo}

Nesta seção, discutiremos a dimensão chamada Tipo, que faz parte da estrutura de categorias do questionário. Esta dimensão está baseada nas Teorias de Desenvolvimento e Aprendizagem da psicologia.

Cabe destacar que existem várias classificações possíveis das teorias de desenvolvimento e aprendizagem. Isso se deve ao fato de que algumas teorias comungam de pontos de concordância. Diversos trabalhos (e.g. MOREIRA, 1999) consideram três conjuntos de teorias: humanistas, cognitivistas e behavioristas. Neste trabalho decidimos utilizar uma classificação similar a utilizada por Coutinho e Moreira (1992). Estes autores classificam as teorias como: maturacionais; comportamentalistas; de campo; fenomenológicas; e psicogenéticas. 
a) Teorias Maturacionalistas

As teorias maturacionais têm como eixo comum a consideração de que, em qualquer organismo vivo, o desenvolvimento do comportamento é geneticamente programado. Neste sentido, apesar do ambiente ou fatores externos poderem influenciar no desenvolvimento, só o fazem a partir da programação genética. Stanley Hall, um dos teóricos maturacionais, afirmava que o desenvolvimento ontogenético ocorre a partir das mesmas fases do desenvolvimento filogenético da espécie (COUTINHO \& MOREIRA, 2001, p.25). Tal linha valoriza o conhecimento inato ou programado biologicamente.

b) Teorias Comportamentalistas (ou Behavioristas)

As teorias comportamentalistas apóiam-se na idéia que o conhecimento é constituído a partir da experiência e não é inato. Assim, a psicologia deve estudar o comportamento dos indivíduos por meio das suas reações observáveis em respostas a estímulos proporcionados pelo ambiente (DAVIS \& OLIVEIRA, 1994; COUTINHO \& MOREIRA, 2001). O comportamento humano passa a ser entendido como atividades dependentes de estímulos ambientais, ou seja, como respostas aos estímulos. Assim, o comportamento pode ser previsto se identificadas as relações entre os estímulos do meio e as respostas comportamentais dadas (DAVIS \& OLIVEIRA, 1994; COUTINHO \& MOREIRA, 2001). Os estímulos ambientais são responsáveis pelo reforço - positivo ou negativo - do comportamento do indivíduo. Quando o indivíduo recebe um reforço positivo, tente a repetir o comportamento e quando recebe reforço negativo enfraquece certo comportamento (LOMÔNACO, 1975; DAVIS \& OLIVEIRA, 1994). “A aprendizagem, na visão ambientalista, pode ser entendida como o processo pelo qual o comportamento é modificado como resultado da experiência." (DAVIS \& OLIVEIRA, 1994, p.33). 


\section{c) Teorias de Campo}

As teorias de campo se baseiam na idéia de que as experiências humanas não são fracionáveis, isto é, "o todo" não é somente a soma das partes (COUTINHO \& MOREIRA, 2001) e têm como principal referencial teórico a Psicologia da Gestalt (ou da Forma). Para os seguidores da Gestalt, é possível estabelecer organizações inatas préformadas comuns a todos os indivíduos que definem os campos perceptivos destes. Essas estruturas determinam e condicionam as experiências perceptuais, também chamadas de gestaltens dos indivíduos. As gestaltens são consideradas as estruturas mentais geradoras do conhecimento e proporcionam a interpretação dos estímulos - que deixam de ser puros (COUTINHO \& MOREIRA, 2001). Na teoria da Gestalt, existe uma tendência humana de procurar a "boa forma", que gera todo o processo perceptivo. Os estímulos são interpretados a partir do contexto em que são inseridos, por exemplo, uma figura pode ser percebida diferentemente dependendo das figuras ou do fundo no qual é colocada. A aprendizagem se refere à reação, em situações significativas, na qual o indivíduo reorganiza repentina e totalmente seu campo perceptual, isto é, tem insights. Logo, a aprendizagem é vista na direção de reestruturação da cadeia cognitiva a partir das relações da situação ou do estímulo no contexto. Quanto ao processo educativo, o professor é visto como facilitador da aprendizagem que será efetivamente realizada pelo aluno.

d) Teorias Fenomenológicas e Humanistas

As teorias humanistas surgem como alternativa ao Behaviorismo e às Teorias Maturacionais. Por meio da percepção da realidade, o sujeito pode evoluir seus valores para chegar à realização pessoal (COUTINHO \& MOREIRA, 2001). Um dos principais autores da linha humanista é Carl Rogers, que considerava a educação como um processo a ser desencadeado pelo aprendiz - de acordo com seus próprios objetivos e motivações - para culminar em uma aprendizagem significativa. Isto é, não limitada à 
acumulação de conhecimento, levando à reorganização das emoções, cognição, valores e atitudes do sujeito (COUTINHO \& MOREIRA, 2001). Portanto, o professor assume o papel de facilitador que auxilia o aluno, que é livre para conduzir seu próprio o processo de aprendizagem.

\section{e) Teorias Psicogenéticas}

As duas correntes psicogenéticas mais difundidas são representadas pelos seguintes autores:

\section{i) Piaget}

ii) Soviética: Vigotski, Luria, Leontiev.

Apesar de considerar a divisão em apenas duas linhas, é possível identificar aspectos comuns nos dois grupos. Além de existir a semelhança existem outros pesquisadores não citados. Contudo, optamos pelos autores psicogenéticos que consideramos ter o maior impacto na psicologia do desenvolvimento e da aprendizagem ainda hoje. A complexidade de se caracterizar estes grupos é motivo de ampla discussão. Mesmo a interpretação de um mesmo autor pode ser bastante controversa, como por exemplo, as diversas interpretações do conceito de Zona de Desenvolvimento Proximal, discutidas por Moore (2004). Neste sentido, apresentamos alguns pontos comuns e divergentes entre os estes grupos.

As duas correntes se relacionam o comportamento humano e interação de sujeitos e objetos que levam à reestruturação das estruturas cognitivas dos indivíduos, modificando os sujeitos. Para Piaget, o desenvolvimento dos indivíduos ocorre em fases universais e biologicamente programadas, contudo individualmente atingidas. Para Vigotski e outros pesquisadores do segundo grupo, o desenvolvimento, apesar com influência biológica, ocorre principalmente de acordo com as interações sociais nas quais os indivíduos se envolvem. Para ambos os grupos a interação com o mundo é importante para o 
desenvolvimento do psiquismo humano, além disto, para o segundo grupo, a linguagem passa a ter o status de orientadora do comportamento do sujeito, sendo pensamento e linguagem intimamente interligados e existentes desde o início da vida

Como discutimos brevemente na seção anterior, as visões de ensinar e aprender da dimensão concepções de educação são, por vezes, influenciadas pelas correntes da Psicologia da Educação. Portanto, as categorias apresentadas nesta seção influenciam a constituição das zonas de perfil conceitual, e também por se referirem a vários processos e conceitos relacionados à aprendizagem e ao ensino.

Esta seção é sintetizada na dimensão Tipo do esquema representado na Figura 3.

\subsection{Onde}

A aprendizagem e o ensino intencional é uma das características que diferenciam o homem de outros animais (VYGOTSKY \& LURIA, 1996). Nem sempre existiu um ambiente com finalidade única de ensinar e a educação é por vezes baseada na educação familiar ou religiosa. Mesmo na sociedade contemporânea, a família tem papel importante no ensino nos primeiros anos de vida e mesmo quando a criança já se encontra mais desenvolvida.

Neste sentido, existe uma educação formal - ou escolar - que ocorre em ambientes que tenham como o principal objetivo ensinar. Da mesma forma existe uma educação não-formal - fora da escola - com diversos objetivos e modos de se dar.

Atualmente muito se argumenta sobre o papel de alguns ambientes que não têm como principal objetivo o ensino, como é o caso dos museus na aprendizagem de conhecimentos científicos (MARANDINO, 2004). Em tais locais se podem encontrar 
atividades destinadas ao ensino de algum conhecimento, entretanto as atividades não são o foco de atuação do espaço. A divulgação científica realizada pelos meios de comunicação também não tem como objetivo o ensino de conteúdo, mas pode ser utilizado para o desenvolvimento de atividades educativas (RIBEIRO, 2007).

Segundo Bianconi e Caruso (2005) e Gadotti (2005), existem três tipos de educação: formal, não-formal e informal. A educação formal ocorre em instituições próprias, com cronogramas e hierarquias estabelecidas. Enquanto que a educação informal ocorre em locais externos à escola (BIANCONI \& CARUSO, 2005), como por exemplo, casa, trabalho, campo de futebol etc. A educação não-formal ocorre quando se sistematiza e organiza uma prática educativa externa às instituições do sistema ensino formal (GADOTTI, 2005; BIANCONI \& CARUSO, 2005). Neste sentido, podemos diferenciar a educação informal da não-formal pelo fato de existirem objetivos mais claros nesta última modalidade.

Contudo, devido à ampla abrangência de conhecimentos que podem estar no foco dos objetivos de cada um desses tipos de educação, consideramos adequado assumir uma educação formal e uma não-formal/informal. Isto porque, no espaço não-formal, apesar da sistematização e da organização, os objetivos podem ser semelhantes aos de ambientes informais.

Um exemplo de aprendizagem não-formal é a presença de cursos em ambientes de trabalho com fim de aperfeiçoamento profissional. Alguns desses cursos são organizados e sistematizados, outros são realizados de forma mais informal, não possuindo organização e hierarquias tão explícitas e específicas.

Para definirmos um espaço formal ou não-formal de ensino, muitos fatores devem ser considerados, tanto pela sobreposição dos espaços, tanto pela complexidade do problema em questão. Porém decidimos separar o local (Onde) se aprender/ensina em duas categorias formal/não-formal. Apesar da simplificação, consideramos a possibilidade de 
ocorrer sobreposição de contextos formais e não-formais ${ }^{28}$. Assim, frente ao objetivo de fundamentar as categorias, tomamos como elemento fundamental da diferença entre elas é o ambiente escolar, ou seja, o espaço escolar e o espaço não-escolar.

Assim, utilizaremos o termo espaço de educação formal, referindo-nos a todo processo educacional regular ocorrido em instituição de ensino, com hierarquia de funções dos indivíduos devidamente estabelecida e que tenha como principal objetivo o ensino e a aprendizagem de determinados conhecimentos.

E como espaço de educação não-formal os processos externos às instituições de ensino formal. Apesar do ambiente formal teoricamente remeter à educação formal, este pode ser um misto de contextos formais e informais, uma vez que os indivíduos levam para o espaço formal questões pessoais externas a este. Neste sentido, é necessário se pensar em uma predominância de relações, e que em um espaço formal as relações formais predominam.

\subsection{Quem}

O ensino e a aprendizagem, como discutidos na seção precedente, podem ocorrer fora do ambiente educacional. Na escola, os estudantes podem aprender com o professor ou com um colega ou com um determinado artefato cultural. Contudo, o estudante ou qualquer indivíduo, também, pode aprender com/ensinar outros indivíduos, que não o professor/aluno.

Além de aprender com os professores, os indivíduos podem aprender, independentemente dos espaços em que se encontram, com artefatos ou ferramentas culturais (e.g. televisão, internet, rádio) que foram constituídos socialmente, mesmo que

\footnotetext{
${ }^{28}$ Como discutido na Seção 1.3.3.
} 
esses não tenham intuito primordial de ensinar ou promover a aprendizagem. Como por exemplo, um indivíduo pode aprender conceitos cotidianos e mesmo científicos com um jornal - que tem objetivo informativo e não-didático -, portanto, exercendo de alguma forma o ensino. Mesmo que não estejam claros à primeira vista, os objetos ou artefatos possuem arcabouços culturais intrínsecos que serão compartilhados com aquele que aprende, baseado nos valores culturais e dos conhecimentos que lhe são atribuídos. A enxada, por exemplo, pode ter construída originalmente em uma cultura para facilitar nas tarefas agrícolas, e ao mesmo tempo, pode ser utilizada nesta cultura e em outras para outros meios, como por exemplo, arma de defesa.

Portanto, há várias pessoas e artefatos que podem ensinar/aprender. As categorias desta seção são representadas sinteticamente na dimensão Onde do esquema representado pela Figura 3.

\subsection{Supervisão}

Na seção anterior discutimos Quem? se envolve nos processos de ensino e aprendizagem. Anteriormente discutimos na dimensão Concepções de Educação a respeito da relação estabelecida entre os interagentes processos de ensino-aprendizagem. Contudo, há algumas características relacionados às dimensões citadas que podem identificadas e podem contribuir para a constituição das zonas de perfil conceitual e os contextos de uso destas. A dimensão que contem tais categorias chamamos de Supervisão.

Esta dimensão parte do conceito básico do conceito de Zona de Desenvolvimento Proximal (VIGOTSKII, 1988; VIGOTSKI, 2000 e 2001) discutido na Seção 1.3.5 pressupõe a existência de um parceiro mais capaz ou apto a realizar certa atividade ou resolver uma gama de problemas semelhantes e um parceiro que ainda não consegue. Neste sentido, o sujeito menos apto estabelece uma relação com o parceiro mais 
capaz, na qual os indivíduos conseguem resolver problemas que não conseguiam resolver sozinhos, e que podem, após a interação com o parceiro mais capaz resolver individualmente.

Neste sentido, se um dos sujeitos participantes da interação educacional é visto como o parceiro responsável pelo processo de ensino-aprendizagem, chamamos o processo de supervisionado, caso exista esta figura, tomamos como um processo nãosupervisionado. Uma atividade na qual o professor fica à margem, sem interferir no processo, e que não tenha um estudante responsável por conduzir a atividade é considerado um processo não-supervisionado. Um exemplo de processo supervisionado é a realização de uma atividade direcionada pelos pais. Representamos esquematicamente na Tabela 3 as categorias supervisionado e não-supervisionado.

Tabela 3: Síntese da dimensão situação

\begin{tabular}{lc}
\hline \hline \multicolumn{2}{c}{ Situação } \\
\hline \hline Supervisionada & Não-supervisionada \\
\hline \hline
\end{tabular}

\subsection{O quê?}

Ensinar e aprender, independentemente de como ocorre, de quem está envolvido se refere a certo conhecimento. Neste sentido, ensinar e aprender pode ser abstrato, e se referir a vários conhecimentos sem uma limitação específica. Ou pode ser modulado pelos conteúdos específicos, que exigem metodologias específicas e partem de pressupostos diferentes. Neste sentido, cada área do conhecimento é construída historicamente de forma diferentes, necessitando abordagens distintas. Por exemplo, ensinar/aprender Educação Física pode ser substancialmente diferente de ensinar/aprender Matemática.

Neste sentido, neste trabalho focamos a Física como conteúdo específico por meio dimensão $O$ quê?. Isto por que, estamos interessados na formação de professores de Física e Ciências, que por certo difere da formação de professores de outras áreas. 


\subsection{Por quê / Para quê?}

Além do conteúdo a ser ensinado/aprendido, é necessário que se reflita sobre os motivos e as utilidades do conteúdo. Por que e Para que ensinar/aprender. Neste sentido, contemplando os valores e a dimensão axiológica dos perfis conceituais, propomos a dimensão Por quê / Para quê. Tal dimensão refere-se às questões sociais e culturais que estão por trás de ensinar e aprender conteúdos escolares e não-escolares. Diferentes culturas podem considerar mais ou menos importantes certos conhecimentos que outras. A dimensão pode auxiliar na tentativa de investigar o que leva os indivíduos a optar por ensinar e aprender ou não um conhecimento.

Esta categoria foca-se na dimensão axiológica do perfil conceitual, uma vez que se refere aos motivos e aos fins da educação, bem como as questões mais subjetivas dos indivíduos ou dos grupos.

\subsection{Considerações}

Nas seções precedentes deste capítulo, discutimos várias visões, categorias e dimensões relacionadas aos perfis conceituais de ensinar e aprender. Procuramos destacar ao final de cada seção as categorias a serem utilizadas neste trabalho. Contudo, sabemos que há outras sínteses possíveis. Percebemos que a divisão em diversas dimensões serve para reduzir a complexidade de análise dos perfis conceituais, que sem dúvida possui muitas outras dimensões relacionadas. Em alguns casos, como por exemplo, as concepções de educação e supervisão, há sobreposições das categorias. Esta também está relacionada à complexidade do perfil conceitual, ou dos perfis conceituais envolvidos, que por vezes possuem certas regiões ou subsistemas menos complexos com várias ligações hierárquicas. Contudo, é necessário conseguirmos estabelecer critérios de análise dos perfis, para tanto, 
optamos por realizar uma representação esquemática bidimensional (Figura 3) das categorias relacionadas aos perfis conceituais de ensinar e aprender. Estas podem ser relacionadas à constituição das zonas de perfil ou ao estabelecimento de contextos de uso destas.

No sentido de representar os perfis conceituais complexo, podemos definir hierarquias entre as dimensões e categorias, e assumir que a representação esquemática, grosso modo, é uma representação dos perfis de ensinar e aprender. É possível as ligações entre as categorias e dimensões origina-se da complexidade dos contextos e das zonas de perfil conceitual, e será mais profundamente trabalhada quando construirmos as perguntas a serem utilizadas no questionário.

Julgamos que o esquema (Figura 3) - em apenas duas dimensões - que representa as dimensões e categorias em hierarquias e mesmo distingue estas, é apenas uma opção metodológica e prática para delimitação do objeto de pesquisa. O recorte estabelecido, - hierarquias, dimensões e categorias sugeridas - serve como ponto de partida para uma representação dos conceitos complexos envolvidos nesta pesquisa, bem como auxilia na análise da relação entre tais conceitos.

A representação esquemática parte da Pergunta de Trabalho 2, referente à existência de um conceito mais complexo que engloba os conceitos de ensinar e aprender. Partimos de uma hierarquia de representação menos complexa na qual tratamos separadamente os conceitos de ensinar e de aprender. Cremos que perguntas realizadas nestas categorias levem ao estabelecimento de contextos mais genéricos. Assim começamos com a categoria $O$ que é [ensinar/aprender]?. Essa pergunta configura o que chamamos de hierarquia de primeira ordem. As categorias subjacentes estão em hierarquias inferiores, as quais chamamos de hierarquia de segunda, terceira e quarta ordens. Às ordens, associamos uma ordinalidade, que se refere à generalidade do contexto associado, assim, quanto mais abaixo no esquema, mais definido é o contexto a que se refere a pergunta. 


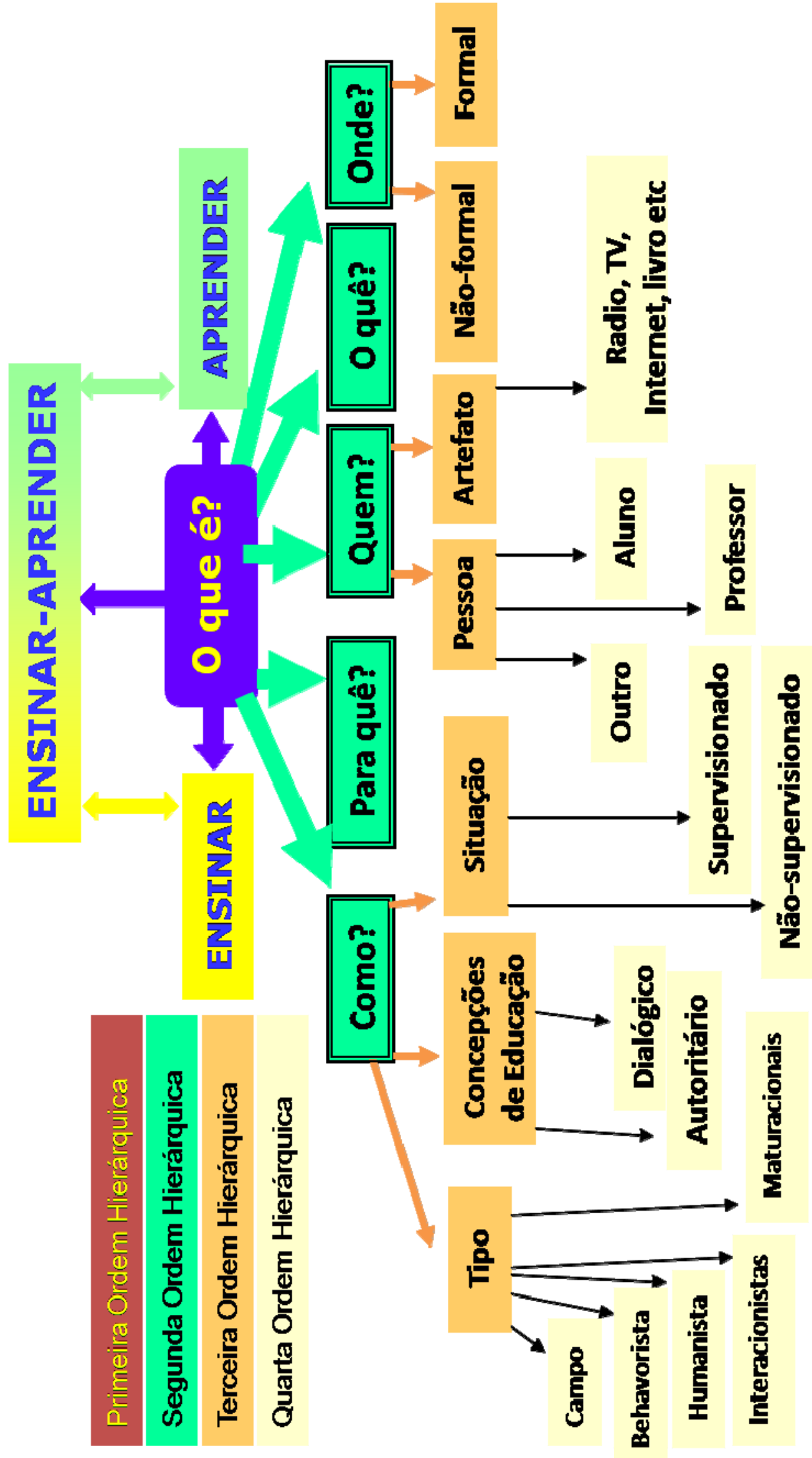

Figura 3: Esquema com as categorias utilizadas para construção das questões do questionário 
$\mathrm{Na}$ hierarquia de segunda ordem temos a questão Para quê [ensinar/aprender]?. Esta pergunta está relacionada com a dimensão axiológica do perfil conceitual, ou seja, com os valores e fins atribuídos aos dois conceitos. Essa dimensão, que será tratada em trabalho futuro, vem sendo fundamentada no trabalho de Mattos e colaboradores (2008).

Ainda na hierarquia de segunda ordem temos a questão $\underline{O} q u \hat{e}$ [ensinar/aprender]?. Essa questão se relaciona com o conteúdo específico que se ensina e se aprende. Neste trabalho tratamos o ensinar e aprender física.

Na hierarquia de segunda ordem, a questão “Quem [ensina/aprende]?” se refere, em níveis hierarquicamente inferiores (terceira ordem), as categorias Pessoa, Artefato e Outro, no que se refere com Quem?/O que [ensina/aprende]. Sob essas categorias são elencados elementos que se referem a contextos ainda mais específicos (quarta ordem) como, por exemplo, as pessoas que ensinam ou aprendem o fazer com pais ou filhos, professores ou colegas ou os artefatos (e.g. livro, televisão ou rádio).

Outra questão de segunda hierarquia é Onde [ensinar/aprender]?, a qual se refere aos lugares nos quais ensinar e aprender ocorrem. Em nível hierárquico de terceira ordem temos os espaços de ensino/aprendizagem Formal e Não-formal.

A última questão de segunda ordem Como [ensinar/aprender]?, refere-se às formas como ocorrem as interações de ensino e aprendizado. Neste nível hierárquico estão associados dois níveis de terceira ordem: Concepções de Educação, Situação e Tipo (de ensino e/ou aprendizagem).

A categoria Concepções de Educação se refere a um quarto nível hierárquico que inclui as categorias de quarta ordem Autoritária e Dialógica. A categoria Situação refere-se a hierarquia de quarta ordem com duas categorias relativas às ações de ensinar/aprender Supervisionada e Não-supervisionada. Essas categorias pretendem 
representar a existência ou não de outros como responsáveis pelo processo de ensino e/ou aprendizagem, seja ele professor/aluno, adulto/criança. A dimensão Tipo se refere a elementos relacionados às formas com o outro é compreendido. A esta categoria de terceira ordem estão associadas outras categorias de quarta ordem (Maturacionais, Comportamentalistas, de Campo, Fenomenológicas ou Humanistas e Psicogenéticas), as quais foram inspiradas nas correntes da psicologia do desenvolvimento e aprendizagem.

A construção da representação esquemática teve por objetivo facilitar a construção do questionário para levantamento dos perfis conceituais que será realizada no próximo capítulo. 
CAPÍTULO 4:

\section{O QUESTIONÁRIO}


Até o momento apresentamos o referencial teórico, o problema de pesquisa, além de discutir as categorias . Apesar de ter discutido os dados do questionário piloto, somente com o questionário final é possível analisar a possibilidade de se construir um questionário com a finalidade de medição de perfis conceituais em contextos específicos. As categorias discutidas no CAPÍTULO 3: e representadas pela Figura 3 assumem corpo no presente capítulo. O questionário está constituído por duas partes básicas: informações pessoais e questões relacionadas a ensinar e a aprender. Num primeiro momento deste capítulo, apresentaremos pontos relacionados à construção do questionário e sobre a caracterização da amostra - realizada com base na primeira parte do questionário. Num segundo momento, discutiremos as relações entre questões, respostas, ensinar, aprender e contextos com base nas categorias prévias representadas esquematicamente na Figura 3.

\subsection{A construção}

As questões do questionário foram construídas com base no esquema da Figura 4 e aos pares, isto é, cada par de questões é composta por uma questão que se referir a ensinar e outra a aprender como, por exemplo: “O que é aprender?” e “O que é ensinar?”.

No total foram criadas 45 questões, 23 para aprender e 22 para ensinar. A questão em “Como se aprende sem a ajuda de outra pessoa?" não teve par, pois julgamos que é muito provável que a amostra respondesse, em sua maioria, a possibilidade de se ensinar sem a ajuda de outra pessoa. Entre outras, essa foi uma das questões que foram retiradas do questionário a partir da análise do questionário piloto para que este pudesse ter um número menor de questões. 
Para validar as questões construímos quatro modelos de questionários. Cada um deles era composto por questões que foram agrupadas para permitir que independente de cada um dos modelos de questionário pudéssemos ter respostas que caracterizassem, da mesma maneira, os perfis conceituais. Cada questionário contava com cerca da metade do total de questões. Representamos esquematicamente na Figura 4 a distribuição das questões por questionário.

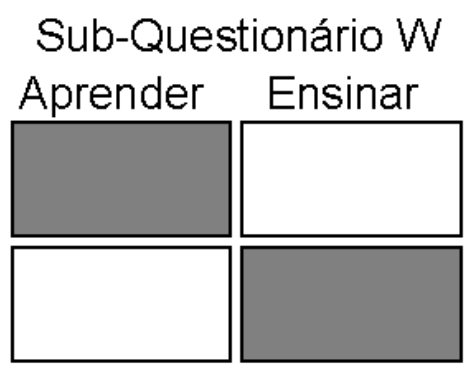

Sub-Questionário $Y$
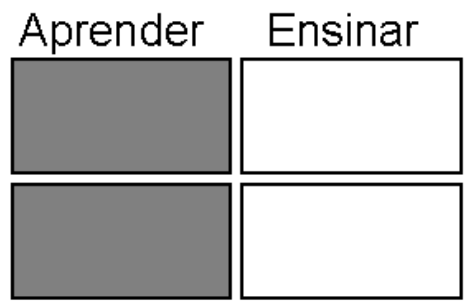

Sub-Questionário X Aprender Ensinar

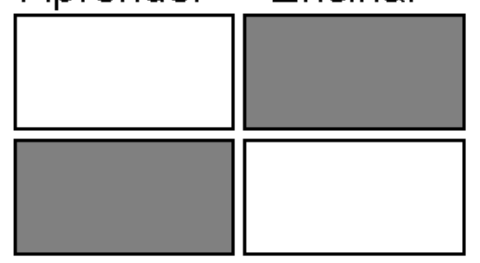

Sub-Questionário Z

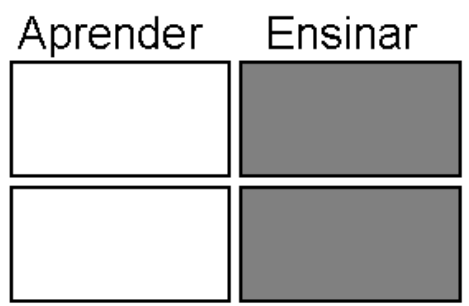

Figura 4: Distribuição das questões nos questionários. Na coluna “Aprender” estão as questões sobre aprender e na coluna "Ensinar" as questões sobre ensinar. As cores representam as duas metades das questões relacionadas à aprender $\mathbf{e}$ à ensinar.

A vantagem de se distribuir as questões por modelos de questionários é que o número de questões por questionário fica menor, aumentando a chance de que os estudantes respondessem-nos completamente. Outra vantagem é que reduzimos a quantidade de dados a serem categorizados e posteriormente analisados. Além disso, se verificada a equivalência entre os questionários é possível utilizá-los em momentos distintos para identificar uma possível evolução do perfil conceitual ao longo do tempo.

A desvantagem é que nem todas as repostas podem ser comparadas para um mesmo sujeito, i.e., não podemos comparar certos pares de questões, ou mesmo todas as 
questões relativas a aprender com outras relativas a aprender, o mesmo pode ser dito das questões relativas a ensinar. Outra redução, com a fragmentação do questionário, é a do tamanho da amostra em cada modelo de questionário, pois um número menor de estudantes as responderá.

Portanto ganhamos na redução de dados e na simplificação da análise dos perfis conceituais do grupo e perdemos no volume de dados sobre os perfis conceituais dos individuais. Julgamos que os pontos positivos prevalecem sobre os negativos, sobretudo por assumirmos o foco como a análise de uma disciplina do curso de formação de professores de Física como um todo e não apenas como indivíduos isolados. Ao partirmos do pressuposto teórico que os sujeitos individuais são parte de um contínuo coletivo, no qual tanto indivíduo quanto cultura são constituídos dialeticamente, privilegiar o perfil conceitual coletivo apenas minimiza cada um dos indivíduos. Contudo, o retrato individual acaba sendo contemplado, pois o perfil conceitual coletivo também é constituído dialeticamente com os indivíduos.

Quanto à criação das questões, construímos com base no esquema apresentado na Figura 3. Dentro das diversas possibilidades proporcionadas pelas categorias prévias, optamos por algumas relações entre as dimensões que julgávamos mais relevantes. Isso porque seria necessária uma infinidade de perguntas para se realizar todas as possibilidades de contexto. Portanto, inviabilizaria aos estudantes responderem em tempo razoável, além do volume de dados pressupor um tempo de análise que suplantaria o tempo disponível para análise de dados no cronograma do projeto de mestrado. Assim, optamos por fazer esse recorte..

O questionário foi construído com questões compostas a partir de categorias de diferentes níveis hierárquicos, o que significa diferentes graus de contextualização. Algumas perguntas foram formuladas a partir de uma das dimensões de segunda ordem. Um exemplo é a pergunta "Como se aprende?", que possui a palavra como, referente à dimensão como e a 
expressão aprende referente à aprender. Já a questão "Em quais locais não é possível ensinar?, refere-se à dimensão Onde e à dimensão Aprender, levando a contextos menos delimitados.

Outras questões foram cunhadas a partir da utilização simultânea de duas ou mais categorias. Um exemplo é a questão "Fora da escola onde um professor ensina?", esta pergunta refere-se à dimensão Quem (categoria Professor), à dimensão Formal.

Outras, ainda, foram formuladas com categorias de hierarquia menos gerais, ou seja, de terceira ou quarta.Um exemplo para este tipo de pergunta é "De que forma se colocar na posição do outro ajuda a aprender? , que foi construída na categoria Dialógica da Dimensão Concepções de Educação.

Nessas questões, a delimitação do contexto depende de quantas categorias de hierarquias inferiores existem abaixo da categoria onde foi criada a questão. Quanto mais a baixa a hierarquia mais específico o contexto da questão, mais são os elementos discursivos disponíveis para o reconhecimento do contexto, estreitando o número de contextos possíveis de serem reconhecidos.

Com a especificação intencional de contextos esperamos, mais que identificar as zonas, identificar como ocorre sua utilização em contextos. Ao utilizar certas categorias na formulação de uma questão, estamos privilegiando o uso de certas zonas, as quais os indivíduos acham mais adequadas aos contextos que propomos.

As questões tinham uma ou duas categorias principais, e por vezes outras secundárias, a serem consideradas posteriormente. Na Tabela 4, apresentamos as perguntas do questionário. 
Tabela 4: Questões e categorias do questionário

\begin{tabular}{|c|c|}
\hline Sigla & Questão \\
\hline Q01A & O que é aprender? \\
\hline Q01E & O que é ensinar? \\
\hline $\bar{Q} 02 \mathrm{~A}$ & Em quais locais não é possível aprender? \\
\hline$\overline{\mathrm{Q} 02 \mathrm{E}}$ & Em quais locais não é possível ensinar? \\
\hline Q03A & Como se aprende? \\
\hline$\overline{Q 03 E}$ & Como se ensina? \\
\hline Q04A & Como se aprende fora da escola? \\
\hline Q04E & Como se ensina fora da escola? \\
\hline Q05A & Como se aprende na escola? \\
\hline Q05E & Como se ensina na escola? \\
\hline Q06A & Como se aprende sem a ajuda de outra pessoa? \\
\hline$\overline{Q 07 A}$ & De quais formas podemos aprender com um colega na escola? \\
\hline$\overline{Q \text { Q07E }}$ & De quais formas podemos ensinar um colega na escola? \\
\hline $\mathrm{Q08A}$ & $\begin{array}{l}\text { Muitas vezes o adulto fala à criança: "Tira o dedo da tomada" De quais } \\
\text { formas é possível um aluno aprender desta forma? }\end{array}$ \\
\hline Q08E & $\begin{array}{l}\text { Muitas vezes o adulto fala à criança: "Tira o dedo da tomada!" De quais } \\
\text { formas é possível um professor ensinar desta forma? }\end{array}$ \\
\hline Q09A & De que forma se colocar na posição do outro ajuda a aprender? \\
\hline Q09E & De que forma se colocar na posição do outro ajuda a ensinar? \\
\hline$\overline{Q 10 A}$ & Como um professor pode aprender com um aluno? \\
\hline$\overline{Q 10 E}$ & Como um aluno pode ensinar um professor? \\
\hline Q11A & Como se aprende com a televisão na escola? \\
\hline Q11E & Como se ensina com a televisão em casa? \\
\hline Q12A & Como se aprende com o livro em casa? \\
\hline$\overline{Q 12 E}$ & Como se ensina com o livro na escola? \\
\hline Q13A & Fora da escola onde um aluno aprende? \\
\hline Q13E & Fora da escola onde um professor ensina? \\
\hline Q14A & Como se aprende a jogar futebol? \\
\hline Q14E & Como se ensina a jogar futebol? \\
\hline$\overline{Q 15 A}$ & Como o Ronaldinho aprendeu a jogar bola? \\
\hline$\overline{Q \text { Q15E }}$ & Quem ensinou o Ronaldinho a jogar futebol? \\
\hline Q16A & O que é aprender física? \\
\hline Q16E & O que é ensinar física? \\
\hline Q17A & Como se aprende física? \\
\hline Q17E & Como se ensina física? \\
\hline Q18A & Como se aprende física bem? \\
\hline Q18E & Como se ensina física bem? \\
\hline Q19A & Como se aprende física mal? \\
\hline Q19E & Como se ensina física mal? \\
\hline Q20A & Onde se aprende física bem? \\
\hline
\end{tabular}




\begin{tabular}{ll}
\hline \multicolumn{1}{c}{ Sigla } & \multicolumn{1}{c}{ Questão } \\
\hline \hline Q20E & Onde se ensina física bem? \\
\hline Q21A & Como se aprende em um convento? \\
\hline Q21E & Como se ensina em um convento? \\
\hline Q22A & O que é aprender física mal? \\
\hline Q22E & O que é ensinar física mal? \\
\hline Q23A & Como um bebê aprende a mamar? \\
\hline Q23E & Como se ensina um bebê a mamar? \\
\hline \hline
\end{tabular}

Para se evitar respostas evasivas ou que gerem dúvida ou que sejam fornecidas de forma automática, quando se constroem questões, utilizam-se questões inversas ou na negativa (BABBIE, 2003). Por exemplo, na grande maioria das vezes no questionário piloto, a resposta para a questão “Em quais locais é possível aprender/ensinar?” foi “qualquer”. Essa resposta pode caracterizar uma resposta evasiva ou referir-se a qualquer ambiente, levando à dúvida de entendimento. Por este motivo, no questionário final, a questão foi realizada na negativa foi “Em quais locais não é possível aprender/ensinar?”.Realizando a questão na negativa, partimos do pressuposto que é possível ensinar em qualquer lugar - como verificamos no questionário piloto - e procuramos especificar as exceções. Portanto, pudemos identificar elementos mais relevantes para a pesquisa ao solicitar que o respondente identificasse locais nos quais a ensinar e aprender são dificultados ou inviabilizados.

\subsubsection{Tabulação e Categorização dos Dados}

A análise dos dados do questionário foi qualitativa. Da mesma forma que no questionário piloto, as respostas dadas às questões foram categorizadas utilizando-se as categorias de hierarquia inferior à hierarquia na qual foi construída. Para tanto, identificamos palavras ou expressões que eram características de cada uma das categorias prévias. Cada resposta foi categorizada de acordo com o aparecimento de expressões-chave que caracterizam 
cada categoria. Em alguns casos, um verbo é suficiente para a categorização, pois determina o sentido da frase. Em outras respostas foi necessário observar a resposta como um todo. Aqui, a categorização é a principal forma de obtenção de dados, assim, a validação das categorias realizadas na fase de análise do questionário piloto foi fundamental, pois serviu para estabelecermos as expressões-chave a serem utilizadas no questionário.

Neste trabalho a Categoria A foi utilizada para designar Categoria Autoritária; a Categoria D para Categoria Dialógica; e Categoria M para a Categoria de Amalgama ou Duvidosa. Destacamos duas zonas e uma categoria de amalgama que se refere aos casos em que ou não conseguimos identificar elementos suficientes que caracterizassem uma das zonas de perfil.

As respostas foram categorizadas segundo os critérios a seguir em cada uma das categorias. A relação entre a categorização e as zonas pode não ser tão direta quanto possa parece à primeira vista. Primeiramente, que a análise qualitativa de respostas abertas pode ser subjetiva, necessitando a leitura atenta, e mecanismos para evitar modificação na categoria ao longo da análise. Para tanto, uma matriz de termos e expressões a serem utilizados para categorização das respostas.

Outra questão, é que as categorias autoritária e dialógica poderiam até ser assumidas como zonas, mas a categoria duvidosa não. Esta categoria é fruto da limitação dos dados e dos critérios que estabelecemos, e também pode representar a existência de outra zona de perfil que não se enquadra no recorte que realizamos.

Esta categoria pode representar a amalgama de mais de uma zona, isto é, em certos contextos o limite entre uma zona e outra pode ser muito tênue. Além disto, o perfil conceitual de um respondente poderia não ter as duas zonas. Algumas das respostas respondiam 
à pergunta não se adequando ao recorte teórico, como por exemplo, a reposta "É ampliar o conhecimento" dada à pergunta "O que é aprender?". As expressões-chave, referentes à categoria autoritária utilizadas para categorização das respostas, estão apresentadas na Tabela 5 e as relativas à categoria dialógica são apresentadas na Tabela 6 .

Tabela 5: Expressões típicas da zona autoritária

\begin{tabular}{ll}
\hline \hline Ensinar & Aprender \\
\hline Introduzir & Absorver \\
Transmitir & Adquirir \\
Passar & Assimilar \\
Mostrar & Receber \\
Fazer & Tomar conhecimento \\
Ministrar & Apropriar \\
& Acumular \\
\hline \hline
\end{tabular}

Tabela 6: Expressões típicas da categoria dialógica

\begin{tabular}{ll}
\hline \hline Ensinar & Aprender \\
\hline $\begin{array}{l}\text { Trocar experiências } \\
\text { Proporcionar condições para que o outro adquira }\end{array}$ & Conhecimento significativação com quem ensina de forma ativa \\
conhecimento & \\
$\begin{array}{ll}\text { Ajudar as pessoas a desenvolverem seu conhecimento } \\
\text { Possibilitar que o outro aprenda por si mesmo }\end{array}$ & Com reflexão \\
$\begin{array}{ll}\text { Estimular o aluno } \\
\text { Dividir conhecimento }\end{array}$ & \\
\hline \hline
\end{tabular}

A análise qualitativa é bastante complexa e propicia uma extensa proliferação de dados. Para reduzirmos os dados, como relatado anteriormente dividimos as questões em vários modelos de questionários. Além disso, utilizamos análises estatísticas para selecionar dados a serem analisados mais profundamente. Se realizássemos a análise de todos os pares de questões possíveis no questionário chegaríamos a cerca de 300 pares, o que é inviável de ser analisado em um trabalho de mestrado.

Utilizamos estatística descritiva para procurar indícios de relação entre as zonas de perfil conceitual de ensinar e de aprender. Neste sentido, trabalhamos com porcentagens das categorizações das respostas. 
Para categorização e análise das respostas, realizamos o planejamento e a construção de um banco de dados ${ }^{29}$. Após a transcrição de todas as respostas, o banco de dados facilitou a realização da categorização por questão, por respondente ou por categoria. Permitiu que agrupássemos as informações por indivíduo ou por grupos de indivíduos. Essa funcionalidade é importante quando desejamos selecionar as diferentes perguntas e agrupar respectivas categorizações e verificar correlações entre as mesmas.

Utilizamos alguns métodos estatísticos ao longo da análise. Por esse motivo, antes de utilizar cada método, apresentaremos brevemente o mesmo. Foram utilizados dois softwares estatísticos para realizar os testes: o SPSS 12.0 (versão em inglês) e o Statística 6.0 (versão em inglês).

Um dos métodos que utilizaremos é a estatística descritiva e exploratória. Tal análise refere-se à descrição de levantamentos realizados em porcentagens e contagem simples (BARBETA, 2003). É possível utilizar outros métodos para realizar tal estatística, contundo, nos ateremos basicamente à interpretação de tabelas e alguns gráficos.

Segundo os métodos estatísticos utilizados os resultados tiveram valores significativos e representativos. Utilizamos estes principalmente como ponto de partida para aprofundamento na análise qualitativa dos pares de questões que demonstraram correlação nos métodos. O uso da estatística fundamenta-se na proposta da pesquisa de trabalhar sobre o perfil conceitual da amostra enquanto grupo, e não de indivíduos isolados. As respostas a serem destacadas geralmente terão a função de exemplificar um fenômeno geral. Em algumas ocasiões destacamos algumas respostas que destoam do fenômeno mais comum.

\footnotetext{
${ }^{29} \mathrm{O}$ software utilizado foi o Microsoft Access 2007.
} 


\subsubsection{Caracterização da Amostra e Aplicação do questionário}

Os dados foram colhidos em uma turma de alunos de Licenciatura em Física do Instituto de Física da Universidade de São Paulo (IFUSP). O curso foi escolhido por considerarmos importante estudar os perfis conceituais de professores em formação, os conceitos ensinar e aprender determinam, em grande parte, como os futuros professores exercerão - ou exercem - a profissão. O curso de licenciatura em Física da USP foi escolhido por existir há algumas décadas, sendo uma das referências nacionais na área de formação de professores. Além disso, tínhamos acesso facilitado para a coleta de dados por estarmos vinculados ao programa de pós-graduação em Ensino de Ciências da mesma instituição.

Na USP, apesar de haver ingresso nos turnos diurno e noturno, existe alguma flexibilidade para que os estudantes freqüentem turmas em período diverso do escolhido originalmente. O curso recebe alunos de toda a cidade de São Paulo e mesmo de outras partes do Estado, não sendo incomum encontrar, entre o corpo discente, alunos que vieram de outros estados para fazer o curso na instituição.

A graduação em Física contava, no semestre da coleta de dados, com 1520 estudantes, sendo 699 da licenciatura e 720 do bacharelado, além de 101 estudantes freqüentando o curso como alunos especiais, ou em processo de adaptação. Esses últimos são, normalmente, recém formados em uma das outras modalidades ou provenientes de outras instituições, devendo ser aprovados no mínimo em 12 créditos para se tornarem alunos regulares. 
A amostra foi constituída a partir dos alunos da disciplina Elementos $e$ Estratégias para o Ensino de Física ${ }^{30}$, a qual é obrigatória no curso de Licenciatura em Física da USP. Apesar de alunos de vários estágios do curso freqüentarem a disciplina, a mesma consta no currículo do quinto período da licenciatura diurna e sétimo da noturna. A coleta de dados foi realizada no final do primeiro semestre letivo de 2006, mais precisamente na primeira semana de julho. Em tal semestre, foram oferecidas duas turmas da disciplina, uma noturna e outra diurna, sendo esta ultima a escolhida como amostra porque tivemos acesso facilitado pelo professor da disciplina para a coleta de dados.

Além da escolha da turma, não realizamos escolha prévia dos estudantes que responderiam aos questionários, constituindo a amostra a partir dos estudantes presentes no dia da avaliação final do curso.

A aplicação ocorreu sem nenhum incidente que acreditamos ter influenciado na coleta ou na qualidade dos dados. Aproximadamente $50 \%$ dos estudantes entregaram suas respostas em até 20 minutos de aplicação do questionário, 75\% com 30 minutos e apenas 5\% gastaram mais que 40 minutos para entregar. O tempo foi significativamente reduzido comparada a mais de uma hora gasta pelos estudantes para responder o questionário piloto.

Os modelos de questionário foram distribuídos de forma alternada e seqüencial de acordo com a posição de cada um dos estudantes sentados na sala de aula. Obtivemos 10 questionários respondidos de cada dos modelos de questionário.

\footnotetext{
${ }^{30}$ A ementa da disciplina encontra-se no Apêndice 2.
} 


\subsubsection{Condição enquanto professor}

Observamos na Tabela 7 que $14(35 \%)$ dos 40 estudantes lecionavam em algum tipo de ensino. Isso mostra que, apesar dos estudantes ainda estarem em um curso de formação de professores, cerca de um terço exerce de alguma forma a profissão.

Tabela 7: Situação quanto ao ato de lecionar ou não dos estudantes - julho/2006

\begin{tabular}{ccc}
\hline \hline Situação & Qt & \% \\
\hline Leciona & 14 & 35,0 \\
Não leciona & 26 & 65,0 \\
\hline Total & 40 & 100,0 \\
\hline \hline
\end{tabular}

Ainda se referindo à questão da prática docente procuramos determinar o tipo de prática em função do local de trabalho (“Onde leciona?”). Esses dados estão apresentados na Tabela 8. Os números de alunos que lecionavam em aulas particulares, no ensino médio e em cursinhos pré-vestibulares são próximos, com a prevalência dos que atuam no ensino médio. Identificamos um aluno, que é bacharel em Física pelo IFUSP e professor no ensino superior.

Tabela 8: Onde lecionavam os estudantes - julho/2006

\begin{tabular}{lrr}
\hline \hline Onde Leciona & Qt & \% \\
\hline Não leciona & 26 & 65,0 \\
Cursinho pré-vestibular & 4 & 10,0 \\
Médio & 6 & 15,0 \\
Aulas particulares & 3 & 7,5 \\
Superior & 1 & 2,5 \\
\hline Total & 40 & 100,0 \\
\hline \hline
\end{tabular}

Ainda se relacionando à prática pedagógica, realizamos a pergunta "Há quanto tempo leciona?", cujas respostas forneceram os dados apresentados na Tabela 9.

Quatro alunos indicaram que lecionam e não informaram há quanto. Cerca de $17,5 \%$ dos estudantes lecionavam há pelo menos três anos. Enquanto cerca de $10 \%$ lecionavam 
há um tempo maior que seu tempo de graduação na licenciatura em física. Isto pode indicar que a escolha do curso de graduação em física foi uma opção proveniente da prática em sala de aula.

Tabela 9: Há quanto tempo lecionavam os estudantes - julho/2006

\begin{tabular}{lrr}
\hline \hline Tempo & Qt & $\mathbf{\%}$ \\
\hline Não leciona & 26 & 65,0 \\
Não informou & 4 & 10,0 \\
Até um ano & 3 & 7,5 \\
De 1 a 3 anos & 4 & 10,0 \\
De 4 a 6 anos & 2 & 5,0 \\
Mais de 6 anos & 2 & 5,0 \\
\hline Total & 40 & 100,0 \\
\hline \hline
\end{tabular}

$\mathrm{Na}$ Tabela 10 são apresentados os dados referentes ao número de horas semanais no exercício da prática docente. Observamos que cerca de $15 \%$ dos respondentes lecionam até 6 horas semanais, e que todos os que atuam em cursinhos pré-vestibulares, têm esse valor como teto. Apenas três respondentes têm uma carga didática superior a 20 horas semanais, sendo que um desses atua no ensino superior.

Tabela 10: Onde lecionavam e carga horária semanal de prática docente dos estudantes - julho/2006

\begin{tabular}{lrrr}
\hline \hline \multicolumn{1}{c}{ Onde } & Horas-aula/semana & Qt & \multicolumn{2}{c}{$\%$} \\
\hline Não leciona & - & 26 & 65,0 \\
\hline \multirow{2}{*}{ Aula Particular } & Não informado & 2 & 5,0 \\
& 3 & 1 & 2,5 \\
\hline Cursinho pré-vestibular & até 6 & 4 & 10,0 \\
\hline \multirow{2}{*}{ Ensino Médio } & até 6 & 2 & 5,0 \\
& de 7 a 20 & 2 & 5,0 \\
\hline Ensino Superior & mais 20 & 2 & 5,0 \\
\hline Total & 24 & 1 & 2,5 \\
\hline \hline
\end{tabular}

\subsubsection{Dados relacionados ao Curso}

Toda a amostra (40 estudantes) foi constituída de alunos da licenciatura em Física do Instituto de Física da USP. Quanto ao turno em que cursavam, verificamos a partir da 
Tabela 11 que $90 \%$ dos estudantes era do curso diurno e apenas $10 \%$ eram do turno noturno. Predominância de alunos do diurno era esperada uma vez que a coleta de dados foi realizada numa turma do turno matutino.

Tabela 11: Turno que freqüentavam os estudantes - julho/2006

\begin{tabular}{lrr}
\hline \hline \multicolumn{1}{c}{ Turno } & Qt & $\mathbf{\%}$ \\
\hline Diurno & 36 & 90 \\
Noturno & 4 & 10 \\
\hline Total & 40 & 100 \\
\hline
\end{tabular}

O histórico acadêmico da amostra pode ser caracterizado a partir do estudo da formação anterior dos respondentes. Observamos, na Tabela 12, que cerca de $30 \%$ dos respondentes já tiveram experiência em outro curso de graduação. Sendo que $15 \%$ chegaram a completar outro curso. Uma parcela semelhante acabou abandonando outro curso antes do término. E é interessante que um dos estudantes leva outro curso de graduação em paralelo com o curso de licenciatura em Física.

Tabela 12: Outro curso superior que os estudantes freqüentavam(ram) - julho/2006

\begin{tabular}{lrr}
\hline \hline Curso & Qt & \% \\
\hline Não cursou & 28 & 70,0 \\
Abandonou & 5 & 12,5 \\
Completou & 6 & 15,0 \\
Cursando & 1 & 2,5 \\
\hline Total & 40 & 100,0 \\
\hline \hline
\end{tabular}

Observamos na Tabela 13, a proveniência dos estudantes da amostra. Cerca de $70 \%$ dos alunos entraram por meio de vestibular no curso. Alguns $(17,5 \%)$ vieram de outro curso por meio de transferência, seja de dentro da USP (transferência interna) ou de fora (transferência externa).

Tabela 13: Forma pela qual os estudantes ingressaram na licenciatura 


\begin{tabular}{lrr}
\hline \multicolumn{1}{c}{ Forma } & Qt & \multicolumn{1}{c}{$\mathbf{\%}$} \\
\hline Vestibular & 28 & 70,0 \\
Já Graduado & 4 & 10,0 \\
Transferência Interna & 4 & 10,0 \\
Transferência Externa & 3 & 7,5 \\
Não-informado & 1 & 2,5 \\
\hline Total & 40 & 100,0 \\
\hline \hline
\end{tabular}

Observamos na Tabela 14, que cerca de $17,5 \%$ dos estudantes eram provenientes do curso de Bacharelado em Física da USP, sendo que cerca de $10 \%$ vieram de cursos de outras instituições de ensino superior. Um dos estudantes cursou o curso de Engenharia Civil nos Estados Unidos.

Tabela 14: Forma de ingresso, instituição e curso de origem dos estudantes

\begin{tabular}{lllrr}
\hline Forma de Ingresso & Curso de origem & Instituição & Qt & \% \\
\hline \multirow{3}{*}{ Já Graduado } & Bacharelado em Física & IFUSP & 3 & 7,5 \\
& Matemática & Não Informada & 1 & 2,5 \\
& Civil Engineer & Texas A\&M University & 1 & 2,5 \\
\hline \multirow{2}{*}{ Transferência Externa } & Meteorologia & Não Informado & 1 & 2,5 \\
& Não Informado & UNESP - Bauru & 2 & 5,0 \\
\hline Transferência Interna & Bacharelado em Física & IFUSP & 4 & 10,0 \\
\hline Vestibular & & & 28 & 70,0 \\
\hline Total & & & 40 & 100,0 \\
\hline \hline
\end{tabular}

$\mathrm{Na}$ Tabela 14, observamos que 7,5\% dos estudantes obtiveram primeiro o diploma de Bacharel em Física antes de procurar a Licenciatura. Dez porcento da amostra desistiu do curso de Bacharelado em Física do IFUSP e se transferiu para a Licenciatura.

Verificamos, na Tabela 15, que os estudantes em sua maioria (75\%) cursam a disciplina no semestre esperado do curso, uma vez que entraram na Licenciatura em 2004 e a disciplina, oferecida no primeiro semestre de 2006, é do quinto período curricular da Licenciatura diurna. Apenas 7,5\% dos estudantes ingressaram no curso a partir do vestibular em anos anteriores a 2004. Os outros $10 \%$ de estudantes ingressantes antes de 2004 são provenientes 
de algum tipo de transferência. A transferência pode ser interna, quando o aluno vem de outro curso da USP e externa caso venha de outra instituição.

Tabela 15: Ano e forma de ingresso dos estudantes na Licenciatura

\begin{tabular}{llrr}
\hline \hline Ano & Forma de Ingresso & Qt & \multicolumn{2}{c}{$\%$} \\
\hline \multirow{2}{*}{2000} & Transferência Interna & 1 & 2,5 \\
& Transferência Externa & 1 & 2,5 \\
\hline 2002 & Transferência Interna & 1 & 2,5 \\
\hline \multirow{2}{*}{2003} & Vestibular & 3 & 7,5 \\
& Transferência Externa & 1 & 2,5 \\
\hline \multirow{2}{*}{2004} & Vestibular & 25 & 62,5 \\
& Transferência Interna & 2 & 5,0 \\
& Já Graduado & 3 & 7,5 \\
\hline 2005 & Já Graduado & 2 & 5,0 \\
\hline 2006 & Transferência Externa & 1 & 2,5 \\
\hline Total & & 40 & 100,0 \\
\hline \hline
\end{tabular}

Observamos na Tabela 16 que a maior parte (70\%) dos estudantes da amostra estavam entre o quarto e o sexto semestre do curso. Isso era esperado uma vez que a disciplina consta no quinto período da licenciatura diurna. Para realizarmos a conversão utilizamos a média de 20 créditos por semestre para os estudantes do diurno e 16 para o noturno. Contudo, é possível encontrar estudantes no início do curso (até o terceiro semestre) e ao final (oitavo e nono semestres $\left.{ }^{31}\right)$.

Tabela 16: Semestre que cursam e número de créditos dos estudantes - julho/2006

\begin{tabular}{llrr}
\hline \hline Semestre & \multicolumn{1}{c}{ Créditos } & Qt & \multicolumn{1}{c}{$\%$} \\
\hline $3^{\mathrm{o}}$ & entre 60 e 80 & 1 & 2,5 \\
$4^{\mathrm{o}}$ & entre 80 e 100 & 7 & 17,5 \\
$5^{\mathrm{o}}$ & entre 100 e 120 & 17 & 42,5 \\
$6^{\mathrm{o}}$ & entre 120 e 140 & 8 & 20,0 \\
$7^{\mathrm{o}}$ & entre 140 e 160 & 5 & 12,5 \\
$8^{\mathrm{o}}$ e $9^{\mathrm{o}}$ & entre 160 e 200 & 2 & 5,0 \\
\hline \hline
\end{tabular}

\footnotetext{
${ }^{31}$ Alguns alunos provenientes de outros cursos, e mesmo de transferência interna possuem alguns créditos que não se constam na grade curricular da licenciatura.
} 


\subsubsection{Sexo (Gênero)}

Observamos na Tabela 17 que quarenta e três porcento da amostra eram do gênero feminino, enquanto que a maior parte $58 \%$ eram do masculino.

Tabela 17: Gênero dos estudantes

\begin{tabular}{lcc}
\hline \hline Gênero & Qt & \% \\
\hline Feminino & 17 & 42,5 \\
Masculino & 23 & 57,5 \\
\hline Total & 40 & 100,0 \\
\hline \hline
\end{tabular}

\subsubsection{Religião}

Uma das perguntas refere-se à religião que professavam os respondentes. A questão foi formulada para permitir qualquer resposta, não tendo uma lista de possibilidades. Isso levou a cerca de doze categorias possíveis, além de uma que se refere aos que não responderam à questão. A falta de um conjunto de categorias a priori causou dispersão indesejada dos indivíduos entre as diversas categorias que se sobrepunham, como pode ser verificado na Tabela 18. Há o caso, por exemplo, de 5\% dos indivíduos que respondeu ser cristão, mas dentre as categorias colhidas várias eram cristãs. Numa aplicação futura propomos a criação de uma matriz de possibilidades, sobretudo subdividindo as religiões cristãs. A questão teve alcance limitado, pois $25 \%$ dos indivíduos não responderam à questão.

O que pudemos identificar com maior clareza é que cerca de $23 \%$ da amostra identificou-se como sendo católica, 10\% como protestante e cerca de $8 \%$ como teísta, espírita ou não professa nenhuma crença em cada categoria. 
Tabela 18: Religião dos estudantes - julho/2006

\begin{tabular}{lrr}
\hline \multicolumn{1}{c}{ Religião } & Qt & \multicolumn{1}{c}{ \% } \\
\hline Não informado & 10 & 25,0 \\
Católica & 9 & 22,5 \\
Protestante & 4 & 10,0 \\
Teísta & 3 & 7,5 \\
Espírita & 3 & 7,5 \\
Nenhuma & 3 & 7,5 \\
Cristã & 2 & 5,0 \\
Agnóstico & 1 & 2,5 \\
Animismo Colérico & 1 & 2,5 \\
Ateísta & 1 & 2,5 \\
Misto-Não definida & 1 & 2,5 \\
Neutra & 1 & 2,5 \\
Xüi, mistura várias & 1 & 2,5 \\
\hline Total & 40 & 100,0 \\
\hline \hline
\end{tabular}

\subsection{Análise dos dados}

Propusemos as perguntas de trabalho no desenvolvimento do problema de pesquisa no Capítulo 2. Utilizamos testes estatísticos como critério para reduzir os dados e, ao mesmo tempo, como ponto de partida para análise qualitativa das perguntas de pesquisa. Por este motivo, apresentamos brevemente, a seguir, aspectos teóricos relacionados às estatísticas usadas. Após a introdução aos métodos, reapresentaremos as perguntas de pesquisa e suas respectivas hipóteses a serem verificadas. Em seguida, apresentaremos a aplicação da análise estatística e a análise qualitativa final. Os testes estatísticos normalmente são baseados no teste de hipóteses. Cada pergunta que se quer responder possui, normalmente, duas hipóteses. Uma chamada de hipótese nula e outra chamada hipótese alternativa ou de trabalho. A hipótese de trabalho é, na prática, algo que esperamos ser verdadeiro. Como não é possível afirmar que algo sempre é verdadeiro, busca-se rejeitar uma hipótese contrária (hipótese nula) para se poder assumir como verdadeira a hipótese de trabalho. A hipótese nula $\left(\mathrm{H}_{0}\right)$ é uma hipótese presumida verdadeira até 
que um teste estatístico a refute, na prática, é o inverso do que queremos testar como verdadeiro. Caso $\mathrm{H}_{0}$ seja rejeitada, assume-se a hipótese de trabalho $\left(\mathrm{H}_{1}\right)$ como verdadeira (BARBETTA, 2006), comprovando o que se pretendia testar. Caso não seja possível rejeitar a hipótese nula, esta é assumida como verdadeira, de acordo com os critérios do método estatístico utilizado. A criação das hipóteses ficará mais clara quando retomarmos as perguntas de pesquisa com suas respectivas hipóteses.

A probabilidade de significância ou nível descritivo encontrada em um teste estatístico (designada costumeiramente por " $p$ ”) refere-se à relação entre duas variáveis. Obter um valor significativo, quer dizer que os resultados ou as correlações identificadas não são fruto de acaso ou flutuação estatística. Isto é, que a probabilidade das variáveis aserem medidas quando o valor é significativo quer dizer que não é fruto de uma distribuição aleatória. Encontrar valores significativos para o nível descritivo quer dizer que, tendo informações de uma variável, é mais provável identificar certo valor para a outra variável.

O valor ser significativo quer dizer que o nível descritivo é menor que o nível de significância assumido. Isto é, o valor máximo aceito do nível descritivo é chamado de nível de significância (designado normalmente por $\alpha$ ), que na prática, é o valor de probabilidade tolerável para rejeitar $\mathrm{H}_{0}$. Em outras palavras, valores inferiores ao nível de significância indicam que o fenômeno analisado não é aleatório e existe uma relação causal entre as variáveis. O nível de significância é estabelecido de acordo com os fenômenos analisados e costumam ser específicos de cada área de estudo. Normalmente, na aplicação do teste nas ciências humanas, assumem-se valores de até 0,05 (5\%) para o nível de significância (BARBETTA, 2003). É possível aumentar o nível de significância para se analisar um fenômeno. Entretanto, ao elevar o valor de $\alpha$, o erro do teste também é elevado. Nesta pesquisa optamos pelo valor padrão de $5 \%$ para todos os testes realizados. 
Além de estabelecer um nível de significância apropriado ao realizar um teste estatístico, é importante se ter uma amostra que represente o universo de pesquisa adequadamente. No caso desta pesquisa, optamos por estudar uma turma da licenciatura em Física, sem generalizar para todo o curso, e por isto, a amostra escolhida é igual ao universo de pesquisa.

Ao rejeitarmos a hipótese nula e assumirmos a hipótese de trabalho como verdadeira quer dizer que a modificação de uma variável implica a modificação da variável analisada. Para saber quais categorias se relacionam, utilizamos tabelas de dupla entrada. Uma tabela de dupla entrada é criada colocando-se os valores de uma variável nas colunas e de outra variável nas linhas. Na Tabela 19, como exemplo, colocamos a freqüência da categorização entre as cores de cabelos e os gêneros de uma amostra fictícia.

Tabela 19: Exemplo de tabela de dupla entrada: Relação entre cabelo e gênero (amostra fictícia)

\begin{tabular}{|c|c|c|c|c|c|}
\hline & \multicolumn{5}{|c|}{ Cabelo } \\
\hline & & Loiro & Preto & Ruivo & Total \\
\hline \multirow{3}{*}{ 方 } & Homem & 2 & 12 & 0 & 14 \\
\hline & Mulher & 6 & 4 & 2 & 12 \\
\hline & Total & 8 & 12 & 2 & 26 \\
\hline
\end{tabular}

Assim, a partir da Tabela 19, podemos afirmar que os cabelos de 2 homens eram loiros, 12 pretos e nenhum ruivo. Dos cabelos das mulheres 6 eram loiros, quatro pretos e 2 ruivos. O total de linhas dará o total da amostra por gênero, a primeira linha aponta 14 homens e a segunda 12 mulheres. O total de coluna caracteriza a população de acordo com a cor dos cabelos, isto é, são 8 cabelos loiros, 12 loiros e 2 ruivos. Tanto a soma dos totais de coluna quanto o de linha nos fornecem a amostra total, no caso 26. Neste tipo de tabela, é possível se identificar a contagem a distribuição da amostra por seguimentos. 
A seguir, apresentamos novamente cada uma das perguntas de trabalho e a formulação das hipóteses de cada uma destas. E, em seguida, discutiremos brevemente os testes estatísticos quando da primeira utilização de cada um.

Pergunta 1: Os enunciados das questões, em um questionário, são capazes de delimitar determinados contextos?

$H_{0}$ : $O$ enunciado das questões não é suficiente para definir contextos.

$\mathrm{H}_{1}$ : $\mathrm{O}$ enunciado das questões é suficiente para definir contextos.

Como discutimos no CAPÍTULO 1:, a delimitação de um contexto ocorre na interação, por meio de elementos presentes na comunicação. A hipótese de trabalho da Pergunta 1 pressupõe que o enunciado da questão fornece as regras de reconhecimento, enquadramento e realização para a utilização das zonas de perfil conceitual.

Pergunta 2: Há uma relação entre as zonas dos perfis conceituais de ensinar e aprender?

$H_{0}$ : Não há relação entre as zonas dos perfis conceituais dos conceitos de ensinar e de aprender.

$H_{1}$ : Há relação entre as zonas dos perfis conceituais dos conceitos de ensinar e de aprender.

Procuramos com essa pergunta verificar, a partir do pressuposto que existem zonas de perfil "espelhadas", se uma mesma zona existe para ensinar e para aprender. Procuraremos verificar, através dos testes, se existe uma relação entre as categorizações. Por exemplo, se existe uma resposta a uma pergunta categorizada na Categoria Autoritária, pode-se verificar se em outra pergunta, o padrão correlacionado tende a se modificar ou ser categorizado da mesma forma. Por exemplo, pode ser que a categorização feita em Q1 como Autoritária, pode ser relacionada à categorização feita em Q2 como Dialógica. 
$\mathrm{Na}$ presente pesquisa, diferentemente do exemplo, criamos tabelas de dupla entrada com uma pergunta nas colunas e outra nas linhas, e tanto coluna como linhas exprimem categorizações das mesmas categorias. É importante destacar, que a correlação pode não ocorrer diretamente. Por exemplo, a zona dialógica para uma pergunta Q05 pode se correlacionar com a zona autoritária na pergunta Q12.

A hipótese de trabalho desta pergunta de pesquisa parte do pressuposto que temos pares de zonas do perfil conceitual de ensinar e aprender. Ou seja, as zonas do perfil conceitual de ensinar têm reflexo no perfil de aprender.

Pergunta 4: É possível verificar se os licenciandos alternam suas posições de professor e aluno conforme a questão?

$\mathrm{H}_{0}$ : Os estudantes assumem apenas uma posição, seja de professor ou de aluno, ao longo de todo o questionário.

$H_{1}$ : Os estudantes assumem posição de aluno ou de professor dependendo da questão a que respondem.

Em Viggiano e Mattos (2005) encontramos indícios que os estudantes mudam de posição ao responderem as questões do questionário. Isto porque, questões idênticas - salvo a substituição de "ensinar" por "aprender" - levaram a respostas categorizadas em categorias “antagônicas", isso mostra que as zonas dos perfis (assumindo que os contextos eram semelhantes) eram utilizadas independentemente e mesmo antagonicamente. Por isso, mesmo antes da análise estatística, possuíamos alguns indicativos qualitativos nas respostas que a hipótese nula da Pergunta 4 é falsa.

A confirmação da hipótese de trabalho reafirma a importância da necessidade dos licenciandos conhecerem seus perfis conceituais de ensinar e de aprender, de forma a se 
engajarem ativamente nas práticas discentes e docentes. Neste sentido, compreender como suas zonas de perfil conceitual são usadas nos diferentes contextos é fundamental para a preparação de estratégias que facilitem o processo comunicativo nas situações de ensino-aprendizagem.

\subsubsection{Comparação dos modelo de questionários}

Para verificar a relação entre os questionários utilizamos o método estatístico Teste de Pearson (BARBETA, 2003). Este se refere ao chamado coeficiente de correlação linear de Pearson (r). Este coeficiente é obtido por meio da estatística de variáveis quantitativas, como por exemplo, a contagem da freqüência de uma categorização. Ele permite não somente verificar a relação entre as variáveis, mas também o grau da correlação. Isto é, além de fornecer um valor de probabilidade de significância, fornece uma intensidade a partir do coeficiente de correlação linear. O coeficiente não pode depender da unidade de medida dos dados e seu valor fica compreendido entre -1 e +1 . Quando o valor é positivo, dizemos que a correlação é direta, isto é, as variáveis são diretamente proporcionais, se o valor de uma variável aumenta ou diminui, o valor da outra também aumenta ou diminui respectivamente. Pode também ser uma correlação inversa $(r<0)$, isto é, se o valor de uma variável aumenta o da outra diminui. Quanto mais $r$ se aproxima dos extremos $(-1$ e +1$)$ mais forte é a correlação entre as variáveis. Os extremos indicam correlação integral e que o fenômeno é diretamente causal. Isto é, se identificamos, por exemplo, uma correlação positiva igual a +1 entre as categorias $\mathrm{A}$ e B, sempre que a categorização for A para uma variável, na outra variável o valor será B. Para coeficientes entre 0 e 0,3 a correlação é considerada fraca, entre 0,3 e 0,5 a correlação é moderada, entre 0,5 e 0,8 a correlação é forte e acima de 0,8 a correlação é muito forte (MUIJS, 
2004). Consideraremos nas análises que seguem dados cujo nível de significância é sempre maior que o nível descritivo.

Em cima das frequiências das categorizações das respostas da amostra ao questionário, realizamos o teste de correlação linear de Pearson $^{32}$ para as questão categorizadas nas dimensões Concepções de Educação e Onde. A correlação foi realizada com base em contexto mais aberto, desconsiderando a especificidade de ensinar e aprender. Apresentamos, respectivamente, na Tabela 20 e na Tabela 21 os valores de correlação das dimensões Concep̧̧ões de Educação e Onde, para cada agrupamento de questões coincidentes em cada um dos modelos de questionário, como ilustrado na Figura 3.

Tabela 20: Correlação entre as categorizações das respostas coincidentes nos questionários na Dimensão Concepções de Educação

\begin{tabular}{cc}
\hline \hline Questionários & Correlação de Pearson* \\
\hline W e Y & 0,764 \\
\hline W e Z & 0,729 \\
\hline X e Y & 0,831 \\
\hline X e Z & 0,793 \\
\hline \hline Todos as correlações se mostraram significantes a $\alpha=0,01$
\end{tabular}

Tabela 21: Correlação entre as categorizações das respostas coincidentes nos questionários na Dimensão Onde

\begin{tabular}{cc}
\hline \hline Questionários & Correlação de Pearson* \\
\hline W e Y & 0,902 \\
\hline W e Z & 0,858 \\
\hline X e Y & 0,828 \\
\hline X e Z & 0,821 \\
\hline \hline Todos as correlações se mostraram significantes a $\alpha=0,01$
\end{tabular}

Todos os valores de correlação se mostraram significantes para a Tabela $21 \mathrm{e}$ para a Tabela 22, uma vez todos os níveis descritivos encontrados foram inferiores a 0,01 , bem menores que os $5 \%$ assumidos como padrão. Por esse motivo, os índices de significância foram omitidos das tabelas.

\footnotetext{
${ }^{32}$ Utilizando o pacote estatístico C SPSS 12 for Windows, Release 12.0.0 produzido pela LEAD Technologies, Inc.
} 
As correlações encontradas são positivas e fortes ou muito fortes, implicando na rejeição da hipótese nula ${ }^{33}$. Portanto a inserção das questões em qualquer um dos modelos de questionário leva a resultados semelhantes. Logo, espera-se que se os questionários forem aplicados em outras amostras - que representem bem a mesma população -, a categorização seja semelhante à obtida, apontando para a equivalência entre os questionários.

Além disso, tal correlação nos trás indícios, que ao trabalharmos com pares de questões, construídas a partir de categorias a priori, podemos chegar - em contextos similares à utilização de zonas de perfil conceitual semelhantes, independentemente do tipo de agrupamento das questões. Isto é, a parte comum de uma questão, que independe de ensinar ou aprender, é suficiente para estabelecer as regras de reconhecimento, enquadramento e realização de contexto, sendo por si só suficiente para definir um contexto e implicar na utilização de certa categoria.

\subsubsection{Correlações entre as categorias}

As questões foram numeradas de acordo com a ordem na qual apareceram no questionário. Para se referir a uma questão utilizamos a letra "Q" seguida do número que representa sua posição neste questionário, além disso, colocamos a letra "A" quando a questão se referia a aprender e "E" quando se referia a ensinar (e.g. Q01A, questão 01 relativa ao conceito de aprender; Q05E, questão 05 relativa ao conceito de ensinar). Quando fizemos a análise considerando-se apenas a raiz da questão (contexto mais geral) utilizamos apenas a letra Q seguida do número da questão no questionário (e.g. Q19). Para nos referirmos a uma resposta fornecida a uma questão, utilizamos a notação da questão seguida de um hífen e o número do

\footnotetext{
${ }^{33} \mathrm{H}_{0}$ : As categorizações das respostas não dependem do questionário utilizado.
} 
estudante que a forneceu (e.g. Q12A-005, resposta do estudante 005 fornecida à questão 12 relativa ao conceito de aprender).

A partir da categorização de todas as respostas na dimensão Concepções de Educação, em uma primeira etapa, aplicamos o teste qui-quadrado de todas as perguntas com todas as perguntas de cada um dos modelos de questionários. O teste estatístico quiquadrado $^{34}$ se aplica a variáveis qualitativas (BARBETTA, 2003; MUIJS, 2004) como, por exemplo, a categorização das respostas do questionário. Utilizamos o nível de significância do teste como 5\%. Dessa forma, pudemos identificar as questões com correlação entre as categorizações, isto é, tais questões podem indicar a rejeição das hipóteses nulas das Perguntas 1 e 2. Além do nível descritivo, utilizamos tabelas de dupla entrada com as freqüências das categorias observadas para complementar a análise de cada par de questões.

Os valores de $p$ de cada uma desses agrupamentos pode ser encontrado na Tabela 22. As correlações não foram aplicadas às questões Q02, Q08, Q13, Q20 e Q23, pois estas não tiveram suas respostas categorizadas. A dimensão Concepções de Educação não se mostrou adequada para categorizar, pois todas as respostas foram categorizadas como amalgamada ou duvidosa. Mesmo que fossem categorizadas, não cumpririam os critérios de validade do teste, pois não teriam o número suficiente de respostas com categorizadas distintas para a aplicação do teste. A falta de variedade na categoria indica que os elementos textuais da questão não forneceram elementos suficientes para que uma ou outra zona fosse utilizada, em outras palavras, não ocorreu o delineamento de um contexto para o uso das zonas dos perfis conceituais em questão.

\footnotetext{
${ }^{34}$ A descrição completa da estatística do teste pode ser encontrada em Barbetta (2003).
} 
Construímos a Tabela 22 com os pares de questões com valores da probabilidade de significância menores que o nível de significância, ou seja, que indicam correlação entre as categorias das questões.

Tabela 22: Questões com nível descritivo do teste qui-quadrado menor que $5 \%$.

\begin{tabular}{|c|c|c|c|c|}
\hline \multicolumn{2}{|l|}{ Questão } & \multicolumn{2}{|c|}{ Questão } & \multirow{2}{*}{$\frac{\boldsymbol{p}}{0,0051}$} \\
\hline Q01A & O que é aprender? & Q04A & Como se aprende fora da escola? & \\
\hline Q03A & Como se aprende? & Q11A & Como se aprende com a televisão na escola? & 0,0257 \\
\hline Q04A & Como se aprende fora da escola? & Q09A & Como se aprende com a televisão na escola? & 0,0471 \\
\hline Q07A & $\begin{array}{l}\text { De quais formas podemos aprender } \\
\text { com um colega na escola? }\end{array}$ & Q11A & Como se aprende com a televisão na escola? & 0,0456 \\
\hline Q03E & Como se ensina? & Q07E & $\begin{array}{l}\text { De quais formas podemos ensinar um colega } \\
\text { na escola? }\end{array}$ & 0,0448 \\
\hline Q04E & Como se ensina fora da escola? & Q07E & $\begin{array}{l}\text { De quais formas podemos ensinar um colega } \\
\text { na escola? }\end{array}$ & 0,0318 \\
\hline Q16E & O que é ensinar física? & Q17E & Como se ensina física? & 0,0009 \\
\hline Q19E & Como se ensina física mal? & Q21E & Como se ensina em um convento? & 0,0352 \\
\hline Q14A & Como se aprende a jogar futebol? & Q21A & Como se aprende em um convento? & 0,0436 \\
\hline Q17A & Como se aprende física? & Q19A & Como se aprende física mal? & 0,0500 \\
\hline Q01A & O que é aprender? & Q19E & Como se ensina física mal? & 0,0067 \\
\hline Q04A & Como se aprende fora da escola? & Q19E & Como se ensina física mal? & 0,0541 \\
\hline $\mathrm{Q} 03 \mathrm{~A}^{35}$ & Como se aprende? & Q18A & Como se aprende física bem? & 0,0350 \\
\hline Q07A & $\begin{array}{l}\text { De quais formas podemos aprender } \\
\text { com um colega na escola? }\end{array}$ & Q12A & Como se aprende com o livro na escola? & 0,0404 \\
\hline Q09A & $\begin{array}{l}\text { Como se aprende com a televisão } \\
\text { na escola? }\end{array}$ & Q21A & Como se aprende em um convento? & 0,0222 \\
\hline Q11A & $\begin{array}{l}\text { Como se aprende com a televisão } \\
\text { na escola? }\end{array}$ & Q14A & Como se aprende a jogar futebol? & 0,0371 \\
\hline Q04E & Como se ensina fora da escola? & Q22E & O que é ensinar física mal? & 0,0402 \\
\hline Q09E & $\begin{array}{l}\text { Como se ensina com a televisão na } \\
\text { escola? }\end{array}$ & Q17E & Como se ensina física? & 0.0034 \\
\hline Q09E & $\begin{array}{l}\text { Como se ensina com a televisão na } \\
\text { escola? }\end{array}$ & Q17E & Como se ensina física? & 0.0222 \\
\hline Q11E & $\begin{array}{l}\text { Como se ensina com a televisão na } \\
\text { escola? }\end{array}$ & Q14E & Como se ensina a jogar futebol? & 0,0348 \\
\hline
\end{tabular}

\subsubsection{Análise das questões Q01A (O que é aprender?) e Q04A (Como se aprende fora da} escola?)

A dimensão utilizada para se construir a pergunta Q01A foi $O$ que é?. Enquanto que Q04A foi baseada na categoria Onde?/Não-formal e na dimensão Como?.

\footnotetext{
${ }^{35}$ Pares de questõe destacados em cinza não devido à extensão e delimitação desta pesquisa.
} 
O nível descritivo encontrado no teste qui-quadrado foi 0,0051 , considerada fortemente significativa para $\alpha=0,05$. Na Tabela 23 dispusemos a contagem das respostas em cada categoria para as duas questões.

Tabela 23: Contagem da categorização das respostas das perguntas Q01A e Q04A em Concepções de Educação.

\begin{tabular}{r|r|r|r|r|r}
\hline \multicolumn{9}{c}{ Q04A } \\
\hline & & M & D & \multicolumn{1}{c}{ A } & Total \\
\hline \multirow{2}{*}{$\Xi$} & M & 2 & 5 & 0 & 7 \\
\cline { 2 - 6 } & $\mathrm{D}$ & 1 & 0 & 2 & 3 \\
\cline { 2 - 6 } & $\mathrm{A}$ & 6 & 4 & 0 & 10 \\
\hline & Total & 9 & 9 & 2 & 20 \\
\hline \hline
\end{tabular}

Legenda: M - Duvidosa; D - Dialógica; A - Autoritária

Quase metade (9) das respostas foi categorizada na categoria duvidosa na Q04A e 7 em tal categoria na Q01A. Em 18 casos, a categorização das respostas das duas perguntas foi diferente, sendo que os dois casos de mesma categorização ocorreram na categoria duvidosa. Isto indica que a modificação dos enunciados das perguntas incitaram respostas em categorias diferentes. Percebemos que seis das respostas categorizadas como duvidosas na Q04A foram categorizadas em autoritárias na Q01A.

Identificamos que Q01A possuiu um maior número de respostas categorizadas como autoritárias que Q04A. Portanto, o contexto definido por Q04A parece privilegiar a categoria autoritária se comparada com Q01A. A categoria predominante para as duas perguntas foi a autoritária, logo as duas questões definem contextos que privilegiam tal categoria.

Tabela 24: Seleção de respostas e categorização em Concepções de Educação de Q01A e Q04A

\begin{tabular}{l|lr|ll}
\hline \hline ES & Q01A - O que é aprender? & C & Q04A - Como se aprende fora da escola? & C \\
\hline \hline 001 & $\begin{array}{l}\text { Aprender é fazer com que o conhecimento } \\
\text { fique com você. }\end{array}$ & $\mathrm{M}$ & $\begin{array}{l}\text { Observando as situações do cotidiano e não repetindo } \\
\text { os erros. }\end{array}$ & M \\
\hline 002 & $\begin{array}{l}\text { Aprender não é objetivo nem racional; é } \\
\text { subjetivo e emocional. Não é acumular } \\
\text { dados ou conhecimento. É discutir. Mesmo } \\
\text { que não se obtenha respostas. Aprender é } \\
\text { formular perguntas (não respondê-las). } \\
\text { Não creio em Verdade Absoluta. }\end{array}$ & $\mathrm{D}$ & Espontaneamente. & $\mathrm{A}$ \\
\hline 008 & $\begin{array}{l}\text { Aprender não é somente na escola, } \\
\text { estudando as matérias regulares, o }\end{array}$ & $\mathrm{M}$ & $\begin{array}{l}\text { Quando nos vemos em situações desconfortáveis. em } \\
\text { conversas com amigos, pais. }\end{array}$ & $\mathrm{D}$ \\
\hline \hline
\end{tabular}




\begin{tabular}{|c|c|c|c|c|}
\hline ES & Q01A - O que é aprender? & $\mathbf{C}$ & Q04A - Como se aprende fora da escola? & $\mathbf{C}$ \\
\hline & $\begin{array}{l}\text { aprendizado se faz desde o momento em } \\
\text { que nascemos. }\end{array}$ & & & \\
\hline 023 & $\begin{array}{l}\text { Assimilar e desenvolver conhecimentos e } \\
\text { habilidades }\end{array}$ & $\mathrm{A}$ & $\begin{array}{l}\text { Observando o mundo, lendo e interagindo com outras } \\
\text { pessoas e c/ o mundo. }\end{array}$ & M \\
\hline 025 & É conseguir utilizar o que foi aprendido. & $\mathrm{M}$ & Vivenciando. & $\bar{M}$ \\
\hline 026 & $\begin{array}{l}\text { Aprender é apreender as informações que } \\
\text { são transmitidas }\end{array}$ & A & Observando, analisando, pesquisando & $\mathrm{D}$ \\
\hline 028 & $\begin{array}{l}\text { Assimilar conhecimentos e saber utilizá-lo } \\
\text { de forma criativa. }\end{array}$ & A & $\begin{array}{l}\text { Em bibliotecas, internet, em práticas simples realizadas } \\
\text { em casa, etc. }\end{array}$ & M \\
\hline 030 & $\begin{array}{l}\text { Aprender é assimilar, adquirir } \\
\text { conhecimentos. Não é gravar. É assimilar e } \\
\text { acomodar novas informações. }\end{array}$ & A & $\begin{array}{l}\text { Através de práticas sejam elas voluntárias ou não; de } \\
\text { discussões e debates; através de documentários; filmes; } \\
\text { leituras de livros... }\end{array}$ & $\mathrm{D}$ \\
\hline 032 & $\begin{array}{l}\text { É adquirir algum conhecimento sobre um } \\
\text { ou vários assuntos podendo com isso } \\
\text { explicar determinados fatos ou situações }\end{array}$ & A & $\begin{array}{l}\text { Lendo, observando, sendo curioso, pesquisando por } \\
\text { conta própria, conversando com pessoas que dominam } \\
\text { outros assuntos melhor do que eu. }\end{array}$ & $\mathrm{D}$ \\
\hline 040 & Entender e armazenar esse conhecimento & $\mathrm{A}$ & Observando & $\bar{M}$ \\
\hline
\end{tabular}

Legenda: M - Duvidosa; D - Dialógica; A - Autoritária

As respostas Q01A/Q04A-001, por exemplo, constituíram um dos dois pares nos quais a categorização praticamente se manteve. A resposta à questão Q01A do estudante 001 (Q01A-001) foi categorizada como duvidosa, pois o estudante refere-se apenas ao produto do aprender, e não ao processo. Neste sentido, o verbo "ficar" com o indivíduo, que se refere ao conhecimento, é fruto do processo aprender. Como não foi explicitada pelo estudante a forma como esse conhecimento foi tratado na relação, não é possível distinguir entre as categorias autoritária e dialógica. Em Q04A-001 o estudante utiliza o verbo observar, mas não qualifica este ato. Dependendo do sentido atribuído à observação, teremos classificações diferentes. O respondente refere-se a aprender com os erros, porém a incerteza se mantém, pois isso pode se estabelecer tanto numa relação autoritária, na qual o sujeito é condicionado por meio de punição ou estímulos negativos a não repetir os erros como pode ser dialógica, na qual o erro pode ser encarado como um auxiliar para uma construção compartilhada de conhecimento.

O Estudante 002 destaca em Q01A-002 que a aprendizagem "Não é acumular dados ou conhecimento, questionando a transmissão de uma "Verdade Absoluta". Parece indicar implicitamente, ao referir-se ao "acumular dados ou conhecimento", visão que de aprender enquanto "acúmulo de conhecimento", discordando desta idéia. Neste sentido, ele pode saber 
que existem várias formas de se conceber ensinar e aprender. Na resposta à Q04A, o Estudante 002 não se refere ao aprendiz e a quem ensina, ignorando a relação com o outro e as questões subjetivas e emocionais que caracterizou em Q01A. É possível identificar um descompasso entre aprender (sem contexto específico) e aprender em um ambiente informal. Essa leitura nos indica que as regras de reconhecimento utilizadas são diferentes, estabelecendo contextos distintos, o que permite a utilização de regras de realização diferentes, que levam à utilização de zonas de perfil conceitual distintas em cada uma das perguntas.

Com relação às categorias autoritária e dialógica, o Estudante 008, em sua resposta à questão Q01A, não nos permite identificar com clareza o que entende por aprender. $\mathrm{Na}$ resposta Q01A-008, refere-se à dimensão onde, deixando claro que o aprender não ocorre somente na escola (aprendizado formal). Desta forma, há indícios que acredita na existência de vários contextos em que se aprende. A resposta mostra que o entendimento da questão se deu em um foco no qual não foi possível identificar qual das categorias de análise seria mais adequada à resposta, por este motivo utilizamos a categoria duvidosa. De alguma forma, na Q01A, E008 antecipa a resposta à Q04A, nos permitindo a comparação entre Q01 A-008 e Q04A-008. Ao usar o termo “desconfortáveis" em Q04A, E008 qualifica o onde se dá o aprendizado, com elementos subjetivos e complementa com o aprendizado com amigos e pais. Assim, caracteriza a dimensão Onde?, simultaneamente com a dimensão Como? e Quem?. Esta pergunta permitiu, no caso desse estudante, a uma ampliação dos quadros de referência de contextos, pois outros elementos de outras categorias diversas do foco da questão foram trazidos a baila.

O Estudante 008 salienta em Q01A, que “o aprendizado se faz desde o momento em que nascemos", o que nos permite inferir que se refere à dimensão Quando aprender. A idéia de temporalidade pode ser interpretada a partir do princípio comunicativo interativo. Ao referir-se à questão temporal, que se relaciona ao princípio comunicativo 
interativo, Assim, o Estudante 008 dá relevo a um dos princípios que regem os contextos, situando o porquê utiliza uma ou outra zona de perfil.

O Estudante 023 refere-se a "assimilar" (Q01A-023) um conhecimento ou habilidade. A assimilação remete à idéia de um aprendizado por deposição de idéias, indicando, provavelmente, uma educação autoritária. Pela leitura geral da resposta dada por E023, categorizamos a resposta Q01A-023 como autoritária. Apesar explicitar uma visão de que se aprende com a interação em Q04A-023, o Estudante 023 não caracteriza Como ocorre a interação, não sendo possível a categorizar em uma das zonas de perfil. Tal estudante atenta para o fato de que além de conhecimentos, é possível aprender habilidades. Se as "habilidades" se referem ao saber usar conhecimento, o Estudante 023 está de acordo com o Estudante 025, com o Estudante 026, com o Estudante 028 e com o Estudante 032 em suas respostas à questão Q01A. Indicando que para estes estudantes, ao referir-se à idéia de utilidade do conhecimento, podemos identificar elementos da categoria Para quê?-Por quê?.

Categorizamos a resposta Q04A-026 como dialógica, em particular pelo uso da palavra "analisando", que juntamente com os termos "observando" e "pesquisando", nos remete a uma postura de aprendizado na qual o sujeito atua ativamente.

$\mathrm{Na}$ resposta Q04A-028 identificamos elementos da não-formal, como por exemplo, casa e biblioteca. Nesta resposta é possível reconhecer elementos de outras categorias, fora do foco dado nesta análise da questão. Por exemplo, o uso da palavra "internet", que se relaciona à categoria Quem?/Artefato, indica isso, afinal no contexto dos estudantes, a internet pode, nesse caso, não ser um artefato, mas sim um local (Onde?) em que se pode ensinar fora da escola. 
O Estudante 030, na resposta Q01A-030, procura diferenciar "gravar" de “assimilar". Contudo, não é possível perceber a diferença pelo enunciado. A aquisição de conhecimento parece ser vista pelo Estudante 030 como uma atividade na qual não há preocupação com o que, com quem e como se dá o aprender. Na resposta Q04A-030 identificamos posição ativa do aprendiz por meio das palavras "discussão e debates". Devido à mudança da categorização, consideramos que aprender em um contexto menos fechado, caracterizado pela pergunta Q01A, está associado a uma forma diferente que o aprender em um contexto não-formal, definido pela pergunta Q04A.

Como dissemos anteriormente, na reposta à Q01A, o Estudante 032 relaciona o conhecimento aprendido com seu uso. Em Q04A-032, ele se refere a curiosidade, destacando desta forma, as questões subjetivas do aprendiz. O respondente procura destacar que é a forma como ele mesmo aprende utilizando a palavra "eu". Caracteriza vários artefatos e ainda explicita, por meio de reticências, que há outras formas de aprender. Na questão Q04A o Estudante E032 parece se referir à idéia de um parceiro mais capaz, enfatizando que, para ele, é uma das formas (Como?) de aprender, pois escreve que as "pessoas que dominam outros assuntos melhor do que eu" (Q04A-032), utilizando idéia amplamente discutida na disciplina Elementos e Estratégias para o Ensino de Física ${ }^{36}$.

O Estudante 040, apesar de utilizar poucas palavras, revela aspectos que corroboram uma o uso da zona autoritária de aprender, utilizando a palavra "armazenar" conhecimento. Já em Q04A-040, o Estudante 040 escreve "observando", que não caracteriza a ação e os aspectos individuais de Quem aprende, portanto a resposta foi caracterizada como duvidosa.

\footnotetext{
${ }^{36}$ Como pode ser verificado a partir da ementa da disciplina presente no Apêndice 2.
} 


\subsubsection{Análise das questões “Como se aprende fora da escola?” (Q04A) e "De que forma se colocar na posição do outro ajuda a aprender?” (Q09A)}

As dimensões utilizadas para se construir a pergunta "Como se aprender fora da escola?" (Q04A) foram Como? e O que é?. Enquanto a questão "De que forma se colocar na posição do outro ajuda a aprender?" (Q09A) foi baseada na dimensão Como?/Concepções de Educação/Dialógica e Quem?/Pessoa/Outro.

O nível descritivo obtido no teste qui-quadrado foi 0,0471 , atribuindo às duas questões correlação significante. Na Tabela 25 dispusemos a contagem das respostas em cada categoria para as duas questões.

Tabela 25: Contagem da categorização das respostas das perguntas Q04A e Q09A em Concepções de Educação.

\begin{tabular}{|c|c|c|c|c|c|}
\hline & \multicolumn{5}{|c|}{ 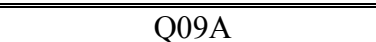 } \\
\hline & & M & $\mathrm{D}$ & A & Total \\
\hline \multirow{4}{*}{$\underset{8}{\stackrel{8}{8}}$} & $\mathrm{M}$ & 0 & 9 & 0 & 9 \\
\hline & $\mathrm{D}$ & 4 & 5 & 0 & 9 \\
\hline & $\mathrm{A}$ & 0 & 2 & 0 & 2 \\
\hline & Total & 4 & 16 & 0 & 20 \\
\hline
\end{tabular}

Legenda: M - Duvidosa; D - Dialógica; A - Autoritária

A questão Q09A foi construída com a intenção de precisar mais o contexto, assim foi utilizada uma categoria de quarta ordem, no caso a Como?/Concepções de Educação/Dialógica. Não identificamos nenhuma resposta categorizada como autoritária e 16 foram categorizadas como dialógicas. Logo, ocorreu o estabelecimento de regras de reconhecimento e realização que privilegiaram a zona de perfil dialógica, como era esperado. A categorização das respostas fornecidas à Q09A indica fortemente que a construção de questões em hierarquias mais baixas leva a delimitação de um contexto que privilegia zonas de perfil conceitual específicas, corroborando a hipótese de uso de zonas de perfil específicas em contextos específicos. 
Cinco estudantes utilizaram a zona dialógica nas duas questões. Deste ponto de vista, os contextos estabelecidos levam mais estudantes a utilizarem a mesma zona de perfil que outros pares analisados anteriormente.

Tabela 26: Seleção de respostas e categorização em Concepções de Educação de Q04A e Q09A

\begin{tabular}{|c|c|c|c|c|}
\hline ES & Q04A - Como se aprende fora da escola? & $\mathrm{C}$ & $\begin{array}{l}\text { Q09A - De que forma se colocar na } \\
\text { posição do outro ajuda a aprender? }\end{array}$ & $\mathrm{C}$ \\
\hline 014 & $\begin{array}{l}\text { Encontrando novos horizontes } \\
\text { estudando-os. }\end{array}$ & M & $\begin{array}{l}\text { Interagindo educador-educando, para se } \\
\text { ver as necessidade um do outro. Além } \\
\text { disso, as dúvidas de um aluno ajudam a } \\
\text { outros. }\end{array}$ & $\mathrm{D}$ \\
\hline 026 & Observando, analisando, pesquisando & $\mathrm{D}$ & $\begin{array}{l}\text { Pq na posição do outro podemos sentir as } \\
\text { suas dificuldades }\end{array}$ & $\mathrm{D}$ \\
\hline 027 & $\begin{array}{l}\text { Com interação de outros indivíduos e } \\
\text { problemas que deve ser resolvidos no } \\
\text { cotidiano. }\end{array}$ & $\mathrm{D}$ & $\begin{array}{l}\text { Sim ao entrar na faculdade possui uma } \\
\text { grande revolta e odiava toda a estrutura, } \\
\text { mas ao colocar me no lugar dos } \\
\text { professores ajudou a compreender o } \\
\text { sistema e viver de forma melhor. }\end{array}$ & M \\
\hline 034 & $\begin{array}{l}\text { Aprender fora da escola observado o meio } \\
\text { e tirando suas conclusões sobre o que se } \\
\text { observa. }\end{array}$ & $\mathrm{D}$ & $\begin{array}{l}\text { Quando colocamos na posição do outro } \\
\text { vemos o mundo de outra forma isso nos } \\
\text { ajuda a ver os pontos os quais não } \\
\text { veriamos apenas pensando da nossa } \\
\text { forma. }\end{array}$ & $\mathrm{D}$ \\
\hline
\end{tabular}

Legenda: ES - Estudante; M - Duvidosa; D - Dialógica; A - Autoritária

Em Q09A-014 percebemos uma visão dialógica de aprender, uma vez que expressa as necessidades do educador e do educando, não se referindo apenas ao aprendiz. O termo “educador-educando" presente em Q09A-014 pode sinalizar a influência significativa de Freire nas visões de educação do Estudante 014, apesar de ter utilizado tal termo, não identificamos em nenhuma outra resposta do estudante uma expressão que pudesse ser extraída diretamente das idéias do autor. O uso do termo também pode ser proveniente das discussões e leituras da disciplina Elementos e Estratégias para o Ensino de Física, uma vez que o texto relativo às Concepções de Educação, escrito por Freire (1987), foi lido e discutido na mesma.

O Estudante 026 em Q09A-026 escreve que se colocar na posição de quem ensina, auxilia a ver as dificuldades deste e de alguma forma isso ajuda a ver como (Como?) se aprende (aprender). 
O Estudante 027 explicita que modificou sua postura frente à educação quando entrou no ensino superior. Segundo ele, o que o levou a fazer isso, foi ter se colocado na posição do professor. A resposta Q09A-027 indica que o estudante percebeu uma mudança na sua posição de aluno para a de professor, indicando uma tendência de confirmar a hipótese de trabalho da quarta pergunta de trabalho. Além disso, o estudante defende que sua vida foi modificada por assumir a papel do outro no aprender.

$\mathrm{Na}$ reposta Q09A-034, identificamos novamente a relação da percepção sensorial com aprender, como nos referimos ao analisar Q09A-008 e Q09A-026. Todos estudantes ao responderem à Q09A referiram-se à perspectiva ou expressões com mesmo sentido. Nestes casos, os estudantes parecem se referir posições possíveis de se assumir nas interações. Neste sentido, podemos considerar que ao mudar a posição os sujeitos mudam as regras de enquadramento, que por sua vez modificam o princípio comunicativo interativo, provocando mudanças no estabelecimento do contexto. Com a mudança do contexto, as regras de realização se modificam, podendo acarretar mudança na zona a ser utilizada em situações semelhantes.

\subsubsection{Análise das questões “Como se aprende?” (Q03A) e "Como se aprende com a televisão na escola?” (Q11A)}

A dimensão utilizada para construir a pergunta “Como se aprende?” (Q03A) foi Como?. Enquanto que a questão “Como se aprende com a televisão na escola?” (Q11A) foi baseada nas categorias Como? e Quem?/Artefato e Onde?/Formal.

O nível descritivo encontrado ao se aplicar o teste qui-quadrado foi $0,0257 . \mathrm{Na}$ Tabela 27 dispusemos a contagem das respostas categorizadas para as duas questões. 
Tabela 27: Contagem das respostas categorizadas às perguntas Q03A e Q11A em Concepções de Educação.

\begin{tabular}{|c|c|c|c|c|c|}
\hline & \multicolumn{5}{|c|}{ Q11A } \\
\hline & & $\mathrm{M}$ & D & A & Total \\
\hline \multirow{4}{*}{ 艿 } & $\mathrm{M}$ & 4 & 1 & 2 & 7 \\
\hline & $\mathrm{D}$ & 9 & 2 & 0 & 11 \\
\hline & $\mathrm{A}$ & 0 & 0 & 2 & 2 \\
\hline & Total & 13 & 3 & 4 & 20 \\
\hline
\end{tabular}

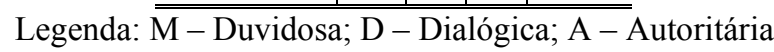

A questão Q03A foi construída em uma hierarquia de segunda ordem, com o objetivo de pouco fechamento de contexto. Enquanto que a questão Q11A teve um foco mais específico de avaliar, como ocorre o uso das zonas com a utilização de um Artefato (Televisão) em um espaço formal.

A categorização é a mesma em 8 respostas. Notamos que um número significativo de respostas foram categorizadas como duvidosas tanto em Q03A, num total de 7, quanto em Q11A, no total de 13. Apesar disto, identificamos uma significativa incidência (7) de categorização duvidosa em Q11A e dialógica em Q03A. Isto indica que a categoria formal e o artefato (presentes na Q11A) não estabelecem regras de reconhecimento e enquadramento tão claras quanto num contexto menos específico (Q03A).

Onze respostas dos estudantes foram categorizadas como dialógicas em Q03A, indicando que a questão remete, mais freqüentemente, os estudantes a utilizarem a elementos da categoria dialógica.

Tabela 28: Seleção de respostas e categorização em Concepções de Educação de Q03A e Q11A

\begin{tabular}{|c|c|c|c|c|}
\hline ES & Q03A - Como se aprende? & $\mathbf{C}$ & $\begin{array}{l}\text { Q11A - Como se aprende com a televisão } \\
\text { na escola? }\end{array}$ & $\mathbf{C}$ \\
\hline 014 & $\begin{array}{l}\text { Aprende-se analisando e raciocinando. Avaliando, } \\
\text { conversando interagindo com o conteúdo, tendo I I } \\
\text { vontade e objetividade. }\end{array}$ & $\mathrm{D}$ & $\begin{array}{l}\text { Através de filmes que podem ser analisados } \\
\text { e discutidos. A TV ajuda a expor o conteúdo } \\
\text { que tenta-se aprender (ensinar). }\end{array}$ & M \\
\hline 027 & $\begin{array}{l}\text { Todo indivíduo aprende frente a um problema, } \\
\text { sem motivação não existe processo de } \\
\text { aprendizagem (minhas palavras) }\end{array}$ & $\mathrm{M}$ & $\begin{array}{l}\text { Usando como instrumento e não meio final. } \\
\text { A televisão deve ser contextualizada e } \\
\text { inserida nas disciplinas. Um exemplo é a } \\
\text { constante onda de violência, a mídia pode } \\
\text { ser usada p/ o trabalho na escola }\end{array}$ & $\mathrm{D}$ \\
\hline
\end{tabular}




\begin{tabular}{|c|c|c|c|c|}
\hline ES & Q03A - Como se aprende? & $\mathbf{C}$ & $\begin{array}{l}\text { Q11A - Como se aprende com a televisão } \\
\text { na escola? }\end{array}$ & $\mathbf{C}$ \\
\hline 028 & Por repetição, reflexão, discussão, construção. & $\mathrm{D}$ & $\begin{array}{l}\text { Por meio de programas educativos que } \\
\text { façam despertar a curiosidade dos mesmos } \\
\text { para o assunto abordado. Associando ciência } \\
\text { c/ a tecnologia moderna. }\end{array}$ & $\mathrm{D}$ \\
\hline 030 & $\begin{array}{l}\text { Através de leituras; reflexões; discurssões; } \\
\text { praticando exercícios e de uma certa forma até } \\
\text { decorando; assistindo documentários; filmes }\end{array}$ & $\mathrm{D}$ & $\begin{array}{l}\text { A televisão é um dos recursos audiovisuais } \\
\text { que permitem o professor trazer à sala de } \\
\text { aula, a física de uma maneira não formal; } \\
\text { por exemplo. Nem toda a TV nos } \\
\text { proporciona as diferentes maneiras de como } \\
\text { o mundo pensa. }\end{array}$ & M \\
\hline 034 & $\begin{array}{l}\text { Se aprende relacionando com outras pessoas } \\
\text { compartilhando os seu conhecimento e ouvindo o } \\
\text { ponto de vista dos outros, ou também se aprende } \\
\text { simplesmente observando o meio ao seu redor. }\end{array}$ & $\mathrm{D}$ & $\begin{array}{l}\text { A televisão pode se usar para passar vídeos } \\
\text { sobre algum assunto de física, ou não, e } \\
\text { depois podemos pedir aos alunos que } \\
\text { exponham o que eles observaram no video } \\
\text { que se relaciona com física, e quais os fatos } \\
\text { que físicamente eles acham que não } \\
\text { acontece. }\end{array}$ & M \\
\hline 039 & $\begin{array}{l}\text { Com práticas, conversar } \quad \text { (interações), } \\
\text { observações, desafios, etc. }\end{array}$ & & $\begin{array}{l}\text { Com informações interessantes, que chame a } \\
\text { atenção e faça com que as informações } \\
\text { fiquem armazenadas. }\end{array}$ & A \\
\hline
\end{tabular}

Legenda: ES - Estudante; M - Duvidosa; D - Dialógica; A - Autoritária

O Estudante 014 destaca, em Q03A-014, que o aprendizado ocorre na interação, além de considerar os aspectos subjetivos de quem (Quem?) aprende. Já em Q11A014, não deixa clara sua posição. A resposta é caracterizada como duvidosa, pois a primeira parte poderia ser enquadrada como dialógica - já que explicita a discussão sobre aprender. Contudo, a segunda parte de Q03A-014 gera dúvidas, pois se refere a "expor" o conteúdo, que seria autoritária, e ao mesmo tempo ao defender uma relação entre ensinar e aprender. Neste sentido, não fica clara a categoria mais adequada.

Em Q03A-027 o estudante refere-se a motivação, mas não é possível identificar elementos que indiquem a categoria utilizada. Porém, nesta resposta, o uso do termo "minhas palavras" indica que queria ressaltar que a idéia era sua e não de outro, indicando também que poderia estar considerando o questionário como uma avaliação da disciplina e não como um instrumento de pesquisa. Dada a possibilidade, analisamos suas respostas a outras questões (e.g. Q23A, Q05A, Q02A, Q19A etc.), e identificamos que o E027 faz uma relação do questionário com o curso. $\mathrm{O}$ estudante chega a se referir ao professor da disciplina, repetindo 
expressões utilizadas tanto pelo docente como pelos colegas durante o curso. Assim, sempre que analisamos as respostas desse estudante levamos em conta que ele está trazendo elementos que são marcadores do contexto estabelecidos na disciplina e não somente relativos às questões apresentadas no questionário.

Apesar de na Q03A-028 encontrarmos uma visão de ensino por repetição consideramos que essa é dialógica devido aos termos "reflexão, discussão, construção" destacados pelo respondente. O Estudante E028 responde à Q11A referindo-se à curiosidade e à relação da ciência com a tecnologia moderna, caracterizou uma visão dialógica, pois a curiosidade é algo de cada pessoa, e não é consenso sempre.

O Estudante 030, na resposta à Q03A, deixa claro que há várias formas de aprender. Ele distingue as diversas formas de aprender (categoria Como?) e seus contextos específicos de uso.

O Estudante E034 também explicita várias formas (categoria Como?) de aprender em Q03A-034, destacando a importância do relacionamento entre as pessoas para o aprendizado. Em Q11A-030 explicita um papel ativo para os estudantes no processo de aprendizagem, contudo o papel do professor é omitido, levando a dificuldades para identificação da categoria utilizada.

Da mesma forma que os Estudantes E030 e E034, o Estudante E039 identifica várias formas de aprender em sua resposta à Q03A. Contudo, na resposta à Q11A-039, privilegia apenas uma forma de aprendizagem ao utilizar o termo "armazenadas", o que nos levou a categorizar a resposta na categoria autoritária. 


\subsubsection{Análise das questões "De quais formas podemos aprender com um colega na escola?” (Q07A) e “Como se aprende com a televisão na escola?” (Q11A)}

As dimensões utilizadas para se construir a pergunta "De quais formas podemos aprender com um colega na escola?" (Q07A) foram Como Quem/Pessoa/Outro e Onde/Formal. Enquanto que a questão “Como se aprende com a televisão na escola?” (Q11A) foi baseada nas categorias Como, Quem/Artefato e Onde/Formal.

O nível descritivo encontrado ao se aplicar o teste qui-quadrado foi 0,0456 , significativo para $\alpha=5 \%$. Na Tabela 29 dispusemos a contagem das categorizações para as respostas destas duas questões.

Tabela 29: Contagem da categorização das respostas das perguntas Q07A e Q11A em Concepções de Educação.

\begin{tabular}{|c|c|c|c|c|c|}
\hline & \multicolumn{5}{|c|}{ Q11A } \\
\hline & & $\mathrm{M}$ & D & A & Total \\
\hline \multirow{4}{*}{$\frac{\mathbb{8}}{8}$} & $M$ & 2 & 0 & 0 & 2 \\
\hline & $\mathrm{D}$ & 11 & 3 & 2 & 16 \\
\hline & $\mathrm{A}$ & 0 & 0 & 2 & 2 \\
\hline & Total & 13 & 3 & 4 & 20 \\
\hline
\end{tabular}

Já discutimos a categorização de Q11A, porém cabe destacar, em relação à questão Q07A, dois dos 13 de indivíduos categorizados em Q11A como duvidosos também foram categorizados como duvidosos na questão Q07A e 11 dos 13 duvidosos em Q011A, foram categorizados como dialógicos em Q07A. Esse é o principal fator que contribuiu para o nível descritivo ser significativo. Percebe-se que a questão Q07A teve um maior número de respostas na categoria dialógica, pois 16 estudantes foram identificados nesta. As duas questões são bastante semelhantes, diferindo apenas pela substituição de "um colega" (Q07A) por "a televisão". Isto é, a mudança ocorre apenas dentro da dimensão Quem?/Pessoa/Outro (Q07A) para Quem?/Artefato/Televisão (Q11A). 
Apesar desta semelhança, a modificação no enunciado provoca mudança significativa nas regras de reconhecimento, e conseqüentemente nas regras de realização, provocando utilizações diferentes das zonas de perfil nos contextos estabelecidos. Portanto, podemos inferir que cada uma das questões define contextos que privilegiam diferentes zonas do perfil conceitual de aprender.

Cabe destacar que as regras de realização influenciam na utilização das zonas de perfil. Estas são construídas a partir dos elementos discursivos dos indivíduos. Contudo, regras de realização semelhantes podem não levar a usos idênticos das zonas de perfil. Isto é, uma pequena diferença no discurso - por exemplo, a substituição de uma palavra como ocorre nas perguntas Q07A e Q11A - pode provocar o estabelecimento de regras de realização correlacionadas, mas pode levar à utilização de zonas de perfil diferentes.

Tabela 30: Categorização das respostas de Q07A e Q11A quanto a Concepções de Educação do Questionário Final

\begin{tabular}{|c|c|c|c|c|}
\hline ES & $\begin{array}{l}\text { Q07A - De quais formas podemos } \\
\text { aprender com um colega na escola? }\end{array}$ & $\mathbf{C}$ & $\begin{array}{l}\text { Q11A - Como se aprende com a televisão } \\
\text { na escola? }\end{array}$ & C \\
\hline 001 & $\begin{array}{l}\text { As vezes o colega aprende a matéria e } \\
\text { passa para outro com palavras mais } \\
\text { próximas dos alunos. }\end{array}$ & $\mathrm{D}$ & $\begin{array}{l}\text { Ela proporciona mais recursos visuais e } \\
\text { auditivos do que uma lousa. }\end{array}$ & M \\
\hline 023 & $\begin{array}{l}\text { Conversando a respeito de um tema, } \\
\text { observando como ela faz as cosias ou } \\
\text { trocando conhecimentos que voce tem e o } \\
\text { outro não. }\end{array}$ & $\mathrm{D}$ & $\begin{array}{l}\text { A televisão pode ser usada para passar } \\
\text { filmes didáticos ou de entretenimento que } \\
\text { podem ser discutidos e associados c/ o } \\
\text { conteúdo, mas não se aprende com a } \\
\text { televisão, e creio na discussão c/ alunos e } \\
\text { prof., assim [******????] um vídeo }\end{array}$ & $\mathrm{D}$ \\
\hline 026 & $\begin{array}{l}\text { Estudando junto e trocando } \\
\text { conhecimentos }\end{array}$ & $\mathrm{D}$ & $\begin{array}{l}\text { A televisão pode ser usada para ilustrar os } \\
\text { conceitos dados }\end{array}$ & A \\
\hline 035 & $\begin{array}{l}\text { Podemos aprender ensinando este colega, } \\
\text { pois isto nos força a refletir sobre o que } \\
\text { estamos ensinando e para termos o } \\
\text { conteúdo que está sendo ensinado de } \\
\text { forma clara na nossa cabeça. Também } \\
\text { aprendemos quando o colega é o "parceiro } \\
\text { mais capaz", que nos auxilia }\end{array}$ & $\mathrm{D}$ & A televisão é uma fonte de informação. & A \\
\hline
\end{tabular}

Legenda: ES - Estudante; M - Duvidosa; D - Dialógica; A - Autoritária

Devido à similaridade das questões Q07A e Q11A, podemos tentar identificar qual a diferença de se aprender com um colega e com um artefato em um espaço formal. Vemos 
que em Q07A-001, o estudante refere-se à linguagem entre quem ensina e quem aprende. Fica implícito o professor como indivíduo distante dos alunos, e em contraponto os alunos têm uma linguagem próxima entre si. Nesta resposta, identificamos elementos dialógicos e a consideração das diferenças individuais, indicando uma preocupação com a comunicação entre os aprendizes e quem ensina. O mesmo Estudante 001, em Q11A-001, refere-se ao artefato apenas por seus atributos práticos, não mencionando quem ensina, não sendo possível, dessa forma, identificar elementos de nenhuma das categorias. Portanto, observamos um padrão de respostas diferente entre as questões.

O Estudante E023, nas respostas às questões Q07A e Q11A, privilegia em seu discurso o papel da comunicação e da interação entre os indivíduos. Caracterizando, em Q11A023, que a televisão por si só não ensina, mas pode ser utilizada pelo professor para apresentar conteúdo (categoria autoritária) e vai se efetivar durante a discussão (categoria dialógica) entre professor e alunos.

Os Estudantes E026 e E035, na Q07A, explicitam a idéia de aprender por meio do "estudar junto" e não apenas à transmissão de conhecimento entre um e outro. Da mesma forma, a categorização na questão Q11A é igual, contudo com categorização como autoritária em Q11A, diferente da dialógica na Q07A. Isto porque para estes respondentes, a televisão é vista apenas na direção de ilustradora ou informativa, não ocorrendo explicitação de Como o artefato televisão é utilizado por quem ensina e por quem aprende. Relacionando a categorização com as respectivas zonas de perfil, podemos interpretar que cada uma das perguntas regras de reconhecimento e realização distintas, levando à utilização de zonas de perfis conceituais diferentes. 


\subsubsection{Análise das questões “O que é aprender?” (Q01A) e “Como se ensina física mal?” (Q19E)}

A dimensão utilizada para se construir a pergunta “O que é aprender?” (Q01A) foi $O$ que é. Enquanto que a questão “Como se ensina física mal?” (Q19E) foi baseada nas categorias $O$ quê, Para quê-Por quê e Como.

O nível descritivo encontrado ao se aplicar o teste qui-quadrado foi de 0,0067 , indicando alta relação para $\alpha=1 \%$. Na Tabela 31 dispusemos a contagem das respostas em cada categoria para as duas questões.

Tabela 31: Contagem da categorização das respostas das perguntas Q01A e Q19E em Concepções de Educação nas questões coincidentes

\begin{tabular}{cc|c|c|c|c}
\hline \hline & \multicolumn{5}{c}{ Q19E } \\
\hline & $\mathrm{M}$ & $\mathrm{D}$ & $\mathrm{A}$ & Total \\
\hline \multirow{\Xi}{\Xi}{$\mathrm{M}$} & 0 & 0 & 1 & 1 \\
\cline { 2 - 6 } & $\mathrm{D}$ & 1 & 0 & 0 & 1 \\
\hline $\mathrm{A}$ & 0 & 0 & 8 & 8 \\
\hline \multicolumn{2}{c}{ Total } & 1 & 0 & 9 & 10 \\
\hline \hline
\end{tabular}

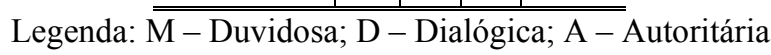

Apesar da quantidade de dados para análise ser pequena, obtivemos um nível descritivo forte, mostrando uma forte correlação entre as categorizações das duas questões. A principal contribuição para a correlação foi que ambas as questões tiveram um número acentuado de respostas categorizadas como autoritárias. Ou seja, nas duas questões, a categoria dialógica praticamente não ocorreu. Pelas respostas dadas a estas questão, é possível evidenciar uma relação entre ensinar e aprender, indicando que devemos assumir a hipótese nula da Pergunta 2 como falsa e a hipótese de trabalho da como verdadeira.

É notável a relação feita pelos estudantes, eles definem o aprender relacionando a como se ensina mal. Aparentemente, isso nos leva a uma contradição entre 
ensinar e aprender, afinal esperamos que ao perguntarmos a um indivíduo sobre como se aprende, que ele responda que é de uma forma que concorda ou considera como sendo boa.

A contradição pode ser entendida como um indicativo da mudança da posição do respondente enquanto aluno e professor. Isto é, quando perguntado sobre "O que é aprender?" (Q01A), se comporta como professor e quando perguntado "O que é ensinar física mal?" (Q19E) se comporta como aluno. Vemos que a delimitação de contexto de cada uma das questões é diferente. Enquanto Q01A encontra-se no primeiro nível hierárquico, Q19E foi construída com base em várias categorias, provocando maior especificação do contexto. Isto é, em uma questão o contexto está completamente aberto e na outra o contexto está muito mais bem delimitado. Contudo, ambas levam ao estabelecimento de regras de realização semelhantes já que as categorizações são correlacionadas, indicando em parte que o contexto geral inferido pelos estudantes ao responder a primeira questão está próximo daquele inferido para responder a segunda questão.

Tabela 32: Categorização das respostas de Q01A e Q19E quanto a Concepções de Educação

\begin{tabular}{|c|c|c|c|c|}
\hline ES & Q01A - O que é aprender? & $\mathbf{C}$ & Q19E - Como se ensina física mal? & $\mathbf{C}$ \\
\hline 002 & $\begin{array}{l}\text { Aprender não é objetivo nem racional; é } \\
\text { subjetivo e emocional. Não é acumular } \\
\text { dados ou conhecimento. É discutir. } \\
\text { Mesmo que não se obtenha respostas. } \\
\text { Aprender é formular perguntas (não } \\
\text { respondê-las). Não creio em Verdade } \\
\text { Absoluta. }\end{array}$ & $\mathrm{D}$ & $\mathrm{Na}$ escola & M \\
\hline 017 & $\begin{array}{l}\text { Obter novos conhecimentos, formar novas } \\
\text { idéias. }\end{array}$ & A & Fazendo os alunos decorarem o conteúdo. & A \\
\hline 021 & $\begin{array}{l}\text { É adquirir conhecimento, será de qualquer } \\
\text { coisa desde o mais simples do mais } \\
\text { complicado, a vida é um aprendizado }\end{array}$ & A & $\begin{array}{l}\text { Quando simplesmente você não se importa } \\
\text { com o aluno sua didática e metodologia é } \\
\text { ruim, fazendo o aluno decorar fórmula, não } \\
\text { ensinando dúvidas }\end{array}$ & A \\
\hline 026 & $\begin{array}{l}\text { Aprender é apreender as informações que } \\
\text { são transmitidas }\end{array}$ & A & $\begin{array}{l}\text { Apenas passando fórmulas, formas de } \\
\text { solução }\end{array}$ & A \\
\hline
\end{tabular}

Legenda: ES - Estudante; M - Duvidosa; D - Dialógica; A - Autoritária

A resposta Q01A-002 já foi analisada anteriormente, apesar disso, ao se analisar esta com vistas à resposta Q19E-002, percebemos uma crítica ao sistema educacional. 
Isso porque, em Q19E-002, ele expressa que na escola (categoria formal) se ensina física mal, e em Q01A-002 explicita o que "não" é aprender, atribuindo a aprendizagem características próprias do aprendiz - subjetivas e emocionais. Ao usar a negativa para expressar sua opinião, fica implícita uma visão oposta que é negada. A idéia implícita é que na escola existe uma "verdade absoluta". Analisando as duas respostas simultaneamente, é possível inferir que Q19E002, categorizada como duvidosa, poderia ser dialógica. Mas como fizemos até o momento, não faz sentido considerar uma coerência direta entre as respostas devido à diversidade de contextos possíveis de serem estabelecidos e a diversidade de zonas de perfil que podem ser evocadas nestes contextos.

Ocorre uma espécie de contradição nas respostas Q01A-017 e Q19E-017, uma vez que em Q19E-017 o respondente critica o “decorar”, isto é, critica a categoria autoritária dos perfis conceituais de ensinar e aprender, que ele mesmo concebe na pergunta Q01A.

Em Q01A-026 (já discutida anteriormente), é possível observar o uso da idéia de recepção de "informações que são transmitidas", concordando com a resposta do estudante E026 à Q19E.

Como as categorizações estão correlacionadas, a utilização das zonas também o são, se a categorização realmente se relaciona com o uso das zonas de perfil conceitual, isto indica que as regras de realização também são relacionadas, uma vez que estas se referem à utilização das zonas. Apesar de relacionadas, neste caso as regras de realização que levem à utilização de zonas diferentes. Essa relação indica a existência do perfil conceitual de ensinaraprender, hierarquicamente superior e mais complexo que englobaria os perfis conceituais de ensinar e de aprender. 


\subsubsection{Análise das questões “Como se aprende fora da escola?” (Q04A) e “Como se ensina física mal?” (Q19E)}

As categorias utilizadas para se construir a pergunta "Como se ensina física mal?” (Q19E) foram O quê, Para quê e Como. A questão “Como se aprende fora da escola?” (Q04A) foi baseada na categoria Onde/Não-formal e na dimensão Como.

O nível descritivo obtido ao se aplicar o teste qui-quadrado foi de 0,0067 , indicando correlação significativa para o nível de significância 1\%. Na Tabela 33 dispusemos a contagem em cada categoria para as duas questões.

Tabela 33: Contagem da categorização das respostas das perguntas Q04A e Q19E em Concepções de Educação.

\begin{tabular}{|c|c|c|c|c|c|}
\hline \multicolumn{6}{|c|}{ Q19E } \\
\hline & & $\mathrm{M}$ & $\mathrm{D}$ & $\mathrm{A}$ & Total \\
\hline \multirow{4}{*}{ 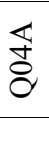 } & $\mathrm{M}$ & 0 & 0 & 6 & 6 \\
\hline & $\mathrm{D}$ & 0 & 0 & 3 & 3 \\
\hline & A & 1 & 0 & 0 & 1 \\
\hline & Total & 1 & 0 & 9 & 10 \\
\hline
\end{tabular}

As respostas da questão Q19E foram categorizadas predominantemente na categoria autoritária, chegando a 9 categorizações. Apenas um estudante teve sua resposta categorizada em duvidosa. Relacionando as categorias com as zonas dos perfis conceituais, isto pode indicar que a Q19E possibilita o estabelecimento de regras de realização que privilegiam a zona autoritária. A grande parte dos estudantes não vê a educação autoritária como uma boa forma de ensino no contexto de aplicação do questionário. Contudo, dois terços desses estudantes, quando perguntados sobre como se aprende fora da escola, assumem uma postura autoritária. Portanto, como no par de questões Q01A e Q19E, há uma contraposição entre a utilização das zonas de ensinar e aprender em contextos comuns. 
Isso indica que cada uma das questões estabelece contextos que privilegiam zonas de perfil distintas para contextos semelhantes. Isto é, os indivíduos possuem várias zonas de perfil conceitual, e estas são utilizadas - mesmo que distintamente - de acordo com o contexto imediatamente estabelecido.

Tabela 34: Categorização das respostas de Q04A e Q19E quanto a Concepções de Educação

\begin{tabular}{|c|c|c|c|c|}
\hline ES & $\begin{array}{l}\text { Q04A - Como se aprende fora da } \\
\text { escola? }\end{array}$ & $\mathbf{C}$ & Q19E - Como se ensina física mal? & $\mathbf{C}$ \\
\hline 026 & Observando, analisando, pesquisando & $\mathrm{D}$ & $\begin{array}{l}\text { Apenas passando fórmulas, formas } \mathrm{de} \\
\text { solução }\end{array}$ & A \\
\hline 032 & $\begin{array}{l}\text { Lendo, observando, sendo curioso, } \\
\text { pesquisando por conta própria, } \\
\text { conversando com pessoas que dominam } \\
\text { outros assuntos melhor do que eu. }\end{array}$ & $\mathrm{D}$ & $\begin{array}{l}\text { Quando se passa muitos conceitos sem que } \\
\text { sejam experimentalmente. É muito melhor } \\
\text { para assimilar um conceito quando se pode } \\
\text { vê-lo acontecer. }\end{array}$ & A \\
\hline 034 & $\begin{array}{l}\text { Aprender fora da escola observado o } \\
\text { meio e tirando suas conclusões sobre o } \\
\text { que se observa. }\end{array}$ & $\mathrm{D}$ & $\begin{array}{l}\text { É não deixar que os outros exponha suas } \\
\text { idéias. }\end{array}$ & A \\
\hline
\end{tabular}

Legenda: ES - Estudante; M - Duvidosa; D - Dialógica; A - Autoritária

Nestas questões selecionamos apenas respostas de três estudantes uma vez que ambas as questões já foram discutidas anteriormente. Todas estas mostraram congruência em categorias distintas categorização das respostas. Uma leitura das duas respostas do Estudante E026, sobretudo pela utilização da palavra "analisando" (Q04A-026), levou a categorização como dialógica. Relacionando a relação entre as categorias e as zonas de perfil conceitual, podemos identificar o privilegio da zona dialógica sobre a autoritária.

O Estudante E032 evidencia a importância da proximidade do aprendiz em relação ao que (O que) ele aprende. Isso fica evidente na segunda parte da resposta Q19E-032, que se refere ao ensinar, quando o estudante contrapõe, à resposta Q04E-032, uma forma "muito melhor" de aprender. As respostas são complementares, ambas mostram a importância das pessoas que interagem na atividade de ensinar-aprender.

Da mesma forma que o Estudante E002, o Estudante E034 evidencia o papel do outro e no ensinar-aprender e a importância da opinião ou ação ativa dos interagentes. 
O nível descritivo mostrou a correlação, contudo a análise qualitativa, com base no enunciado, nos permite verificar que as idéias são complementares em alguns casos. Os três pares de respostas mostram complementação entre as mesmas. Isto mostra que de alguma forma ensinar e aprender, nos contextos estabelecidos, são correlacionadas e complementares indicando a constituição de um perfil conceitual de ensinar-aprender.

\subsubsection{Análise dos pares de questões Q04A-Q05A e Q04E-Q05E}

Não identificamos correlação significativa para $\alpha=5 \%$, entre os pares de questões "Como se aprender fora da escola?" (Q04A) e "Como se aprende na escola?" (Q05A) com nível descritivo 0,0893, e "Como se ensina fora da escola?" (Q04E) e "Como se ensina na escola?" (Q05E) com nível descritivo 0,4314. Se na análise do primeiro par, modificássemos o nível de significância para 9\%, como realizado em algumas pesquisas, passaríamos a ter uma correlação significante. Não fizemos isso implicaria perda de coerência no trabalho, provocando um aumento do erro estatístico. Porém, escolhemos estes pares de questões por considerarmos relevante identificar quais diferenças aparecem na utilização das zonas dos perfis quando modificamos apenas a dimensão Onde.

As questões escolhidas para análise nesta seção têm como objetivo a delimitação de contextos formais e não-formais, devido ao uso das categorias formal e nãoformal. Como argumentamos anteriormente, a delimitação contextual ocorre por meio da utilização de elementos verbais, nos pares de questões analisados, a diferença entre as perguntas de cada par foi "fora da escola" e "na escola". Pretendemos investigar nesta seção a Pergunta de Pesquisa 1. 
Apresentamos a seguir na Tabela 35 e na Tabela 36, de dupla entrada, a contagem da freqüência de categorização das respostas de cada um dos pares de perguntas. Para análise qualitativa dos dois pares de questões construímos a Tabela 37 e a Tabela 38 com algumas respostas a cada uma delas.

Tabela 35: Contagem da categorização das respostas das perguntas Q04A e Q05A em Concepções de Educação

\begin{tabular}{|c|c|c|c|c|c|}
\hline & \multicolumn{5}{|c|}{ Q05A } \\
\hline & & D & A & M & Total \\
\hline \multirow{4}{*}{$\begin{array}{l}\varangle \\
8 \\
8\end{array}$} & D & 6 & 3 & 0 & 9 \\
\hline & A & 0 & 2 & 0 & 2 \\
\hline & $\mathrm{M}$ & 4 & 1 & 4 & 9 \\
\hline & Total & 10 & 6 & 4 & 20 \\
\hline
\end{tabular}

Legenda: M - Duvidosa; D - Dialógica; A - Autoritária
Tabela 36: Contagem da categorização das respostas das perguntas Q01A e Q19E em Concepções de Educação

\begin{tabular}{|c|c|c|c|c|c|}
\hline & \multicolumn{5}{|c|}{$\mathrm{Q} 05 \mathrm{E}$} \\
\hline & & D & $\mathrm{A}$ & $\mathrm{M}$ & Total \\
\hline \multirow{4}{*}{$\stackrel{\text { 任 }}{8}$} & D & 3 & 1 & 3 & 7 \\
\hline & A & 0 & 2 & 1 & 3 \\
\hline & $\mathrm{M}$ & 2 & 3 & 5 & 10 \\
\hline & Total & 5 & 6 & 9 & 20 \\
\hline
\end{tabular}

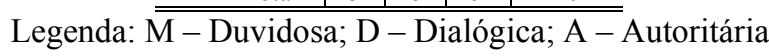

Tabela 37: Exemplos de categorização dos pares de respostas Q04A e Q05A em Concepções de Educação.

\begin{tabular}{|c|c|c|c|}
\hline ES & Q04A - Como se aprende fora da escola? & Ca & Q05A - Como se aprende na escola? \\
\hline 001 & $\begin{array}{l}\text { Observando as situações do cotidiano e não } \\
\text { repetindo os erros. }\end{array}$ & M & $\begin{array}{l}\text { O professor deve perceber como os alunos aprendem e } \\
\text { ensinar dessa maneira. }\end{array}$ \\
\hline 002 & Espontaneamente. & A & $\begin{array}{l}\text { Responderei como é não como acho deveria ser: Com } \\
\text { a suposição do outro no discurso autoritário e } \\
\text { disciplinado e disciplinando. Por não ser natural e } \\
\text { espontâneo, o ensino escolar é pobre e prejudicial. }\end{array}$ \\
\hline 003 & $\begin{array}{llrr}\begin{array}{l}\text { Utilizando o cotidiano de quem } \\
\text { aprendendo, está } \\
\text { conhecimento que já possui. }\end{array} & \\
\text { suas experiências } & \text { e } \\
\end{array}$ & & $\begin{array}{l}\text { Através de experiências, conhecimento prévio e } \\
\text { experiências. }\end{array}$ \\
\hline 005 & Não sei. & $\mathrm{M}$ & Depende! Há quanto tempo não se ensina na escola? \\
\hline 006 & $\begin{array}{l}\text { Depende do assunto, mas, normalmente, dando } \\
\text { exemplos }\end{array}$ & A & $\begin{array}{l}\text { Ensinam-se técnicas de como aprender a escrever a } \\
\text { ler, mas depois cada professor "ensina" de um jeito. }\end{array}$ \\
\hline 004 & Observando & M & Estudando em casa \\
\hline 008 & $\begin{array}{l}\text { Quando nos vemos em situações } \\
\text { desconfortáveis. em conversas com amigos, } \\
\text { pais. }\end{array}$ & $\mathrm{D}$ & A partir da forma como o professor passa o conteúdo. \\
\hline 014 & Encontrando novos horizontes e estudando-os. & M & $\begin{array}{l}\text { Com diálogo, discussão e desenvolvimento de } \\
\text { trabalhos. }\end{array}$ \\
\hline 018 & $\begin{array}{l}\text { Experimentando situações tentando reproduzir } \\
\text { experiências conhecidas. }\end{array}$ & A & $\begin{array}{l}\text { O professor passa sua experiência, influencia no modo } \\
\text { de pensar do aluno }\end{array}$ \\
\hline 023 & $\begin{array}{l}\text { Observando o mundo, lendo e interagindo com } \\
\text { outras pessoas e c/ o mundo. }\end{array}$ & M & $\begin{array}{l}\text { Discutindo com prof. e alunos, assistindo aulas, } \\
\text { fazendo experiências e resolvendo problemas. }\end{array}$ \\
\hline 025 & Vivenciando. & M & $\begin{array}{l}\text { Através da convivência com o professor (quem } \\
\text { conhece mais sobre o assunto) }\end{array}$ \\
\hline 026 & Observando, analisando, pesquisando & $\mathrm{D}$ & $\begin{array}{l}\text { Prestando atenção, discutindo, debatendo e estudando } \\
\text { paca }\end{array}$ \\
\hline 030 & $\begin{array}{l}\text { Através práticas sejam elas voluntárias ou não; } \\
\text { de discussões e debates; através de } \\
\text { documentários; filmes; leituras de livros... }\end{array}$ & $\mathrm{D}$ & $\begin{array}{l}\text { Através de leituras; discussões, debates; aula (até } \\
\text { mesmo expositiva) }\end{array}$ \\
\hline 032 & $\begin{array}{l}\text { Lendo, observando, sendo curioso, pesquisando } \\
\text { por conta própria, conversando com pessoas } \\
\text { que dominam outros assuntos melhor do que } \\
\text { eu. }\end{array}$ & D & $\begin{array}{l}\mathrm{Na} \text { escola se aprende por transferência de } \\
\text { conhecimento, por atividades experimentais, por troca } \\
\text { de saber. }\end{array}$ \\
\hline
\end{tabular}




\begin{tabular}{|c|c|c|c|c|}
\hline ES & QQ04A - Como se aprende fora da escola? & $\mathrm{Ca}$ & Q05A - Como se aprende na escola? & $\overline{\mathrm{Ca}}$ \\
\hline 034 & $\begin{array}{l}\text { Aprender fora da escola observado o meio e } \\
\text { tirando suas conclusões sobre o que se observa. }\end{array}$ & $\mathrm{D}$ & $\begin{array}{l}\text { Na escola se aprende observando, ouvindo o que os } \\
\text { outros dizem e debatendo com eles sobre o que se } \\
\text { observou e seu ponto de vista. }\end{array}$ & $\mathrm{D}$ \\
\hline 035 & $\begin{array}{l}\text { No diálogo com outras pessoas, observando, } \\
\text { ouvindo, sentindo. Refletindo sobre algum } \\
\text { assunto. }\end{array}$ & $\mathrm{D}$ & $\begin{array}{l}\text { De várias formas. Por exemplo durante uma discussão } \\
\text { em grupo ou resolvendo-se exercícios. }\end{array}$ & D \\
\hline 039 & $\begin{array}{l}\text { Com interações com outras pessoas, ouvindo } \\
\text { conselhos, encarando situações de reflexão, } \\
\text { fazendo leituras, assistindo filmes e programas } \\
\text { de TV. }\end{array}$ & $\mathrm{D}$ & $\begin{array}{l}\text { Quando consegui sentir prazer em fazer aquilo, } \\
\text { estudar, trabalhar, entender bem e não esquecer } \\
\text { facilmente. }\end{array}$ & \\
\hline
\end{tabular}

Legenda: ES - Estudante; M - Duvidosa; D - Dialógica; A - Autoritária

\section{$1^{0}$ Par de Análise: Q04A e Q05A}

Estas questões foram colocadas nesta ordem no questionário, pois acreditamos que aprender fora da escola (contexto associado à categoria não-formal) permitiria a utilização de uma gama maior de zonas de perfil do que se apresentássemos de saía o contexto delimitado pela categoria formal. Ao delimitar o contexto em uma questão, poderíamos ter induzido o respondente a manter o contexto anterior em uma questão de situação mais aberta.

Verificamos que das vinte respostas (referentes ao mesmo número de respondentes) da questão Q05A, a metade (10) foi categorizada como dialógica, 6 como autoritárias e apenas 4 como duvidosas. Ao verificarmos o total e a freqüência para a Q04A, percebemos que há significativa mudança na categorização. Nove respostas foram categorizadas como dialógicas, nove como duvidosas e apenas duas como autoritárias. Isto indica que os contextos estabelecidos nas duas questões levam a categorização mais intensa na categoria dialógica, e provavelmente à utilização mais acentuada da zona dialógica.

Entretanto, a questão Q05A estabelece regras de realização que levam a um maior uso da zona autoritária que a questão Q04A. A Tabela 35, criada a partir das categorizações das respostas das duas questões de cada estudante, nos permite verificar como os respondentes utilizam diferentes zonas em diferentes contextos. 
A freqüência de categorização na categoria autoritária foi baixa (2 respondentes), indicando que a zona é mais relevante para a questão Q05A que para a questão Q04A. Isto nos levar a considerar que a questão Q04A estabelece regras de realização que valorizam as categorias duvidosa e dialógica. Portando, aprender fora da escola (categoria nãoformal) está menos focado na transmissão/recepção de conhecimento que em contextos criados pelas marcas fornecidas pela categoria formal.

O Estudante E002, na questão Q04A, responde que se aprende “espontaneamente" fora da escola (categoria não-formal), o espontâneo presume que o processo é independente da relação entre professor e aluno, mas depende apenas das condições adequadas. Na resposta Q05A-002 é possível observar que o estudante em questão sabe que há várias formas de aprender e defende que a escola (categoria formal). Ele destaca que a escola não realiza da melhor maneira possível sua função - ensinar -. Neste sentido, o Estudante E002 destaca as duas zonas de perfil que definimos, e relaciona o ensino escolar à autoritária.

As respostas do Estudante E018 para Q04A e Q05A são categorizadas como Autoritárias, mostrando certa coerência nos contextos estabelecidos pelas categorias formais e não-formais. A transmissão/recepção é evidenciada por "reproduzir" (Q04A-018) e "passa" (Q05A-018), identificamos a falta de consideração em relação ao aprendiz, que simplesmente recebe e reproduz algo, sem crítica.

As respostas do Estudante $026 \mathrm{em}$ Q04A e Q05A foram categorizadas como Dialógicas. Em ambos os casos, o mesmo destaca o papel daquele que aprende como sujeito ativo, que age "analisando" (Q04A-026), “discutindo, debatendo" (Q05A-026). Além disso, é interessante que o termo "pesquisando" (Q041-026), apesar de ser tipicamente escolar, é explicitado como tarefa externa à escola também. Além disso, o Estudante 026 escreve que é necessário um estudo considerável na escola (categoria formal), portanto exigindo atuação ativa 
do aprendiz no processo. O Estudante E034, nas duas questões analisadas, destaca o "ponto de vista" e "debatendo" (Q05A-034) e "tirando suas conclusões" (Q04A-034) qualificando o aprendiz como sujeito ativo no processo de aprendizagem. O Estudante E030 destaca várias formas (dimensão Como) de aprender, dentro e fora da escola, isto é, em contextos definidos pelas categorias formais e não-formais, destacando artefatos comuns "leituras", "debates" e “discussões" nas respostas às duas questões. Apesar de valorizar a discussão (categoria dialógica), qualifica "aula expositiva" como potencial forma de aprender, mesmo que esta presuma o discurso mais informativo e aprendiz menos ativo referente à categoria autoritária.

As respostas do Estudante E025 são exemplos de respostas duvidosas, seja por não serem possíveis se serem categorizadas como dialógicas ou autoritárias. Por exemplo, "vivenciando" (Q04A-025) não fornece elementos suficientes para se inferir sobre como ocorre o processo, quais são as funções de cada interagente etc. Já em Q05A-025, não é possível saber se o "conhece" considera um aprendiz ativo ou passivo, apenas há a explicitação da assimetria do conhecimento. O Estudante E004 responde as duas questões, contudo é demasiadamente sucinto nas sem permitir a identificação de qual categoria seria a mais adequada para a categorização.

\section{$2^{0}$ Par de Análise: Q04E e Q05E}

Verificamos a partir da Tabela 38 que as respostas fornecidas às questões Q04E e Q05E tiveram a categorização mais ostensiva na categoria duvidosa, tanto no total de cada questão (linha e coluna), quanto na categorização em cada célula da tabela. Isto indica que este par de questões leva a uma dúvida mais considerável. Há duas possibilidades possíveis para interpretar a freqüência, ou a questão não contribuiu significativamente para o estabelecimento de contextos de utilização das zonas, ou nos contextos estabelecidos pelas questões, as categorias se misturam, existindo uma amalgama das categorias. Há uma considerável 
distribuição de freqüência por toda a tabela. Isto pode indicar que a primeira interpretação poucas marcas contextuais - é verdadeira, pois o contexto não é estabelecido de forma clara, levando respostas nas diversas categorias.

Além disto, apesar de a questão Q04E levar mais a respostas das categorias dialógica e duvidosa, a questão Q05E remete mais à duvidosa. A coerência entre as respostas das questões 5 mostrou-se mais representativa na categorização duvidosa (5 estudantes).

Tabela 38: Exemplos de categorização dos pares de respostas Q04E e Q05E em Concepções de Educação.

\begin{tabular}{|c|c|c|c|c|}
\hline ES & Q04E - Como se ensina fora da escola? & $\mathbf{C}$ & Q05E - Como se ensina na escola? & $\mathbf{C}$ \\
\hline 009 & $\begin{array}{l}\text { A todo o momento se ensina, através da } \\
\text { vivência e compartilhamento, ou melhor, } \\
\text { troca experiências vividas. }\end{array}$ & & $\begin{array}{l}\text { Não sei. Acho que não há uma única forma de se } \\
\text { ensinar na escola. }\end{array}$ & M \\
\hline 010 & $\begin{array}{l}\text { Exemplos de cidadania; em alguma aula fora } \\
\text { da sala de aula }\end{array}$ & $\mathrm{D}$ & $\begin{array}{l}\text { Através de aulas com professores, lousa }+ \text { giz }+ \\
\text { professor }+ \text { qqr outro recurso didático }\end{array}$ & A \\
\hline 011 & $\begin{array}{l}\text { Para mim todas as formas de ensino são } \\
\text { semelhantes. }\end{array}$ & M & $\begin{array}{l}\text { De acordo com os alunos você adota uma } \\
\text { concepção que se encaixa para facilitar o } \\
\text { entendimento deles, usando uma linguagem } \\
\text { comum. }\end{array}$ & $\mathrm{D}$ \\
\hline 012 & $\begin{array}{l}\text { Com o cotidiano, mas tomando cuidado } \mathrm{p} / \\
\text { não ser inoportuno. }\end{array}$ & $\mathrm{D}$ & $\begin{array}{l}\text { Depende da postura do professor, não existe uma } \\
\text { maneira única. }\end{array}$ & M \\
\hline 015 & Do mesmo jeito que dentro dela. & M & $\begin{array}{l}\text { Não deveria haver diferença entre o ensino na } \\
\text { escola e o ensino fora dela. }\end{array}$ & M \\
\hline 016 & $\begin{array}{l}\text { Sabendo com um conteúdo fechado e } \\
\text { operacional. }\end{array}$ & & $\begin{array}{l}\text { Os elementos para o aprendizado passam pelo giz e } \\
\text { lousa e muitos outros recursos. }\end{array}$ & A \\
\hline 019 & Interagindo & M & $\begin{array}{l}\text { Depende da escola. No entanto, de modo geral um } \\
\text { professor passa sobre o que lhe impõe. }\end{array}$ & A \\
\hline 022 & Ajudando o aluno de ter um espírito critico & $\mathrm{D}$ & $\begin{array}{l}\text { Com respeito mutua, discutindo o conteúdo e } \\
\text { construindo o conhecimento junto. }\end{array}$ & $\mathrm{D}$ \\
\hline 024 & $\begin{array}{l}\text { Da mesma forma que se joga futebol fora do } \\
\text { campo. }\end{array}$ & M & $\begin{array}{l}\text { Com tolerância e respeito das duas partes, docentes } \\
\text { e discentes, com liberdade dada a responsabilidade. }\end{array}$ & $\mathrm{D}$ \\
\hline 031 & $\begin{array}{l}\text { Relacionando o conteúdo escolar com a } \\
\text { realidade. }\end{array}$ & & $\begin{array}{l}\text { O aprendizado pode ocorrer tanto na escola quanto } \\
\text { em qualquer outro lugar, para isso não se tem uma } \\
\text { formula depende do professor e do aluno também }\end{array}$ & $\mathrm{D}$ \\
\hline 033 & $\begin{array}{l}\text { Além dos modos que se pode ensinar com a } \\
\text { TV (estendendo isto para qualquer } \\
\text { observação), também se dá pelo contato, } \\
\text { manipulação. }\end{array}$ & A & $\begin{array}{l}\text { Em que escola? Na qual leciono não vejo ensino } \\
\text { aprendizagem. Quanto a mim tento ensinar como } \\
\text { respondi no 5. [É traduzir toda a "física" que } \\
\text { aprende na faculdade levando-a para a vida dos } \\
\text { alunos. É fazer os alunos ver sob a "ó(p)tica" da } \\
\text { física para que pó [resposta truncada] }\end{array}$ & M \\
\hline 038 & $\begin{array}{l}\text { De várias formas. Às vezes de } \text { modo } \\
\text { sistemático, às vezes nem tanto... }\end{array}$ & & $\begin{array}{l}\text { De muitas formas. Às vezes de modo sistemático, } \\
\text { às vezes nem tanto... }\end{array}$ & M \\
\hline
\end{tabular}

Legenda: ES - Estudante; M - Duvidosa; D - Dialógica; A - Autoritária

O Estudante E016 valoriza o aspecto "operacional" do conhecimento, levantando indícios que o "conteúdo" é "fechado" (Q04E-016). Na resposta Q05E-016, são 
destacados artefatos utilizados e controlados pelo professor na tarefa didática. Portanto, este assume o papel principal no processo e os estudantes - se considerados na interação - assumem papel marginal e pouco significativo no desenvolvimento da atividade.

Em Q05E-016, identificamos certa fuga da resposta, mas ao considerar todos os interagentes na escola, indica que o respondente considera-os atuantes no processo educativo. $\mathrm{Na}$ resposta Q04E-031, o respondente trás a categoria formal para a não-formal, uma vez de diferencia a escola e "a realidade". Neste sentido, os Estudantes E015 e E031 identificam as duas categorias - formal e não-formal. No caso do Estudante E015, apesar de identificar estas categorias, não nos permite identificar uma categoria específica da dimensão concepções de educação.

O Estudante E012 destaca o respeito ao outro tanto em Q04E-012 - com "o não ser inoportuno" - quanto em Q05E-012 - “com postura do professor”.

Observamos, nas respostas Q05E-012, Q04E-015 e Q05E-019, que os respectivos estudantes são capazes de perceber a existência das zonas de perfil e que estas podem ser utilizadas diferentemente num contexto de educação formal. As respostas Q04E-015 e Q04E-019 deixam dúvida quanto à categorização nas categorias autoritária e duvidosa, necessitando complemento, isto é, "interagindo" pode ser ativamente ou passivamente, e o “jeito" vai depender de como ocorre dentro da escola.

$\mathrm{Na}$ resposta Q05E-019, o Estudante E019 identifica que existe elementos externos a relação no texto "modo geral um professor passa sobre o que lhe impõe". Nesta direção, podemos considerar que ele foi capaz de reconhecer macro-contextos em relação à escola. Portanto, a escola define qual das formas de ensinar é adequada aos micro-contextos existentes no macro-contexto que define. Interpretamos tais colocações no sentido de que este 
estudante é capaz de identificar diferentes zonas de perfil e ao mesmo tempo relacionar a utilização destas com contextos.

\section{Comparando os Pares de Análise}

Ao comparar a Tabela 35 e Tabela 36, observamos que os dados referem-se ao segundo par de questões e estão mais distribuídos na Tabela 36 do que na Tabela 35. Uma interpretação possível é que os indivíduos não têm tanta clareza ou posição formada para ensinar quanto tem para aprender independentemente do contexto definidos pelas categorias formal ou não-formal. Neste sentido, os contextos estabelecidos não levam categorias específicas evidenciadas na freqüência tanto das células de cruzamento quanto nos totais, indicando que o ensinar define regras de reconhecimento e realização diferentes do aprender menos específicas, implicando maior incidência da categoria duvidosa. Contudo, percebemos que a diagonal de ambas as tabelas possuem aproximadamente a mesma contagem - doze para Tabela 35 e dez para Tabela 36 -, os conceitos aprender e ensinar levam a mesma categorização. Relacionando categorias e zonas de perfis, isto significa dizer que as regras de realização levam à utilização da mesma categoria. Isto é, considerando as diagonais das duas tabelas, cerca da metade (22) das respostas dos estudantes são categorizadas nas mesmas categorias. Novamente, relacionando as categorias com zonas de perfil, as regras de reconhecimento são correlacionadas em cada um dos contextos de cada par de questões, implicando o uso das mesmas zonas de perfil conceitual.

\subsubsection{Análise dos pares de questões “O que é aprender”-“O que é aprender física?” (Q01A-Q16A) e “O que é ensinar?”-“O que é ensinar física?” (Q01E-Q16E)}

Apesar de não termos identificado correlação significativa para $\alpha=5 \%$, os pares de questões "O que é aprender"-“O que é aprender física?" (Q01A-Q16A) e "O que é 
ensinar?”-“O que é ensinar física?” (Q01E-Q16E), com níveis descritivos 0, 0916 e 0, 2398, respectivamente. O primeiro par, caso modificássemos o nível de significância para $10 \%$, como realizado em algumas pesquisas, seria significante. Contudo, implicaria perda de coerência no trabalho e provocaria um erro consideravelmente maior.

Estes pares foram escolhidos por incluir relacionar a Física (dimensão $O$ que), Ensinar e Aprender. Neste sentido, a definição dos contextos pode mudar com a inclusão do conteúdo, presente na dimensão $O$ quê. Cabe destacar que ao considerar a Física juntamente com os outros conceitos, temos que considerar que existe um perfil conceitual de Física, que provavelmente influência os perfis conceituais de ensinar e aprender física. Neste sentido, há múltiplas relações entre os perfis conceituais complexos estabelecidos. Apesar de considerarmos a existência do perfil conceitual de Física, como não caracterizamos as zonas deste perfil, fizemos a análise considerando apenas a mudança de contexto provocada pela utilização da dimensão $O$ quê.

Tabela 39: Contagem da categorização das respostas das perguntas “O que é aprender?” (Q01A) e “O que é aprender física?” (Q16A) em Concepções de Educação.

\begin{tabular}{|c|c|c|c|c|c|}
\hline & \multicolumn{5}{|c|}{ Q16A } \\
\hline & & A & $\mathrm{M}$ & D & Total \\
\hline \multirow{4}{*}{$\frac{\varangle}{8}$} & A & 1 & 0 & 1 & 2 \\
\hline & M & 0 & 4 & 2 & 6 \\
\hline & $\mathrm{D}$ & 0 & 0 & 2 & 2 \\
\hline & Total & 1 & 4 & 5 & 10 \\
\hline
\end{tabular}

Legenda: M - Duvidosa; D - Dialógica; $\mathrm{S}-$ Autoritária
Tabela 40: Contagem da categorização das respostas das perguntas “O que é ensinar?” (Q01E) e “O que é ensinar física?” (Q16E) em Concepções de Educação.

\begin{tabular}{|c|c|c|c|c|c|}
\hline & \multicolumn{5}{|c|}{ Q16E } \\
\hline & & $\mathrm{A}$ & $\mathrm{M}$ & $\mathrm{D}$ & Total \\
\hline \multirow{4}{*}{$\frac{1}{8}$} & A & 4 & 1 & 0 & 5 \\
\hline & $\mathrm{M}$ & 0 & 0 & 1 & 1 \\
\hline & $\mathrm{D}$ & 2 & 1 & 1 & 4 \\
\hline & Total & 6 & 2 & 2 & 10 \\
\hline
\end{tabular}

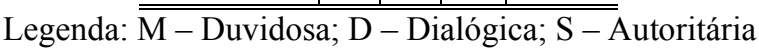

\section{$1^{0}$ Par de Análise: Q01A e Q16A}

Verificamos na Tabela 39 que $70 \%$ da amostra teve suas respostas categorizadas nas mesmas categorias nas questões Q01A e Q16E, indicando que as questões levam ao estabelecimento de contextos que implicam a utilização das mesmas zonas de perfil conceitual. Isto indica que para estes estudantes, aprender Física não difere significativamente de aprender sem um conteúdo específico. Logo, a modificação da categoria $O$ quê não provoca 
modificações nas regras de reconhecimento e enquadramento que levam à utilização das mesmas zonas de perfil conceitual. Aprender física tente a levar a respostas categorizadas nas categorias dialógica e duvidosa e é restrito o caso de aprender autoritariamente. A inclusão do conteúdo específico na questão (Física) implicou uma especificação ainda maior de contexto que leva a respostas na categoria dialógica, considerando mais o indivíduo que no caso menos específico.

Tabela 41: Exemplos de categorização dos pares de respostas Q01A e Q16A em Concepções de Educação.

\begin{tabular}{|c|c|c|}
\hline ES & Q01A - O que é aprender? & Q16A - O que é aprender física? \\
\hline 004 & $\begin{array}{l}\text { Adquirir habilidades para pensar e executar, } \\
\text { independentemente da tarefa a ser A } \\
\text { futuramente executada. }\end{array}$ & Ampliar capacidade de raciocínio \\
\hline 007 & $\begin{array}{l}\text { Aprender é desenvolver uma maneira de } \\
\text { raciocínio que lhe seja útil em qualquer area } \mathrm{M} \\
\text { de sua vida. }\end{array}$ & $\begin{array}{l}\text { Aprender física é buscar formalmente p/ lidar c/ D } \\
\text { tudo que está no nosso redor }\end{array}$ \\
\hline 008 & $\begin{array}{l}\text { Aprender não é somente na escola, estudando } \\
\text { as matérias regulares, o aprendizado se faz } \mathrm{M} \\
\text { desde o momento em que nascemos. }\end{array}$ & $\begin{array}{l}\text { Na minha opinião é relacionar o que acontece na } \\
\text { nossa volta com conceitos já existentes, no caso D } \\
\text { conceitos de física. }\end{array}$ \\
\hline 014 & $\begin{array}{l}\text { Aprender é entender como se realiza tal } \\
\text { acontecimento. É verificar métodos, ler D } \\
\text { (estudar), desenvolver raciocínio sobre. }\end{array}$ & $\begin{array}{l}\text { É entender e visualizar a física. É reconhecer a } \mathrm{D} \\
\text { física no mundo e na nossa realidade. }\end{array}$ \\
\hline 018 & $\begin{array}{l}\text { É conseguir estabelecer ligações entre as } \\
\text { coisas, saber identificar, classificar e D } \\
\text { conhecer, com isso poder utilizar. }\end{array}$ & $\begin{array}{l}\text { Conseguir entender a natureza (fenômenos), e a } \mathrm{D} \\
\text { sociedade através das tecnologias utilizadas. }\end{array}$ \\
\hline 025 & É conseguir utilizar o que foi aprendido. $\quad \mathrm{M}$ & É conseguir explicar os fenomenos. \\
\hline 027 & Transformação, querer crescer, mudar... & Tornar-se físico e possui este "sentimento". \\
\hline 030 & $\begin{array}{l}\text { Aprender é assimilar, áćc adquirir } \\
\text { conhecimentos. Não é gravar. É assimilar e A } \\
\text { acomodar novas informações. }\end{array}$ & $\begin{array}{l}\text { Aprender a física é deixar de viver e ter uma } \\
\text { concepção fragmentada do mundo. É reconhecer; } D \\
\text { entender e associar todos os fenômenos que } \\
\text { ocorrem no nosso dia-a-dia. }\end{array}$ \\
\hline 035 & Não sei. & Eu teria que ter mais tempo para pensar nisso. \\
\hline 039 & $\begin{array}{l}\text { Internalizar informações úteis e conseguir } \\
\text { utilizá-las quando for necessário. }\end{array}$ & Não sei. \\
\hline
\end{tabular}

Legenda: ES - Estudante; M - Duvidosa; D - Dialógica; A - Autoritária

Aprender física, como pode ser verificado em grande parte das respostas, relaciona-se com o cotidiano ou com fenômenos, indicando a utilidade do conhecimento disciplinar. Quanto a aprender sem conteúdo específico relaciona-se apenas com o cotidiano ou com fenômenos para os Estudantes E007 e E039.

Cabe destacar, que apesar do Estudante E039 ser um licenciando em Física, expressa que não sabe o que é aprender física. Porém possui uma idéia para o aprender não 
específico. Neste sentido, podemos dizer que os contextos nos quais a física está presente não há associação a nenhuma zona de perfil conceitual. O Estudante E035, em contraponto, possui uma representação de aprender física, porém não possui uma de aprender. Isto indica, que para este estudante, aprender física é algo diferente de aprender em contextos menos específicos.

\section{$2^{\circ}$ Par de Análise: Q01E e Q16E}

Verificamos na Tabela 40 que $50 \%$ da amostra teve suas respostas categorizadas nas mesmas categorias nas questões Q01E e Q16E. Portanto, há uma significativa diferença entre ensinar e aprender o conteúdo seja específico ou não. Há a predominância das respostas categorizadas como autoritárias (6 respostas). Portanto, a inclusão da dimensão $O$ quê leva ao estabelecimento de regras de reconhecimento e enquadramento que privilegiam a zona autoritária.

Tabela 42: Exemplos de categorização dos pares de respostas Q01E e Q16E em Concepções de Educação.

\begin{tabular}{l|lr|ll}
\hline \hline ES & Q01E - O que é ensinar? & Ca & Q16E - O que é ensinar física? & Ca \\
\hline \hline 006 & $\begin{array}{l}\text { Transmitir, compartilhar conhecimentos. } \\
010\end{array}$ & A & $\begin{array}{l}\text { É além de passar um pouco do nosso } \\
\text { conhecimento, instigar o aluno a se interessar, ter } \\
\text { curiosidade, em entender os fenômenos naturais e } \\
\text { que a Física pode explicar. }\end{array}$ & A \\
\hline 012 & Transmitir conhecimento & A & $\begin{array}{l}\text { É passar a minha paixão pela Física para o aluno, } \\
\text { ou pelo menos tentar. }\end{array}$ & A \\
\hline 015 & $\begin{array}{l}\text { Compartilhar conhecimento. } \\
\text { conteúdo que, posteriormente ele decidirá } \\
\text { nele de acordo com suas convicções e } \\
\text { necessidades. }\end{array}$ & D & $\begin{array}{l}\text { Ensinar a evolução de conceitos sobre a natureza } \\
\text { com o auxilio da matematica. }\end{array}$ & M \\
\hline 019 & $\begin{array}{l}\text { Ajudar no crescimento de alguém. } \\
\text { mostrar um caminho (não "O" caminho). Para se } \\
\text { entender o mundo. }\end{array}$ & A \\
\hline 020 & $\begin{array}{l}\text { Transferir modos diferentes de visão de } \\
\text { mundo. }\end{array}$ & D & $\begin{array}{l}\text { Um "misto" entre ensinar a crescer e Física, e que é } \\
\text { diferente de decoreba. }\end{array}$ & D \\
\hline 022 & $\begin{array}{l}\text { Ajudar a outra aprender fundamentos para } \\
\text { ser melhor pessoa. }\end{array}$ & D & $\begin{array}{l}\text { Passar para o aluno fundamentos da ciência que } \\
\text { pode ajuda-lo viver melhor }\end{array}$ & A \\
\hline 029 & $\begin{array}{l}\text { É dar acompanhamento; suporte; mostrar } \\
\text { onde as informações podem ser encontradas. }\end{array}$ & M & $\begin{array}{l}\text { É ensinar todo formalismo que compreende a } \\
\text { matéria e contextualiza-la no cotidiano do aluno. }\end{array}$ & D \\
\hline $\begin{array}{l}\text { É transmitir para outros qualquer coisa, mas } \\
\text { não é apenas transmitir, o outro tem que } \\
\text { "pegar" algo. Não existe ensinar sem } \\
\text { aprender. }\end{array}$ & A & $\begin{array}{l}\text { É traduzir toda a "física" que aprende na faculdade } \\
\text { levando-a para a vida dos alunos. É fazer os alunos } \\
\text { ver sob a "ó(p)tica" da física para que possam desta } \\
\text { forma ter um modo de explicar o mundo em que } \\
\text { vivem. }\end{array}$ & A \\
\hline
\end{tabular}




\begin{tabular}{l|lr|lc}
\hline \hline ES & Q01E - O que é ensinar? & Ca & Q16E - O que é ensinar física? & Ca \\
\hline \hline 037 & $\begin{array}{l}\text { Com este termo, o ato de ensinar é passar } \\
\text { algum conhecimento ou forma de atuação } \\
\text { para outra pessoa. }\end{array}$ & A & $\begin{array}{l}\text { É passar este conhecimento da civilização para a } \\
\text { pessoa de maneira que ele faça sentido para esta. } \\
\text { Acho importante ensinar também como a ciência } \\
\text { funciona, de maneira geral. }\end{array}$ & A \\
\hline
\end{tabular}

Legenda: ES - Estudante; M - Duvidosa; D - Dialógica; A - Autoritária

Identificamos nas respostas (e.g. Q16E-006 e Q16E-029) - como no outro par analisado - relacionado a aprender e aprende física - que para alguns estudantes, ensinar física também se está ligado à questões contextualizadas com o cotidiano e com fenômenos naturais práticos.

\subsubsection{Análise das freqüências observadas das categorizações das respostas na dimensão a Concepções de Educação}

Não realizamos correlação entre indivíduos diferentes, porém construímos o Gráfico 1, o Gráfico 2 e o Gráfico 3 com a porcentagem das categorizações de cada uma das perguntas na dimensão concepções de educação. Realizaremos a análise, isto é, a comparação entre as categorizações com base na estatística descritiva e considerando a amostra uniforme. Esta consideração pode ser feita visto que encontramos forte correlação entre os modelos de questionário questionários e devido à razoável representatividade do universo de pesquisa nas amostras de cada questionário. Além disto, consideramos representativa a amostra, pois $70 \%$ desta estava no mesmo semestre do curso e por termos distribuído aleatoriamente os subquestionários. 


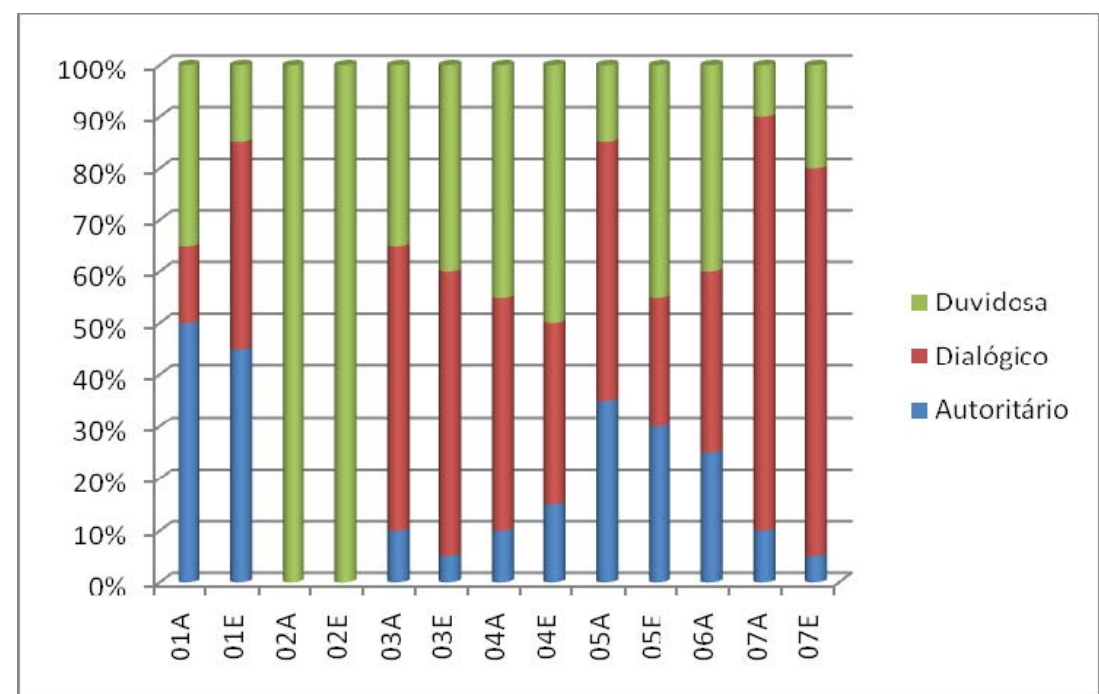

Gráfico 1: Distribuição porcentual das respostas das questões de ensinar e aprender Q01 a Q07 na dimensão Concepções de Educação (amostra 20 estudantes)

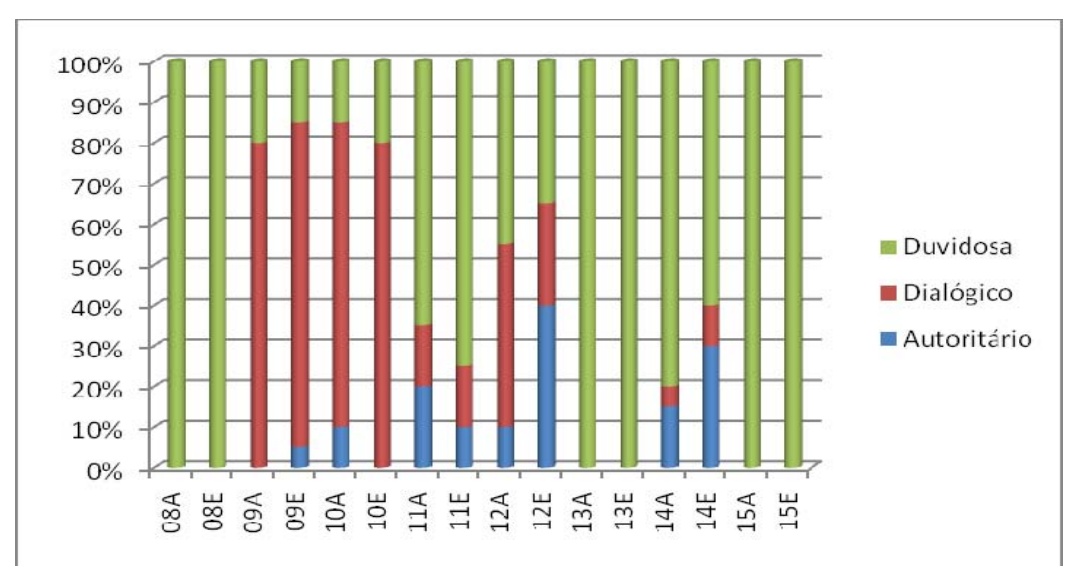

Gráfico 2: Distribuição porcentual das respostas das questões de ensinar e aprender Q08 a Q15 na dimensão Concepções de Educação (amostra 20 estudantes)

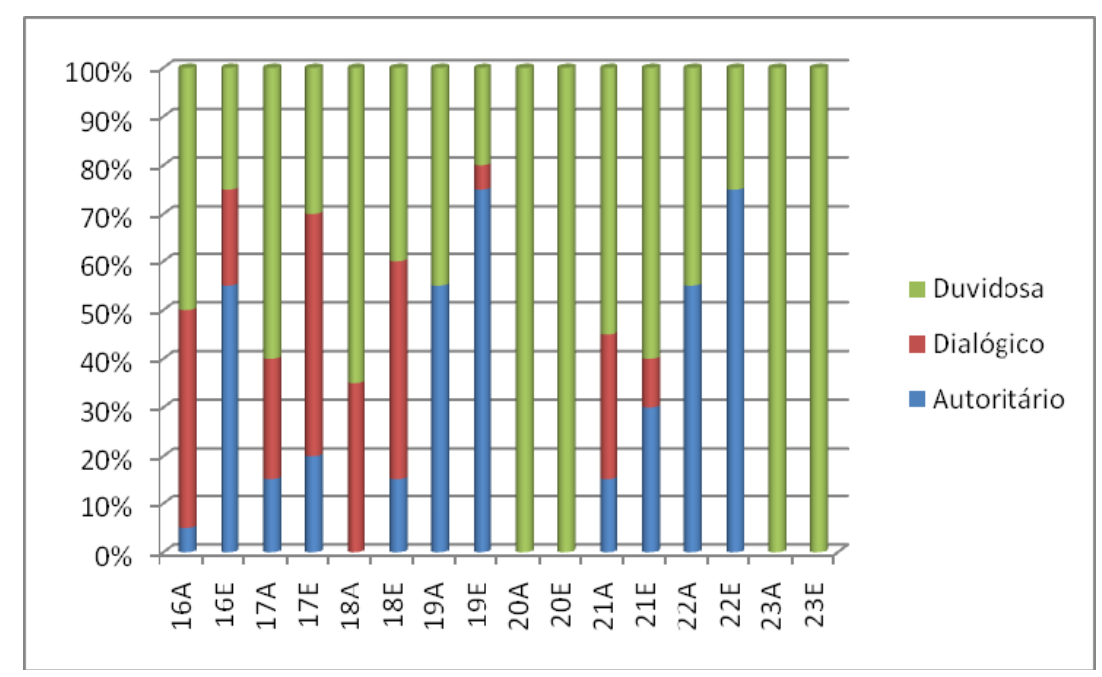

Gráfico 3: Distribuição porcentual das respostas das questões de ensinar e aprender Q16 a Q23 na dimensão Concepções de Educação (amostra 20 estudantes) 
Cabe destacar que as questões Q02A-E, Q08A-E, Q13A-E, Q15A-E, Q20A-E e Q23A-E tiveram todas as respostas categorizadas como duvidosas, pois não traziam elementos suficientes para uma categorização adequada.

Poderíamos discutir sobre todas as freqüências, mas como dissemos, o foco é analisar a relação das perguntas que não puderam ser analisadas pelo método qui-quadrado, portanto analisamos os pares de questões em conjunto.

Com vistas ao método desenvolvido para construção do questionário, consideramos Pergunta de Pesquisa 1 e procuramos verificar a mudança de contextos, identificando questões semelhantes que obtiveram categorizações diferentes. Analisando as freqüências observadas frente à Pergunta de Pesquisa 2, olhando para cada um dos pares de questões com mesma raiz, podemos estudar a relação entre os perfis conceituais de ensinar e de aprender. Em outras palavras, procuramos saber como a base comum das perguntas, sem os conceitos ensinar e aprender, influencia os estudantes a responderem dentro de cada uma das categorias.

Neste sentido, os pares de questões Q03, Q04, Q07, Q09, Q10 e Q11, e tiveram variações pouco significativas nas freqüências de cada uma das categorias. Isto é, as freqüências das respostas observadas de cada categoria foi praticamente constante dentro de cada par de perguntas com mesmo radical. Como as categorizações foram bem próximas, há uma coincidência significativa da categorização de ensinar e aprender. Isto evidencia que, os contextos estabelecidos possuem regras de realização que, provavelmente, provocam o uso das mesmas zonas de perfil conceitual. Neste sentido, mesmo considerando que os respondentes de cada par de questões é diferente, a raiz de cada da questão predomina em relação aos conceitos ensinar e aprender, definindo regras de reconhecimento e realização que privilegiam da mesma 
forma as zonas de perfil conceitual. Isto indica que existe um perfil conceitual complexo (de ensinar-aprender), que engloba os perfis de ensinar e aprender.

Nos pares de questões Q01, Q05, Q12, Q14, Q16, Q17, Q18, Q19, Q21 e Q22, ocorreram modificações significativas na categorização causada pela inserção das palavras ensinar e aprender. Isto indica que os contextos estabelecidos pelas raízes dos pares de questões não levaram, muito provavelmente, à utilização das mesmas zonas de perfil conceitual. No caso, isso mostra que ensinar e aprender, para os contextos estabelecidos, estão desvinculados ou não possuem uma relação direta. Uma interpretação possível é que a relação entre os perfis conceituais de ensinar e aprender é mais complexa e não é explicitada nos contextos estabelecidos apenas pelas raízes das questões.

Apesar de tais interpretações parecerem contraditórias, eram esperadas, uma vez que o perfil conceitual sendo de natureza complexa. Além disto, cada contexto, explicita apenas alguns dos vínculos entre os sub-elementos do perfil conceitual, sejam estes outros perfis conceituais menos complexos ou as zonas deste mesmo perfil conceitual.

Neste sentido, o perfil conceitual de ensinar-aprender é um perfil conceitual de perfis conceituais menos complexos, com diversas hierarquias e múltiplas conexões possíveis entre os elementos (zonas e perfis conceituais menos complexos) do sistema complexo. 


\section{CAPÍTULO 5:}

\section{RESULTADOS}


Apesar de não termos analisado todos os pares de questões que indicaram correlação devido à necessidade de limitação da pesquisa, podemos sintetizar alguns resultados mais gerais obtidos a partir da análise realizada. Os resultados referem-se tanto ao estabelecimento dos perfis conceituais de ensinar, aprender e ensinar-aprender, quanto à validação no instrumento de medida desenvolvido e aplicado nesta pesquisa.

Neste sentido, presumimos verdadeira a hipótese de trabalho primária, que se refere à existência dos perfis conceituais de ensinar e de aprender. Com esta premissa, propusemos as categorias a priori serviram para definição das zonas de perfil e diversos contextos de uso destas. As categorias deveriam contemplar os planos genéticos da teoria histórico-cultural, uma vez que todo conhecimento ocorre segundo estes planos. Neste sentido, procuramos mecanismos de realizar o levantamento destes planos. Para tanto, realizamos um levantamento bibliográfico e a aplicação de um questionário piloto.

O levantamento bibliográfico apresentado no Capítulo 3, delineiam os planos filogenéticos, ontogenéticos e sociogenéticos. Além disto, realizamos um levantamento a partir de pesquisas nas áreas de Educação e Ensino de Ciências, que também contribuíram para o levantamento dos planos ontogenético e sociogenético.

Além disto, para contemplar o plano microgenético, aplicamos um questionário piloto, fornecendo informações sobre a constituição das zonas de perfil de uma amostra similar à amostra de pesquisa, servindo para a definição e a consolidação das categorias existentes até o momento da aplicação deste.

Para corroborar a premissa inicial, partimos da análise do questionário piloto e posteriormente com a análise do questionário. Para tanto, categorizamos as respostas dos estudantes de uma turma da licenciatura em física dadas às diversas questões do questionário, 
identificando a existência, em algumas respostas, de mais uma forma de conceber ensinar e aprender. As categorias autoritária e dialógica permitem a caracterização de zonas tipo “autoritária" e "dialógica", porém foi necessária a introdução de uma terceira categoria duvidosa, que representa, de certo modo, o limite do instrumento de medida. Assim, a categoria duvidosa ou amalgamada, mostra a existência da incerteza na categorização de algumas respostas, que podem vir de uma amalgama entre zonas, quando o estudante não distingue contextos de uso, ou um uma expressão limitada que não dá indícios sobre a discriminação do contexto ao qual pretendíamos remetê-lo. Assim, como resultado geral, identificamos respostas com características da cada uma das zonas de perfil conceitual, além de identificamos algumas respostas categorizadas com mais de uma zona de perfil. Entretanto, não identificamos nenhum estudante que teve todas as suas respostas categorizadas em apenas uma das categorias.

As questões, já a partir da construção, foram agrupadas em quatro modelos de questionários. A partir da análise quantitativa (estatística) e qualitativa dos questionários concluímos que podem ser tratados como equivalentes, uma vez que as correlações entre as categorizações das respostas das partes coincidentes dos diversos modelos de questionários foi alta. Com isto, assumimos que utilização de qualquer um destes, em uma amostra que represente a mesma população, obterá categorizações semelhantes nas respostas. Da mesma forma, com a construção de questionários equivalentes, é possível realizar aplicações, em uma mesma amostra, em dois momentos distintos, identificando uma evolução dos perfis conceituais de ensinar e aprender. Tais aplicações permitirão identificar a influência de intervenções na evolução destes perfis.

Apesar de termos focado a análise na dimensão concepções de educação, em algumas respostas identificamos a menção explícita e implícita de outras categorias. Um exemplo é a dimensão Como/Tipo. 
Fica claro que, as repostas apresentam uma complexidade maior do que uma categoria dá conta de representar. Isso era esperado, uma vez que o esquema da Figura 3 pode ser considerado como um recorte bidimensional na representação do espaço conceitual. $\mathrm{O}$ que não está representado com esse recorte é a complexidade perdida, na qual, todas as categorias possuem relação entre si. Podemos usar o exemplo da utilização do termo "internet" (em Q04A028) que pode se referir tanto a Onde como Quem/Artefato. Ou mesmo como em Q01A-030, em que o Como acaba se referindo a Quem.

Como observamos mudanças na utilização das zonas do perfil, reforçamos a expectativa inicial de que a diferença de elementos discursivos das questões provocaria alteração nos contextos aos quais se referiam. Portanto, somos levados a considerar que diferentes questões do questionário final definiram diferentes contextos de uso das zonas de perfil.

Além das questões definirem contextos, consideramos que os resultados obtidos com as correlações entre alguns dos pares de questões indicam a existência do perfil conceitual de ensinar-aprender. Em alguns casos fomos capazes de identificar a relação entre os perfis conceituais menos complexos, e em outros não. Não identificar a relação direta em todos os pares era um dado esperado, uma vez que os indivíduos, apesar de freqüentarem o mesmo curso de graduação, têm histórias de vidas diferentes e pensam de forma heterogênea sobre vários assuntos. Além do fato de termos assumido a noção de perfil conceitual como uma representação de uma rede complexa de conceitos complexos, isto é, perfis conceituais que se relacionam com outros perfis conceituais em diversas ordens hierárquicas.

Ao construir o questionário foi possível investigar a relação entre algumas das categorias prévias, as questões construídas, as regras de realização e reconhecimento que regem os contextos, as zonas dos perfis conceituais de ensinar e aprender e um perfil conceitual de 
ensinar-aprender. Julgamos que as categorias prévias foram importantes e mesmo determinantes para o estabelecimento das regras de reconhecimento que implicaram o delineamento das regras de enquadramento (que pela sua natureza relacionam-se diretamente com as zonas aqui utilizadas). A investigação da influência destas categorias foi realizada levando-se em conta que algumas palavras que se referiam às categorias foram mais significativas para o estabelecimento de alguns contextos e uso das zonas que outras. Por vezes, a categoria presente na raiz da questão se mostrou mais importante que os conceitos específicos (ensinar e aprender), outras vezes os conceitos foram mais importantes na determinação do contexto. Neste sentido, os resultados indicam que a utilização de várias categorias, simultaneamente, provocam regras de reconhecimento mais específicas, e em conseqüência, contextos mais delimitados.

Observamos ainda, a respeito das categorias prévias, que algumas questões delimitaram os contextos de forma tão extrema que provocaram a utilização quase unânime de determinada zona do perfil conceitual.

As regras de realização se relacionam diretamente com o uso das zonas de perfil, portanto, ao identificarmos diferentes questões com respostas correlacionadas, significa que as regras de realização também são correlacionadas. Estar relacionada não implica ser igual. As regras, quando reconhecidas como iguais, provocam o uso da mesma zona de perfil, contudo podem ser correlacionadas e provocam o uso de diferentes zonas. Isto pode ser verificado, por exemplo, ao se comparar as questões Q07A e Q11A, as quais diferem apenas nas categorias Quem e Onde e tiveram suas respostas com categorizações muito diferentes, mas correlacionadas. Neste sentido, a correlação é entre categorias diferentes. Isto é, quando a resposta de um sujeito é categorizada com o autoritária em uma questão, há uma chance maior da resposta da outra questão ser categorizada como dialógica. Nesse caso, concluímos que cada 
uma das questões privilegia regras de realização correlacionadas, que privilegiam zona do perfil conceitual correlacionadas nestes contextos.

Quanto à relação entre duas perguntas com extremos de contextualização pouca ou muita delimitação contextual -, por exemplo, “O que é aprender?” (Q01A) e "Como se aprender física mal?” (Q19A), pudemos identificar que há uma correlação entre categorizações. As categorias com maior correlação para as duas perguntas foi a autoritária. Entretanto, esperávamos, de certa forma, que ao responder à Q01A o estudante privilegiasse uma forma que considera uma boa forma de aprender. Portanto, ocorreu uma aparente contradição. Já que a forma de aprender mal é igual à forma de aprender. As respostas das questões se mostraram correlacionadas. Neste sentido, as questões definem contextos nos quais os indivíduos não percebem estas contradições. A interpretação que assumimos é que o contexto se modifica de uma questão para outra e que os estudantes utilizam as zonas sem prestar atenção na consistência das respostas. Os estudantes utilizam as zonas de perfil em contextos específicos, mesmo que de forma contraditória, o que indica que possuem mais de uma zona de perfil e que as utilizam, em seu contexto menos específico, como se o "aprender" é "aprender mal”. Apesar da correlação, uma pergunta não influencia a outra no que diz respeito à coerência, ou seja, cada pergunta define seu próprio micro-contexto dentro do macro-contexto do questionário. Assim, o contexto mais específico é mais representativo que o macro-contexto, prevalecendo o contexto mais imediato sobre o mais geral na hora das respostas.

A partir da hipótese de que as questões poderiam delimitar contextos, criamos questões com diversos níveis hierárquicos dentro do esquema representado na Figura 3. Os dados nos permitem dizer que confirmamos a hipótese de que uma questão com várias interligações entre categorias estabelece um contexto específico, privilegiando o uso de determinadas zonas de perfil conceitual. Ocorre alta freqüência da categoria dialógica nas 
respostas às questões Q07A, Q07E, Q10A e Q10E. Nessas questões, as questões foram construídas com a interseção de várias categorias.

Também confirmamos a hipótese de que o contexto é delimitado ao se criar uma pergunta em um nível hierárquico de uma das categorias do esquema de categorias. Isso porque, identificamos o estabelecimento das regras de realização em algumas questões construídas em hierarquia mais baixa de uma das categorias. Na pergunta "De que forma se colocar na posição do outro ajuda a [aprender/ensinar]" (Q09A e Q09E), por exemplo, identificamos uma categorização com alta freqüência na categoria referente ao foco em que foram construídas. Portanto, quanto mais específica a questão, mais privilegiada é uma ou outra categoria. Se assumirmos que as categorias autoritária_e dialógica representam zonas de perfil, as questões Q09A e Q09E, privilegiaram a zona dialógica, uma vez que cada uma foi respondida por 20 estudantes, e cada uma teve 16 respostas categorizadas como dialógicas, isto é, das 40 respostas da raiz das questões Q09, cerca de $80 \%$ dos estudantes utilizaram a zona dialógica. Por isso, podemos dizer que temos fortes indicativos de que a construção de questões, em hierarquias de ordens mais baixas, implica na delimitação de um contexto que privilegia certas zonas.

Ao se conceber um perfil conceitual complexo, as ligações entre alguns conceitos podem não ser diretas, assim, estas não podem ser identificadas explicitamente em todos os contextos. A complexidade do perfil pressupõe que ora os indivíduos utilizem coerentemente as zonas de perfil em determinados contextos, e ora não utilizem coerentemente devido a não identificação do contexto, o que se refere a uma amálgama em um nível hierárquico superior do perfil conceitual. O perfil conceitual complexo de ensinar-aprender fica evidente ao refletirmos sobre os diversos fatores que levam a tantas zonas e características diferentes, representadas pelas categorias provenientes do levantamento bibliográfico acerca dos conceitos ensinar e aprender realizado no Capítulo 3. 
Usando a analogia física para perfil conceitual como um espaço complexo de múltiplas dimensões, podemos dizer que o contexto exerce a função de operador que projeta algumas das dimensões do objeto complexo em um espaço com menor número de dimensões. Esta redução das dimensões do sistema complexo (perfil conceitual) se refere ao uso de zonas dos perfis conceituais dos conceitos menos complexos (ensinar e aprender) relacionadas às zonas do perfil conceitual de ensinar-aprender. Quando não é possível observar a relação, esta pode inexistir ou não ser diretamente observável.

Os resultados obtidos indicam a existência de um perfil conceitual de ensinaraprender mais complexo que os perfis de ensinar e aprender. Além disso, a relação entre os perfis conceituais pode ser coerente, ou seja, zonas equivalentes são utilizadas em questões que levam a contextos similares. Ou pode ser incoerente, o contexto leva a utilização de zonas distintas em cada um dos perfis conceituais menos complexos.

Com a análise das freqüências de categorização dos pares de questões Q01, Q05, Q12, Q16, Q17, Q19 e Q22, pudemos observar que ocorreram modificações significativas na categorização quando alterado o conceito específico (ensinar e aprender) a que se referia a questão. Isso indica que as questões remetiam os diferentes estudantes a diferentes contextos, levando à utilização das distintas categorias e, muito provavelmente, à diferentes zonas de perfil conceitual. Logo, ensinar e aprender, nesses pares de questões, estão aparentemente desvinculados ou possuem uma relação indireta. Isso indica que as ligações entre as zonas de perfil conceitual podem ou não ser diretas, e o que vai provocar a eleição de uma ou outra zona será o contexto.

Algumas respostas de alguns estudantes são categorizados de forma diferente em questões similares que se referem ora a ensinar ora a aprender. O Estudante E027 explicitou 
que modificou sua postura ao entrar no curso de licenciatura, pois passou a ver o aprender na perspectiva de professor e não somente na de aluno. Vários estudantes (e.g. E008, E034 e E026) referiram-se a "perspectiva", "ponto de vista" ou algo similar. Isto pode indicar duas perspectivas, uma de professor, outra de estudante. Apesar dos dados para todos os estudantes não serem tão conclusivos como no caso do E027, uma interpretação possível para os dados obtidos com estes estudantes, é que ao modificar sua posição na interação, implica uma modificação do contexto, ou seja, das regras de realização. Esses casos indicam que a hipótese nula da questão quatro é, muito provavelmente, falsa e que os estudantes modificam sua posição discursiva ao longo do questionário.

Alguns estudantes parecem conseguir identificar diferentes formas de ensinar e aprender, bem como seus diferentes contextos de uso. Isto indica que os estudantes podem discriminar algumas das zonas de perfil e mesmo como algumas são utilizadas em contextos específicos. Por mais de uma vez, identificamos nas respostas críticas a uma zona de perfil conceitual utilizada no contexto de determinada questão, valorizando a oposta.

Uma dimensão que não foi incluída nas categorias a priori, e que é importante para pesquisas futuras, é a dimensão Quando, explicitada pelo Estudante E008 na questão "O que é aprender?”. O estudante se referiu ao vínculo da situação de aprendizado com o tempo. Portanto, o tempo é importante para a utilização das zonas de perfil. Isto fica implícito ao se pensar em evolução do perfil conceitual. Os resultados não permitem a investigação desta categoria, mas torna-se importante na investigação quando se procurar avaliar a evolução destes perfis conceituais.

Algumas categorias que analisamos tiveram destaque ou pareceram influenciar fortemente a utilização das zonas dos perfis conceituais de ensinar e aprender (e.g. Q07A, que 
teve $80 \%$ das respostas categorizadas em dialógica e Q19E, que teve $90 \%$ das respostas categorizadas na categoria autoritária). Quanto à influência de algumas categorias na definição dos contextos, verificamos que aprender sem um contexto específico é diferente do aprender não-formal. Nesta perspectiva, o aprender não-formal tem características próprias, definindo regras de realização também própria, como por exemplo, os pares de questão Q04A-Q05A e Q04E-Q05E, que quando se refere possuem a categoria não-formal têm maior categorização em dialógica e no caso do formal maior incidência da categoria autoritária. A inclusão da categoria não-formal modificou as regras de reconhecimento, acarretando maior especificação do contexto. Por sua vez, a especificação do contexto provocou a mudança das regras de realização, privilegiando o uso de zonas específicas.

Apesar dos pares de questões Q03, Q04, Q07, Q09, Q10 e Q11 - respondentes somente responderem às questões para ensinar ou pra aprender - quando estudados apenas quanto à freqüência das categorizações, possuem regras de realização que levam à aproximadamente a mesma porcentagem do uso de cada zona de perfil conceitual. Neste sentido, a raiz de cada da questão (a parte comum das perguntas) é mais relevante que os conceitos ensinar e aprender, definindo regras de reconhecimento e realização correlacionadas e bem similares, como por exemplo, as questões Q09A e Q09E que tiveram 80\% de categorização na categoria dialógica, independentemente do conceito. As mesmas questões também são exemplos de relação entre as categorizações das respostas, já que na média ocorre a mesma utilização das zonas, indicando a existência do perfil conceitual mais complexo de ensinar-aprender que parece emergir em contextos semelhantes. Além disto, como pode verificado na Tabela 22 há um significativo número de questões com respostas correlacionadas, indicando a relação entre os perfis conceituais de ensinar e de aprender. 
As raízes dos pares de questões Q01, Q05, Q12, Q14, Q16, Q17, Q18, Q19, Q21 e Q22 foram menos importantes que conceito utilizado uma vez que ocorreu significativa modificação na porcentagem de respondentes de cada um dos pares de questões. Portanto, as regras de realização foram mais influenciadas pelas categorias ensinar e aprender que pelas raízes. Neste sentido, nos contextos estabelecidos, ensinar e aprender estão desvinculados ou possuem uma relação indireta, mais complexa, não sendo possível identificá-los diretamente nas respostas.

Os resultados podem parecer incoerentes, mas eram esperados, uma vez que o perfil conceitual é de natureza complexa, sendo que cada contexto, explicita apenas alguns dos vínculos entre os sub-elementos do perfil conceitual. Neste sentido, o perfil conceitual de ensinar-aprender é um perfil conceitual de perfis conceituais "menos complexos", com diversas hierarquias e múltiplas conexões possíveis entre os elementos (zonas e perfis conceituais menos complexos) do sistema complexo.

Ainda referente influência de categorias, identificamos que ensinar mal se relaciona com aprender física. Portanto, há diferenças entre o uso das zonas neste caso, uma vez que poderíamos esperar que os estudantes relacionassem aprender física com as categorias opostas a ensinar mal. O conteúdo Física (dimensão $O$ quê) acarretou regras de realização semelhantes e correlacionadas à ensinar mal, uma vez que ambas as questões tiveram boa parte das respostas categorizadas na categoria autoritária. 
A Física (dimensão $O$ quê) utilizada juntamente com a dimensão aprender, relaciona-se com o "cotidiano" ou com "fenômenos" (e.g. Q16A-018, Q16A-030), indicando a utilidade do conhecimento disciplinar. Quanto à categoria aprender sem conteúdo específico (e.g. Q01A) refere-se apenas com o cotidiano ou com fenômenos para os 20 \% dos estudantes na questão Q01A.

As questões “O que é aprender?” (Q01A) e “O que é aprender física?” (Q16A), que diferem apenas na categoria $O$ quê, estabeleceram regras de realização que acarretaram utilização das mesmas zonas de perfil conceitual. Logo, aprender Física não difere significativamente de aprender sem um conteúdo específico. $\mathrm{Na}$ análise, aprender física remete mais os estudantes a responderem nas categorias dialógica e duvidosa, e é pouco representativo aprender autoritariamente, representando apenas $10 \%$ da amostra. Portanto, a física, na questão Q16A, por remeter mais à categoria dialógica, ocasiona a valorização dos indivíduos que nos contextos definidos pela questão Q01A.

Cerca de $50 \%$ dos estudantes utilizou as mesmas zonas dos perfil de ensinar nas questões “O que é ensinar?" e "O que é ensinar física?". Portanto, há uma significativa diferença entre ensinar e aprender o conteúdo específico e o não-específico. O ensinar levou cerca de $60 \%$ da amostra a utilizar a categoria autoritária. Portanto, a inclusão da dimensão $O$ quê e ensinar causou o estabelecimento de regras de reconhecimento e realização que privilegiaram a zona autoritária. Logo, ensinar física e aprender física acarretam o estabelecimento de regras de realização diferentes, uma vez que as zonas mais utilizadas diferem.

As questões pareadas, colocadas em questionários diferentes, possibilitaram relacionar os questionários, e ao mesmo tempo permitiram comparar ensinar e aprender. Neste 
sentido, como já destacamos, puderam ser comparadas em modelos diferentes de questionários. Contudo, com a opção da organização das questões perdemos alguns elementos importantes relacionados à correlação das questões para um mesmo indivíduo, o que foi possível com as questões pareadas. Neste sentido, a análise indica que seria interessante a inclusão das questões com contextos menos delimitados (e.g. "O que é [aprender/ensinar]?" "Como se [ensina/aprende]?”) em todos os modelos de questionários. Contudo, as incluídas foram suficientes para podermos relacionar a influência de algumas das categorias a priori na definição dos contextos e do uso das zonas de perfil conceitual. Em futuras aplicações dos questionários, validados nesta pesquisa, consideramos importante a inclusão de pares de questões menos específicas. Da mesma forma, poderíamos diminuir ainda mais a extensão do questionário, utilizando apenas as questões que levaram à utilização de várias das zonas de perfil conceitual, ou que se correlacionaram com outras questões.

Identificamos a influência do curso de licenciatura em Física em algumas respostas uma vez que algumas expressões utilizadas foram trabalhadas durante na disciplina Elementos e Estratégias para o Ensino de Física, na qual colhemos os dados. Além das expressões, um dos alunos (E027) refere-se diretamente ao professor várias vezes ao longo do questionário, mostrando interferência da disciplina nas respostas do questionário.

A variação do uso das zonas ao longo do questionário indica que há diversos contextos que modulam as zonas a serem utilizadas. A "incoerência" entre o uso das zonas aponta para comprovação de que o perfil conceitual é elemento complexo que se relaciona com outros perfis. Dessa forma, cada parte (ou par) de questões representa certa projeção do elemento complexo dos perfis conceituais de ensinar e de aprender e mesmo de ensinar-aprender. Ao afirmarmos que algo é relacionado, o é localmente, e não para todo o questionário. A complexidade da análise e as aparentes "incoerências" são reflexo da não linearidade das formas 
de pensar dos indivíduos, que não é simples, e é constituída de uma vasta rede de conceitos relacionados. O privilégio de um elemento ou outro do sistema complexo é feito pelo contexto. Dessa forma, cada agrupamento de questões nos possibilita referir apenas sobre a forma de pensar dos indivíduos nos contextos específicos. 


\section{CAPÍTULO 6: \\ CONSIDERAÇÕES FINAIS}


Neste trabalho, nos propusemos investigar os perfis conceituais de ensinar e de aprender estudantes de uma turma da Licenciatura em Física da USP. Para tanto, consideramos fundamental que os perfis conceituais identificados não se restringissem à caracterização das zonas dos perfis conceituais, mas que fosse levado consideração aspecto que assumimos como essencial para a constituição de perfis conceituais, o contexto. Neste sentido, refletimos sobre a noção de perfil conceitual proposta por Mortimer (1995) e outros conceitos correlacionados, sobretudo contextos e significados segundo Bernstein (1996).

A intenção de realizar o levantamento dos perfis conceituais assumindo os contextos como parte indissociável da noção de perfil conceitual complexo nos levou à construção de um instrumento de pesquisa para o levantamento dos perfis conceituais de ensinar e de aprender. Na fase de elaboração do instrumento de coleta de dados, não identificamos nenhum método, em pesquisas na área de ensino de Ciências, que levasse em conta, desde sua elaboração, os contextos a serem estabelecidos. Por este motivo, nos propusemos o desenvolvimento de um método diferenciado, que possibilitasse o estabelecimento de alguns contextos que incitassem o uso de cada uma das zonas dos perfis conceituais.

Portanto, um dos objetivos principais e o foco da pesquisa, foi a elaboração e a validação de um questionário que contivesse questões que fornecessem elementos textuais para a delimitação de contextos. Desta forma, poderíamos procurar estudar quais as características de um questionário que delimitasse contextos e que contribuiria para se entender a relação entre zonas dos perfis conceituais de aprender e ensinar e esses contextos.

Como não identificamos na literatura nenhuma metodologia para o estabelecimento de contextos, realizamos um levantamento teórico sobre os conceitos. O objetivo do levantamento foi o estabelecimento de categorias que pudessem fornecer elementos 
discursivos que implicassem o estabelecimento de contextos que provocassem a explicitação de zonas de perfil conceitual ligadas a eles. Com o levantamento chegamos a um conjunto de categorias esquematizadas em uma estrutura hierárquica que representa, simplificadamente, as possíveis relações e constituição dos perfis conceituais de ensinar e de aprender.

Criamos uma hipótese, a partir do esquema simplificado, que existe um perfil conceitual de ensinar-aprender mais complexo e que conteria os perfis conceituais de ensinar e aprender. Neste sentido, assumimos a uma visão de perfil conceitual complexo, o qual é constituído de elementos ou sistemas complexos, com múltimas hierarquias e relações, que podem ser identificadas em alguns contextos. Neste sentido, cada zona de perfil conceitual é necessariamente utilizada em um contexto. Em alguns contextos podemos identificar a relação entre perfis conceituais e mesmo a relação entre estes e perfis conceituais hierarquicamente superiores que os englobam. Portanto, a noção de perfil conceitual que assumida é de um sistema complexo, constituído de outros sistemas complexos, que necessariamente tem algumas das suas relações e hierarquias identificadas e estabelecidas em contextos.

Em alguns casos, esperávamos que fosse possível identificar a relação direta entre as zonas de dois ou mais perfis conceituais, em outros, a relação não é direta, pois o contexto estabelecido é menos específico - isto é, está numa hierarquia mais alta - que a relação entre os perfis.

A construção do instrumento de coleta de dados passou pela etapa exploratória com a construção e análise de um questionário piloto, concomitantemente com a pesquisa bibliográfica. O objetivo desta da pesquisa foi a validação de um instrumento que pudesse contribuir para o levantamento das zonas dos perfis conceituais de ensinar e de aprender e a utilização das zonas em contexto. Não tivemos o objetivo de exaurir todas as relações entre os 
perfis como pôde ser verificado pela limitação do número de questões analisadas qualitativamente. Neste sentido, procuramos testar a eficácia do instrumento de pesquisa, o qual apresenta limitações, assim como a análise realizada.

Para reduzir a quantidade de dados e para estudar a relação entre as zonas de perfil, utilizamos como ponto de partida testes estatísticos, os quais mostraram questões com respostas correlacionadas entre si. Contudo, focamos a análise em tabelas de dupla entrada e principalmente na análise qualitativa das respostas. Neste sentido, apesar de termos identificado mais pares de questões correlacionados que os analisados, optamos por limitar a análise aos aqui discutidos, isto é, a primeira metade desses. Esta limitação pela ocorreu extensão do trabalho.

O questionário contou também, com perguntas de cunho axiológico (pares Q18, Q19, Q20 e Q22), contudo não nos aprofundamos na análise por extrapolar os objetivos deste trabalho de mestrado.

A partir do esquema de categorias (Figura 3) construímos perguntas com a finalidade de delimitação contextual de três formas principais. A primeira se referia à utilização simultânea de várias categorias, implicando o aumento no número de elementos discursivos reguladores das regras de reconhecimento de contexto. A segunda forma foi a utilização de categorias de baixa hierarquia que explicitassem regras mais específicas, portanto estabelecendo contextos mais delimitados. A terceira forma foi a utilização de categorias de alta hierarquia, que fornecem poucos elementos discursivos reguladores das regras de reconhecimento, permitindo a menor especificação dos contextos. Esta última forma deveria permitir a manifestação menos específica ou mais "livre" de zonas de perfil conceitual. A criação das questões com base no esquema simplificado teve por objetivo responder a Pergunta de Trabalho 1: "Os enunciados das questões, em um questionário, são capazes de delimitar determinados contextos?”. 
Neste sentido, em algumas questões identificamos a utilização majoritária de uma categoria, que associamos à respectiva zona de perfil, portanto, pudemos concluir que esta questão estabeleceu regras de reconhecimento com base nos princípios comunicativos fornecidos pelos elementos discursivos, que levaram ao estabelecimento de regras de realização que implicaram a utilização desta zona. Além disso, pudemos verificar que algumas questões não privilegiaram mais a utilização de uma ou outra zona dos perfis conceituais. Portanto, estabeleceram regras de reconhecimento menos específicas, que permitiram aos estudantes maior "liberdade" no estabelecimento do contexto. Isto é, regras de reconhecimento menos específicas implicam que os estudantes delimitam contextos mais relacionados com sua vivência e menos relacionados com as idéias dos pesquisadores. Logo, identificamos o estabelecimento de contextos mais específicos e de menos específicos por meio das respostas. Com isto, concluímos que ao menos algumas questões estabeleceram contextos específicos, respondendo afirmativamente a Pergunta de Trabalho 1.

Neste sentido, concluímos que pequenas modificações em uma questão podem levar a mudanças significativas no delineamento do contexto e, portanto na utilização das zonas de perfil conceitual. Em alguns casos a mudança das dimensões ensinar para aprender e viceversa foram mais significativos a parte comum das perguntas (chamadas de raízes), sendo mais importantes na utilização das zonas de perfil. Em outros casos, a raiz, independente das dimensões ensinar e aprender, mostrou-se mais influente na utilização das zonas de perfil conceitual.

Outra pergunta que nos propusemos a investigar, baseada na visão de perfil conceitual complexo, é expressa pelas Perguntas de Trabalho 2 e 3, respectivamente: "Há uma relação entre as zonas dos perfis conceituais de ensinar e aprender?" e "Qual é a relação entre os perfis conceituais de ensinar, de aprender e de ensinar-aprender?". Neste sentido, encontramos 
alguns pares de questões que tiveram correlações entre a utilização das zonas de perfil e outros pares que não encontramos. A interpretação que assumimos é que existe realmente um perfil conceitual complexo de ensinar-aprender que, em alguns contextos, pode revelar a relação entre as zonas dos perfis e em outros não. Como identificamos a relação para alguns contextos, assumimos como verdadeira a existência do perfil complexo, contudo, ora a relação está em um nível hierárquico superior aos contextos estabelecidos, portanto não sendo possível identificar a relação causal.

A Pergunta de Trabalho 4 - "É possível verificar se os licenciandos alternam suas posições de professor e aluno conforme a questão?" - relaciona-se à influência que o curso de licenciatura provoca nos estudantes. Neste sentido, tivemos alguns indicativos pontuais de que ocorre a mudança da posição dos licenciandos. Contudo, a amplitude dos dados e a análise que realizamos não nos permite responder com segurança se ocorre essa mudança. Neste sentido, mostra-se necessário um acompanhamento e uma análise ao longo do curso de licenciatura, o que será feita em oportunidade futura. Portanto, tivemos indicativos, mas não conseguirmos responder a pergunta em questão.

Além de responder três das quatro perguntas de pesquisa, pudemos extrair algumas considerações sobre a inclusão do conteúdo específico Física nas perguntas. Neste sentido, a utilização da dimensão $O$ quê mostrou-se considerável, uma vez que quando esta constava na pergunta, modificou os contextos, provocando respostas caracterizadas em categorias diferentes das mesmas perguntas em hierarquias diferentes. Por exemplo, "O que é ensinar física?" leva a respostas substancialmente diferentes de "O que é ensinar?". Neste sentido, relacionando a categorização com as zonas de perfil, a utilização das zonas foi modificada utilização da dimensão $O$ quê. 
Além disso, ensinar física e aprender física diferiram entre si, indicando a inexistência de vínculo ou a existência em um hierarquia superior, portanto não identificável nos contextos estabelecidos.

Ainda relacionado à dimensão $O$ quê, identificamos uma relação direta entre ensinar mal e aprender física, o que parece ser "incoerente" já que se espera que aprender física deveria se relacionar com o oposto de ensinar mal. Contudo, ao considerarmos a existência do perfil complexo de ensinar-aprender, este fenômeno é compreensível, visto que o conteúdo provoca uma modificação no sistema, causando a reorganização do mesmo, e a utilização de zonas aparentemente incoerentes de acordo com os contextos estabelecidos

Consideramos que o instrumento desenvolvido com base em algumas das categorias prévias, conseguiu atingir o objetivo de revelar a utilização das zonas de perfil em diversos contextos. Ao dividirmos as perguntas em vários modelos de questionários, a redução dos dados foi significativa, contribuindo para a simplificação da categorização e análise de dados, bem como para uma coleta de dados mais consistente que a do questionário piloto. Os questionários mostraram-se equivalentes, podendo ser utilizados em momentos diferentes para avaliar a evolução dos perfis conceituais temporalmente.

A divisão em vários modelos de questionários implicou a limitação das análises individuais dos sujeitos uma vez que um mesmo sujeito não respondeu todas as perguntas. Estes modelos levaram a regras de realização, enquadramento e reconhecimento que regem os contextos, e uso das zonas dos perfis conceituais de ensinar e aprender semelhantes. Contudo, apesar da validação do questionário, este se mostra inviável de ser aplicado nos moldes atuais em amostras maiores por exigir um largo esforço e tempo para categorização e análise. 
Neste sentido, em uma futura aplicação, este deve ser reformulado, reduzindo-se o número de questões ou substituindo algumas por questões fechadas.

A construção de questões que possuem uma base ou raiz comum nos permitiu avaliar se essa raiz ou o conceito envolvido são as responsáveis pela definição das regras de reconhecimento e enquadramento implicando regras de realização que definem o uso de uma ou outra zona do perfil conceitual.

Em etapa de continuidade deste trabalho, procuraremos investigar mais profundamente as questões as relacionadas ao conteúdo e, sobretudo, procurar estabelecer a evolução dos perfis conceituais de ensinar e aprender, ensinar-aprender, ensinar e aprender física. Para tanto, pretendemos reelaborar o questionário, aplicá-lo e realizar o levantamento da evolução dos perfis conceituais de ensinar e aprender e ensinar-aprender, bem como destes perfis conceituais considerando mais efetivamente a dimensão $O$ quê.

A principal conclusão que chegamos é que os perfis conceituais de ensinar e aprender são, sem dúvida, de uma imensa complexidade e constituem outros perfis conceituais, como o de ensinar-aprender, educação, educação científica entre muitos outros. Além do perfil conceitual complexo, outro sistema complexo intrinsecamente relacionado aos diversos perfis conceituais, à comunicação e à linguagem humana, é o que chamamos de contexto. A idéia de contexto complexo - surgida ao final desta pesquisa e não abordada nesta - juntamente com a ampliação da noção de perfil conceitual complexo será abordada na continuação desta pesquisa.

Sem sombra de dúvidas, algumas conclusões e respostas foram possíveis com os recortes realizados nesta pesquisa. Essas podem ser entendidas como pequenas gotas em um vasto rio, constantemente em movimento e evolução. Rio este, que possui diversas vertentes e interconexões complexas e que deve ser estudado aos poucos, em projeções dos sistemas mais 
complexos, isto é, projeções a serem estudadas em pesquisas de mestrado e doutorado. Mais do que conclusões e respostas, encontramos perguntas ainda mais intrigantes acerca do mundo histórico-cultural, isto é, do conhecimento humano existente, tanto formal quanto informal. Neste sentido, esperamos ter contribuído para o entendimento das relações educativas e de um micro-contexto inserido no macro-contexto complexo, ou seja, no mundo socio-históricocultural.

Encerramos a presente pesquisa, da mesma forma que começamos, perguntando:

Como se pesquisa um mundo complexo, delimitador de contextos complexos, sem o conhecimento do mundo complexo? 


\section{REFERÊNCIAS}

\section{BIBLIOGRÁFICAS}


AGUIAR JR., Orlando G. \& MORTIMER, Eduardo F. Tomada de consciência de conflitos: análise da atividade discursiva em uma aula de ciências. Investigação em Ensino de Ciências, 10(2). Disponível em <www.if.ufrgs.br/public/ensino/revista.htm $>$. Acessado em 12/05/2008, 2005.

AMARAL, Edenia Maria Ribeiro \& MORTIMER, Eduardo Fleury Un perfil conceptual para entropía y espontaneidad: una caracterización de las formas de pensar y hablar en el aula de Química Educación Química 15(3), p. 218-233, jul. 2004.

BABBIE, Earl. Métodos de Pesquisa de Survey. (trad. Guilherme Cezario). Belo Horizonte: Ed. UFMG, 2003.

BACHELARD, Gaston. A filosofia do não. Lisboa: Editorial Presença. 1991.

BARBETTA, Pedro Alberto Estatística aplicada às Ciências Sociais $6^{a}$.ed. Florianópolis: Ed. da UFSC, 2006.

BAUMRIND, Diana Effects of Authoritative Parental Control on Child Behavior. Child Development, 37(4), pp. 887-907, 1966.

BAUMRIND, Diana The discipline encounter: contemporary issues. Aggression and Violent Behavior, 2, pp.321-335, 1997.

BAUMRIND, Diana Patterns of Parental Authority and Adolescent Autonomy. New directions for child and adolescent development, 108, summer, 2005

BERNSTEIN, Basil A estruturação do discurso pedagógico: Classe, códigos e controle. (Trad. Tomaz Tadeu da Silva e Luís Fernando Pereira), Petrópolis: Vozes, 1996.

BIANCONI, M. Lucia \& CARUSO, Francisco Educação não-formal. Ciência e Cultura, 57(4), 2005.

BISARD, Walt \& ZEILIK, Michael conceptually centered astronomy with actively engaged students Mercury, 27 (4), pp. 16-19, 1998.

BUNKER, Alison \& KATITJIN, Kurongkurl Conceptions of learning held by Aboriginal entrants to a bridging programme. In HERDSA Annual International Conference, Melbourne, 12-15 July, 1999.

CAMPANARIO, Juan Miguel \& MOYA, Aida Cómo enseñar ciencias?: Principales tendencias y propuestas. Enseñanza de las Ciencias, 17 (2), pp.179-192, 1999.

CARVAlHO, Anna Maria Pessoa \& GIL-PÉREZ, Daniel Formação de professores de ciências, 26, $2^{\underline{a}}$ ed., São Paulo: Cortez Editora, 1995.

CHINN, Clark A. \& BREWER, William F. Theories of Knowledge Acquisition In FASER, Barry J. \& TOBIN, Kenneth G. International Handbook of Science Education Boston: Kluwer Academic Publishers, pp.97-113, 2003.

COUTINHO Francisco Angelo EL-HANI; Charbel \& MORTIMER, Eduardo Fleury Utilizando situações-problema para acessar a tomada de consciência do perfil conceitual: um estudo com a ontodefinição de vida. In Atas do V ENPEC, Bauru: ABRAPEC, 2005.

COUTINHO, Francisdo Angelo Construção de um perfil conceitual de vida. Belo Horizonte: Faculdade de Educação da UFMG. (Tese de Doutorado), 2005. 
COUTINHO, Maria Tereza da Cunha \& MOREIRA, Mercia Psicologia da Educação: Um estudo dos Processos Psicológicos de Desenvolvimento e Aprendizagem Humanos, Voltado para a Educação, Ênfase nas Abordagens Interacionistas do Psiquismo Humano. Belo Horizonte: Lê, 2001.

CUNHA, Maria Bernadete Perfil conceitual: trabalhando concepção de matéria e estados físicos dos materiais com alunos e alunas do ensino médio. Dissertação de mestrado. UFBA/UEFS. Salvador, 2003.

DAVIS, Cláudia \& OLIVEIRA, Zilma de Psicologia na Educação. Coleção Magistério, Série Formação do Professor, 2 ${ }^{\text {a }}$ Ed. São Paulo: Cortez, 1994.

DICIONÁRIO Cambridge. Disponível em: < http://dictionary.cambridge.org > Acesso em: 12 maio de 2008.

DICIONÁRIO Chambers Reference Online. Disponível em: $<$ http://www.chambersharrap.co.uk/chambers/learning/index.shtml $>$ Acesso em: 12 maio de 2008 .

DICIONÁRIO Eletrônico Houaiss da Língua Portuguesa 2.0a.CD-ROM, 2007.

DICIONÁRIO Longman Dictionary of Contemporary English Online. Disponível em < http://www.ldoceonline.com/> Acesso em: 12 maio de 2008.

DREYFUS, Amos; JUNGWIRTH, Ehud \& ELIOVITCH, Ronit Applying the "cognitive conflict" strategy for conceptual change some implications, difficulties and problems. Science Education, 74(5), p. 555-569, 1990.

DRIVER, Rosalind \& EASLEY, Jack. Pupils and paradigms: a review of literature related to concept development in adolescent science students. Studies Science Education, 5, p.61-84, 1978.

DUARTE, António M. Conceptions of Learning and approaches to learning in Portuguese students. Higher Education, 54(6), pp.781-194, dez, 2007.

DUIT, Reinders Conceptual Change Approaches in Science Eduction In SCHONTZ, Wolfgng; VOSNIADOU, Stella \& CARRETERO, Mario New Perspectives on Conceptual Change. New York: Pergamon, 1999.

DUIT, Reindres \& TREAGUST, David. F. Learning in Science - From Behaviorism Towards Social Constructivism and Beyond In FASER, Barry J. \& TOBIN, Kenneth G. International Handbook of Science Education Boston: Kluwer Academic Publishers, pp.3-26, 2003a.

DUIT, Reindres, TREAGUST, David. F. Conceptual change: a powerful framework for improving science teaching and learning. International Journal of Science Education, v.25(3), pp.671-688, 2003b.

EDWARDS, Derek \& MERCER, Neil Common Knowledge: The developmente of understanding in classroom. London e New York: Routledge, 1987.

ENTWISTLE, Noel J., PETERSON, Elizabeth R. Conceptions of learning and knowledge in higher education: Relationships with study behavior and influences of learning environments. International Journal of Educational Research 41 pp. 407-428, 2004. 
FIEDLER-FERRARA, Nelson \& MATTOS, Cristiano Rodrigues Seleção e organização de conteúdos escolares: recortes na pandisciplinaridade. In: Anais do VIII Encontro de Pesquisa em Ensino de Física, Águas de Lindóia, 2002.

FODOR, Jerry Having Concepts: a Brief Refutation of the Twentieth Century. Mind \& Language, 19(1), pp. 57-69, 2004.

FREIRE, Paulo Pedagogia do oprimido. São Paulo: Paz e Terra, 1987

GADOTTI, Moacir A Questão da Educação Formal/Não-formal. In Droit à l'éducation: solution à tous les problèmes ou problème sans solution? Institut International des droits de l'enfant, Sion, 2005.

GARCÍA. J.E Hacia uma teoria alternativa sobre los contenidos escolares. Sevilha: Díada, 1998.

GASPAR, Alberto. ; MATTOS, Cristiano Rodrigues El concepto de impenetrabilidad: de la ciencia producida a la ciencia transmitida. Enseñanza de las Ciencias, v. extra, p. 189$190,2002$.

GASPAR. Alberto Tendências atuais no ensino de física. In Atas do XXIII Encontro de Físicos do norte e Nordeste, Natal, 2005.

GILBERT, John .K.; WATTS, D. Michael. \& OSBORN, Roger .J. Student's conceptions of ideas in mechanics. Physics Educations, 17, 1982.

GREF Física 3: Eletromagnetismo. São Paulo: EDUSP, 1993.

HAHN, Ulrike \& CHATER, Nick Concepts and Similarity In LAMBERTS, Koen \& SHANKS, Davida (Eds.) Knowledge, concepts, and categories. Massachusetts: MIT Press, 1997

HAKE, Richard R. Interactive engagement versus traditional methods: A six-thousand student survey of mechanics test data for introductory physics courses. American Journal of Physics, 66 (1), pp. 64-74, 1998.

HEIT, Evan Knowledge And Concept Learning In LAMBERTS, Koen \& SHANKS, Davida (Eds.) Knowledge, concepts, and categories. Massachusetts: MIT Press, pp. 7-41, 1997

HESTENES, David \& WELLS, Malcolm A mechanics baseline test The Physics Teacher, 30, pp. 159-166, 1992.

HESTENES, David, WELLS, Malcolm \& SWACKHAMER, Gregg Force Concept Inventory Physics Teacher, 30 (3), pp. 141-151, 1992.

HEWSON, P.W. A conceptual change approach to learning science. European Journal of Science Education, 3(4), 1981.

HEWSON, Peter W. \& THORLEY, Richard N. The conditions of conceptual change in the classroom. International Journal of Science Education, 11(5), 1989.

HEWSON, Peter W.; BEETH, Michael E. \& THORLEY, Richard N. Teaching for Conceptual Change In FASER, Barry J. \& TOBIN, Kenneth G. International Handbook of Science Education Boston: Kluwer Academic Publishers, pp.169-182, 2003.

HIRST, Paul H. What is Teaching? (Trad. Para o português de Olga Pombo) Journal of Curriculum Studies, 3(1), pp. 5-18, 1971

HOUAISS, 2001 Dicionário Eletrônico Houaiss, Versão 1.0, Ed. Objetiva, 2001 
KARAM, Ricardo Avelar Sotomaior; COIMBRA, Débora. \& CRUZ, Sonia Maria Silva Correa de Souza Ampliando o conceito de tempo através da inserção da teoria da Relatividade Restrita no Ensino Médio. In Atas do V ENPEC, Bauru: ABRAPEC, 2005.

KARAM, Ricardo Avelar Sotomaior; CRUZ, Sonia Maria Silva Correa de Souza \& COIMBRA, Débora Tempo relativístico no início do Ensino Médio Revista Brasileira de Ensino de Física, v. 28, n. 3, p. 373-386, 2006.

KUBO, Olga Mitsue \& BOTOMÉ, Sílvio Paulo Ensino-aprendizagem: uma interação entre dois processos comportamentais InterAção, 5, pp.133-171, 2001.

KUHN, Thomas Structure of scientific revolutions. $2^{\text {nd }}$ edition, Chicago: University of Chicago Press., 1970.

LA TAILlE, Ives; OLIVEIRA, Marta Kohl \& DANTAS, Heloysa Piaget, Vygotsky,Wallon: Teorias Psicogenéticas em Discussão. São Paulo: Summus, 1992.

LANGUI, Rodolfo. Idéias de Senso Comum em Astronomia In Atas do Encontro Nacional de Astronomia, 2004

LEMKE, Jay 1. Investigar para el futuro de la educación científica: nuevas formas de aprender nuevas formas de vivir. Enseñanza de las Ciencias, 24(1), pp. 5-12, 2006

LEONTIEV, Alexei, O desenvolvimento do psiquismo. Lisboa: Livros Horizonte, 1978.

LIGHTMAN, Alan \& SADLER, Philip Teacher predictions versus actual student gains. Physics Teacher, 31 (3), pp. 162-167, 1993.

LOMÔNACO, José Fernando Bitencourt Princípios Báisicos de Aprendizagem: Modelo Behavorista. In WITTER, 1975.

LOMÔNACO, José Fernando Bitencourt; NUNES, Sylvia da Silveira \& SANO, Walter Tsuyosh Concepções de cegueira de estudantes de um curso de psicologia. Boletim de Psicologia, Vol. LIV, № 120, 2004

LOMÔNACO, José Fernando Bittencourt; PAULA, Fräulien Vidial de; MELLO, Cláudia Berlin de \& ALMEIDA, Fabiane de Amorim Desenvolvimento de Conceitos: O Paradigma das Transformações Psicologia: Teoria e Prática, 17(2), pp.161-168 mai-ago 2001.

LOTMAN, Yuri M. Text within a text. Soviet Psychology, 26(3), pp. 32-51, 1988.

LOWYCK, Joost; ELEN, Jan; CLAREBOUT, Geraldine Instructional conceptions: Analysis froman instructional design perspective. International Journal of Educational Research 41 pp. 429-444, 2004.

MARANDINO, Martha Transposição ou recontextualização? Sobre a produção de saberes na educação em museus de ciências. Revista Brasileira de Educação, 26, 2004.

MARTON, Ference; DALL'ALBA, Gloria \& BEATY, Elizabeth. Conceptions of learning. International Journal of Educational Research, 19 pp.,277-300, 1993.

MARTON, Ference; WATKINS, David \& TANG, Catherine Discontinuities and Continuities in the Experience of Learning: An Interview Study of High-School Students in Hong Kong. Learning and Instruction, 7(1), pp.21-48 1997. 
MATTOS, Cristiano Rodrigues; DALRI, Jackelini \& RODRIGUES, André Machado . Internalization and activity: learning as complex system dynamic. In: Insternational Society foe Cultural and Activity Research Congress, 2008, San Diego. ISCAR 2008 Book of Abstracts. San Diego : UCSD University, v. 1. p. 126., 2008.

MATTOS, Cristiano Rodrigues \& RODRIGUES, André Machado . Theoretical Consideration about conceptual profile dynamic. In: European Science Education Research Association Conference, 2007, Malmö. Proceedings European Science Education Research Association Conference. Malmö : Mlamö University, v. 1. p. 1-12. 2007.

MATTOS, Cristiano Rodrigues \& VIGGIANO, Esdras An instrument for assessement of the conceptual profiles of "to teach" and "to learn". In: GIREP/EPEC Conference on Frontiers of Physics Education, 2007, Opatija. Book of Abstracts/GIREP-EPEC Conference on Frontiers of Physics Education. Rijeka : Filozofski Fakultet Sveucilista, 2007. v. 1. p. 79-80.

MENDES, Francisco; MATTOS \& Cristiano Rodrigues $\mathbf{O}$ uso de intertextos como ferramenta de análise de dados em pesquisa em educação. In: V Encontro Nacional de Pesquisa em Educação em Ciências, 2005, Bauru. Anais V Encontro de Pesquisa em Ensino de Ciências. Bauru: Abrapec, 2005.

MEYER, J. H. F., \& BOULTON-LEWIS, G. M. Variations in students' conceptions of learning: An exploration of cultural and discipline effects. HERDSA Annual Conference. Learning and teaching in higher education: Advancing international perspectives, Adelaide, 1997.

MOORE, Sofia A. Theoretical and Practical Perspectivs on Vygotsky's concept of the Zone of Proximal Development. Tese de Doutorado em Educação, Departamento de Curriculum and Instruction, Illinois State Univesity, 2004.

MOREIRA, Marco Antônio Teorias de Aprendizagem. São Paulo: EPU, 1999.

MORTIMER, Eduardo F \& SCOTT, Phil Atividade discursiva nas salas de aula de ciências: uma ferramenta sociocultural para analisar e planejar o ensino. Investigação em Ensino de Ciências, 7(3). Disponível em <www.if.ufrgs.br/public/ensino/revista.htm>. Acesso 12/05/2008, 2002.

MORTIMER, Eduardo Fleury \& MACHADO, Andréa Horta Múltiplos olhares sobre um episódio de ensino: "Por que o gelo flutua na água?". In Anais do Encontro sobre Teoria e Pesquisa em Ensino de Ciências - Linguagem, Cultura e Cognição; reflexões para o ensino de ciências. Belo Horizonte: Faculdade de Educação da UFMG, 1997.

MORTIMER, Eduardo Fleury .\& SCOTT, Phill.H. Meaning Making in Secondary Science Classrooms. Maidenhead/Philadelphia, Open University Press (2003)

MORTIMER, Eduardo Fleury Conceptual Change or Conceptual Profile Change? Science \& Education, vol. 4 (3), pp. 265-287, 1995.

MORTIMER, Eduardo Fleury Construtivismo, Mudança Conceitual e Ensino de Ciências: para onde vamos? Investigação em Ensino de Ciências, 1(1). Disponível em <www.if.ufrgs.br/public/ ensino/revista.htm>. Acesso 13/04/2005, 1996.

MORTIMER, Eduardo Fleury Linguagem e Formação de Conceitos no Ensino de Ciências, Belo Horizonte: Editora UFMG, 2000. 
MUIJS, Daniel Doing Quantitative Research in Education with SPSS. London: SAGE Publictions, 2006.

MURPHY, G.L. \& MEDIN, D.L. The role of theories in conceptual coherence. Psychological Review 92, p. 289-316, 1985.

ODOM, Arthur Louis. \& BARROW, Lloyd. H. Development and application of a two-tier diagnostic test measuring college biology students' understanding of diffusion and osmosis after a course of instruction. Journal of Research in Science Teaching, 32 (1) pp. 45-61, 1995.

OLA, Halldén Conceptual Change and Contextualization In SCHONTZ, Wolfgng; VOSNIADOU, Stella \& CARRETERO, Mario New Perspectives on Conceptual Change. New York: Pergamon, 1999.

OLIVA MARTÍNEZ, J.M. Algunas reflexiones sobre lãs concepciones alternativas y cambio conceptual. Enseñanza de las Ciencias, 17(1), pp. 93-107 (1999)

OLIVEIRA, Marta Kohl Vygotsky e o processo de Formação de Conceitos. In: LA TAILLE et al., 1992.

PACCA, Jesuína Lopes de Almeida Um perfil dos candidatos ao vestibular da FUVEST (O exame de física e a identificação das estruturas de raciocínio). Tese de doutoramento USP, São Paulo, 1983.

PASSMORE, John The Concept of Teaching The Philosophy of Teaching London: Duckworth, pp. 19-33, 1980.

PEACOCKE, Christopher Interrelations: Concepts, Knowledge, Reference and Structure Mind \& Language, 19(1), pp. 85-98, 2004.

PEDUZZI, Luiz O.Q.; MOREIRA, Marco Antônio \& ZYLBERSZTAJN, Arden As concepções espontâneas, a resolução de problemas e a história da ciência numa seqüência de conteúdos em mecânica: o referencial teórico e receptividade de estudantes universitários à abordagem histórica da relação força e movimento. Revista Brasileira Ensino Física, 14(4), pp. 239-246, 1992.

PERRENOUD, Philippe. Dez Novas Competências para Ensinar. (Trad. Patrícia Ramos) Porto Alegre: Artes Médicas Sul, 2000.

PINO, Angel Ensinar-aprender em situação escolar: perspectiva histórico-cultural. World Wide Web, disponível em www.lite.fae.unicamp.br/sapiens/ensinar.htm, acessado em 5/4/2006, 2006

PINO, Angel $O$ conceito de mediação semiótica em Vygotsky e seu papel na explicação do psiquismo humano. Caderno CEDES, 24, 1990.

PORLÁN, Ariza R., RIVERO, García A.;POZO, R Martín Del. Conocimiento profesional y epistemolog a de los profesores I: Teoría, Métodos e Instrumentos Enseñanza de las Ciencias, 15 (2), pp.155-171, 1997.

PORLÁN, Ariza R.; RIVERO, García A. \& POZO, R Martín Del. Conocimiento profesional y epistemología de los profesores II: Estudios Empíricos y Conclusiones Enseñanza de las Ciencias, 16 (2), pp.271-288, 1998. 
POSNER, George J., STRIKE, Kenneth A., HEWSON, Peter.W. \& GERTZOG, William A. Accommodation of a scientific conception: toward a theory of conceptual change. Science Education, 66(2) p.211-227, 1982.

PRINZ, Jesse \& CLARK, Andy Putting Concepts to Work: Some Thoughts for the Twentyfirst Century Mind \& Language, 19(1), pp. 57-69, 2004.

PURDIE, Nola, \& HATTIE, John Assessing students' conceptions of learning. Australian Journal of Educational and Developmental Psychology, 2, pp. 17-32, 2002.

RADÉ, Tane da Silva \& SANTOS, Renato Pires dos Uma proposta de perfil conceitual para o conceito de força. In V Encontro de Pesquisa em Ensino de Ciências, Bauru: ABRAPEC, 2005.

RIBEIRO, Renata Divulgação Científica e Ensino de Física: Intensões, Funções e Vertentes. Dissertação de Mestrado em Ensino de Ciências (Física) na USP, São Paulo, 2007.

RODRIGUES, André Machado ; MATTOS, Cristiano Rodrigues de Reflexões sobre a noção de significado em contexto. Indivisa, Boletín de Estudios e Investigación (7) p.323-31, 2007.

RUSSELL, Arlete A. A rationally designed general chemistry diagnostic test. Journal of Chemical Education, 71 (4), pp. 314-317, 1994.

SÄLJÖ, R. Learning about learning. Higher Education, 8, pp.443-451, 1979.

SANTOS, Renato Pires dos \& CARBÓ, Antônio Doménech. Uma proposta de perfil conceitual para o conceito de massa. IX Encontro de Pesquisa em Ensino de Física, Jaboticatubas: SBF, 2004

SCOTT, Phil; MORTIMER, Eduardo F. \& AGUIAR JR., Orlando G. The Tension Between Authoritative and Dialogic Discourse: A Fundamental Characteristic of Meaning Making Interactions in High School Science Lessons. Science Education, 90(4), pp. 605-631, 2006.

SCOTT Phil H., ASOKO, H. M. \& DRIVER, Rosalind. H. Teaching for Conceptual Change: a review of strategies. Research in Physics Learning: Theoretical Issues and Empirical Studies. Proceedings of an International Workshop, 1991.

SILVA, Fábio Augusto Rodrigues $\mathbf{O}$ perfil conceitual de vida: ampliando as ferramentas metodológicas para sua investigação. Belo Horizonte, Dissertação de Mestrado em Educaçãon da UFMG, 2006.

SMITH, Edward E. \& MEDIN, Douglas L. Categories and concepts Cambridge, Massachusetts: Harvard University Press. 1981.

SOLSONA, Nuria; IZQUIERDO, Merce. \& JONG, Onno Exploring the development of students' conceptual profiles of chemical change. International Journal of Science Education, 25(1), p. 3-12, 2003

SPADA, H. Conceptual change or multiple representations? Learnig and Instruction, 4(1), 1994 apud VOSNIADOU, 1999

STRIKE, Kenneth K.A. \& POSNER, George J. Conceptual change view of learning and undertanding. In WEST, L. \& PINES, L. (Eds.), Cognitive Structure and conceptual Change, pp. 211-231). Orlando: Academic Press, 1985 
TREAGUST, David. F. Development and use of diagnostic tests to evaluate students' misconceptions in science. International Journal of Science Education, 10 (2), pp. 159$169,1988$.

VASCONCELOS, Alexsandra Cassol de \& SOUZA, Marjane Bernardy As noções de educação e disciplina em pais que agridem seus filhos. Psico, 37(1), pp. 15-22, jan./abr, 2006.

VIENNOT, Laurence Spontaneous reasoning in elementary dynamics European Journal Science Education, 1(2), p. 205, 1979

VIGGIANO, Esdras \& MATTOS, Cristiano Rodrigues de A comparação das visões de ensinar e de aprender de professores de física em formação com base na abordagem comunicativa. In Atas do X Encontro de Pesquisa em Ensino Física. Londrina: SBF, 2006a.

VIGGIANO, Esdras \& MATTOS, Cristiano Rodrigues de A comparação das visões de ensinar e de aprender de professores de física em formação. In Atas do IV Semana da Educação. São Paulo: Faculdade de Educação da Universidade de São Paulo, 2006b.

VIGGIANO, Esdras \& MATTOS, Cristiano Rodrigues de A Construção de um Instrumento para o Levantamento do Perfil Conceitual de Ensinar e Aprender In Atas do XVII Simpósio Nacional de Ensino de Física São Luís: SBF, 2007.

VIGGIANO, Esdras \& MATTOS, Cristiano Rodrigues de Insucesso da Mudança Conceitual e noção de Perfil Conceitual: a necessidade de se pensar a Educação em Ciências numa perspectiva metaconcientizadora. In Atas VIII Encuentro Internacional de Educación en Física. Salto: Asociación de Profesores de Física del Uruguay, 2006c (no prelo).

VIGGIANO, Esdras \& MATTOS, Cristiano Rodrigues de $\mathbf{O}$ ensinar na visão de licenciandos em física: o papel do aprendiz, abordagem comunicativa e contextos de ensino. In Atas do V Encontro Nacional de Pesquisa em Ensino de Ciências. Bauru: ABRAPEC, 2005.

VIGOTSKI, Lev Seminovich A construção do pensamento e da linguagem. (Trad. Paulo Bezerra). São Paulo: Martins Fontes, 2001.

VIGOTSKI, Lev Seminovich A Formação Social da Mente. São Paulo: Martins Fontes, 2000.

VIGOTSKII, Lev Seminovich Aprendizagem e Desenvolvimento Intelectual na Idade Escolar In VIGOTSKII, Lev Seminovich; LURIA \& LEONTIEV, 1988.

VIGOTSKII, Lev Seminovich; LURIA, Alexander Romanovich \& LEONTIEV, Alexis N. Linguagem, Desenvolvimento e Aprendizagem (trad. Maria da Penha Villalobos) $4^{\text {a }}$ ed. São Paulo: Ícone Editora e EDUSP, 1988.

VIGOTSKY, Lev Seminovich \& LURIA, Alexander Romanovich Tool and symbol in child development. In René Van der Veer \& Jaan Valsiner (orgs.) The Vygotsky Reader. Cambridge: Blaclwell, pp.106-107;120-127;132-135-135;140-146, 1994

VILA, Ignasi El espacio social en la construcción compartida del conocimiento. Educar 2223, pp. 55-98, 1998.

VILLANI, Alberto Conceptual Change in science and science education. Science Education, 76 (2), pp. 233-237, 1992. 
VOSNIADOU, Stella Conceputal Change Research: State of the Art and Future Directions In New Conceptual Change Approaches in Science Eduction SCHONTZ, Wolfgng; VOSNIADOU, Stella \& CARRETERO, Mario New Perspectives on Conceptual Change. New York: Pergamon, pp. 3-14, 1999.

VYTOTSKY, Lev Semenovich \& LURIA, Alexander Romanovich Estudos sobre a história do comportamento: símios, homem primitivo e criança (Trad. Lólio de Oliveira), Porto Alegre: Artes Médicas, 1996.

WANDERSEE, James H., MINTZES, Joel J., \& NOVAK, Joseph D. Research on alternative conceptions in science. Handbook of Research of Science Teaching and Learning, (ed. Dorothy L. Gabel), New York: Macmillan Publishing, pp. 177-210, 1994.

WITTER, Geraldina Porto (org.) Ciência, Ensino e Aprendizagem. São Paulo, Alfa-Omega, 1975.

ZAÏNE, Najoua Conceptual profile of pupils and students of the radiation. In Proceeding of 41th International Conference E.S.E.R.A. (European Science Education Research Association) on Research and Quality of Science Education, 2003.

ZEILIK, Michael Classroom Assessment Techniques Conceptual Diagnostic Tests. World Wide Web: <http://www.flaguide.org/cat/diagnostic/diagnostic1.php $>$. Acessado em 14/02/2005, 2005.

ZEILIK, Michael; SCHAU, Candace \& MATTERN, Nancy. Misconceptions and their change in university-level astronomy courses. The Physics Teacher, 36: 104-107, 1998.

ZEILIK, Michael; SCHAU, Candace, MATTERN, Nancy, HALL, Shannon, TEAGUE, Kathleen., \& BISARD, W. Conceptual astronomy: A novel model for teaching postsecondary science courses. American Journal of Physics, 65 (10): pp. 987-996, 1997.

ZYLBERSZTAJN, Arden Concepções espontâneas em física: exemplos em dinâmica e implicações para o ensino. Revista de Ensino de Física 5 (2), p. 3-16, 1983. 
APÊNDICES 


\section{Apêndice A: O Questionário Piloto}

Neste apêndice discutimos o desenvolvimento e a análise do questionário piloto, o qual teve a função de oferecer indicativos da qualidade das perguntas e também de testar as categorias definidas a priori. Com o teste das categorias essas poderiam ser ajustadas e modificadas para contemplar o problema de pesquisa efetivamente, isto é, realizar o levantamento dos perfis conceituais de ensinar e de aprender. A análise do questionário piloto ocorreu em aprofundamento no referencial teórico e levantamento acerca dos conceitos ensinar e aprender. Como pano de fundo deste capítulo, deve-se assumir os métodos para construção de questionários e a visão de um questionário para medição de perfil conceitual ora discutida.

Como ponto de partida para a construção do questionário final, realizamos a construção de um questionário piloto. Esse tinha a função de

\section{A.1 A Construção}

Como ponto de partida para criação do questionário piloto, foram escolhidas categorias a priori que pareciam interessantes e suficientes para o levantamento dos perfis conceituais de ensinar e de aprender. As categorias foram agrupadas em três dimensões com três categorias em cada, e são representadas na Tabela 43.

Tabela 43: Categorias utilizadas para construção do questionário piloto

\begin{tabular}{lccc}
\hline \hline Dimensões & Tipo de Interação & $\begin{array}{c}\text { Teorias de } \\
\text { aprendizagem }\end{array}$ & Racionalidade \\
\hline Categorias & Dialógica & Inatista & Criterial \\
\cline { 2 - 4 } & Autoritária & Interacionista & Semi-criterial \\
\cline { 2 - 4 } & & Ambientalista & Não-criterial \\
\hline \hline
\end{tabular}

O questionário piloto ${ }^{37}$ foi dividido em duas partes. A primeira foi constituída de nove questões, sendo: "Nome”, "Curso", "Se leciona”, "Há quanto tempo leciona”, "Em qual nível de ensino leciona", "Quantas horas semanais de trabalho docente", "Se tem uma concepção

\footnotetext{
${ }^{37}$ Cópia no Apêndice C
} 
religiosa", "Se já vez outro curso superior" e o "Sexo". Tal parte era seguida de um breve texto que se referia ao sigilo dos dados e de instruções acerca de como responder o questionário.

A segunda parte foi constituída de 78 questões com base nas dimensões e categorias. Dessas, sete eram fechadas, de forma que o indivíduo somente podia optar pelas opções sugeridas, não havendo casos em que o indivíduo poderia colocar algum item que não estivesse na lista de alternativas. Todas as outras 71 questões eram abertas curtas e simples, podendo ou não ser complementar a uma questão fechada.

Nas instruções sobre como responder ao questionário foi dada a possibilidade de as respostas serem feitas por meio de desenhos. Porém a forma de expressão mais próxima a um desenho que verificada foi semelhante a carinhas, chamadas de emoticons ou smileys (símbolos comumente utilizados em programas de comunicação via internet).

Foram 52 grupos de questões no total. Quando havia uma questão fechada, essa era a primeira questão do grupo e as seguintes eram complementares. Para ficar claro, apresentamos na Figura 5 o exemplo de um bloco de questões.

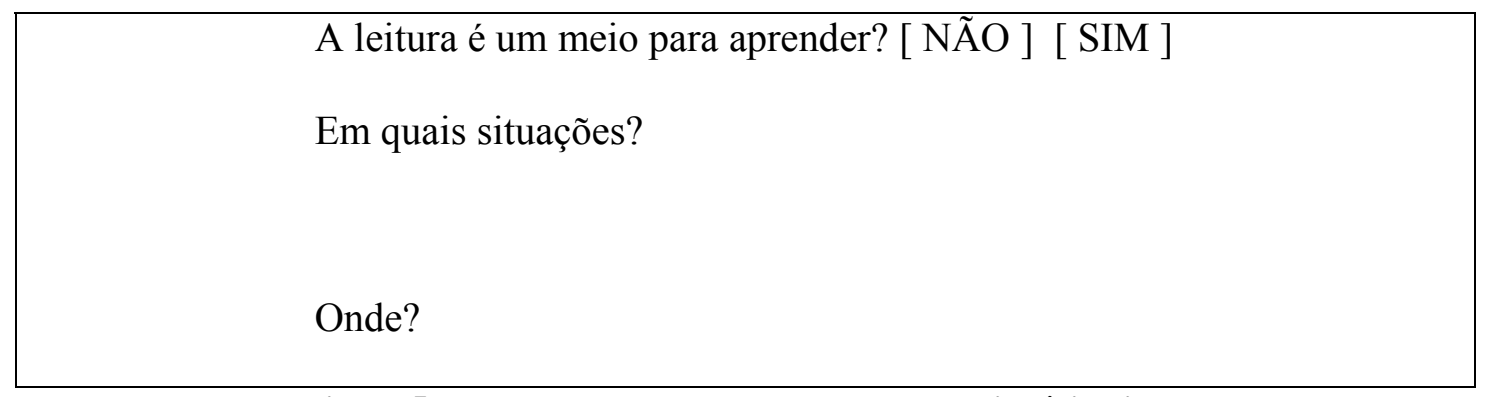

Figura 5: Exemplo de bloco de questão do questionário piloto

A estrutura de nove dos 52 grupos foi composta de uma questão fechada sobre uma afirmativa, seguida de uma ou duas perguntas complementares, que normalmente tinham o enunciado "De qual forma?” (ou “Como?”) e "Onde?”. 
Utilizamos uma mesma história em quadrinhos em duas questões, dispostas em páginas diferentes. A questão que aparecia primeiro no questionário não tinha a última cena, enquanto a segunda estava completa (vide questionário Anexo 4). Após a apresentação das charges existiam questões para identificarmos a diferença de respostas com a inserção do último quadro.

O questionário piloto foi aplicado na turma da disciplina Elementos $e$ Estratégias para o Ensino de Física ${ }^{38}$, oferecida pelo Instituto de Física da USP, no período matutino do ano de 2005. Não ocorreu escolha prévia dos estudantes que responderiam ao questionário. Contudo, para termos o maior número de estudantes possível, negociamos com o professor da disciplina a aplicação no dia da avaliação final do curso. Devido à data, pode-se imaginar que os estudantes poderiam ficar tensos com a avaliação que ocorreria em seguida. Porém, acreditamos que isso não ocorreu uma vez que o professor avisou que a prova seria uma auto-avaliação curta, que poderia ser respondida em poucos minutos.

\section{A.2 A Análise}

Após a aplicação fizemos uma leitura geral de todos os questionários, procurando identificar as questões que não atendiam à expectativa de pesquisa. Tal leitura foi no sentido de verificarmos a boa compreensão e se as perguntas realmente foram respondidas e não no sentido de encontrar explicitamente determinadas respostas. Constatamos que o instrumento foi muito longo, já que vários estudantes não chegaram ao final do mesmo e que as últimas perguntas eram respondidas de forma evasiva, não trazendo elementos interessantes à pesquisa.

Para a tabulação e análise dos dados construímos um banco de dados utilizando o programa Microsoft Access. Alimentamos o banco de dados com algumas respostas selecionadas a partir da leitura geral dos questionários. Já discutimos a funcionalidade do banco

\footnotetext{
${ }^{38}$ A disciplina é apresentada na Seção 4.1.2.
} 
de dados anteriormente, mas cabe voltar a destacar que esse permitiu a manipulação e o agrupamento dos dados de acordo com necessidades de pesquisa. Um caso ilustrativo de agrupamento é que se pode colocar em uma coluna apenas as respostas de uma questão e em outra coluna a categorização, portanto não há visualização da pergunta ou nem mesmo o nome do respondente que a respondeu. Outro exemplo prático é a construção de tabelas nas quais cada coluna correspondia às respostas de uma pergunta para um mesmo respondente.

As respostas comparadas mostraram diferenças. Na primeira questão do grupo história em quadrinho, os estudantes responderam que era um macaco, um homem etc. $\mathrm{Na}$ segunda questão qualificaram o indivíduo como alguém que ensina, como um professor ou algo parecido. Portanto, constatamos que a inserção do último quadrinho modificou o padrão das respostas. Isto porque os elementos comunicativos foram alterados, modificando as regras de reconhecimento de contexto, implicando na mudança das regras de realização, levando os indivíduos a utilizarem outra zona do perfil conceitual. O indivíduo ao fundo foi qualificado na segunda questão, deixando de ser uma pessoa comum (ou animal) para um sujeito que ensina.

Os respondentes por vezes criticaram a forma de ensinar-aprender. Isso pode indicar que alguns dos estudantes foram capazes de perceber que existem diversas formas de ensinar-aprender, valorizando mais uma forma que outra. A valorização refere-se à dimensão axiológica do perfil conceitual. Há indicativos nas repostas de que os estudantes identificam o contexto, porém não concordam com o desenrolar da "atividade educativa" naquele tipo de contexto. Isto porque a predominância das dimensões do contexto de leitura difere da elaboração da história.

Na análise do questionário constatamos que algumas palavras ou expressões no enunciado também deixavam margem para respostas mais vagas. Enquanto outras (mais 
objetivas) traziam elementos mais claros e categorizáveis. Neste sentido, as perguntas deveriam ser bem compreendidas levando os respondentes a compreenderem e responderem adequadamente às mesmas. Além disso, uma parte das perguntas deveria remeter os indivíduos para certos contextos. Contudo verificamos que as expressões utilizadas inadequadamente não remeteram os indivíduos aos contextos objetivados. Apresentamos na Tabela 44 algumas das palavras ou expressões, o sentido esperado, o obtido e as possíveis alternativas para se obter melhores respostas.

Tabela 44: Expressões que geraram dúvida para a resposta dos estudantes, o sentido que se esperado e obtido e expressões ideais

\begin{tabular}{|c|c|c|c|}
\hline Expressão / palavras & Sentido esperado & Sentido obtido & Expressões Alternativas \\
\hline Em quais situações... & Como & Local & Como... \\
\hline De qual forma... & Como & Local; o que é & Como \\
\hline Qual é (são)... & $\begin{array}{l}\text { Destaque de um ou } \\
\text { alguns tipos }\end{array}$ & Como & Cite* $^{*}$ \\
\hline Descreva... & $\begin{array}{l}\text { Descrição física } \mathrm{e} \\
\text { didática }\end{array}$ & $\begin{array}{l}\text { Apenas descrição } \\
\text { física }\end{array}$ & $\begin{array}{l}\text { Destaque características físicas } \\
\text { didáticas }\end{array}$ \\
\hline Explique. (após frase) & $\begin{array}{l}\text { Explicação completa } \\
\text { da situação }\end{array}$ & $\begin{array}{l}\text { Apenas um ou } \\
\text { outro aspecto }\end{array}$ & Explique (antes da frase) \\
\hline
\end{tabular}

Durante a análise do questionário como um todo, concluímos que muitas das perguntas foram mal compreendidas ou não levaram ao efeito esperado. Quando utilizamos "onde" obtivemos respostas de "quando"; “de qual forma” obtivemos "onde”; e assim por diante. Apesar de não ser esperada tal confusão, em uma leitura isso mostrou-se plenamente compreensível pois o questionário possuía várias perguntas semelhantes, com pequenas semelhanças, sobretudo no início das questões. Além disto, o questionário muito longo faz com que os respondentes não prestassem a devida atenção às perguntas devido à exaustão. A falta de compreensão acarretou em imprecisão no sentido e significado que os estudantes queriam atribuir a suas respostas. Portanto, fica claro que o tamanho do questionário influiu diretamente na qualidade das respostas para categorização. Por este motivo mostrou-se indispensável que, quando da construção do instrumento final, que reduzíssemos a extensão do mesmo. Além da 
dificuldade encontrada na categorização, perdemos elementos importantes para a pesquisa relacionados ao onde (formal e não-formal) e às formas (Como e Quem) devido à confusão dos respondentes.

É relevante discutir brevemente as respostas de algumas questões que auxiliaram no desenvolvimento posterior da pesquisa, porém não é estendemos a análise devido às limitações e à natureza dos dados obtidos. As limitações dos dados devem-se ao objetivo do questionário piloto, que era auxiliar na construção de um instrumento mais adequado para o levantamento dos perfis conceituais. Os dados não são plenamente apropriado por possuírem muitas variáveis inesperadas. As limitações ocorreram pois foi o primeiro instrumento elaborado e aplicado com o objetivo de delineamento dos contextos e utilização das zonas de perfil conceitual.

As perguntas com a história em quadrinhos estavam colocadas ao final do questionário, por isso muitos dos estudantes não as responderam. Estas se referiam a quem era e qual a função do indivíduo ao fundo da cena. Na charge há várias possibilidades de se interpretar o ensinar-aprender, primeiramente o aprendizado por experiência ou contato direto com o objeto, o aprendizado por estímulo e resposta e o ensinar-aprender dado através da interação social. A forma como a interação ocorre também foi caracterizada, uma vez que "o indivíduo que ensina" na segunda pergunta somente interage após a atividade do aprendiz - queimar a mão - se concretizar. Nas poucas respostas que tivemos das questões referentes à história em quadrinhos, concluímos que as modificaram sensivelmente ao coloca-se o último quadrinho. Na primeira questão, os estudantes consideraram vários atributos e mesmo nomes ao indivíduo, como "homem das cavernas", "macaco" etc. Mas não detectamos menção a alguém com função de professor, tutor ou parceiro mais capaz. 
Quanto à questão que apresentava o último quadrinho, os respondentes acabam nomeando e atribuindo características próprias a quem ensina, mesmo que de forma negativa. Esse fato é interessante, uma vez que indica que a colocação de um quadrinho modifica o estabelecimento dos contextos. Assim, identificamos indícios fortes da ocorrência da mudança de contexto de uma questão a outra. Isso vai ao encontro da primeira pergunta de trabalho que se refere à possibilidade das questões serem delimitadoras de contexto. Apesar dos resultados obtidos com as questões da história em quadrinhos, as mesmas não foram incluídas no questionário final para estabelecer uma extensão adequada do instrumento.

Como dissemos anteriormente, além de analisar o questionário de forma geral, verificando quais questões haviam sido respondidas e compreendidas, utilizamos algumas questões para validar as categorias prévias. As principais questões analisadas foram: "O que é [ensinar/aprender]?”, “Como se [ensina/aprende]?”.

\section{A.3 A validação das categorias}

A partir das questões selecionadas procuramos validar as categorias Concepções de Educação e Onde. A análise foi realizada a partir das categorias utilizadas para construção do questionário piloto.

\section{A.3.1. Dimensão Concepções de Educação}

Apesar de chamamos a dimensão em questão de Concepções de Educação ${ }^{39}$, este nome foi modificado por diversas vezes no decorrer da pesquisa. Inicialmente optamos por Relação, com as subcategorias Dialógico e Autoritário. Posteriormente, assumimos o nome Abordagem Comunicativa (MORTIMER \& SCOTT, 2003), com as categorias Dialógico e De Autoridade. Porém, durante a análise do questionário piloto (VIGGIANO \& MATTOS, 2005 e 2006a), consideramos que seria mais adequado substituir a dimensão proveniente da abordagem

\footnotetext{
${ }^{39}$ Esta seção é uma modificação do trabalho Viggiano e Mattos (2006b).
} 
comunicativa pelo que chamamos de Concepções de Educação, com as categorias Bancária e Problematizadora. Isto porque, a abordagem comunicativa mostrou-se mais adequada para estudos envolvendo o discurso dinâmico em sala de aula e não para as diversas representações de ensinar e aprender.

Apesar da significativa contribuição de Freire (1981) para conceber as representações de ensinar e aprender, julgamos necessário um aprofundamento e um estabelecimento de categorias mais claro nas categorias, como foi realizado no Capítulo 3. Voltamos a utilizar as categorias Dialógico e Autoritário, contudo como discutido em naquele. O principal ganho ao assumirmos as novas categorias realcionam-se ao fato de agregarmos uma categoria Duvidosa, que comporta características das outras duas categorias. Como discutimos, essa categoria é originária tanto da mescla das outras duas quanto da dificuldade de caracterização das outras duas. Tal categoria pode possibilitar a análise de um possível espectro intermediário, refletindo parte da complexidade e da relação entre os perfis conceituais de ensinar e aprender. Com o estabelecimento da categoria Duvidosa, a categorização foi significativamente facilitada, ficou mais clara e mesmo precisa. A validação quanto à abordagem comunicativa pode ser verificada em (VIGGIANO \& MATTOS, 2005).

Comparamos a categorização na dimensão das Concepções de Educação das questões "O que ensinar?" e "O que é aprender?". Selecionamos todos os questionários que continham as duas perguntas respondidas, totalizando 41 .

A Categoria A foi utilizada para designar Concepção Autoritária; Categoria D para Concepção Dialógica; e Categoria M para a Categoria Duvidosa.

Apesar de categorizadas como Duvidosas, algumas das respostas respondiam à pergunta não se adequando ao recorte teórico, como por exemplo “O que é aprender? É ampliar 
o conhecimento". O sentido geral das expressões utilizadas para categorização das respostas são apresentadas na Tabela 45 .

Tabela 45: Expressões típicas utilizadas da categoria autoritária

\begin{tabular}{ll}
\hline \hline Ensinar & Aprender \\
\hline Introduzir & Absorver \\
Transmitir & Adquirir \\
Passar & Assimilar \\
Mostrar & Receber \\
Fazer & Tomar conhecimento \\
Ministrar & Apropriar \\
& Acumular \\
\hline \hline
\end{tabular}

Duas respostas foram enquadradas em duas categorias, pois o texto pôde ser dividido em dois ou mais trechos com características cabíveis nas Categorias $A$ e $P$.

Destacamos alguns exemplos de respostas fornecidas às questões "O que é Ensinar?”(Q1) e a “O que é aprender?” (Q2), apresentados na Tabela 46.

Tabela 46: Seleção de respostas dadas a Q1 e Q2 no questionário piloto.

\begin{tabular}{|c|c|c|c|}
\hline $\mathbf{E}^{* *}$ & Q1 - O que é ensinar? & $\mathrm{C}^{*}$ & Q2 - O que é aprender? \\
\hline 05 & É transmitir conhecimento e vivências. & A & $\begin{array}{l}\text { Adquirir conhecimento, tanto da área escolar como } \\
\text { na experiência pessoal de vivência de cada um. }\end{array}$ \\
\hline 26 & $\begin{array}{l}\text { Transmitir conhecimento e auxiliar na } \\
\text { condução à aprendizagem }\end{array}$ & & $\begin{array}{l}\text { É tomar algo (conhecimento) como verdade } \mathrm{e}_{\mathrm{A}} \\
\text { difundir esse conhecimento. }\end{array}$ \\
\hline 48 & Ensinar é dividir o conhecimento & D & É acumular conhecimento. $\quad$ A \\
\hline 07 & É trocar experiência & $\mathrm{D}$ & É compreender, absorver. \\
\hline 41 & É estimular o senso crítico do aluno. & $\mathrm{D}$ & $\begin{array}{l}\text { É estimular o senso crítico e saber interpretar as } \\
\text { diversas informações do nosso dia a dia }\end{array}$ \\
\hline 51 & $\begin{array}{l}\text { É passar, transmitir o seu conhecimentc } \\
\text { a outras pessoas. }\end{array}$ & & $\begin{array}{l}\text { Adquirir conscientemente, refletir, questionar os } \mathrm{D} \\
\text { conhecimentos que lhe são apresentados. }\end{array}$ \\
\hline
\end{tabular}
Legenda: *Categoria; **Estudante

Ao compararmos a categorização de cada uma das respostas, verificamos que ocorre a mesma categorização para as duas perguntas de alguns estudantes. O Estudante 41, categorizado em $D$ em Q1, apesar de utilizar a palavra "estimular", que poderia indicar uma concepção autoritária da educação escreve "senso crítico", portando não se restringindo a 
elementos externos ou independentes aprendiz, valorizando o conhecimento e o pensamento deste. A resposta do mesmo estudante à Q2 poderia ser utilizada para ensinar sem perder o sentido geral, mostrando uma relação entre os conceitos ensinar e aprender para o indivíduo.

Os Estudantes 05 e 26, nos contextos estabelecidos na aplicação do questionário, concebem a educação como sendo autoritária. Percebemos que os verbos (transmitir / tomar / adquirir) são os principais indicadores da categoria autoritária, provavelmente por não haver a consideração do outro no processo educativo. O Estudante 26 pode indicar uma pequena tendência para a categoria dialógica em Q1, uma vez que "auxiliar” não implica na transmissão do conhecimento, mas analisando a resposta por completo, fica evidente a predominância da tendência autoritária na mesma.

Comparamos as respostas dos Estudantes 07 e 48 para Q1 e Q2, identificamos que em Q1, estas se enquadram na categoria dialógica, enquanto que em Q2 na categoria autoritária, mostrando desvinculação entre ensinar e aprender.

O Estudante 51 é categorizado na categoria autoritária em Q1 e dialógica em Q2. Notamos que em Q2 o verbo não é suficiente para determinar a categoria (como geralmente ocorre na categoria autoritária), pois ao referir-se a aprender como "Adquirir conscientemente, refletir, questionar os conhecimentos que lhe são apresentados", qualifica o aprendiz como indivíduo ativo na relação, não caracterizando a pura deposição de conhecimento, portanto sendo a categoria $D$ mais adequada.

O Estudante 41 foi o único que teve suas respostas das duas questões categorizadas na categoria dialógica. Isto indica que de alguma forma, não há correspondência direta entre as categorias para ensinar e aprender nos contextos estabelecidos pelas questões. 


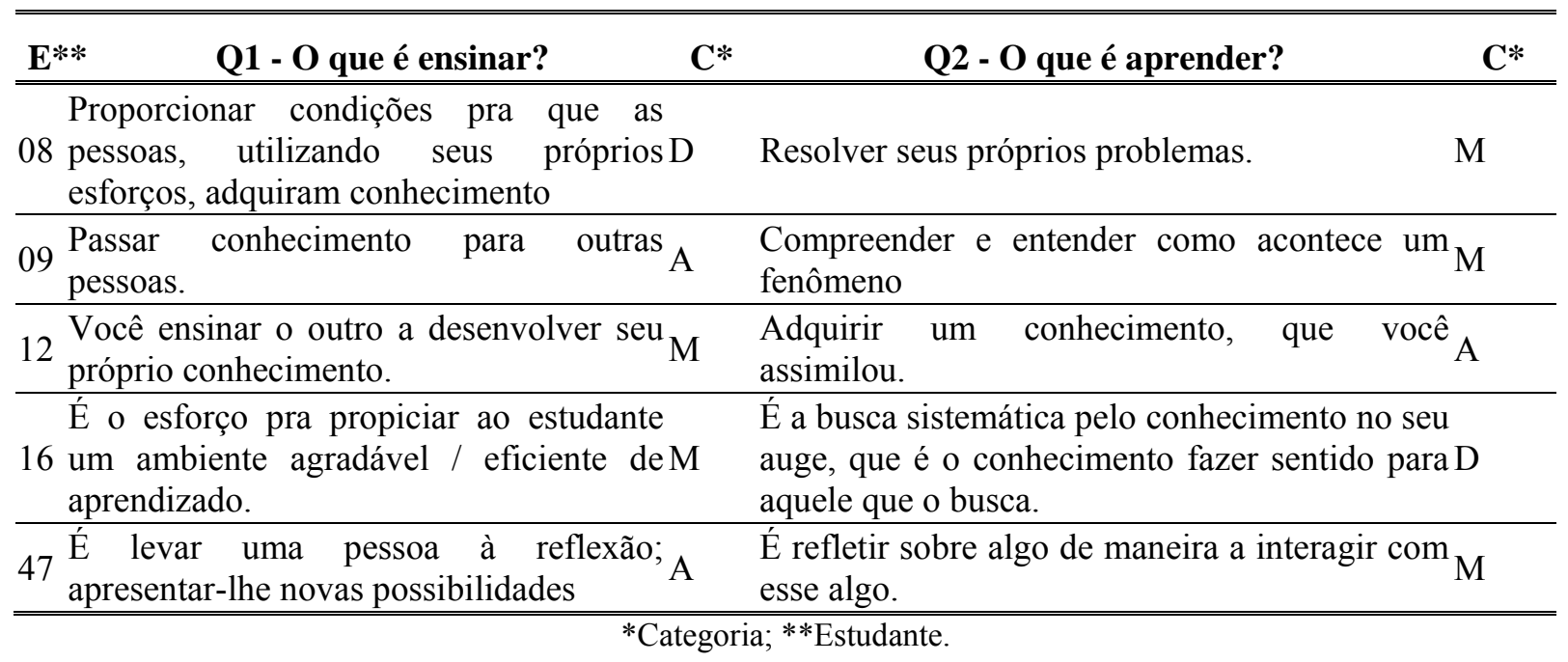

Analisando algumas das respostas que foram categorizadas como Duvidosas na Tabela 47 identificamos termos que não se enquadram nas categorias autoritária ou dialógica ou são imprecisos não permitindo uma categorização adequada em tais categorias. O Estudante 12 (Q1), por exemplo, tende para a consideração do outro e escrevendo "ensinar o outro como desenvolver seu conhecimento". Porém, ensinar, como podemos ver na premissa implícita desta pesquisa pode ser autoritário ou dialógico, causando dúvida para na categorização.

O Estudante 16 (Q1) deixa dúvidas ao referir-se ao ambiente agradável. Poderíamos conceber, por exemplo, segundo algumas teorias do desenvolvimento, que um local com instrumentos de estímulos positivos e negativos poderiam gerar a aprendizagem, mesmo sem a necessidade de um educador envolvido no processo. Basicamente algo que lê a mensagem, interpreta como certo ou errado e desencadeia um estímulo, como por exemplo, um choque elétrico.

A resposta Q2 do Estudante 08 não fornece elementos de consideração do outro na atividade, mas também não se refere ao processo de aprendizagem explicitamente. Parece que o estudante refiriu-se ao "o que é saber?" e não ao "o que é aprender?" ou se respondeu o correspondente para o produto do aprender, a aprendizagem. 
A resposta Q2 do Estudante 47 implica na interação com "algo". Este algo, caso refira-se a uma pessoa - poderia ser enquadrado na categoria dialógica. Entretanto, o respondente não citou "alguém", ou seja, deixou em aberto se "algo" é um indivíduo ou simplesmente objeto. Neste caso, podemos relacionar algo à máquina de estímulos e repostas anteriormente citada, com a inserção de uma reflexão sobre o processo. Contudo não é possível identificar indícios da consideração de construção conjunta de conhecimento.

Duas das respostas (apresentadas na Tabela 48) foram classificadas nas categorias autoritária e dialógica. O método de categorização dupla é limitado por não possibilitar uma contagem simples e uniforme. Uma possibilidade de categorização para as duas questões, dada a criação da categoria duvidosa, é categorizar as duas respostas nesta categoria..

Tabela 48: Respostas com dupla categorização.

\begin{tabular}{|c|c|c|c|}
\hline $\mathbf{E}^{* *}$ & Q1 - O que é ensinar? $\quad C^{*}$ & Q2 - O que é aprender? & $\mathbf{C}^{*}$ \\
\hline 42 & $\begin{array}{l}\text { Estimular o pensar, além de transmitir } \mathrm{A} / \mathrm{D} \\
\text { informações }\end{array}$ & Adquirir conhecimento e saber pensar. & A \\
\hline 45 & $\begin{array}{l}\text { Ensinar é muitas coisas, passar conhecimento, } \\
\text { influenciar, ajudar, atrapalhar acho que não dá A/D } \\
\text { pra definir. }\end{array}$ & Absorver qualquer coisa que se queira & A \\
\hline
\end{tabular}

Categoria; $* *$ Estudante.

A resposta do Estudante 42 à Q1 indica que ele é categorizado nas categorias A e D ensinar, e mesmo que o respondente sabe que existem duas formas de ensinar. Portanto podemos dividir a resposta do estudante em duas partes, encontrando duas formas de conceber o ensinar, sendo dialógica em "estimular o pensar" e autoritária em "transmitir informações". Enquanto isso, o Estudante 45 explicita que ensinar pode ser encarado de várias formas devido à expressão "ensinar é muitas coisas", evidenciando que também considera múltiplas formas de ensinar. Para ele, ensinar pode ser autoritário ("passar conhecimento") e dialógico (“ajudar"). Verificou-se que os dois estudantes, quando se referem a aprender, são categorizados na 
categoria autoritária, não evidenciando múltiplas formas de aprender, como ocorrido para ensinar.

Na Tabela 49 são apresentadas, por meio de porcentagens, a relação entre a categorização das respostas de Q1 e Q2.

Tabela 49: Relação entre a categorização das respostas em Q1 e Q2

\begin{tabular}{lll}
\hline \hline \multicolumn{1}{c}{ Ensinar (Q1) } & \multicolumn{1}{c}{ Aprender (Q2) } & Correspondência \\
\hline \multirow{3}{*}{ Autoritária } & Autoritária & $63 \%$ \\
& Duvidosa & $12 \%$ \\
& Dialógica & $02 \%$ \\
\hline Duvidosa & Autoritária & $02 \%$ \\
& Dialógica & $02 \%$ \\
\hline \multirow{3}{*}{ Dialógica } & Autoritária & $12 \%$ \\
& Duvidosa & $12 \%$ \\
& Dialógica & $02 \%$ \\
\hline \hline
\end{tabular}

Com base na Tabela 49 verificamos que $35 \%$ dos estudantes são categorizados em categorias diferentes para ensinar e para aprender. Demonstrando independência entre ensinar e aprender. Verificamos também que a correspondência da categorização ocorre mais significativamente na categoria autoritária $(63 \%)$ do que na dialógica $(2 \%)$.

Cerca de $26 \%$ dos estudantes, em ao menos uma das questões teve respostas categorizadas como duvidosas. Isso indica que as questões não definiram o contexto de forma a levar os estudantes ou que nos contextos em questão as categorias se misturam.

Nas respostas fornecidas à $\mathrm{Q} 1$, foi freqüente a expressão "troca de experiências" quando se referiam a ensinar. Em Q2, aprender é utilização prática de um conhecimento, relacionado apenas com quem aprende. Desta forma, identificamos que nestes casos não há uma vínculo direto entre ensinar e aprender. 


\section{Conclusões preliminares}

A partir dos dados dispostos na Tabela 49, concluímos que a maior parte dos licenciandos em Física da amostra do questionário piloto considera que ensinar e aprender é unilateral, isto é, ocorre uma simples transmissão e recepção de conhecimento, ou seja, a relação estabelecida é autoritária. Mesmo assim, em algumas das respostas classificadas nessa categoria existiam referências aos aprendizes. Todavia essas não implicam, necessariamente, em ensinar como sendo dialógico.

Em todas as respostas classificadas como dialógicas, ocorre menção ao aprendiz. Isto indica, que para a amostra, considerar uma relação dialógica no ensinar implica, necessariamente, na consideração do aprendiz. Desta forma, verificamos que as categorias estabelecidas a priori efetivaram-se satisfatoriamente na análise.

Concluímos que as categorias autoritária e dialógica são apropriadas como ponto de partida para o levantamento das zonas de perfil conceitual de ensinar e de aprender. Chegamos a esta conclusão uma vez que conseguimos diferenciar na maior parte dos enunciados as duas categorias. Percebemos a maior parte da amostra, (65\%) teve ao menos uma das suas respostas analisadas classificada na categoria autoritária. Cerca de $30 \%$ dos estudantes da amostra, teve ao menos uma das respostas às questões analisadas classificada como dialógica.

Há indícios tanto do vínculo da não vínculo entre as categorizações das respostas nas categorias escolhidas. Mostrando que são necessários outros estudos para se identificar a possível relação, talvez utilizando respostas de outras questões, como era esperado em na fase exploratória propiciada pelo questionário piloto. 


\section{A.3.2. Dimensão Onde}

A dimensão onde é constituída de duas categorias relativas a explicitação ou indicação de um local específico que ocorre o ensino: escolar ou formal e genérico.

A Categoria Formal (F) é identificada quando aparecem palavras que mencionem um local ou formal, como por exemplo, a palavra aluno.

A Categoria Genérico $(G)$ ocorre quando aparecem respostas que não definem um contexto formal específico, ou este é duvidoso.

Uma categoria que poderia ser estabelecida é a não-formal, contudo os dados colhidos no questionário piloto não se mostraram adequados para se realizar a diferenciação entre genérico e não-formal. ${ }^{40}$

$\mathrm{Na}$ análise desta dimensão de categorias, verificamos que existe uma variedade de respostas quanto ao local em que se ensina. Várias respostas colocam o sujeito de forma clara auxiliando na caracterização do onde. A utilização termos "pessoa", "alguém" entre outros, sinaliza que o ensino pode ocorrer em lugares não-formais.

Contudo, algumas das respostas estão limitadas ao ensinar no contexto formal, restringindo a visão de ensinar, uma vez que desconsidera o aprendizado realizado informalmente no dia-a-dia.

Identificamos que quando os indivíduos eram questionados sobre "O que é ensinar?" são menos categorizados como Formal do que quando são perguntados “como se ensina?". Isso pode indicar que a substituição de "O que" por “como" pode acarretar na mudança dos contextos de resposta das questões. A categorização em formal em Q2 foi identificada principalmente através das palavras "classes", "aulas", “discípulos", "alunos" e "professores”.

\footnotetext{
${ }^{40}$ Os dados do questionário final possibilitaram tal diferenciação.
} 
Tabela 50: Seleção de respostas dadas às perguntas 11 e 40 categorizadas na categoria Onde?.

\begin{tabular}{|c|c|c|}
\hline QU & ES ON & Resposta \\
\hline & $17 \mathrm{G}$ & $\begin{array}{l}\text { É você passar para alguém conhecimentos que lhe tenham significado, e que se } \\
\text { possa utilizar em seu dia-a-dia. }\end{array}$ \\
\hline 11 & $18 \mathrm{G}$ & É passar o conhecimento e torna-lo fácil de ser passado adiante. \\
\hline 11 & $19 \mathrm{~F}$ & $\begin{array}{l}\text { Permitir que as pessoas aprendam por si mesmas, é, na verdade, acompanhamento } \\
\text { atencioso e presente. }\end{array}$ \\
\hline 11 & $21 \mathrm{G}$ & Transmitir conhecimentos a outros. \\
\hline & $24 \mathrm{~F}$ & $\begin{array}{l}\text { Transmitir seus conhecimentos, despertando no aluno interesse para que ele } \\
\text { construa suas próprias idéias. }\end{array}$ \\
\hline 40 & $01 \mathrm{~F}$ & Com elementos acessíveis aos alunos, com o cotidiano de quem está aprendendo. \\
\hline 40 & & Existem milhares de formas. Exemplo: aulas experimentais. \\
\hline 40 & $07 \mathrm{G}$ & Fazendo a pessoa pensar, refletir sobre o assunto. \\
\hline & & $\begin{array}{l}\text { Não existe um único jeito de ensinar apenas aquele que quer ensinar tem que se } \\
\text { adequar a seus alunos. }\end{array}$ \\
\hline 40 & $18 \mathrm{G}$ & Conhecendo quem precisa ser ensinado. \\
\hline 40 & $20 \mathrm{G}$ & Transmitindo conhecimentos. \\
\hline 40 & $24 \mathrm{G}$ & No dia a dia. \\
\hline
\end{tabular}

\section{Conclusões preliminares}

Com os resultados obtidos a partir da categorização, identificamos evidências que a dimensão Onde pode ser relevante para o levantamento dos contextos de utilização das zonas de perfil, uma vez que a formalidade, como analisada, refere-se ao espaço onde ocorre a interação. Neste sentido, o local, relacionado ao princípio comunicativo localizacional é influenciado na formalidade da relação educativa.

Nesta seção apresentamos apenas os resultados dos aspectos relevantes para a validação das categorias que fizemos em Viggiano e Mattos (2005). Contudo, é possível verificar nesse trabalho a relação entre as dimensões categóricas Concepções de Educação, Onde e Consideração do Aprendiz ${ }^{41}$.

Com os indicativos e as conclusões preliminares obtidas no questionário piloto aliado ao levantamento bibliográfico é possível construir-se um instrumento mais para medição dos perfis conceituais com delineamento de contextos. A análise discutida neste capítulo foi

\footnotetext{
${ }^{41}$ Esta dimensão foi posteriormente fundida em Concepções de Educação, e não foi profundamente analisada.
} 
direcionada principalmente para a validação das duas categorias que passamos a considerar como zonas de perfil conceitual que nas outras categorias. Alguns indicativos de delineamento contextual foram apresentados, mas sem um atenção especial. No próximo capítulo retomamos brevemente as mudanças introduzidas pela análise do questionário piloto e apresentamos o questionário final. Apresentaremos no próximo capítulo também, a análise do questionário final com dados mais consistentes e adequados para a identificação e o estudo dos contextos de utilização das zonas de perfil. 


\section{Apêndice B: Ementa da disciplina Elementos e Estratégias para o Ensino de Física \\ Ementa e Dados da disciplina Elementos e Estratégias para o}

Ensino de Física (FAP0356) ${ }^{42}$

Créditos Aula: 4

Créditos Trabalho: 0

Carga Horária Total: 60 horas

Tipo: Semestral

Pré-requisitos: cursado as disciplinas FGE271 - Eletricidade II FEP255

Mecânica dos Corpos Rígidos e dos Fluidos e mais 4 créditos em qualquer disciplina da FEUSP.

Programa

Construção histórica e individual do conhecimento científico. A problemática do ensino de física. Conteúdo de Física: concepção de ciência, enfoques, seleção de conteúdos. A realidade do aluno: Concepções alternativas dos estudantes nas diversas áreas. Análise de respostas de estudantes. Mudança Conceitual. Estratégias para o Ensino de Física: Métodos de Ensino; mapas conceituais; recursos didáticos apropriados a cada caso. A Resolução de Problemas; análise de problemas em aberto; modelos de resolução de problemas. A História da Ciência e suas funções no ensino de Física. O laboratório didático e suas funções no ensino de Física. Os vários tipos de atividade experimental. Pesquisas em Ensino de Física: abordagem qualitativa e quantitativa; uso de estatística não-paramétrica para a interpretação de dados.

\footnotetext{
42 Extraído e adaptado de IFUSP, Comissão de Graduação, World Wide Web: www.if.usp.br/grad. Acessado em 28/06/2007.
} 


\section{Bibliografia Indicada}

Rubem Alves. Filosofia da Ciência: introdução ao jogo e suas regras. SP: Brasiliense. pp.92107. 1981. Leitura suplementar: Karl Popper (1958). A lógica da pesquisa científica. SP:Cultrix. pp. 61-64 e 270-274.

Mario Bunge. Filosofia da Física. Lisboa: Edições 70. pp.11-20. 1973.

Henri Poincaré (1902). A ciência e a hipótese. Brasília: UNB. Pp.115-125. 1985.

Werner Heisenberg (1958). Física e filosofia. Brasília: UNB. pp 141-154. 1987.

Thomas Kuhn (1962). Estrutura das revoluções científicas. São Paulo: Perspectiva. pp. 29-42. 1982.

Thomas Kuhn (1962). Estrutura das revoluções científicas. São Paulo: Perspectiva. pp. 43-66. 1982.

Paulo Freire (1970). Pedagogia do oprimido. São Paulo: Paz e Terra. PP. 57-95. 1996.

C. Davis e Z. Oliveira. Psicologia na educação. São Paulo: Cortez. pp. 16-34. 1994.

C. Davis e Z. Oliveira. Psicologia na educação. São Paulo: Cortez. pp. 36-56. 1994. Leitura suplementar: C. Davis e Z. Oliveira. Psicologia na educação. São Paulo: Cortez. pp. 87-98. 1994.

E. Mortimer. Linguagem e formação de conceitos no ensino de ciências. BH: UFMG. pp. 3582. 2000 


\title{
Apêndice C: Cópia do questionário piloto
}

\author{
Questionário - Pesquisa em Ensino de Física \\ Turma: Elementos e Estratégia para o Ensino de Física
}

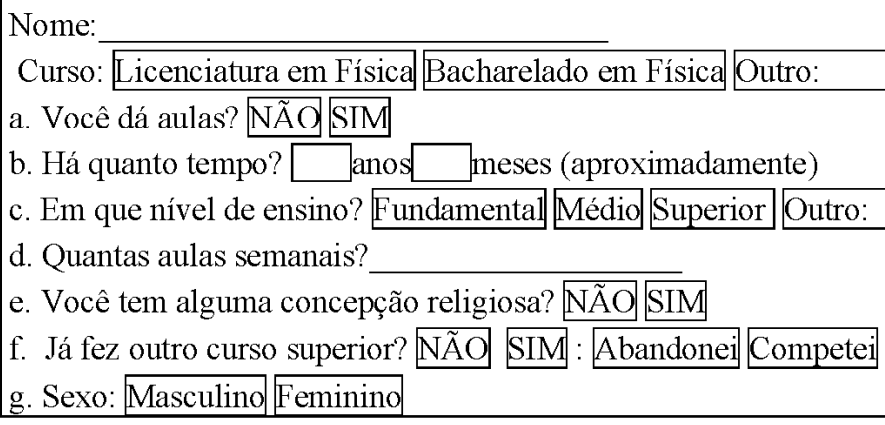

Este questionário NÃO tem função avaliativa. Ele tem como objetivo recolher dados para uma pesquisa em ensino de física.

Apenas os pesquisadores terão acesso à sua identidade, e a mesma não será divulgada por qualquer meio ou motivo e mesmo para o professor.

Algumas perguntas parecem ser iguais, mas não o são.

Neste momento, sua opinião é a mais importante para nossa pesquisa. É de grande relevância que você responda com suas palavras, de acordo com $O$ QUE VOCÊ PENSA, e não para o que o professor ou os pesquisadores esperam escutar.

Sinta-se a vontade para desenhar ou fazer esquemas que possam possibilitar uma comunicação mais eficaz. Basta desenhar no verso ou em folha anexa assinalando a questão a qual se refere.

Agradecemos desde já sua colaboração,

Os pesquisadores 


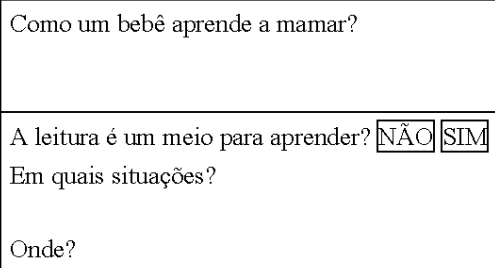

"Todo o conhecimento está na biblioteca" era uma frase comum há alguns anos. Hoje fala-se que "todo o conhecimento está na internet". Você acha que é possivel aprender com o computador? NẪ SIM

Em quais situações?

Onde?

Cite algumas frases que conhece que expressem o sentido de ensinar.

Qual é a forma ideal de se aprender?

O que é ensinar?

Como se aprende a estudar?

De qual forma a familia pode ensinar uma pessoa?

Como se aprende a jogar futebol?

Uma frase muito comum é "a educação vem de berço". O que a familia é capaz de ensinar para uma pessoa?

Além de professores, quais tipos de pessoas ensinam alguma coisa?

Em quais locais?

Em quais situações?

Você acha que é possível aprender individualmente? NÃO SIM

Em quais situações? 


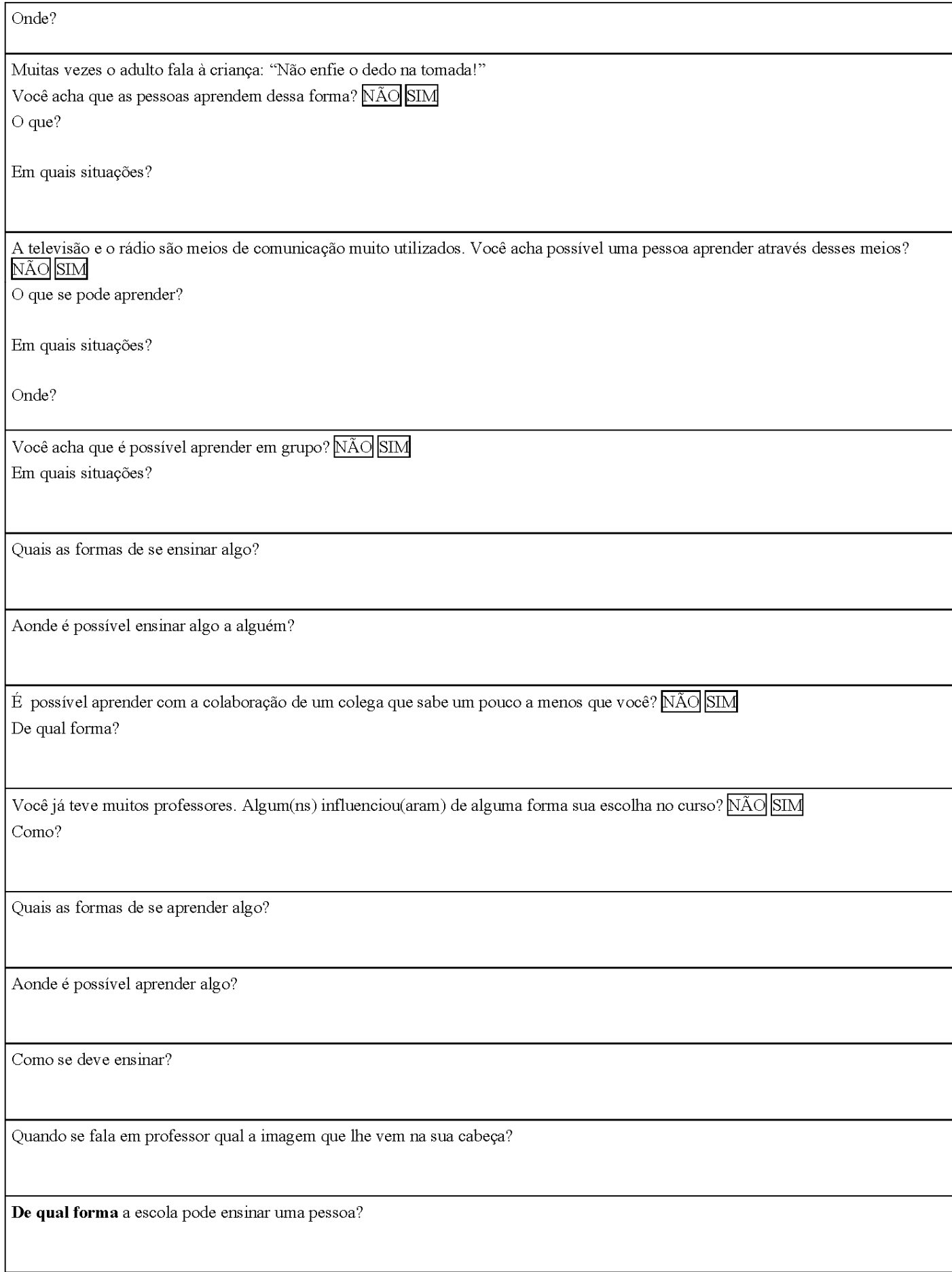




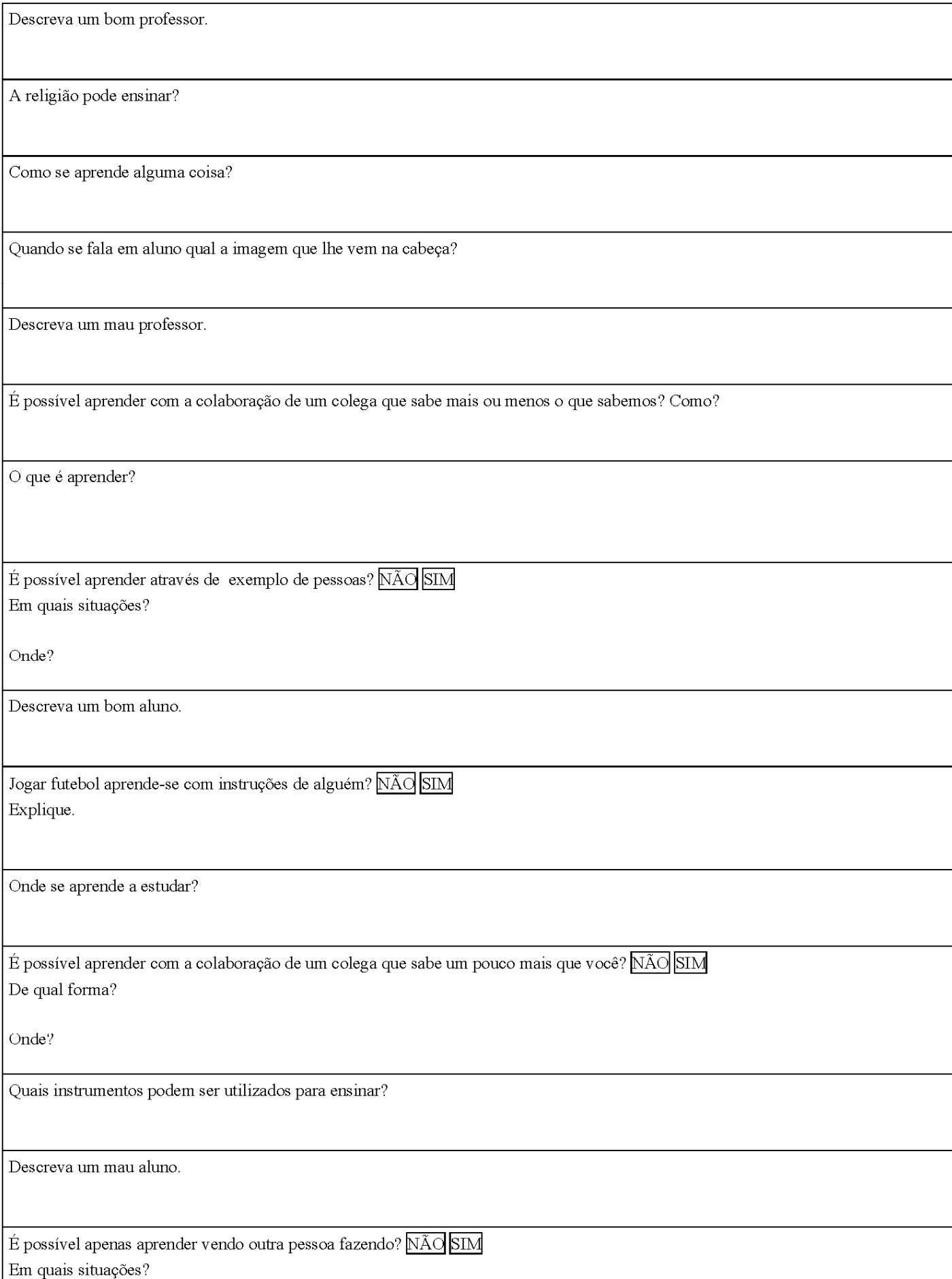

Em quais situações? 
Jogar futebol aprende-se individual mente ou em grupo? INDIVIDUALMENTE EM GRUPG Explique.

Quais instrumentos podem ser utilizados para aprender?

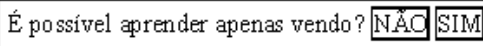

Em quais situações?

Onde?

É possivel aprender apenar por estar em um lugar propício? $\mathrm{NAO}$ SIM Quais lugares seriam assim?

SUECONSENOUS COMNES O/996

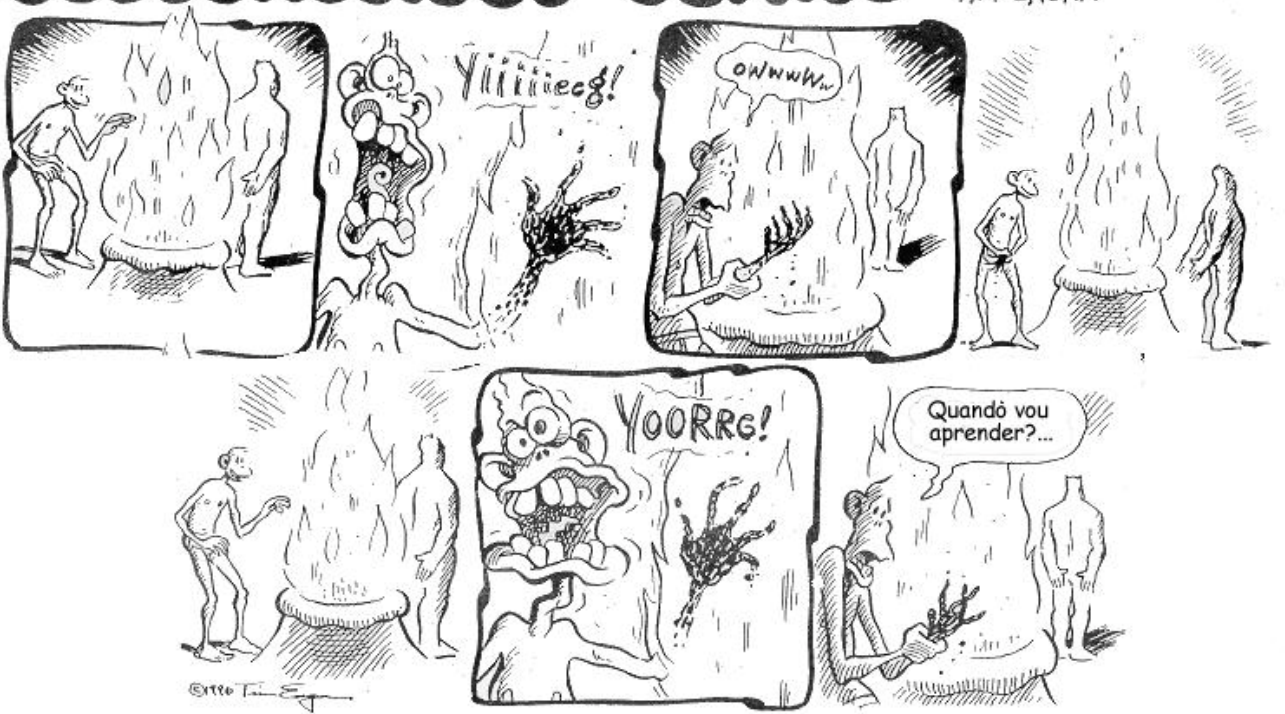

Descreva/di scuta sobre o que ocorre na charge apresentada acima

Quem é o indivíduo ao fundo da figura? Qual sua função? 
O que é um mal professor de fisica?

Como se aprende a ser "humano"?

Observe a inserção do último quadro na charge apresentada anteriormente, releia a história de forma a reinterpreta-la, caso ache coerente.

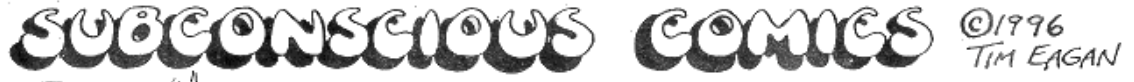

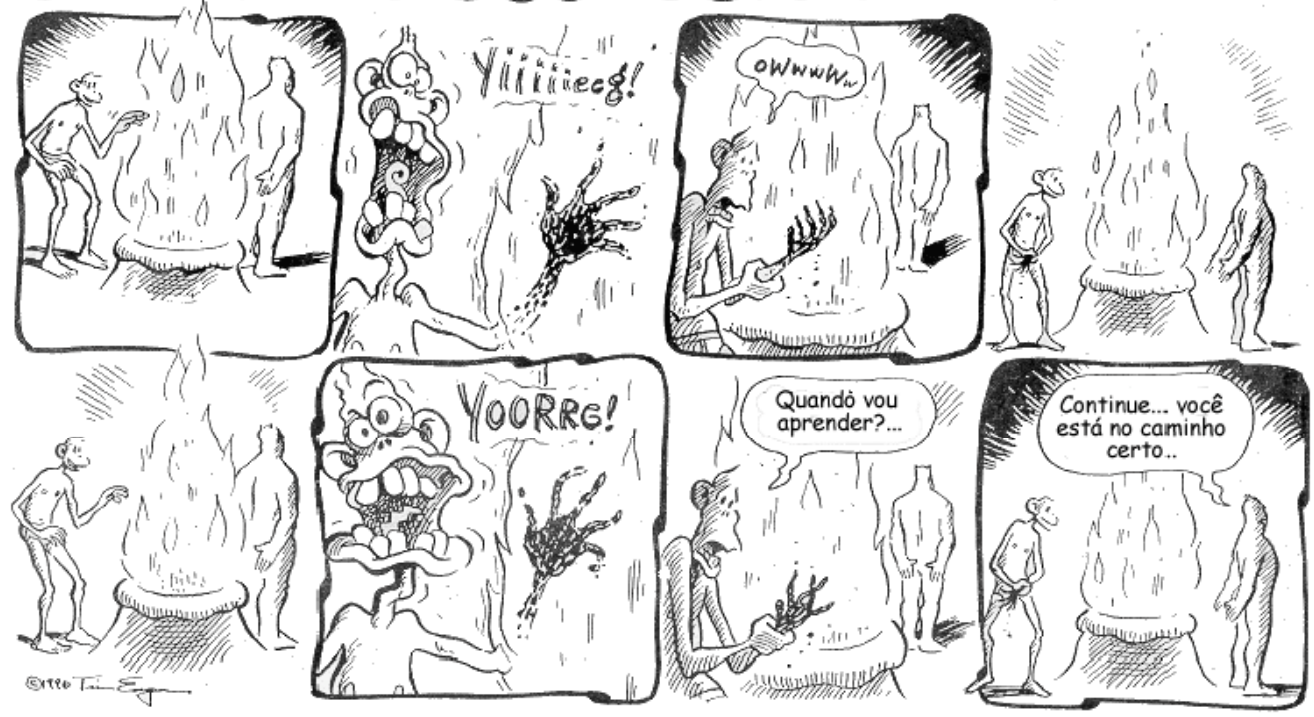

Descreva/discuta sobre o que ocorre na charge apresentada acima

Quem é o indivíduo ao fundo da figura? Qual sua função? 


\section{Apêndice D: Os modelos de questionários}

Questionário - Pesquisa em Ensino de Física

Nome:
E-mail:
Você leciona? [ NÃO ] [ SIM]
Há quanto tempo (aproximadamente)? __anos e __ meses
c. Em que nível de ensino?
$\quad$ [ Fundamental ] [ Médio ] [ Superior ] [ Cursinho ] [ Idiomas ]
[ Outro ] - Qual?
d. Quantas aulas semanais?
e. Qual sua concepção religiosa?
Sexo: [ Masculino ] [ Feminino ]
Curso: [ ] Licenciatura em Física / [ ] Bacharelado em Física
Período: [ ] Noturno / [ ] Diurno
Ano de ingresso:
Forma de ingresso:
[ ] Transferência Interna - Curso de origem:
[ ] Transferência Externa - Instituição/Curso de origem:
I ] Já graduado - Instituição/Curso:
[ ] Convênio / Intercâmbio - Instituição/Curso:
[ ] Vestibular
Quantos créditos você já cursou (aproximadamente):
Já fez outro curso superior?
[ SIM ]: [ Completei ] - Instituição/Curso:
[NÃO] [ Abandonei ] - Instituição/Curso:

Este questionário NÃO tem função avaliativa. Ele tem como objetivo recolher dados para uma pesquisa em ensino de física.

Apenas os pesquisadores terão acesso à sua identidade, e a mesma não será divulgada por qualquer meio ou motivo e mesmo para o professor.

\section{Algumas perguntas parecem ser iguais, MAS NÃO O SÃO.}

Neste momento, sua opinião é a mais importante para a pesquisa. É de grande relevância que você responda com suas palavras, de acordo com O QUE VOCÊ PENSA, e não o que o professor ou os pesquisadores esperam escutar.

Agradecemos desde já sua colaboração,

Os pesquisadores 
QUESTIONÁRIO W

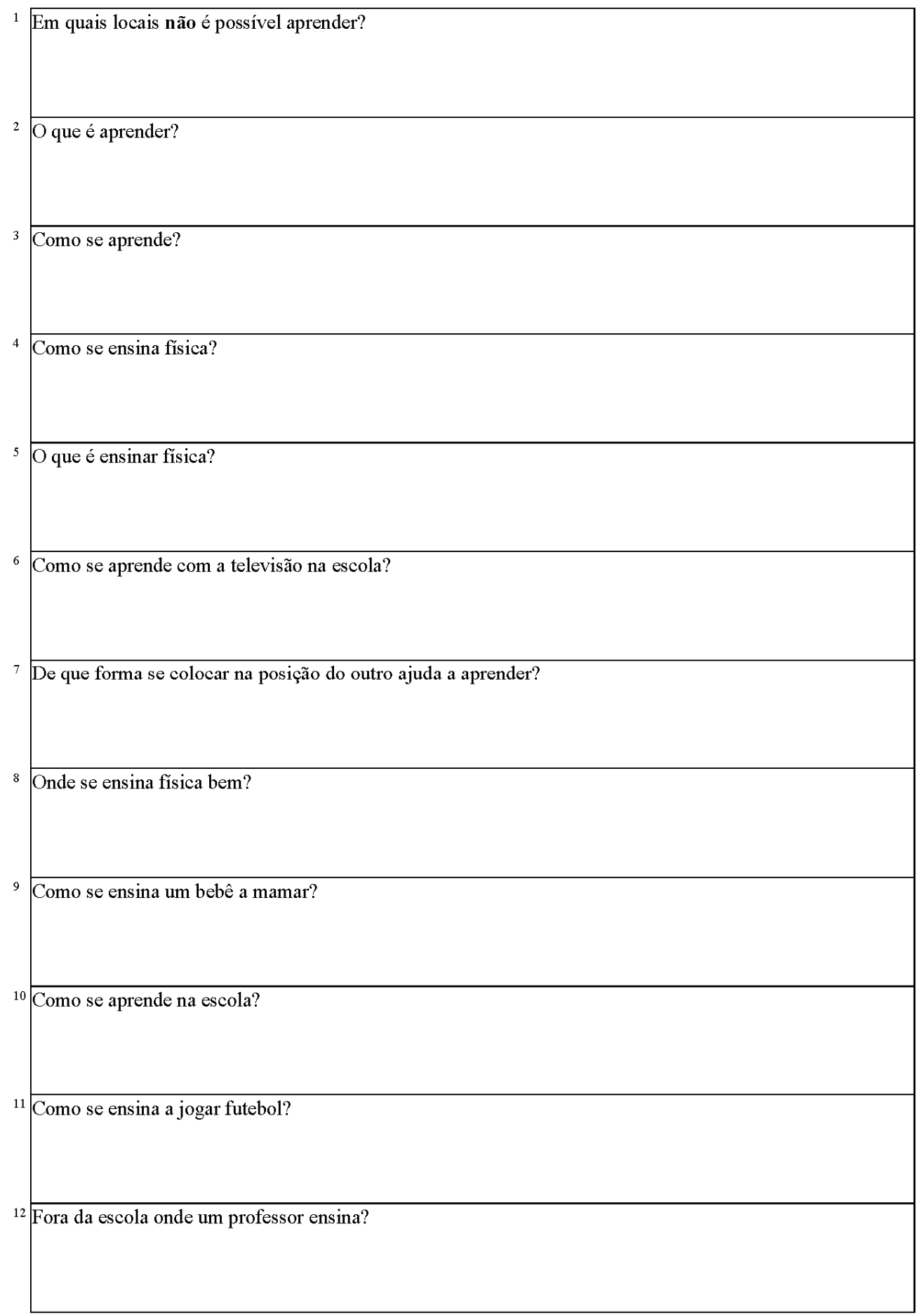


QUESTIONÁRIO W

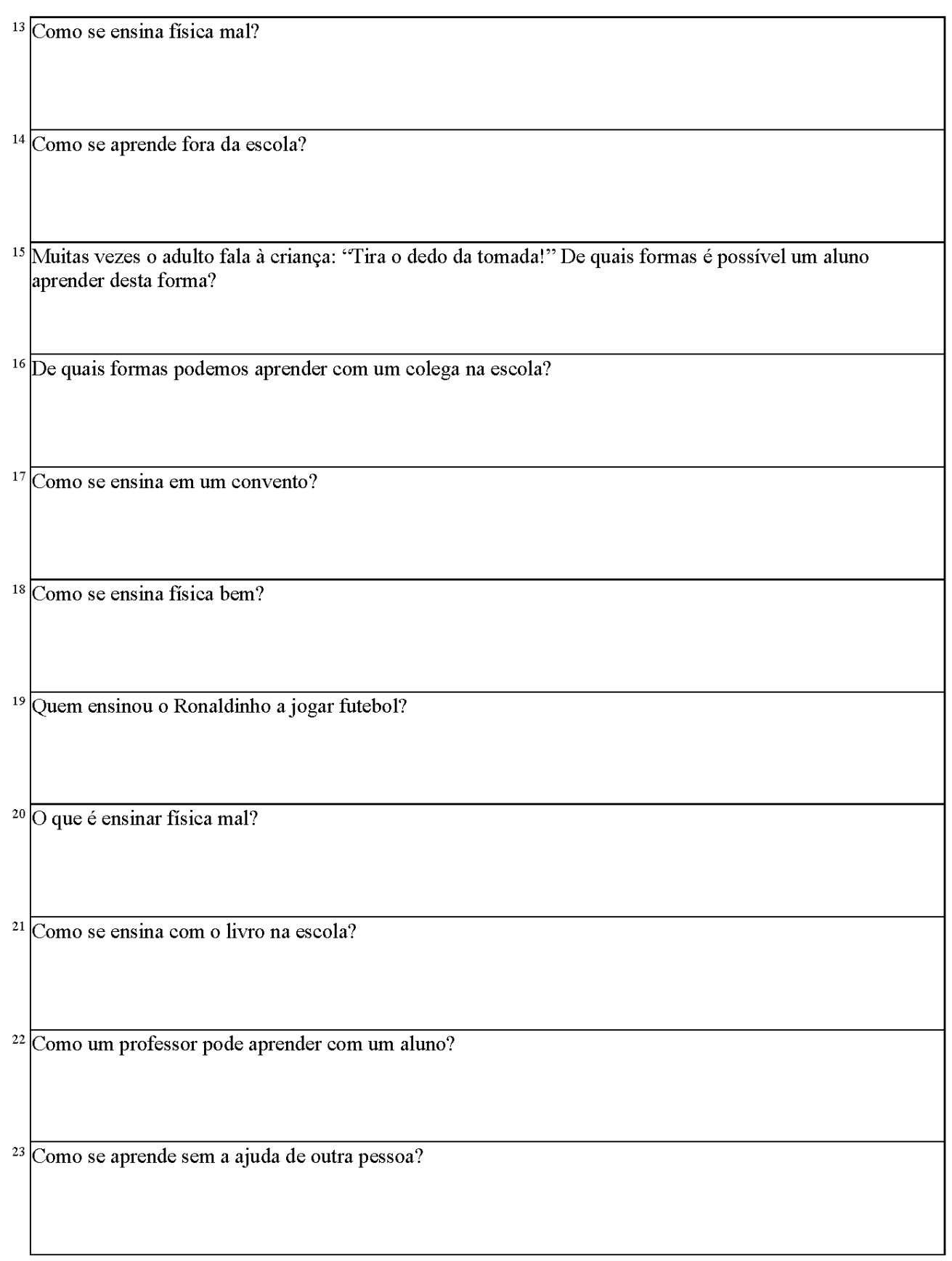


QUESTIONÁRIO X

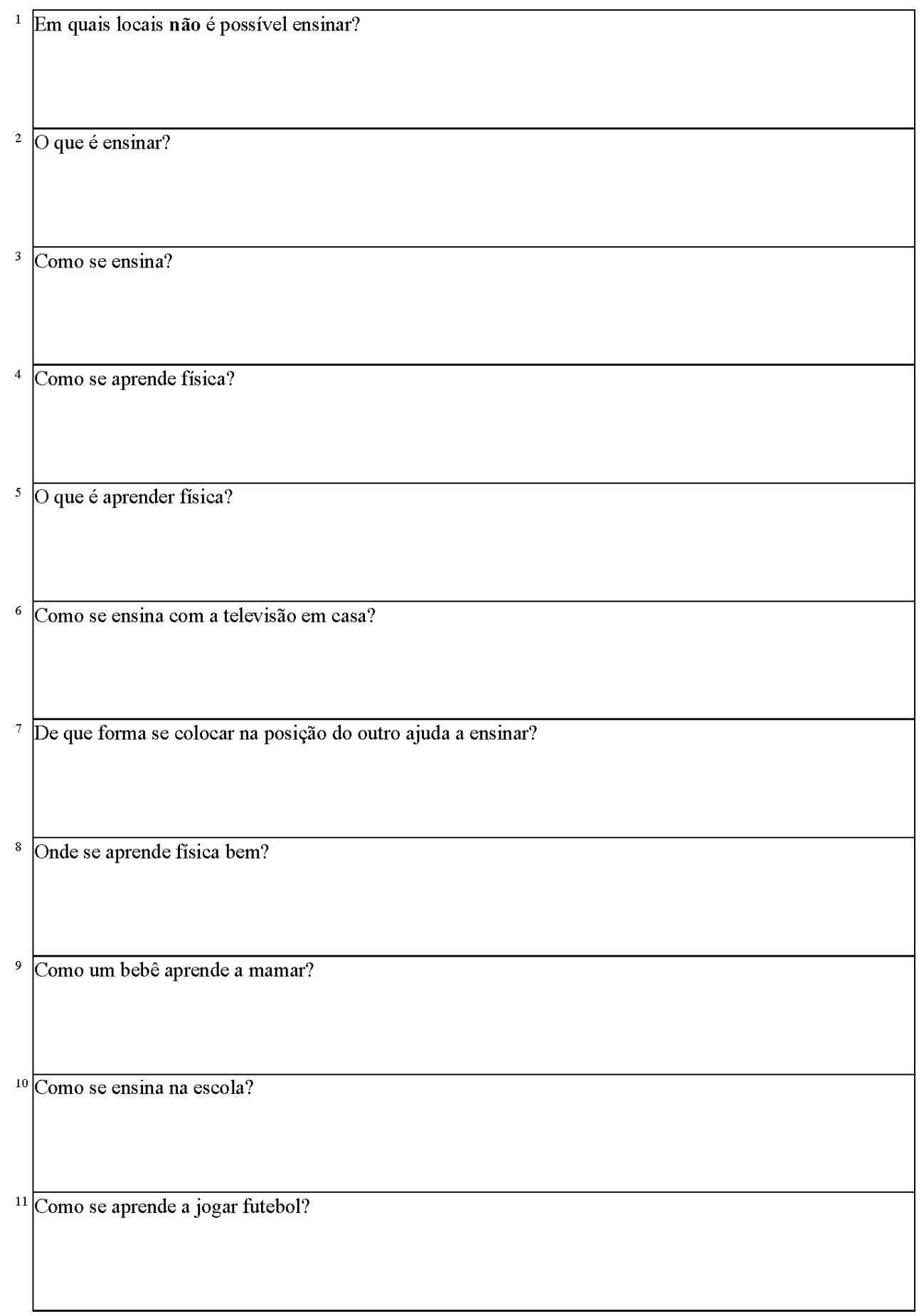




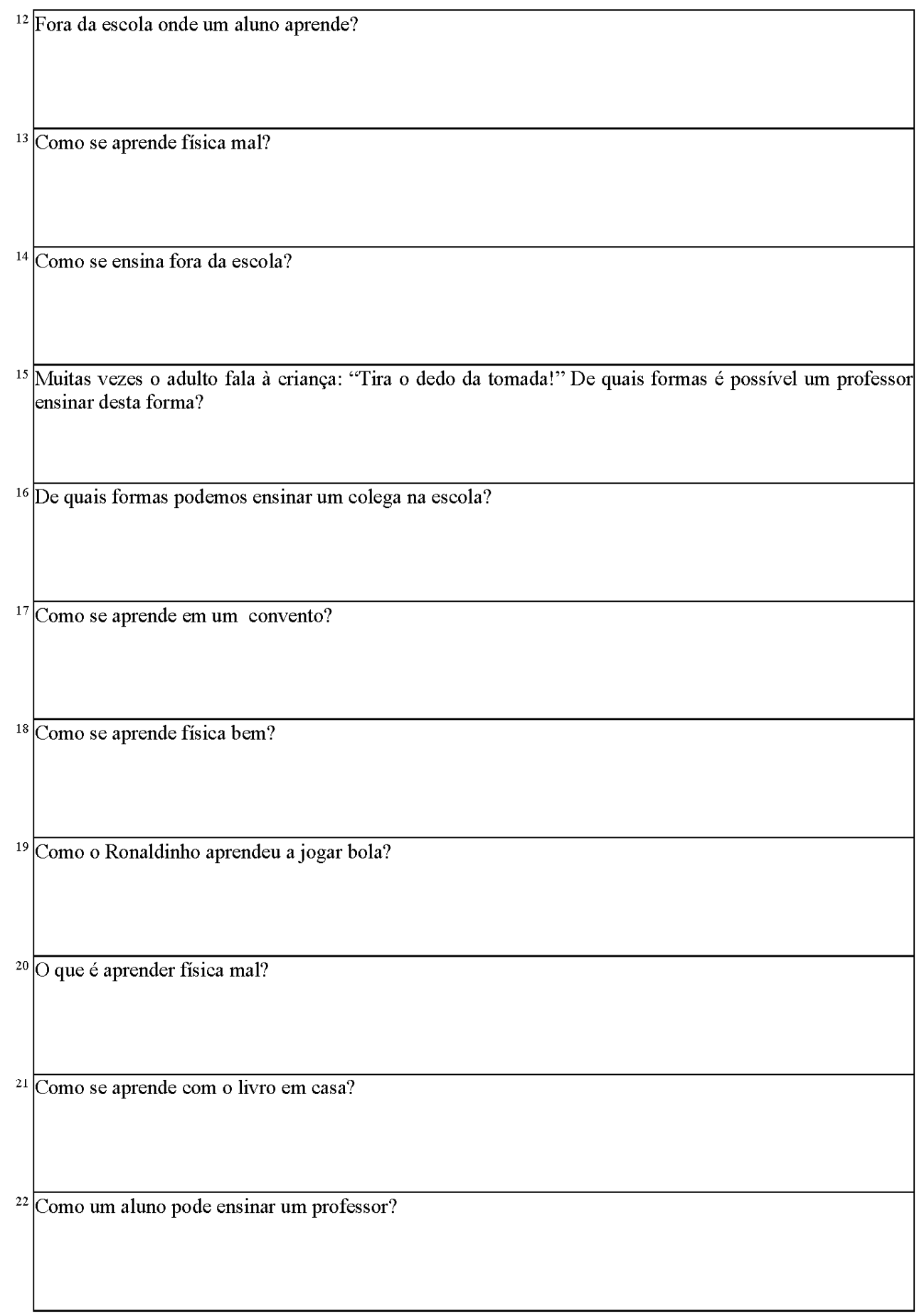


QUESTIONÁRIO Y

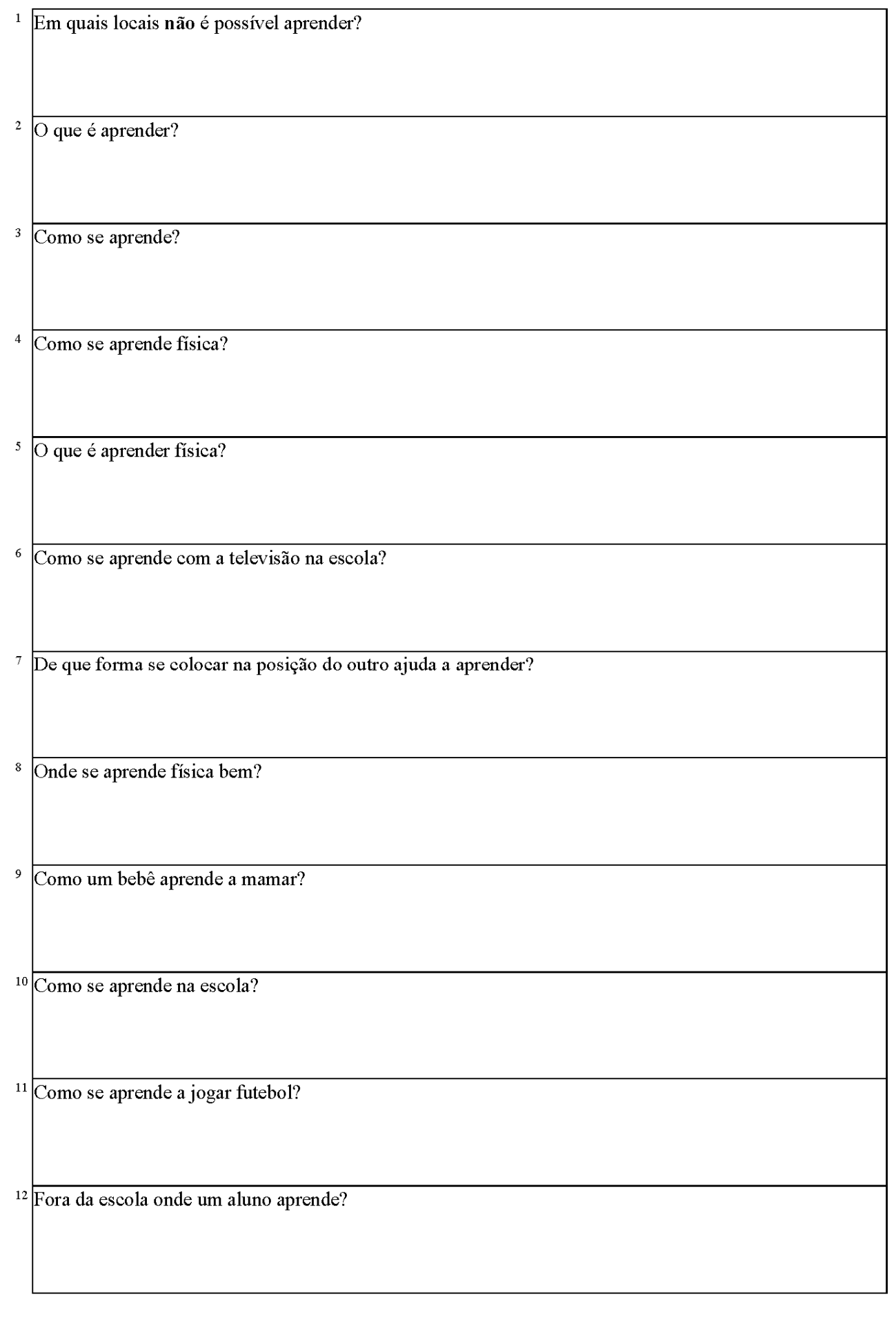




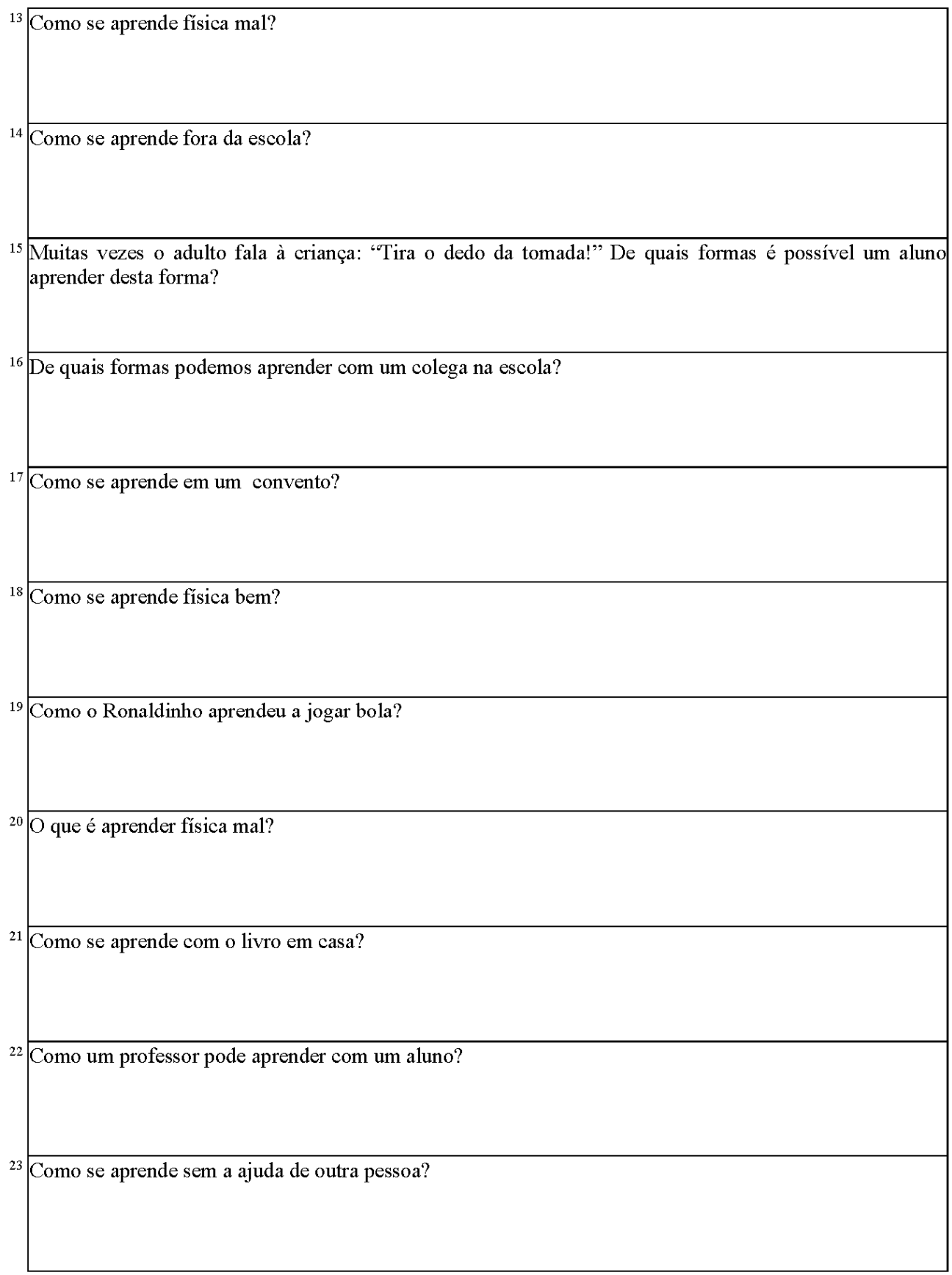


QUESTIONÁRIO Z

\begin{tabular}{|c|c|c|}
\hline & 1 & Em quais locais não é possível ensinar? \\
\hline & 2 & O que é ensinar? \\
\hline & 3 & Como se ensina? \\
\hline & 4 & Como se ensina física? \\
\hline & 5 & O que é ensinar física? \\
\hline & 6 & Como se ensina com a televisão em casa? \\
\hline & 7 & De que forma se colocar na posição do outro ajuda a ensinar? \\
\hline & 8 & Onde se ensina física bem? \\
\hline & 9 & Como se ensina um bebê a mamar? \\
\hline & 10 & Como se ensina na escola? \\
\hline & 11 & Como se ensina a jogar futebol? \\
\hline
\end{tabular}


12 Fora da escola onde um professor ensina?

13 Como se ensina física mal?

14 Como se ensina fora da escola?

15 Muitas vezes o adulto fala à criança: “Tira o dedo da tomada!" De quais formas é possível um professor ensinar desta forma?

16 De quais formas podemos ensinar um colega na escola?

17 Como se ensina em um convento?

18 Como se ensina física bem?

19 Quem ensinou o Ronaldinho a jogar futebol?

20 O que é ensinar física mal?

21 Como se ensina com o livro na escola?

22 Como um aluno pode ensinar um professor? 


\section{AO CHEGAR AO FIM, ESTAMOS DE VOLTA AO INÍCIO}

Ao chegar ao fim, torna-se impossível não agradecer novamente àqueles que fizeram e fazem parte deste texto, de minha vida complexa e simples, conectada e dependente.

Não sou capaz de externar tudo que sinto ao término desta etapa, Mas sem dúvida o que domina minha mente neste momento é:

Quando os sonhos se cruzam,

quando somos cativados pela simplicidade, quando o cativante cativa e é cativado,

quando temos coragem de lutar pelo que queremos, quando amamos-vivendo intensamente, quando aproveitamos cada segundo, quando não temos medo de partir, quando não temos medo de chegar, quando a amizade é verdadeira, quando a confiança é base das relações, quando sabemos dividir as tristezas e principalmente as alegrias, quando cremos na Felicidade, se sabemos compartilhar com quem amamos, A presença física e as barreiras da vida tornam-se apenas detalhes.

Detalhes muito ínfimos, que facilmente são transpostos pelos corações cativados e perseverantes no bem..

E sem dúvida, depois do fim...

um novo recomeço, com novas e as velhas perguntas:

O quê?

Onde?

Quando?

Por quê?

Para quê?

Como? 